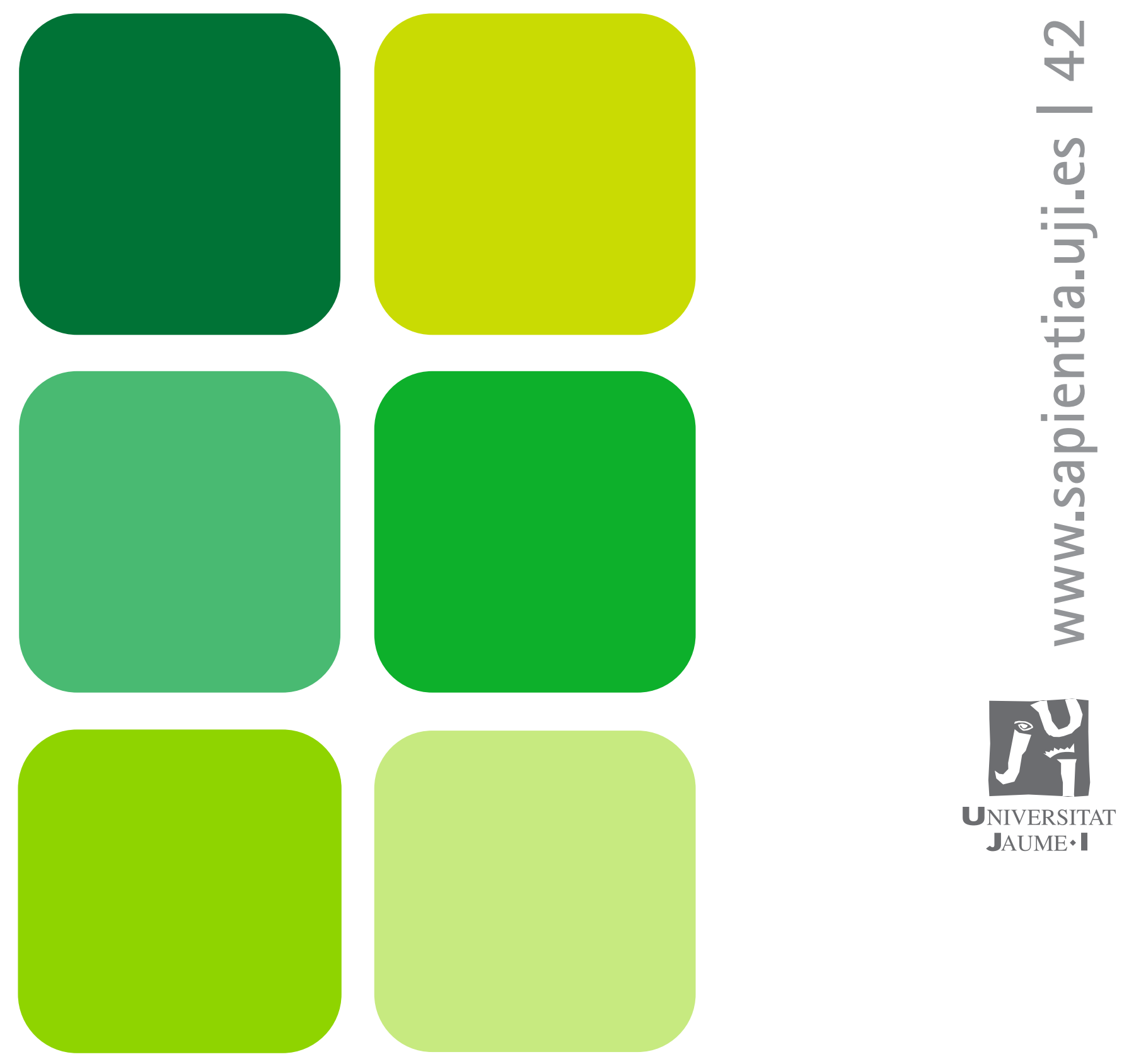

\title{
Manual de pràctiques de protecció de cultius
}

Tatiana Pina Desfilis

Mónica A. Hurtado Ruiz Josep A. Jacas Miret 


\section{Manual de pràctiques de protecció de cultius}

Tatiana Pina Desfilis

Mónica A. Hurtado Ruiz

Josep A. Jacas Miret

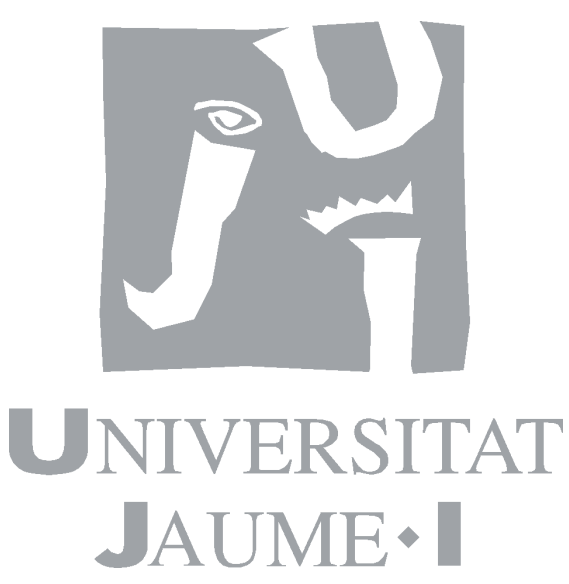

Grau en Enginyeria Agroalimentària I DEL Medi RuRAL

Codi d'assignatura AG1018 
Edita: Publicacions de la Universitat Jaume I. Servei de Comunicació i Publicacions Campus del Riu Sec. Edifici Rectorat i Serveis Centrals. 12071 Castelló de la Plana http://www.tenda.uji.es e-mail: publicacions@uji.es

Col-lecció Sapientia, 42

www.sapientia.uji.es

Primera edició, 2012

ISBN: 978-84-693-5407-0

Publicacions de la Universitat Jaume I és una editorial membre de l'UNE, cosa que en garanteix la difusió de les obres en els àmbits nacional i inter-

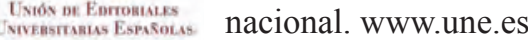

\section{(c) (1) (8)(2)}

Aquest text està subjecte a una llicència Reconeixement-NoComercial-CompartirIgual de Creative Commons, que permet copiar, distribuir i comunicar públicament l'obra sempre que especifique l'autor i el nom de la publicació i sense objectius comercials, i també permet crear obres derivades, sempre que siguen distribuïdes amb aquesta mateixa llicència.

http://creativecommons.org/licenses/by-nc-sa/2.5/es/deed.ca 


\section{ÍNDEX}

\section{PRÀCTICA 1}

Observació i identificació dels ordres d'insectes d'importància

agronòmica $\ldots \ldots \ldots \ldots \ldots \ldots \ldots \ldots \ldots \ldots \ldots \ldots \ldots \ldots \ldots \ldots \ldots \ldots$

1. Antecedents ............................... 8

1.1. Els artròpodes $i$ els insectes $\ldots \ldots \ldots \ldots \ldots \ldots \ldots \ldots \ldots \ldots$

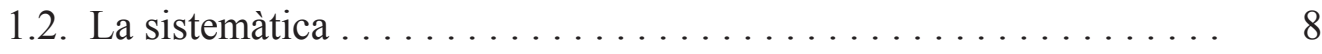

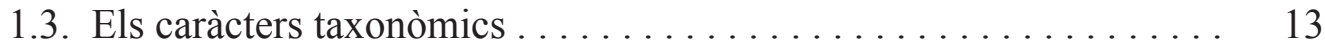

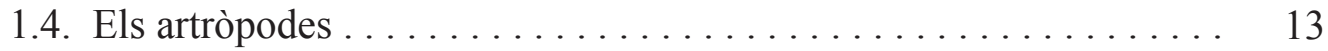

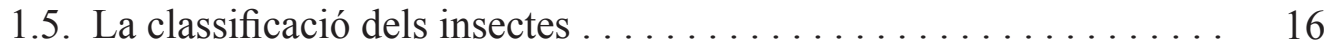

1.6. Característiques principals dels ordres d'insectes .......... 18

1.6.1. Ordre Microcoryphia i Ordre Zygentoma . . . . . . . . . . 18

1.6.2. Ordre Ephemeroptera . . . . . . . . . . . . . . . 19

1.6.3. Ordre Odonata ...................... 20

1.6.4. Ordre Orthoptera . . . . . . . . . . . . . . . . . 20

1.6.5. Ordre Grylloblattodea . . . . . . . . . . . . . . . 21

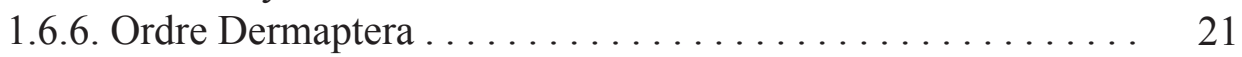

1.6.7. Ordre Plecoptera ..................... 22

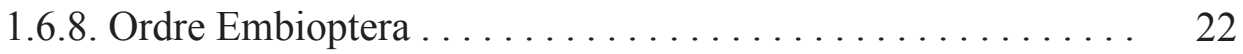

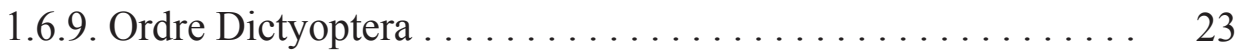

1.6.10. Ordre Isoptera . . . . . . . . . . . . . . . 24

1.6.11. Ordre Phasmida ........................ 24

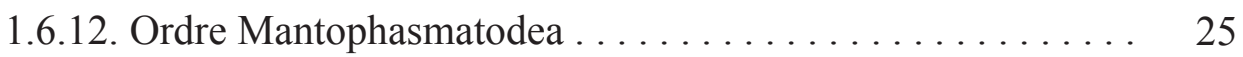

1.6.13. Ordre Zoraptera . . . . . . . . . . . . . . . . . 25

1.6.14. Ordre Psocoptera ..................... 26

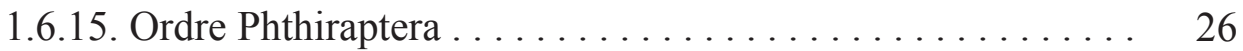

1.6.16. Ordre Hemiptera . . . . . . . . . . . . . . . . . . . . . . 27

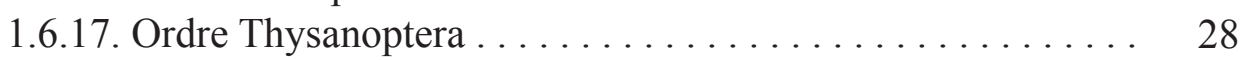

1.6.18. Ordre Mecoptera . . . . . . . . . . . . . . . . . 28

1.6.19. Ordre Lepidoptera . . . . . . . . . . . . . . . . . . 29

1.6.20. Ordre Trichoptera . . . . . . . . . . . . . . . . . . . 29

1.6.21. Ordre Diptera . . . . . . . . . . . . . . . . . . 30

1.6.22. Ordre Siphonaptera .................... 31

1.6.23. Ordre Neuroptera . . . . . . . . . . . . . . . . . . 31

1.6.24. Ordre Megaloptera . . . . . . . . . . . . . . . 31

1.6.25. Ordre Raphidioptera . . . . . . . . . . . . . . . . 32

1.6.26. Ordre Coleoptera . . . . . . . . . . . . . . . . . . . 32

1.6.27. Ordre Strepsiptera . . . . . . . . . . . . . . . . 33

1.6.28. Ordre Hymenoptera . . . . . . . . . . . . . . . 34 


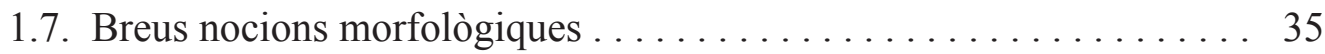

1.8. Clau dels ordres d'insectes . . . . . . . . . . . . . . . . . 39

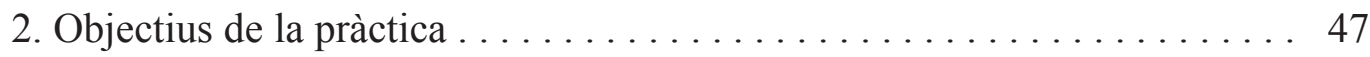

3. Desenvolupament de la pràctica $\ldots \ldots \ldots \ldots \ldots \ldots \ldots \ldots \ldots \ldots . \ldots \ldots$

3.1. Material ... . . . . . . . . . . . . . . . . . . . . 48

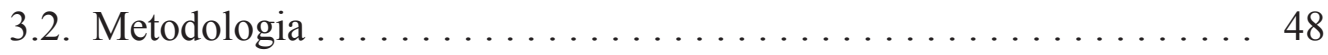

\section{PRÀCTICA 2}

Observació i identificació de les famílies de coleòpters d'importància

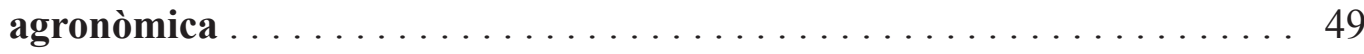

1. Antecedents . . . . . . . . . . . . . . . . . . . . . . . . . . 49

1.1. Generalitats de 1 ' ordre Coleoptera . . . . . . . . . . . . . . 49

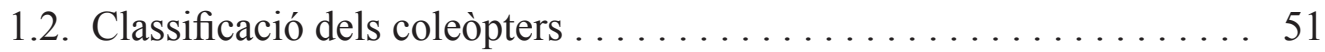

1.3. Característiques de les principals famílies d'interès agronòmic . . . 52

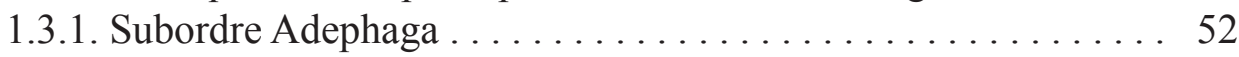

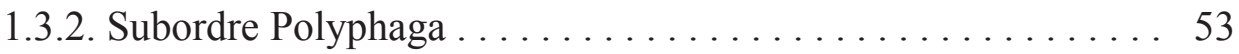

1.4. Breus nocions morfològiques dels coleòpters . . . . . . . . 60

1.5. Clau simplificada de les principals superfamílies de coleòpters

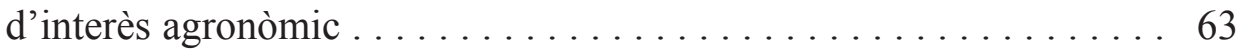

1.6. Clau simplificada de les principals famílies de coleòpters

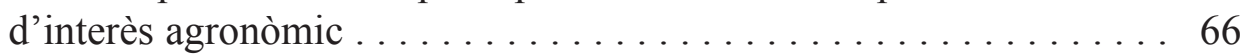

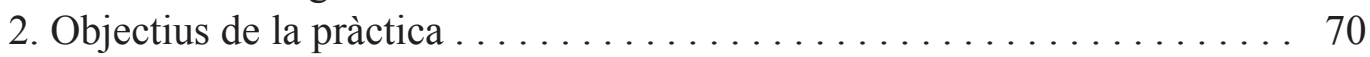

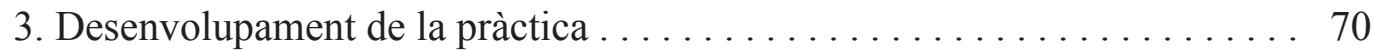

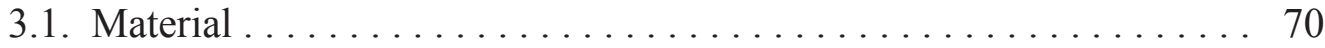

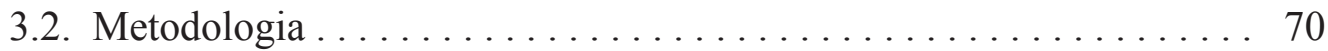

\section{PRÀCTICA 3}

Observació i identificació dels ordres i subordres d'àcars d'importància

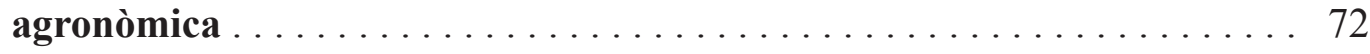

1. Antecedents . . . . . . . . . . . . . . . . . . . . 72

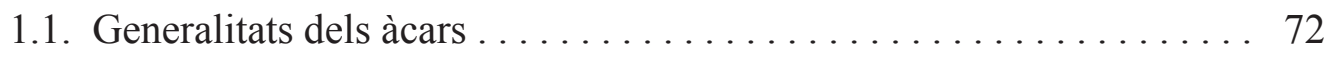

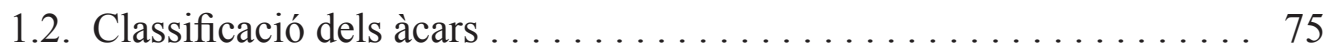

1.3. Característiques de les principals famílies d'interès agroforestal . . . . 77

1.3.1. Ordre Acariformes (Actinotrichida) . . . . . . . . . . . 77

Subordre Acaridida . . . . . . . . . . . . . . . . . . . . . . 77

Subordre Actinedida . . . . . . . . . . . . . . . . . . . . . 79

Subordre Oribatida . . . . . . . . . . . . . . . . . . . . 85

1.3.2. Ordre Parasitiformes (Anactinotrichida) . . . . . . . . . . . 86

Subordre Gamasida . . . . . . . . . . . . . . . . . . . 86

1.4. Clau simplificada dels principals ordres i superordres d'àcars . . . . 89

1.5. Vocabulari .......................... 90

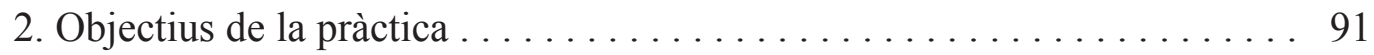

3. Desenvolupament de la pràctica . . . . . . . . . . . . . . 92

3.1. Material ............................. 92

3.2. Metodologia ........................ 92 


\section{PRÀCTICA 4}

Observació i identificació d'alguns fongs d'importància agronòmica. .

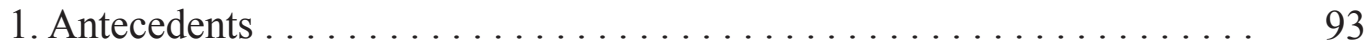

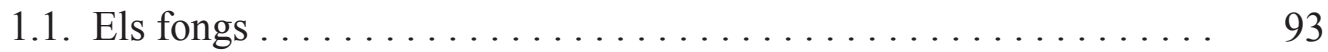

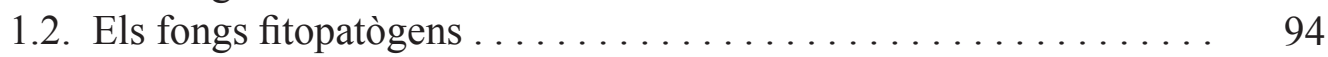

1.3. Signes i símptomes . . . . . . . . . . . . . . . . . . . . . 97

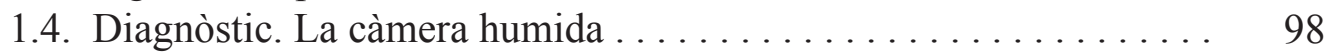

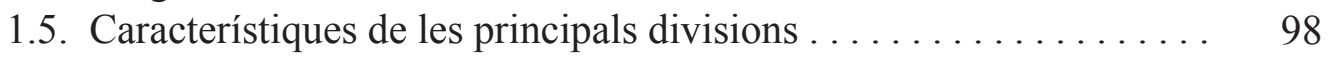

1.5.1. Divisió Oomycota: els míldius . . . . . . . . . . . . . 98

1.5.2. Divisió Basidiomycota: els rovells i els carbons . . . . . . . 100

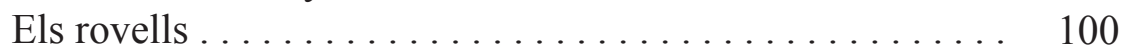

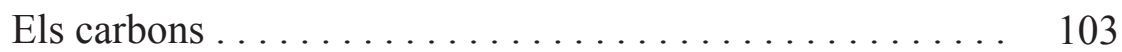

1.5.3. Divisió Ascomycota: els oïdis i la fumagina . . . . . . . . 105

Els oïdis ... . . . . . . . . . . . . . . . . . . . . . . 105

La fumagina ...................... 107

1.6. Clau simplificada per a la classificació dels fongs fitopatògens . . . 108

2. Objectius de la pràctica . . . . . . . . . . . . . . . . . . . . 109

3. Desenvolupament de la pràctica . . . . . . . . . . . . . . . . . 109

3.1. Material .................................. 109

3.2. Metodologia ............................. 109

\section{PRÀCTICA 5}

Estimació de l'eficàcia d'un tractament contra la mosca mediterrània de la fruita, Ceratitis capitata (Wiedemann) (Diptera: Tephritidae).

A. Quarantena per fred. B. Tractament insecticida . . . . . . . . . . . 111

1. Antecedents . . . . . . . . . . . . . . . . . . . 111

1.1. La mosca mediterrània de la fruita, Ceratitis capitata . . . . . . . 111

1.2. Els tractaments de quarantena . . . . . . . . . . . . . . . . 113

1.3. Quarantena per fred ... . . . . . . . . . . . . . . . . . . 114

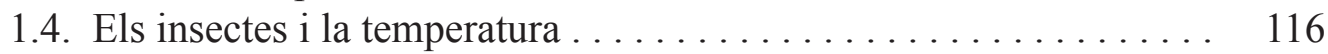

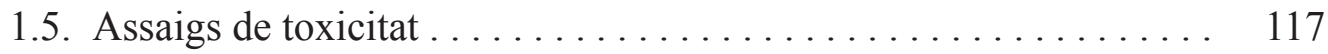

1.6. Anàlisis de la mortalitat: Relació dosi - resposta . . . . . . . . . 118

2. Objectius de les pràctiques . . . . . . . . . . . . . . . . . . . . . 119

2.1. Quarantena per fred . . . . . . . . . . . . . . . . . . . . . . 119

2.2. Assaigs de toxicitat . . . . . . . . . . . . . . . . . . . . . 120

3. Desenvolupament de les pràctiques . . . . . . . . . . . . 120

3.1. Quarantena per fred ........................ 120

3.1.1. Material . . . . . . . . . . . . . . . . . . . 120

Preparació de l'assaig .................. 120

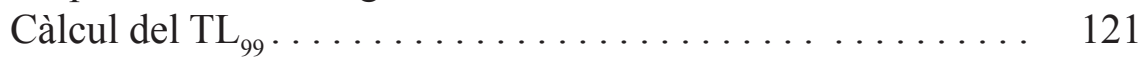

3.1.2. Metodologia ......................... 121

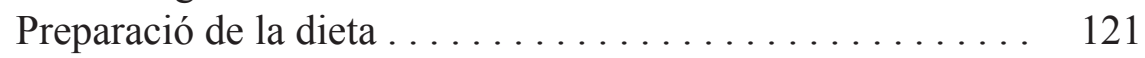

Desenvolupament de la pràctica . . . . . . . . . . . . 122

Càlcul de les eficàcies corregides . . . . . . . . . . . . 124 
Transformació a pròbits $\mathrm{i}$ càlcul del $\mathrm{TL}_{99} \ldots \ldots \ldots \ldots \ldots . \ldots \ldots$

Càlcul manual del $\mathrm{TL}_{99} \ldots \ldots \ldots \ldots \ldots \ldots \ldots \ldots \ldots \ldots \ldots$

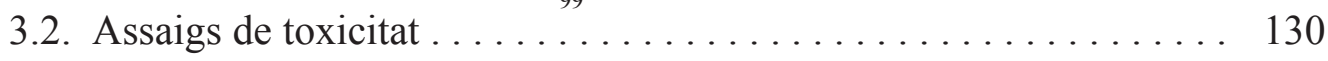

3.2.1. Material . . . . . . . . . . . . . . . . . . . . 130

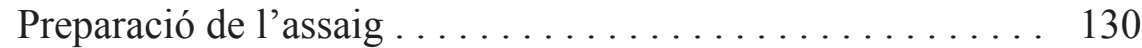

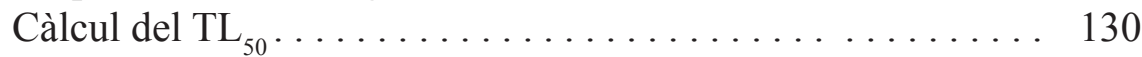

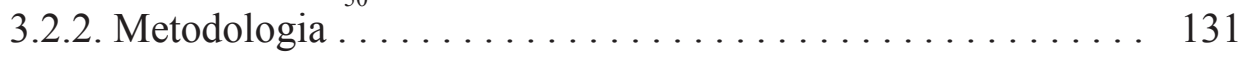

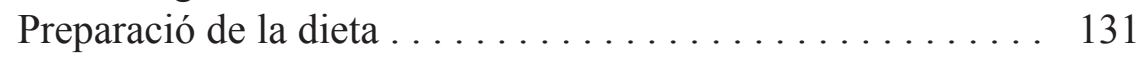

Desenvolupament de la pràctica ............... 131

\section{PRÀCTICA 6}

Utilització d'un model en protecció vegetal: Lateblight, per al míldiu de la creilla, Phytophthora infestans (Mont.) de Bary (Oomycota: Pythiaceae) . . 133

1. Antecedents . . . . . . . . . . . . . . . . . . . . . . . . . 133

1.1. Phytophthora infestans (Mont.) de Bary ............... 133

1.2. Simptomatologia ........................ 134

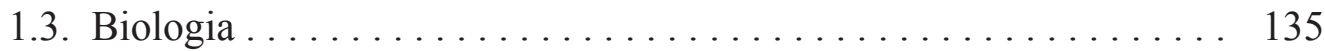

1.4. Epidemiologia ....................... 136

1.5. Control de la malaltia . . . . . . . . . . . . . . . . . . . . . 137

1.6. El model . . . . . . . . . . . . . . . . . . . . . . . . . 138

2. Objectius de la pràctica . . . . . . . . . . . . . . . 140

3. Desenvolupament de la pràctica . . . . . . . . . . . . . . . . 140

3.1. Material . . . . . . . . . . . . . . . . . . . . . . . 140

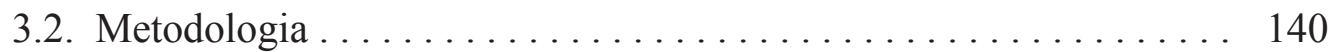

3.3. Vocabulari . . . . . . . . . . . . . . . . . . . . . . . . . 141

\section{EIXIDA 1}

Lluita autocida com a estratègia de control. Biofàbrica de mascles estèrils de Caudete de las Fuentes . . . . . . . . . . . . . . . . . . . . . . . 143

1. Antecedents . . . . . . . . . . . . . . . . . . . . . . . . . . 143

1.1. La mosca mediterrània de la fruita, Ceratitis capitata . . . . . . . . 143

1.2. Control de la mosca mediterrània de la fruita . . . . . . . . . . . . 144

1.3. Lluita autocida o Tècnica de l'Insecte Estèril (TIE) . . . . . . . . . . . . 144

1.4. Biofäbrica de mascles estèrils a Caudete de las Fuentes . . . . . . . . . 145

Cria massiva d'insectes . . . . . . . . . . . . . . . . . . . . . . 146

Evolució de les pupes . . . . . . . . . . . . . . . . . . . . . . . . . 149

Alliberament dels adults . . . . . . . . . . . . . . . . . . . . . 149

Seguiment de les poblacions i verificació de l'èxit del programa . . . 150

2. Objectius de la pràctica . . . . . . . . . . . . . . . . 150

3. Desenvolupament de la pràctica . . . . . . . . . . . . . . 151

3.1. Material .......................... 151

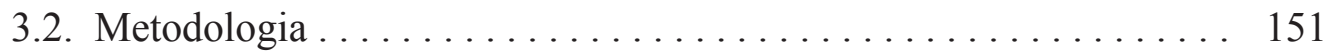




\section{EIXIDA 2}

Control biològic augmentatiu. Insectari d'Almassora de la Conselleria

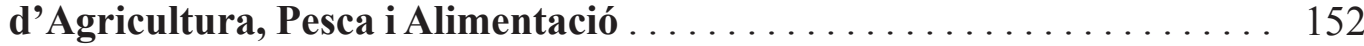

1. Antecedents . . . . . . . . . . . . . . . . . . . . 152

1.1. Conceptes ............................ 152

1.2. Tipus de control biològic . . . . . . . . . . . . . . . . . 154

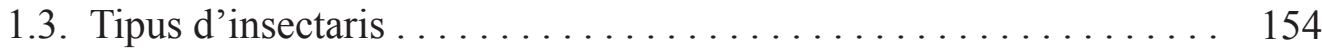

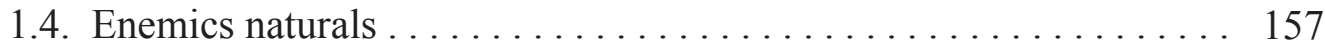

1.5. Cria en massa . . . . . . . . . . . . . . . . . . . . . . . . . . . . . 159

1.6. Organismes que es crien a l'insectari d'Almassora . . . . . . . . . . 161

1.6.1. Cotonet, Planococcus citri . . . . . . . . . . . . . . . 162

Cria del cotonet, Planococcus citri . . . . . . . . . . . 162

Cria del parasitoide Leptomastix dactylopii . . . . . . . . . . . 164

Cria del depredador Cryptolaemus montrouzieri . . . . . . . 165

1.6.2. Cotxinilla acanalada, Icerya purchasi . . . . . . . . . . . 166

Cria de la cotxinilla acanalada, Icerya purchasi . . . . . . . 166

Cria del depredador Rodolia cardinalis . . . . . . . . . . 167

1.6.3. Poll roig de Califòrnia, Aonidiella aurantii . . . . . . . . . 168

Cria de les cotxinilles Aonidiella aurantii i Aspidiotus nerii en carabassa . . . . . . . . . . . . . . . . . . . . . . . . . . . . . 169

Cria de la cotxinilla Aonidiella aurantii en llima . . . . . . . 171

Cria dels parasitoides . . . . . . . . . . . . . . . . 172

Cria del depredador Rhyzobius lophantae . . . . . . . . . 174

2. Objectius de la pràctica . . . . . . . . . . . . . . . . . . . 175

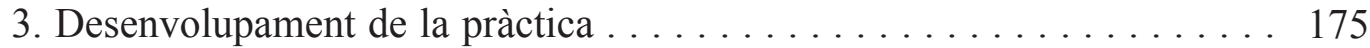

3.1. Material . . . . . . . . . . . . . . . . . . . . . . . . . . 175

3.2. Metodologia ....................... 175

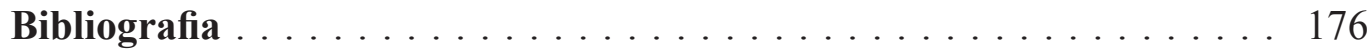




\section{PRÀCTICA 1}

\section{Observació i identificació dels ordres d'insectes d'importància agronòmica}

\section{Antecedents}

\subsection{Els artròpodes i els insectes}

La diversitat del món animal és impressionant. S'estima que hi ha entre un i sis milions d'espècies animals, de les quals més del $85 \%$ són artròpodes. Etimològicament la paraula Arthropoda prové del grec (árthron 'articulació' i poús 'peu') i significa 'tenir potes articulades'. El terme artròpode va ser emprat per primera vegada per Siebold i Stannius el 1848 (Selfa i Pujade-Villar, 2002) per definir un conjunt d'individus extraordinàriament diversificats i d'un èxit evolutiu sense precedents. Entre els artròpodes, més del 90\% són insectes (Davies, 1991), els quals formen el grup animal més gran que es coneix. Actualment hi ha entre vuit-centes mil i un milió d'espècies d'insectes descrites (Margulis i Schwartz, 1985; Davies 1991; Chapman, 2009), però es pensa que pot haver-n'hi tantes o més per descobrir -algunes estimacions ronden els cinc milions d'espècies (Chapman, 2009)-. Si aquesta immensa quantitat d'espècies la multiplicàrem pel nombre d'individus que componen les poblacions d'insectes, la quantitat total d'insectes sobre la Terra apareixeria com una xifra inimaginable.

Atesa aquesta gran variabilitat entre els insectes, resulta imprescindible per estudiar-los el fet d'ordenar-los o classificar-los de forma sistemàtica. En aquesta pràctica veurem els principals ordres en què es classifiquen els insectes, aprendrem a identificar-los i destacarem aquells d'importància agronòmica perquè es tracta d'una espècie plaga o d'un enemic natural.

\subsection{La sistemàtica}

Anomenem sistemàtica (de la paraula grega llatinitzada sistema) l'estudi científic de les classes i la diversitat d'organismes existents i de les relacions que estableixen entre si. La sistemàtica inclou la classificació, la taxonomia i la identificació (o determinació). La classificació és l'ordenació dels organismes en grups (tàxons) basant-se en les seues relacions; la identificació és el procés pel qual s'assignen individus als grups o classes prèviament establerts, mentre que la taxonomia és l'estudi teòric de la classificació, cosa que n'inclou bases, principis, procediments i regles (Viñuela et al., 1992; Gillott, 2005). En alguns llocs, la paraula taxonomia és emprada incorrectament com a sinònim de sistemàtica i classificació com a sinònim d'identificació. 
La sistemàtica dels insectes sembla que té l'origen en Aristòtil (384-322 aC), que va crear la subdivisió Entoma dins dels Anaima (animals sense sang roja o invertebrats). Els Entoma incloïen aquelles espècies que tenien el cos segmentat, és a dir, els artròpodes actuals, a excepció dels crustacis (Llorente Bousquets, 1990).

Dels seus escrits es pot deduir que Aristòtil va adonar-se de l'existència d'insectes àpters i d'alats, així com de la dels dos tipus principals d'aparells bucals: el mastegador i el picador-xuclador. Però no fou fins molt més tard, entre els segles XVII i XVIII, que no es modificà aquesta classificació. Fou el suec Carl von Linné (1707-1778) qui, amb la publicació de Sistema Naturae (1735-1770), va posar les bases de la sistemàtica moderna fins al punt que la desena edició (1758), de les tretze que en va publicar, es considera el punt d'inici de la nomenclatura zoològica. En aquesta obra el naturalista classificà la natura dins d'una jerarquia formada per tres regnes: el regne animal (Regnum Animale), el regne vegetal (Regnum Vegetabile) i el regne mineral (Regnum Lapideum). Va subdividir posteriorment el regnes en classes, les classes en ordres, els ordres en gèneres i els gèneres en espècies. En aquesta obra va popularitzar la nomenclatura binomial, ja desenvolupada 200 anys abans, en emprar-la profusament al llarg de la seua obra per descriure espècies vegetals, animals i fins i tot minerals. D'aquesta manera cada planta, animal o pedra constava d'un nom format per un nom genèric (el gènere) seguit d'un epítet específic (l'espècie), i tots dos en llatí o llatinitzats.

Linné va reconèixer set ordres d'insectes basant-se exclusivament en la morfologia de les ales (Gillott, 2005):

- Aptera (= sense ales, de pteron, 'ala' en grec),

- Neuroptera (= ales amb nombroses nerviacions, del grec neuron, 'nervi' i pteron, 'ala'),

- Coleoptera (= ales endurides que formen un estoig: els èlitres, del grec koleos, 'estoig' i pteron, 'ala'),

- Hemiptera (= ales de consistència no homogènia: els hemèlitres, del grec hemi, 'mitja' i pteron, 'ala'),

- Lepidoptera (= ales cobertes d'escates, del grec lepis, 'escates' i pteron, 'ala'),

- Diptera (= un sol parell d'ales, del grec di, 'dos' i pteron, 'ala'),

- Hymenoptera (= ales membranoses, del grec hymen, 'membrana' i pteron, 'ala').

D’aquests ordres «primitius», els tres últims s'han conservat gairebé inalterats fins als nostres dies.

Va ser a finals del segle XIX quan Brauer (1885) va establir els grans grups en què es divideix la classe Insecta: els Apterygogenea i els Pterygogenea. La primera subdivisió inclou els insectes més primitius, tots ells àpters. L'altra inclou els insectes alats, encara que alguns hagen perdut les ales secundàriament (per exemple, la majoria de les formigues). Posteriorment, el 1888, Lang va proposar substituir aquests dos termes per Apterygota i Pterygota, vocables que encara es mantenen. Actualment, la majoria dels autors estan d'acord amb les principals divisions de 
la classe Insecta, però hi ha alguns punts controvertits, com ara establir la posició real dels Zoraptera, que presenten caràcters intermedis entre els ortopteroides $i$ els hemipteroides, o si els Grylloblattoidea han de posseir categoria d'ordre o no (Gillott, 2005).

Les divisions establertes per Linné s'han anat subdividint cada vegada més a mesura que s'han anat descobrint noves espècies. A hores d'ara les categories que s'accepten més comunament són les que figuren a la taula 1.

\begin{tabular}{|c|c|c|c|}
\hline \multicolumn{2}{|c|}{ Categories de classificació } & Terminació & Terminació \\
\hline Nivell de regne & REGNE & & \\
\hline Nivell de fílum & $\begin{array}{l}\text { FÍLUM } \\
\text { Subfílum }\end{array}$ & & \\
\hline Nivell de classe & $\begin{array}{l}\text { Superclasse } \\
\text { CLASSE } \\
\text { Subclasse } \\
\text { Infraclasse }\end{array}$ & & \\
\hline Nivell d'ordre & $\begin{array}{l}\text { Superordre } \\
\text { ORDRE } \\
\text { Subordre } \\
\text { Infraordre }\end{array}$ & & \\
\hline Nivell de família & $\begin{array}{l}\text { Superfamília } \\
\text { FAMÍLIA } \\
\text { Subfamília } \\
\text { TRIBU } \\
\text { Subtribu }\end{array}$ & $\begin{array}{l}\text { - oidea } \\
\text { - idae } \\
\text { - inae } \\
\text { - ini } \\
\text { - ina }\end{array}$ & $\begin{array}{l}\text { - oideus } \\
\text { - ids } \\
\text { - ins } \\
\text { - inis } \\
\text { - ina }\end{array}$ \\
\hline Nivell de gènere & $\begin{array}{l}\text { GÈNERE } \\
\text { Subgènere }\end{array}$ & & \\
\hline Nivell d'espècie & $\begin{array}{l}\text { ESPÈCIE } \\
\text { Subespècie }\end{array}$ & & \\
\hline $\begin{array}{l}\text { Nivell d'infrasubes- } \\
\text { pècie }\end{array}$ & $\begin{array}{l}\text { Varietat } \\
\text { Casta } \\
\text { Forma } \\
\text { Raça } \\
\text { Aberració }\end{array}$ & & \\
\hline
\end{tabular}

Taula 1. Categories acceptades normalment. En majúscules s'indiquen aquelles d'aparició obligada quan classifiquem un organisme viu

Un exemple de com funciona aquest sistema el tenim exposat a la taula $2 \mathrm{amb}$ la papallona de la col Pieris brasssicae (L.) i un dels seus principals parasitoides, el bracònid Cotesia glomerata (L.). 


\begin{tabular}{|c|c|c|}
\hline CATEGORIA & Papallona de la col & Parasitoid de la papallona de la col \\
\hline REGNE & Animalia (animals) & Animalia (animals) \\
\hline FÍLUM & Arthropoda (artròpodes) & Arthropoda (artròpodes) \\
\hline CLASSE & Insecta (insectes) & Insecta (insectes) \\
\hline ORDRE & Lepidoptera (lepidòpters) & Hymenoptera (himenòpters) \\
\hline SUPERFAMÍLIA & Papilionoidea (papilionoideus) & Ichneumonoidea (icneumonoideus) \\
\hline FAMÍLIA & Pieridae (pièrids) & Braconidae (bracònids) \\
\hline SUBFAMÍLIA & Pierinae (pièrins) & Microgastrinae (microgàstrins) \\
\hline TRIBU & Pierini (pierinis) & - \\
\hline GÈNERE & Pieris & Cotesia \\
\hline ESPÈCIE & Pieris brasssicae & Cotesia glomerata \\
\hline
\end{tabular}

Taula 2. Exemple de classificació de la papallona de la col i del seu enemic natural, l'himenòpter Cotesia glomerata. Entre parèntesis s'indica el nom comú que reben les diferents categories

Per evitar la confusió de noms de gèneres en la literatura zoològica, arran de Linné i al llarg del segle XIX, en part a causa del principi d'autoritat pel qual el nom vàlid d'una espècie era el que li atribuïa el màxim especialista en el grup, el 1842 el paleontòleg anglès Hugh Strickland (1811-1853) va promoure la formació d'un comitè d'experts per crear un codi de lleis que regularen la nomenclatura zoològica. En aquest comitè participaren personatges rellevants com Charles Darwin, Richard Owen o John Westwood. Aquest codi, conegut com a Codi de Strickland, va ser l'inici del que posteriorment es conegué com a Codi Internacional de Nomenclatura Zoològica (conegut per les seues sigles en anglès ICZN), del qual a hores d'ara tenim la quarta edició (ICZN, 1999: http://nhm.ac.uk/hosted-sites/iczn/code). L'any 2000 es va traduir a l'espanyol i des de l'any 2009 està disponible electrònicament gràcies a la col-laboració del Museu Nacional de Ciències Naturals a Madrid (www.sam.mncn.csic.es/codigo.pdf). Aquest codi té com a propòsit proporcionar la màxima universalitat i continuïtat dels noms científics dels animals, de manera que cada nom siga únic i distintiu, i a més, de manera compatible amb la llibertat dels científics per classificar els animals d'acord amb els seus criteris taxonòmics. El codi està format per articles (d'ús obligatori) i per recomanacions. Els articles estan dissenyats per capacitar els zoòlegs a arribar als noms dels tàxons que siguen correctes sota circumstàncies taxonòmiques particulars. L'ús del codi permet determinar el nom vàlid de qualsevol tàxon al qual pertanga un animal en qualsevol categoria de les jerarquies d'espècie, gènere $\mathrm{i}$ família (incloent subespècie, 
subgènere i categories del nivell de família, com són la subfamília i la tribu). El codi no regula totalment els noms dels tàxons per damunt del nivell de família (ordre, classe i fílum) i no proporciona regles per a l'ús per sota de la categoria de subespècie (varietat, aberració...), ja que no tenen entitat taxonòmica. D'altra banda, tots els noms científics es regeixen pel principi de prioritat, segons el qual el nom vàlid d'un tàxon és el nom més antic i tots els altres noms del mateix tàxon es consideren sinònims. L'himenòpter parasitoid de l'exemple, Cotesia glomerata, va rebre posteriorment altres noms, com ara Apanteles glomeratus o Microgaster glomerata, si bé el nom acceptat va ser el primer amb què es va descriure.

El codi regula, entre altres coses, el nombre de paraules que poden tenir els noms, quins noms es poden emprar, com es formen i es tracten els noms nous, com es regulen els drets d'autoria, els criteris de publicació, etc. A més, fixa aspectes tan comuns com que el gènere s'escriu sempre en majúscula inicial mentre que l'epítet específic ha d'anar sempre en minúscula inicial (error molt comú en mitjans de comunicació com ara diaris, revistes... que acostumen a posar totes dues inicials en majúscula), que l'espècie se cita amb els dos termes que han d'anar escrits en cursiva (o subratllats, si no fóra possible escriure'ls en cursiva) i, sempre que siga possible, acompanyats del nom de l'autoritat que l'ha descrita i de l'any de publicació. El fet de posar el nom de l'autor entre parèntesi, així com l'any, també està regulat pel codi, ja que no sempre cal posar-ne. El parèntesi afegeix un significat a la descripció de l'espècie i, per tant, cal estar segur de la seua presència o absència. En els exemples citats prèviament, la manera correcta d'anomenar-los seria:

\section{Pieris brassicae (Linnaeus 1758) i Cotesia glomerata (Linnaeus 1758)}

Però, per a la marieta de set punts, per exemple, el nom correcte és:

\section{Coccinella septempunctata Linnaeus 1758}

En aquest últim cas, el fet que el nom de l'autor no vaja entre parèntesi vol dir que el nom actual coincideix amb el de la descripció original, mentre que en els dos casos primers, els parèntesis indiquen que, tot i que la descripció original és la de Linné, aquestes espècies han tornat a ser descrites posteriorment per altres autoritats.

Per citar correctament les espècies, sense haver de recórrer a les claus taxonòmiques, existeixen nombroses pàgines web com ara Fauna Europaea (http://www. faunaeur.org), que és una base de dades de noms científics i distribució de tota mena d'animals terrestres i aquàtics europeus, Catalogue of Life (http://www.catalogueoflife.org (Bisby et al., 2012)), catàleg de totes les espècies d'organismes de la Terra, fruit principalment de la unió de la base de dades Species 2000 (http://www. sp2000.org) i de l'Integrated Taxonomic Information System (ITIS) (http://www.itis. gov/). L'Encyclopedia of Life (EoL) (http://www.eol.org) i la Global Biodiversity Information Facility (GBIF) (http://www.gbif.es/) empren com a eina taxonòmica dels seus portals web el Catalogue of Life.

Codis semblants es poden trobar en altres grups, com ara el Codi Internacional de Nomenclatura Botànica (acrònim en anglès, ICBN), el Codi Internacional de 
Nomenclatura de Bacteris (acrònim en anglès, ICNB) o el Comitè Internacional de Taxonomia de Virus (acrònim en anglès, ICTV).

\subsection{Els caràcters taxonòmics}

Com veurem en el transcurs de la pràctica, la identificació o determinació d'una espècie d'insecte es basa en l'observació dels anomenats caràcters taxonòmics. Un caràcter taxonòmic és qualsevol atribut d'un membre d'un tàxon que el distingeix o el pot distingir dels membres d'un altre tàxon (Mayr, 1969).

La finalitat dels caràcters és doble. D'una banda, s'utilitzen en la fase inductiva de determinació de les unitats de classificació, és a dir, en el mateix procés de classificació o ordenació dels organismes en grups, però els mateixos caràcters (normalment només uns quants) s'utilitzen en el procés d'identificació o determinació, que és l'objectiu d'aquesta pràctica. Molts caràcters taxonòmics, per exemple químics, bioquímics, fisiològics, etològics o genètics, tenen un alt valor en la classificació, però necessiten tècniques especials o són destructius, per la qual cosa són inadequats en molts casos per a la determinació.

Pràcticament qualsevol atribut d'un organisme pot tenir valor taxonòmic, però a causa de la facilitat amb què s'observen, els de tipus morfològic solen ser els preferits pels taxònoms. Aquest és el cas ja esmentat de la presència d'ales i la seua venació, o el del tipus d'aparell bucal, utilitzats en la construcció de les categories superiors, com per exemple, els ordres.

En l'actualitat, els caràcters morfològics externs continuen sent els més importants en el procés d'identificació, ja que s'hi basen la majoria de les claus per a insectes. En canvi, van adquirint més rellevància altres tipus de caràcters menys visibles, però que actuen com a factors molt eficaços d'aïllament real o potencial, com la genitàlia o la dotació cromosòmica (quan ens acostem a les últimes categories de les claus, nivell d'espècie o inferiors, principalment), o d'altres que exigeixen de l'organisme en vida, com aquells caràcters que ens proporcionen dades del comportament $\mathrm{i}$ que en alguns casos permeten distingir dues espècies morfològicament idèntiques. És, per exemple, el cas del parasitoid afelínid Encarsia perniciosi Tower, del qual existeixen dues races especialitzades, cadascuna en dos hostes diferents, ambdós d'importància agronòmica, com són el poll roig de Califòrnia, Aonidiella aurantii (Maskell), i el poll de San José, Diaspidiotus perniciosus (Comstock), espècies plaga importants dels cítrics i dels fruiters, respectivament.

\subsection{Els artròpodes}

Els artròpodes són un grup d'organismes molt diversificat, l'origen dels quals es remunta al Precambrià, fa més de 600 milions d'anys (m.a.), a partir d'organismes que recorden els anèl-lids marins. Malgrat això, no tenim evidència fòssil d'aquest grup fins al Cambrià (fa 542 m.a.), moment en què les condicions de 
la Terra permeteren la conservació dels cadàvers d'aquesta forma. En aquell moment, sabem que ja eren abundants els crustacis, els trilobits i els euriptèrids (aquests dos darrers grups ja extingits).

Existeix molta controvèrsia respecte a l'origen dels artròpodes. Alguns autors consideren que els artròpodes procedeixen d'un antecessor comú a tots ells (teoria monofilètica), d'altres parlen d'un origen diferent per als artròpodes que presenten quelícers (com ara les aranyes i els àcars) i per als que presenten mandíbules (teoria difilètica) (Moseley, 1894, en Selfa i Pujade-Villar, 2002), mentre que d'altres consideren que els artròpodes tenen un origen múltiple en què les similituds entre els diferents grups obeeixen a un procés de convergència (teoria polifilètica). La balança final de totes les teories juntament amb estudis moleculars recents pareix que apunta a un origen monofilètic dels artròpodes (Selfa i Pujade-Villar, 2002; Gillott, 2005). És a dir, el procés d'artropodització ha succeït una sola vegada al llarg de la història de la Terra.

Malgrat tota la discrepància filogenètica, tots els artròpodes presenten els trets comuns següents (Viñuela et al., 1992; Selfa i Pujade-Villar, 2002; Gillott, 2005):

- simetria bilateral;

- esquelet extern metameritzat i segmentat externament;

- apèndixs parells articulats, en un nombre variable de segments;

- exosquelet segregat per l'epidermis i format per quitina, que es renova periòdicament amb la muda, procés sota control hormonal;

- moviments en general regionals, mitjançant la inflexió dels apèndixs, en llocs no rígids del cos. Sistema muscular llis i no metamèric (musculatura visceral), o estriat i metamèric (musculatura somàtica);

- sistema nerviós central format per una doble cadena ventral amb ganglis metamèrics parells, els primers dels quals (els supraesofàgics) constitueixen el complex cerebroide o cerebral;

- sistema sensorial format per sensílies i ulls simples o compostos;

- intercanvi gasós, si no és solament tegumentari, es dóna per mitjà de brànquies en els organismes aquàtics i per tràquees d'origen divers en els organismes terrestres;

- sistema circulatori obert. Vas sanguini únic, en posició dorsal. Líquid sanguini, en general, sense pigments respiratoris;

- òrgans excretors formats en principi per nefridis modificats i secundàriament per altres mecanismes d'origen divers;

- mètodes d'alimentació diversos. Aparell digestiu tubular amb boca i anus;

- reproducció, en general, sexual, amb sistemes de complexitat variables. Rarament són hermafrodites. Són ovípars i excepcionalment ovovivípars o vivípars.

En aquest manual seguirem la classificació dels artròpodes establerta per Gillott (2005), tal com s'exposa en la figura 1. 


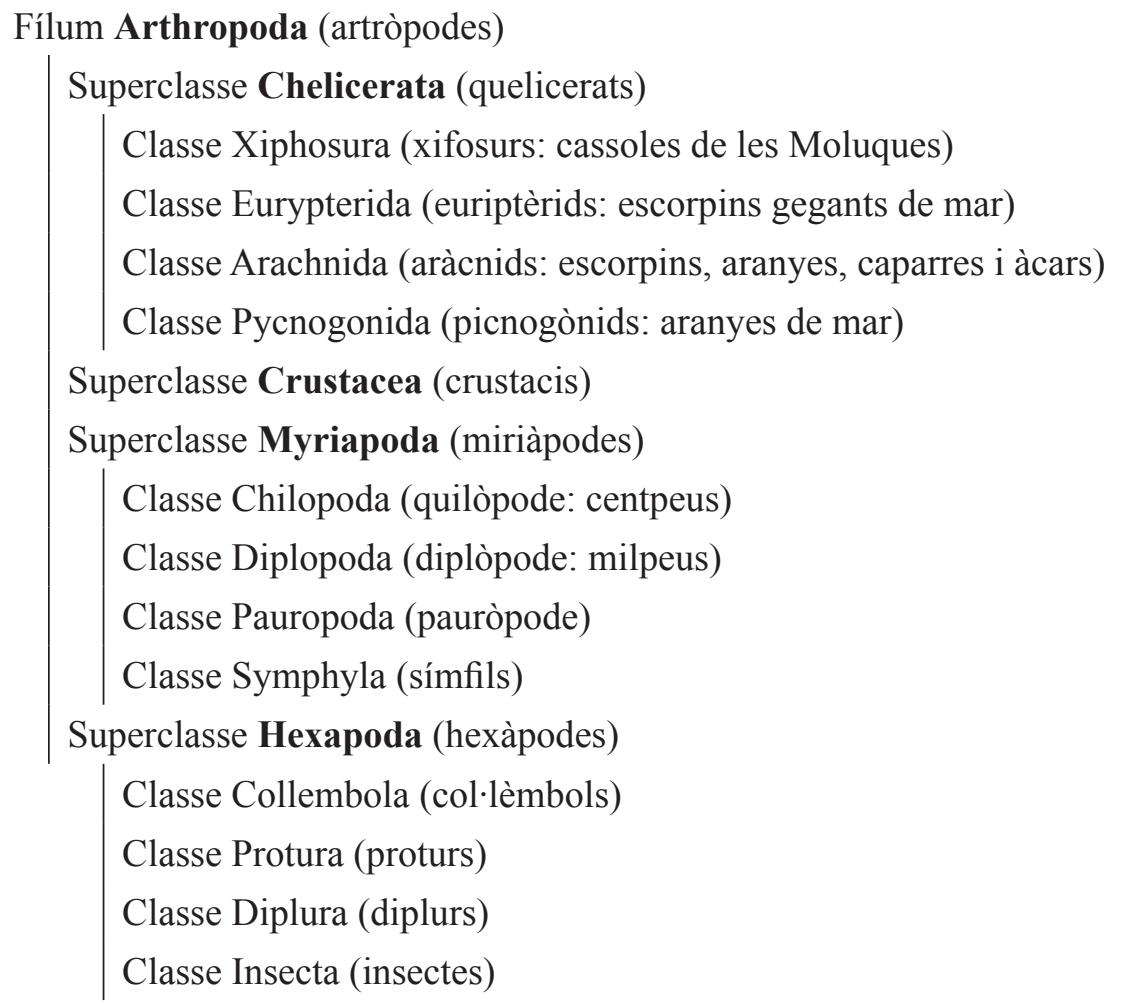

Figura 1. Classificació dels artròpodes segons Gillott (2005)

De tota aquesta classificació només els aràcnids i els insectes tenen interès agrícola. Entre els aràcnids, hi trobem les aranyes, els àcars, les caparres o els escorpins. Són espècies generalment terrestres, sense antenes, que presenten un aparell bucal en forma de quelícers i pedipalps, que només els permet d'ingerir aliment líquid. El cos està dividit en cefalotòrax i abdomen i la respiració és per pulmons $i$ tràquees. Tenen quatre parells de potes (les formes juvenils en tenen tres $i$, excepcionalment, els àcars eriòfids només dues). Hi ha moltes espècies depredadores (àcars fitoseids, aranyes), així com espècies plaga (àcars tetraníquids, eriòfids, tarsonèmids, etc.). D'aquest grup, $i$ en concret de la subclasse Acari (principal subclasse dins de la classe Arachnida amb interès agrícola), en parlarem en la tercera pràctica.

Quant als insectes, engloben moltes espècies com ara llagostes, mosques, papallones, vespes, escarabats, etc. N'hi ha tant de terrestres com d'aquàtics, i sempre tenen un parell d'antenes i tres parells de potes. Tenen el cos dividit en cap, tòrax i abdomen, i solen respirar per tràquees. S'alimenten tant de líquids com de sòlids i presenten una metamorfosi més o menys complicada. Els insectes tenen un enorme interès agrícola, ja que hi ha moltes espècies plaga, però també n'hi ha d'útils (pol-linitzadors i enemics naturals, principalment), tal com veurem més endavant.

A la taula 3 es presenta una clau taxonòmica molt simplificada per poder separar els adults de les superclasses d'artròpodes. 


\begin{tabular}{|l|ll|}
\hline 1. & $\begin{array}{l}\text { Sense antenes ni mandíbules, amb quelícers i generalment } \\
\text { amb quatre parells de potes. }\end{array}$ & $\begin{array}{l}\text { Chelicerata } \\
\text { (Cl. Arachnida) }\end{array}$ \\
Amb antenes. & 2 \\
\hline 2. & $\begin{array}{l}\text { Dos parells d'antenes (de vegades només un). Cinc pa- } \\
\text { rells de potes com a mínim. Vida aquàtica o en llocs molt } \\
\text { humits. }\end{array}$ & Crustacea \\
Un únic parell d'antenes. & $\begin{array}{l}\text { Tres parells de potes. Cos dividit en tres tagmes (cap, tòrax } \\
\text { i abdomen). }\end{array}$ & Hexapoda \\
& $\begin{array}{l}\text { Més de 7 parells de potes. Cos allargat format pel cap i un } \\
\text { nombre variable de segments iguals, excepte l'últim. }\end{array}$ & Myriapoda \\
\hline
\end{tabular}

Taula 3. Clau taxonòmica simplificada del fílum Arthropoda

\subsection{La classificació dels insectes}

La classificació dels insectes també ha patit nombrosos canvis, amb l'aparició i la desaparició d'ordres com, per exemple, el Microcoryphia i el Zygentoma, que abans s'agrupaven sota l'ordre dels tisanurs, o l'Heteroptera i l'Homoptera, que actualment passen a ser subordres dins de l'ordre dels hemípters. En aquest treball, i d'acord amb el que hem fet per als artròpodes, adoptem la classificació seguida per Gillott (2005). Seguint aquest esquema, la classe Insecta es divideix en els tàxons que s'indiquen en la figura 2.

\section{Fílum Arthropoda \\ Superclasse Hexapoda \\ Classe Insecta}

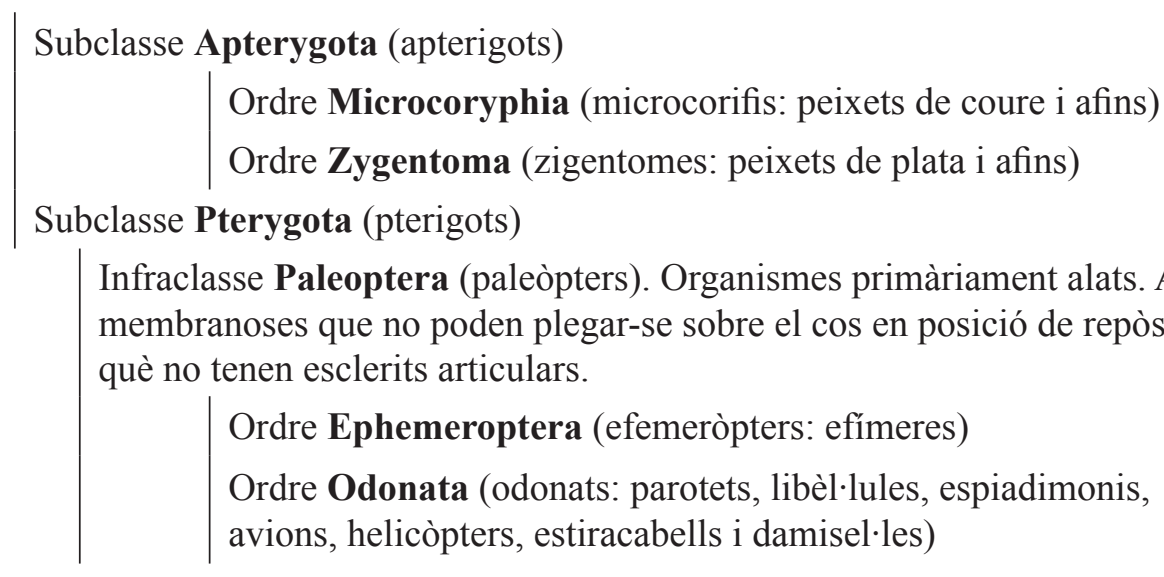


Infraclasse Neoptera (neòpters). Organismes que, en repòs, pleguen les ales sobre el cos perquè estan dotades d'esclerits articulars.

Divisió Polyneoptera (polineòpters. Ordres ortopteroides): aparell bucal mastegador, metamorfosi senzilla.

Ordre Orthoptera (ortòpters: grills, llagostes, cadells, saltamartins, pantiganes, someretes i afins)

Ordre Grylloblattodea (grilloblatodeus)

Ordre Dermaptera (dermàpters: tisoretes i afins)

Ordre Plecoptera (plecòpters: perles, mosques de les pedres i afins)

Ordre Embioptera (embiòpters: teixidors)

Ordre Dictyoptera (dictiòpters. Subordre Blattodea: cuques molles, escarabats de cuina, panereta i paneroles. Subordre Mantodea: pregadéus i voltacampanes)

Ordre Isoptera (isòpters: tèrmits o formigues blanques)

Ordre Phasmida (fàsmids: cavalls de faves i bastons)

Ordre Mantophasmatodea (mantofasmatodeus: gladiadors)

Ordre Zoraptera (zoràpters)

Divisió Paraneoptera (paraneòpters. Ordres hemipteroides): aparell bucal picador-xuclador, metamorfosi senzilla.

Ordre Psocoptera (psocòpters: polls dels llibres i afins)

Ordre Phthiraptera (ftiràpters: polls de l'aviram i afins -mal-

lòfags i anoplurs-)

Ordre Hemiptera (hemípters. Subordre Homoptera: cigales, pasteretes i pugons. Subordre Heteroptera: bernats, pudents i xinxes)

Ordre Thysanoptera (tisanòpters: trips)

Divisió Oligoneoptera (oligoneòpters. Ordres endopterigots): aparells bucals diversos, metamorfosi complicada.

Ordre Mecoptera (mecòpters: mosques escorpí i afins)

Ordre Lepidoptera (lepidòpters: papallones, palometes, falenes, arnes, borinots i tinyes)

Ordre Trichoptera (tricòpters: frigànies)

Ordre Diptera (dípters: mosques, moscardes, tàvecs i mosquits)

Ordre Siphonaptera (sifonàpters: puces)

Ordre Neuroptera (neuròpters: crisopes, reis de formigues, formigues lleó i afins)

Ordre Megaloptera (megalòpters: siàlids)

Ordre Raphidioptera (rafidiòpters: mosques serp)

Ordre Coleoptera (coleòpters: escarabats)

Ordre Strepsiptera (estrepsípters)

Ordre Hymenoptera (himenòpters: vespes, abelles i formigues)

Figura 2. Classificació dels insectes segons Gillott (2005) 
Els insectes apterigots, igual que els diplurs, els col·lèmbols i els proturs, són formes primitivament àpteres que no experimenten una metamorfosi en el seu desenvolupament o aquesta és molt lleu. En general, muden diverses vegades després d'arribar a la maduresa sexual, i els adults presenten un parell d'apèndixs pregenitals extra. Per contra, els adults pterigots són alats o secundàriament àpters $(\mathrm{p}$. ex. les formigues) i presenten una metamorfosi variada, més o menys complicada, on els adults no muden ni tampoc presenten apèndixs pregenitals. Generalment no tenen apèndixs abdominals (Richards i Davis, 1984).

D'altra banda, les infraclasses Paleoptera i Neoptera, a excepció de la divisió Oligoneoptera, pertanyen a la secció o grup dels exopterigots, els quals tenen metamorfosi senzilla i incompleta (hemimetàbols). En aquests no sol existir intermuda pupal, el desenvolupament alar és extern i les formes immadures (conegudes com a nimfes) s'assemblen als adults tant en estructura com en hàbits. La divisió Oligoneoptera s'inclou en el grup dels endopterigots, on la metamorfosi és completa (holometàbola), i va acompanyada d'una intermuda pupal (l'estat pupal). Les ales es desenvolupen internament $i$ les formes immadures (larves) presenten estructures i hàbits diferents dels adults (Richards i Davis, 1984).

Els hexàpodes insectes es caracteritzen pel fet de tenir el cos dividit en tres regions o tagmes (cap, tòrax i abdomen), amb apèndixs uniramis (tres d'aquests locomotors i localitzats al tòrax) i dos parells d'ales, que es poden perdre secundàriament o bé transformar-se en estructures protectores. El tegument presenta gran varietat de formacions i patrons de coloració. La musculatura esquelètica apendicular és la més important de tota la dotació muscular corporal. Posseeixen quasi sempre ulls compostos i ocels. A l'aparell digestiu es diferencia una membrana peritròfica i l'excreció és mitjançat tubs de Malpighi. L'aparell circulatori és simplificat i tancat per la part posterior. L'intercanvi gasós és fonamentalment traqueal. En general les gònades són parelles i el gonòpor, únic. Freqüentment s'hi observa un dimorfisme sexual acusat, que es manifesta en la forma, la mida i el color del cos.

\subsection{Característiques principals dels ordres d'insectes}

A continuació, i abans d'entrar a emprar la clau taxonòmica, veurem algunes característiques d'aquests ordres.

\subsubsection{Ordre Microcoryphia (= cap menut) i Ordre Zygentoma (= segments units)}

Aquests dos ordres inclouen algunes de les espècies d'insectes més antigues descrites (figura 3). Anteriorment s'agrupaven en l'ordre Thysanura (= thysanus, 'serrell' i oura, 'cua'). Els microcorifis es coneixen com a peixets de coure i els zigentomes com a peixets de plata, respectivament. Són granívors, omnívors i, alguns, fitòfags però sense importància agroforestal. Viuen confinats en llocs humits i tenen activitat nocturna. A les cases són freqüents les espècies Lepisma saccharina 
L. i Thermobia domestica (Packard), que, en alguns casos ocasionen danys als aliments amb midó però fonamentalment als llibres. Són temuts pels col·leccionistes de llibres de vell, els bibliòfils i els bibliotecaris.
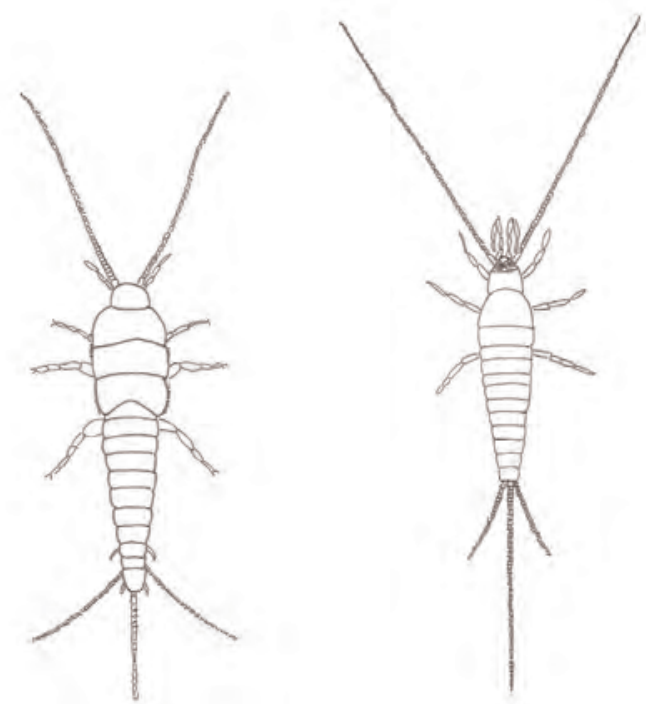

Figura 3. Aspecte d'un representant de l'ordre Microcoryphia (Petrobius maritimus (Leach)) (esquerra) i de l'ordre Zygentoma (Lepisma saccharina) (dreta). Adaptat de Richard i Davis (1984)

\subsubsection{Ordre Ephemeroptera (= ales que viuen un dia)}

El nom fa al·lusió a la vida efímera dels adults, que en alguns casos és d'hores, enfront de les nimfes, que poden viure fins a tres anys. Es troben associats a llocs amb aigua, on les nimfes serveixen d'aliment per als peixos. Els pescadors de riu acostumen a imitar aquests insectes amb els hams quan pesquen amb «mosquit». Es caracteritzen pel fet de tenir unes ales amb nombroses venes, dos llargs cercs terminals, i en ocasions, un llarg filament caudal o paracerc (figura 4). No tenen importància agrícola.
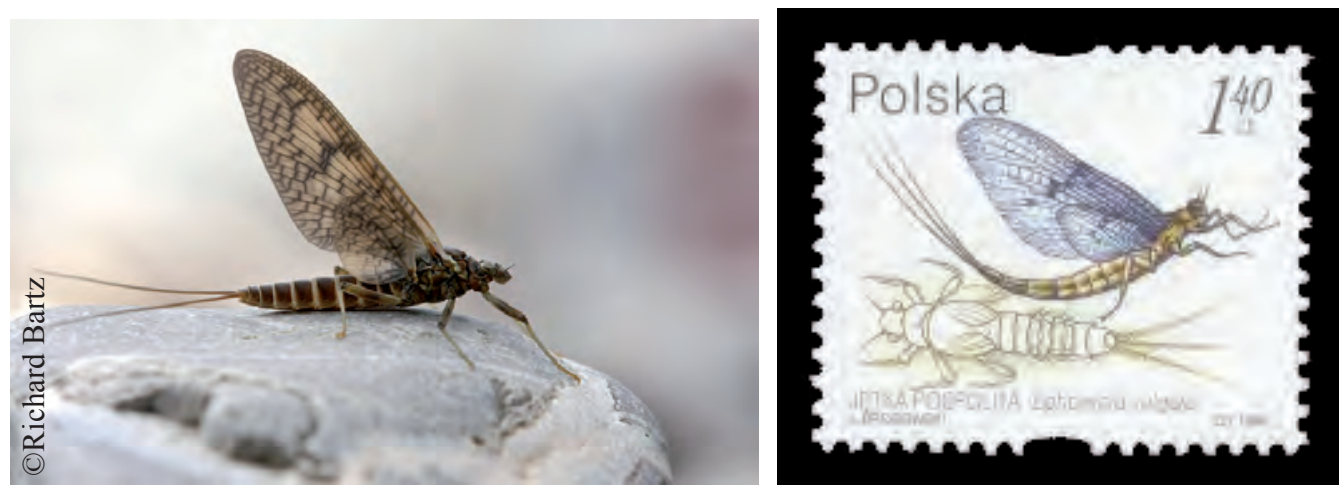

Figura 4. Aspecte dels efímers. Al segell (dreta) es pot observar també la morfologia de les nimfes d'aquest ordre 


\subsubsection{Ordre Odonata (odous $=$ 'dent')}

El nom fa referència a les dents que tenen a les mandíbules. Reben nombroses denominacions vulgars, com parotets, libèl·lules, espiadimonis, avions, helicòpters, estiracabells, talladits, tallanassos, pixavins o damisel-les. Els adults es caracteritzen per tenir dos parells d'ales iguals o molt semblants de mida, membranoses i amb una abundant venació transversal. Aquestes ales poden quedar-se en repòs paral·leles (subordre Anisoptera) o perpendiculars al cos (subordre Zygoptera) (figura 5). Les nimfes i els adults són depredadors d'altres insectes, però en general no tenen interès agroforestal.
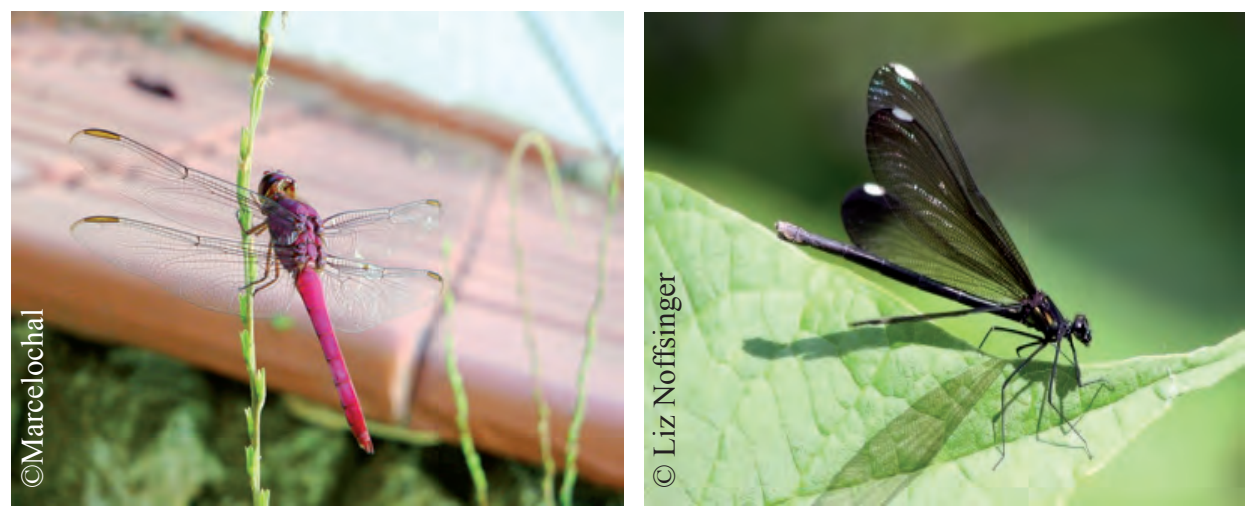

Figura 5. Imatges d'un odonat anisòpter (ales en repòs paral·leles) (esquerra) i d'un zigòpter (ales en repòs perpendiculars al cos) (dreta)

\subsubsection{Ordre Orthoptera (= ales que formen angle recte)}

Reben el nom comú de grills, llagostes, llagostins, cadells, saltamartins, pantiganes, someretes, saltirecs o saltirons (figura 6). Agrupa unes 20.000 espècies. Hi trobem espècies devastadores quan passen a la fase gregària, com fan algunes espècies de llagosta (Dociostaurus maroccanus (Thunberg) o Schistocerca gregaria Forsskål); d'altres perjudicials en cultius hortícoles, com Gryllotalpa gryllotalpa (L.), coneguda com a grilla llauradora, talla-arròs, talla-cebes o cuc hortolà (figura $6 \mathrm{C}$ ); i moltes espècies indiferents (grills, llagostes, saltarells, etc.). Tenen aparells bucals mastegadors. Les ales anteriors estan lleugerament endurides (tegmens o tegmines) i generalment tenen el tercer parell de potes modificat per botar (figura 6A i 6B), per cavar (en aquest cas el primer parell) (6C) o senzillament marxador (6D). 

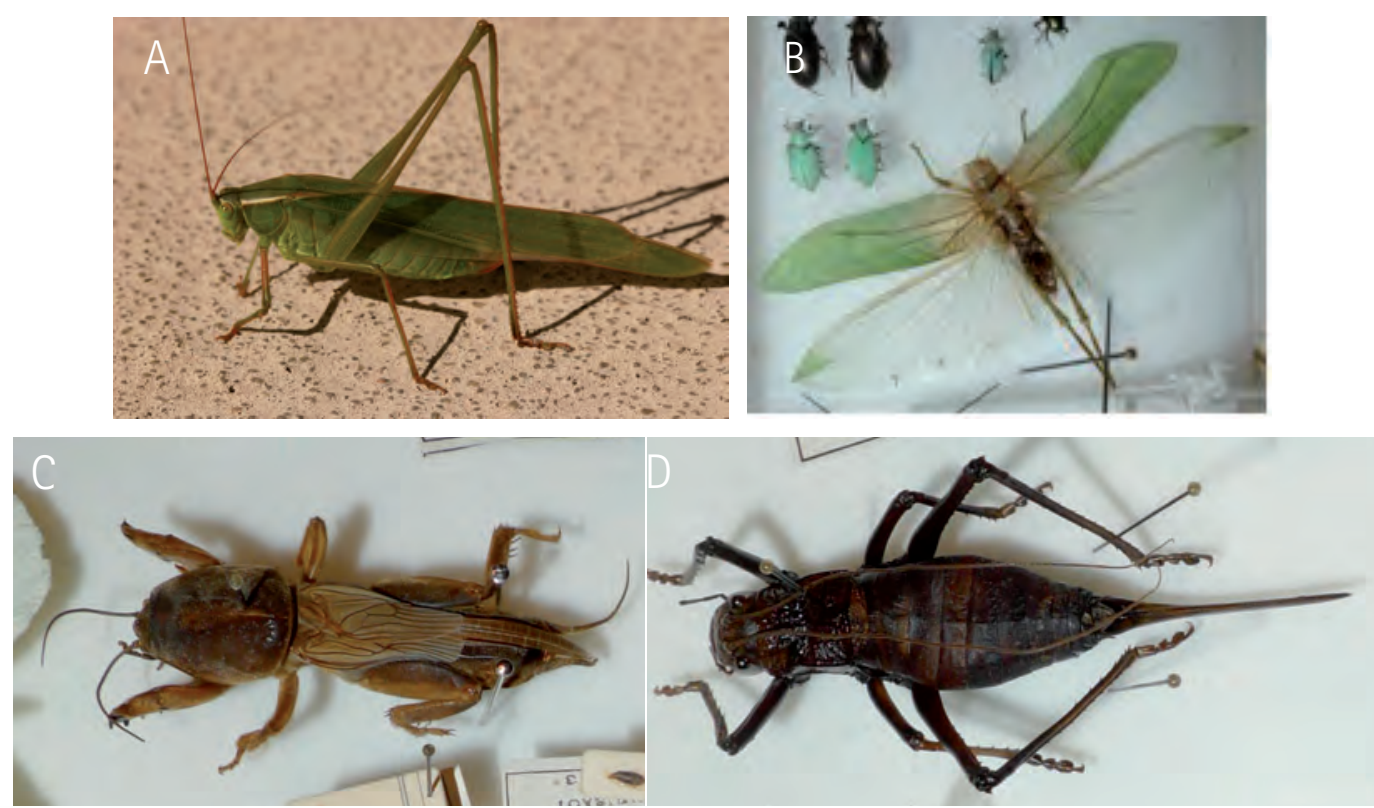

Figura 6. Aspecte d'un ortòpter saltador (A); detall de les ales anteriors i posteriors d'un ortòpter (B); d'una grilla llauradora Gryllotalpa gryllotalpa (C) i d'un grill (D)

\subsubsection{Ordre Grylloblattodea}

Es creu que d'aquest ordre evolucionaren els ortòpters (grills) i els dictiòpters (blàtids). Són espècies àpteres sense cap interès agroforestal, on destaca l'espècie Grylloblatta campodeiformis Walker (figura 7). Es tracta d'insectes depredadors, o necròfags, encara que també poden menjar algunes restes vegetals. Es troben a Nord-Amèrica, Sibèria i el Japó.

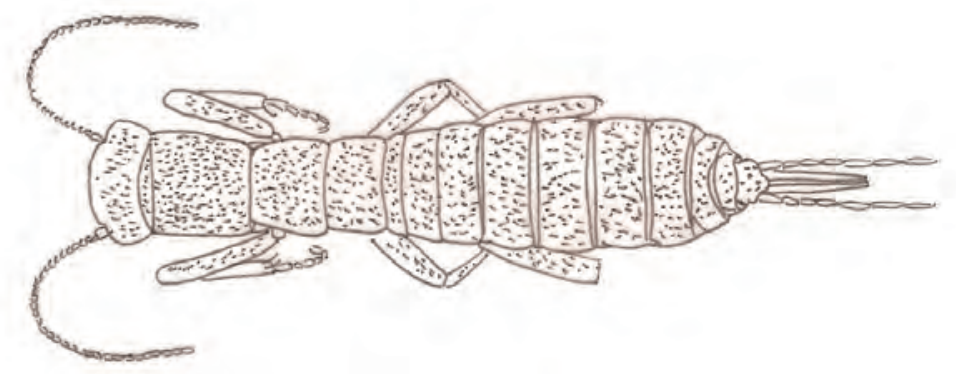

Figura 7. Dibuix del grilloblàtid Grylloblatta campodeiformis. Adaptat de Richards i Davis (1984)

\subsubsection{Ordre Dermaptera (= ales de cuiro)}

Engloba unes 1.800 espècies, que es coneixen amb els noms vulgar de tisoretes, cuca-talles, sastres, papasastres o papaorelles. Pel fet de ser omnívores, segons el cultiu on es troben, poden considerar-se perjudicials (bresquillera, nectarina, clavell, encisam, etc.), beneficioses (perera, pomera, etc.), o indiferents. En alguns casos són depredadores d'altres insectes. Tenen aparells bucals mastegadors. Les ales anteriors són molt curtes i estan un poc endurides (tegmines), mentre que les posteriors són membranoses, encara que també hi són comunes les formes àpteres (figura 8). 


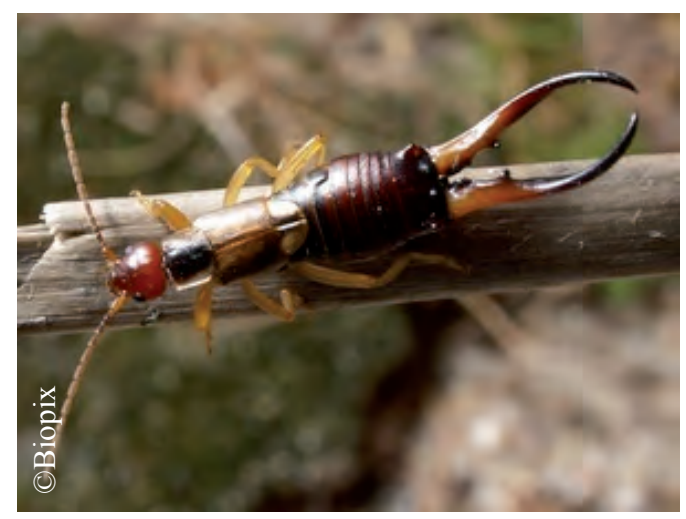

Figura 8. Tisoreta comuna europea, Forficula auricularia L.

\subsubsection{Ordre Plecoptera (= ales plegades o trenades)}

Aquestes espècies reben els noms comuns de perles, mosques d'aigua o mosques de les pedres. Tant els adults com les nimfes viuen associats a hàbitats aqüícoles poc contaminats i s'empren com a bioindicadors d'aigües netes i oxigenades. També acostumen a ser emprades com a esquer de pesca. Els adults tenen aparell bucal mastegador i ales membranoses amb venació abundosa, i són més menudes les davanteres (figura 9). No tenen interès agrícola.
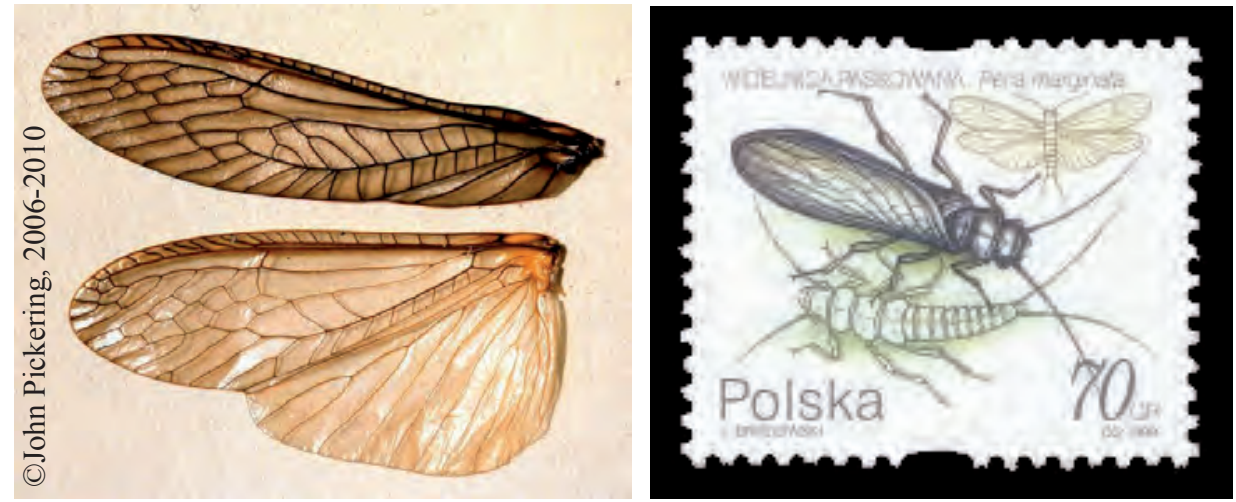

Figura 9. Aspecte de les ales dels plecòpters (esquerra) i representació en un segell de l'adult i la nimfa d'aquest ordre (dreta)

\subsubsection{Ordre Embioptera (= ales persistents)}

Les espècies d'aquest ordre es troben en zones tropicals i subtropicals. No tenen interès agrícola. Les femelles i les nimfes són fitòfagues, mentre que els mascles no s'alimenten. Reben el nom comú de teixidors perquè viuen a l'interior de túnels construïts amb seda a la terra, sota les pedres (figura 10). 

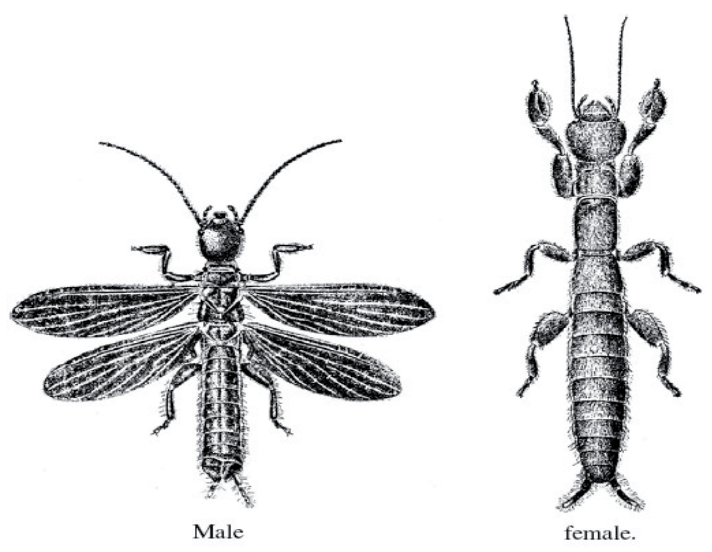

Figura 10. Mascle (esquerra) i femella (dreta) de l'embiòpter Embia major Imms

\subsubsection{Ordre Dictyoptera (= ales reticulades)}

Aquest ordre conté dos subordres: el subordre Blattodea i el subordre Mantodea. El subordre Blattodea inclou les cuques molles, cuques paneres, escarabats de cuina, paneretes i paneroles, i el Mantodea els pregadéus i els voltacampanes. Els adults tenen el cap hipògnat, l'aparell bucal mastegador i en general dos parells d'ales amb el primer parell lleugerament endurit que protegeix del segon, de major grandària. En els Blattodea el pronòtum és gran, i en forma de disc, i té el primer parell de potes marxador, mentre que en els Mantodea el pronòtum és allargat $i$ el primer parell de potes és raptor. No tenen importància agroforestal però alguns Blattodea es consideren plagues domèstiques com Periplaneta americana (L.), Blattella germanica (L.) o Blatta orientalis L. (figura 11 esquerra), mentre que els Mantodea són generalment depredadors (figura 11 dreta).
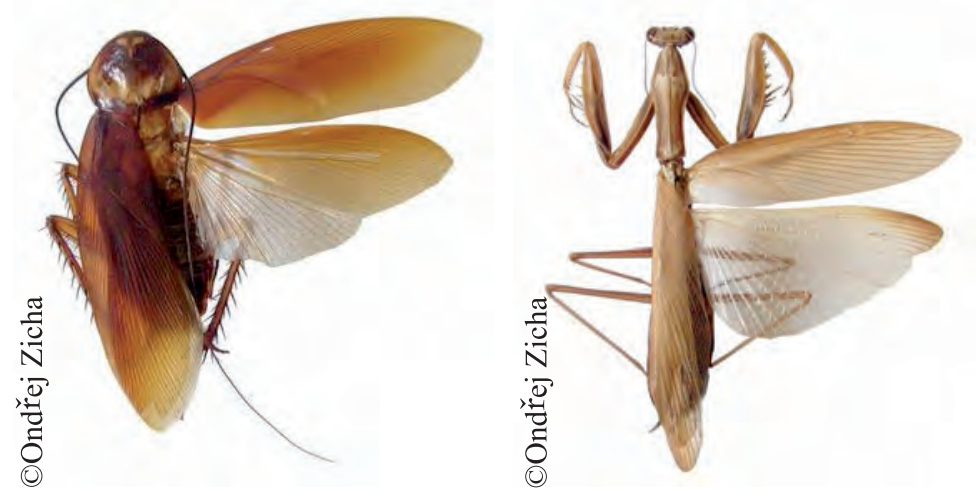

Figura 11. Representant del subordre Blattodea (Periplaneta americana) (esquerra) i del subordre Mantodea (dreta) 


\subsubsection{Ordre Isoptera (= ales iguals)}

Hi ha unes 2.300 espècies de tèrmits o formigues blanques, on destaquen Kalotermes flavicollis (F.) i Reticulitermes lucifugus (Rossi), que poden causar danys en vinyes, fruiters i fusta de construcció amb el seu aparell bucal mastegador dotat amb fortes mandíbules (figura 12). Tenen un parell d'ales membranoses d'igual mida que es perden durant el vol nupcial.

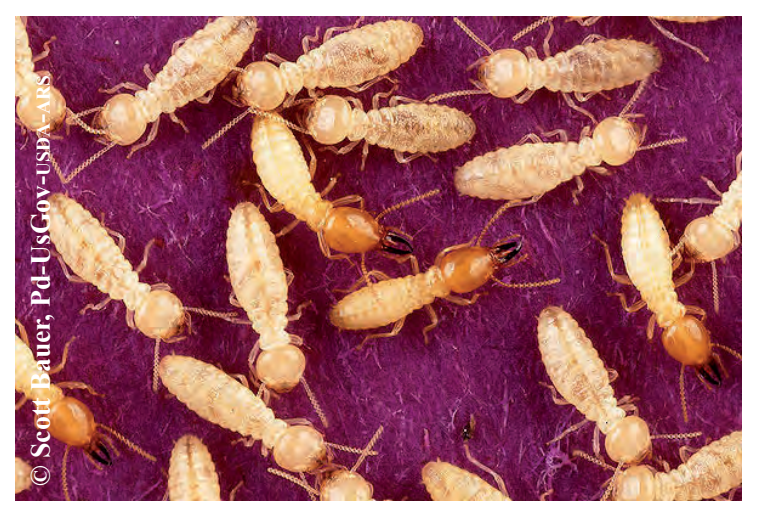

Figura 12. Aspecte de les obreres i dels soldats (els individus amb mandíbules grans) de l'ordre Isoptera

\subsubsection{Ordre Phasmida (= fantasma o espectre)}

Es coneixen vulgarment com a cavalls de faves o bastons. Són insectes sedentaris que escapen dels seus depredadors imitant fulles i branquetes (figura 13). Es caracteritzen pel fet de tenir el mesotòrax i el metatòrax molt allargat, l'aparell bucal mastegador i les potes llargues i primes. Es tracta d'espècies àpteres, braquípteres o alades (ales reduïdes en les femelles, i desenvolupades en els mascles) amb les ales anteriors lleugerament esclerotitzades. Són espècies fitòfagues sense interès agroforestal, llevat d'algunes espècies australianes i nord-americanes que poden ocasionar danys en la vegetació.
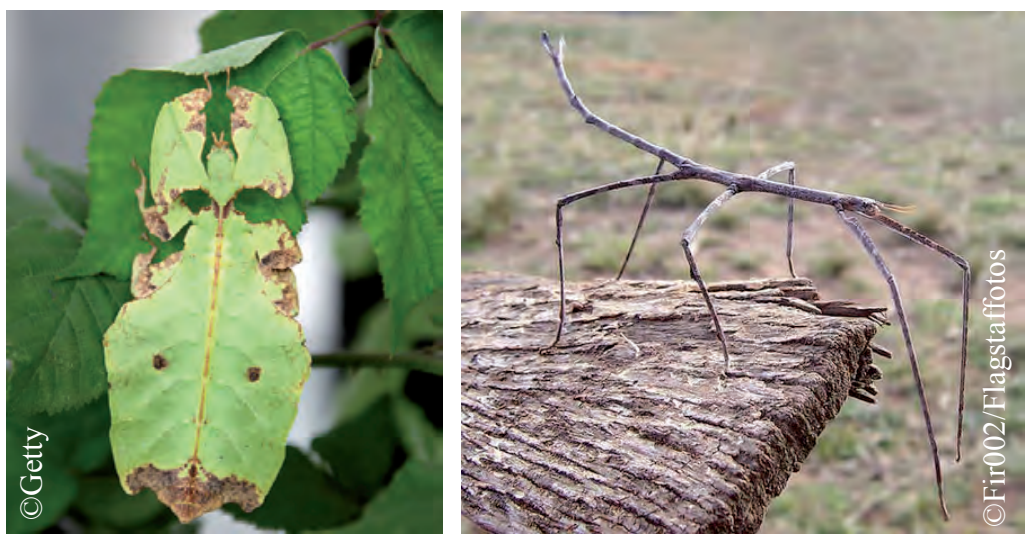

Figura 13. A l'esquerra, fàsmid que imita fulles i, a la dreta, un altre que imita tiges 


\subsubsection{Ordre Mantophasmatodea}

Es coneixen com a gladiadors. És l'ordre de més recent creació. El seu aspecte recorda els màntids i els fàsmids, i d'ací en prové el nom, si bé aquests són àpters (figura 14). Són insectes depredadors, però sense interès agroforestal.

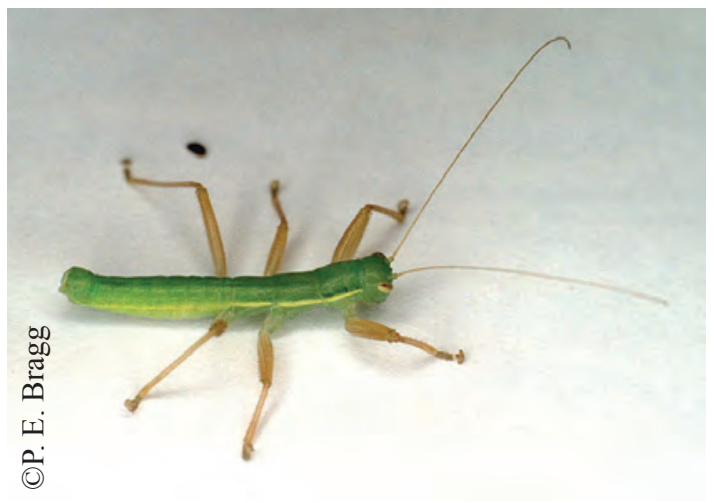

Figura 14. Aspecte d'un mantofasmatodeu

\subsubsection{Ordre Zoraptera (= purament àpters o estrictament àpters)}

Les espècies d'aquest ordre reben el nom de 'pur àpters' ja que quan es descobriren es pensava que només n'existien formes àpteres (figura 15). Es troben a tot el món llevat de la regió Paleàrtica. Són insectes de mida molt reduïda $(<4 \mathrm{~mm})$. S'alimenten d'espores de fongs, d'àcars o d'altres artròpodes menuts. No tenen importància agroforestal.
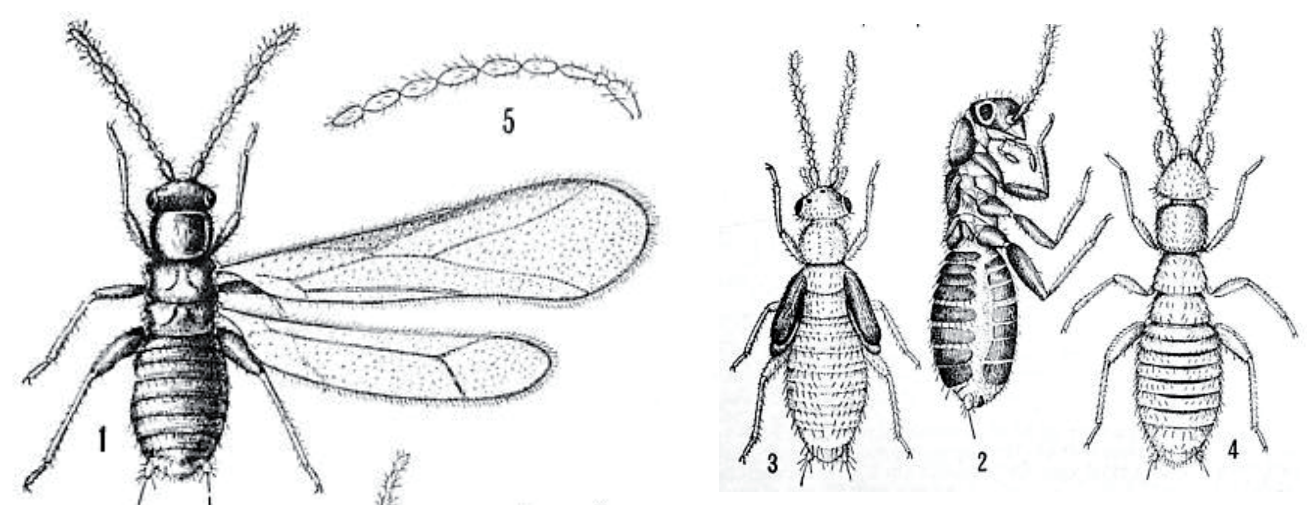

Figura 15. Zorotypus hubbardi Caudell. (1) Femella alada; (2) femella sense ales; (3) nimfa d'una forma alada; (4) femella adulta d'una forma àptera;

(5) antena d'una forma àptera 


\subsubsection{Ordre Psocoptera (= rosegadors amb ales)}

Es coneixen vulgarment com a polls dels llibres. Són insectes molt menuts amb caps grossos i colors groguencs i marrons. Hi ha espècies alades amb nerviació senzilla $i$ ales plegades en teuladet $i$ àpteres (figura 16). S'alimenten de restes vegetals, d'animals, i fins i tot de productes emmagatzemats. Són molt comunes a les fulles dels cítrics, on probablement s'alimenten d'alguns fongs, com la fumagina.
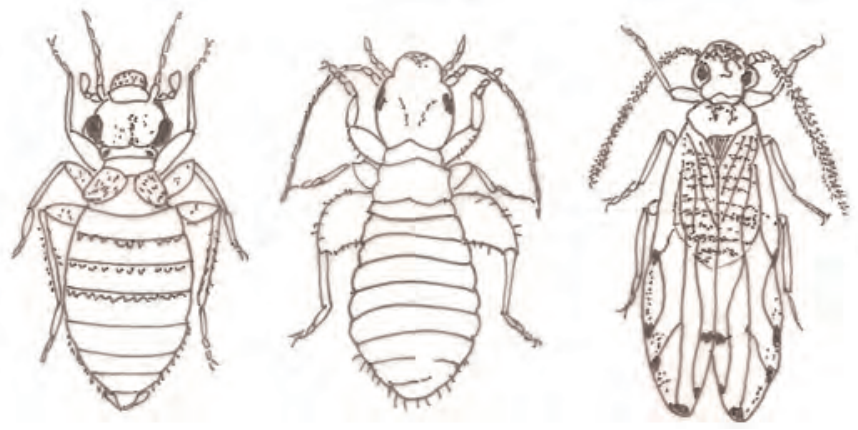

Figura 16. Exemples de psocòpters amb les ales reduïdes, àpters i alats.

Adaptat de Gillott (2005)

\subsubsection{Ordre Phthiraptera (= polls sense ales)}

Es coneixen vulgarment com a polls, polls del pubis o polls de l'aviram. Es tracta d'espècies sense interès agroforestal però de gran interès mèdic i veterinari, que es reprodueixen com a ectoparàsits obligats de les aus (els antics Mallophaga) i dels mamífers (subordre Anoplura) i poden transmetre malalties a l'home com l'espècie Pediculus humanus L., que pot ser vector del tifus endèmic i de les febres quintanes. Són insectes àpters de mida molt reduïda $(0,3-10 \mathrm{~mm})$ que es caracteritzen pel fet que presenten potes prensores per agafar-se als pèls o plomes de l'hoste (figura 17).
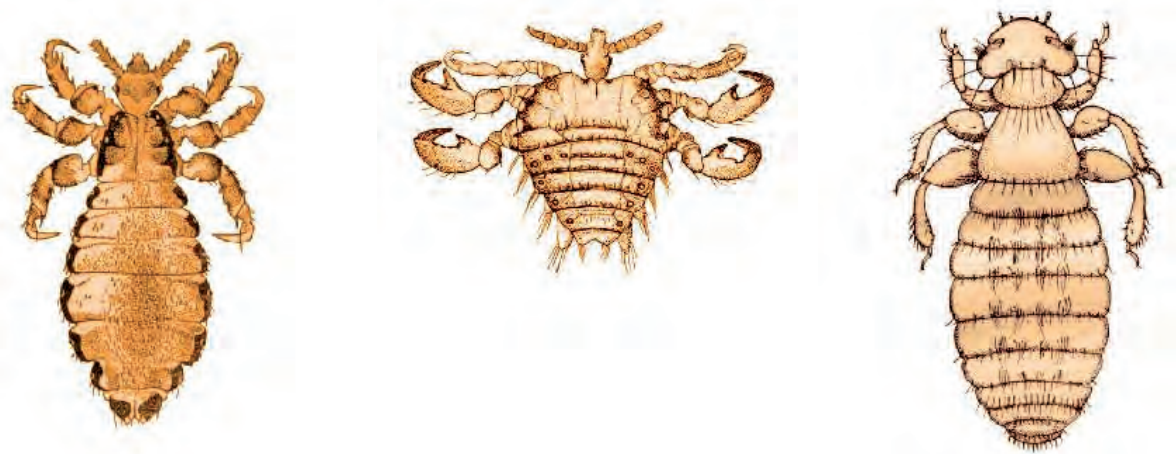

Figura 17. Dibuixos d'esquerra a dreta de Pediculus humanus, Pthirus pubis (L.) i Menopon gallinae (L.) 
Aquest ordre engloba dos subordres: el subordre Heteroptera (ales de consistència no homogènia (hemèlitres) que es creuen damunt del cos quan reposen) $i$ el subordre Homoptera (ales de consistència homogènia que reposen sense creuar-se). Dintre del subordre Heteroptera es coneixen unes 38.000 espècies, conegudes com a xinxes, bernats o escarabats xinesos. Són insectes de grandària variable, però que sempre presenten el primer parell d'ales transformat en hemèlitres i l'aparell bucal picador-xuclador típic. Hi trobem espècies perjudicials, com les xinxes del cereal, les de la col, els tigres de l'ametler i les pudentes, així com de beneficioses: els depredadors Orius spp., Anthocoris spp., etc. (figura 18).

El subordre Homoptera té una gran importància agrícola, ja que hi trobem moltes espècies que directament o indirectament (transmissió de malalties, fumagina, etc.) són perjudicials per als nostres cultius. Tenen un aparell bucal picador-xuclador molt semblant al dels heteròpters, i solen tenir una grandària reduïda. Hi trobem les mosques blanques, els polls, els cotonets, els pugons, les psil-les, les cigales, etc. També hi trobem alguna espècie beneficiosa com la cotxinilla del carmí o la de la laca. La morfologia d'aquests és molt variable: hi ha espècies que no semblen insectes (p. ex. cotxinilles) $\mathrm{i}$ d'altres amb ales perfectament desenvolupades (p. ex. cigales) (figura 18).
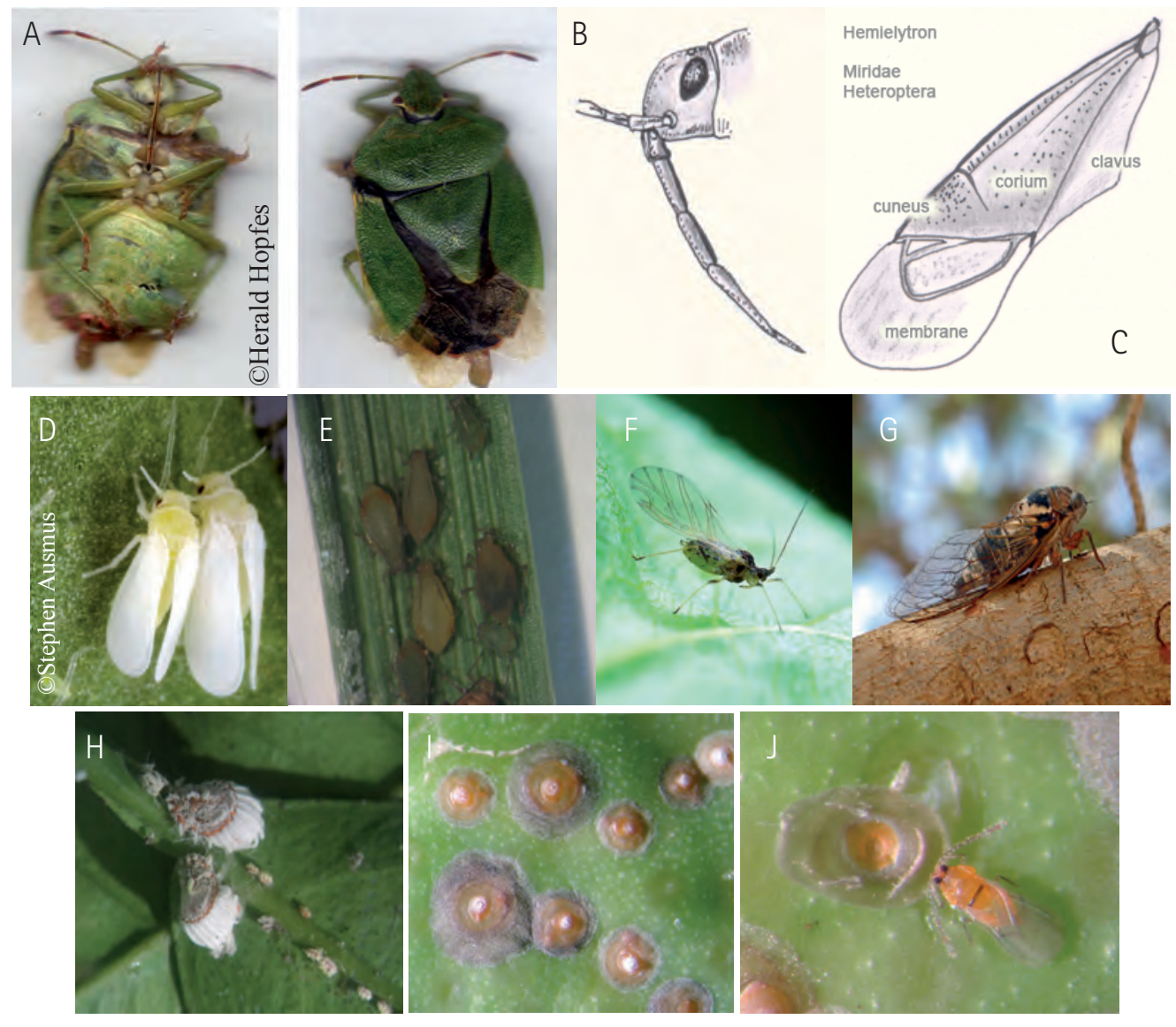

Figura 18. Vista ventral i dorsal d'un hemípter heteròpter on es pot apreciar el rostre picador-xuclador i els hemèlitres (A); dibuix d'un rostre picador-xuclador (B); dibuix d'un hemèlitre (C); mosca blanca (hemípter homòpter) (D); pugó àpter (E) i alat (F) (hemípter homòpter); cigala (hemípter homòpter) $(\mathrm{G})$; cotxinilla acanalada (hemípter homòpter) $(\mathrm{H})$; femelles de poll roig de Califòrnia (hemípter homòpter) (I); mascle de poll roig de Califòrnia (hemípter homòpter) (J) 


\subsubsection{Ordre Thysanoptera (= ales amb serrells)}

S'han descrit unes 5.100 espècies de tisanòpters, coneguts vulgarment com a trips o xinxes del mal temps. Són molt menuts i, a més de la presència de serrells a les ales, els caracteritza l'aparell bucal picador-xuclador asimètric (figura 19). Hi ha espècies fitòfagues (Thrips tabaci Lindeman, Frankliniella occidentalis (Pergande), Liothrips oleae (Costa), etc.), micòfagues i depredadores (Aelothrips spp., Franklinothrips spp., etc.). Els danys que provoquen oscil·len des d'una minoració del creixement de les plantes, problemes d'esterilitat de flors i quallat, decoloració i deformació del lloc d'alimentació, a transmissió de virosis d'importància econòmica com el virus del bronzejat de la tomaca (TSwV, de l'anglès Tomato Spotted Wilt Virus) o, fins i tot, la mort de plantes joves.
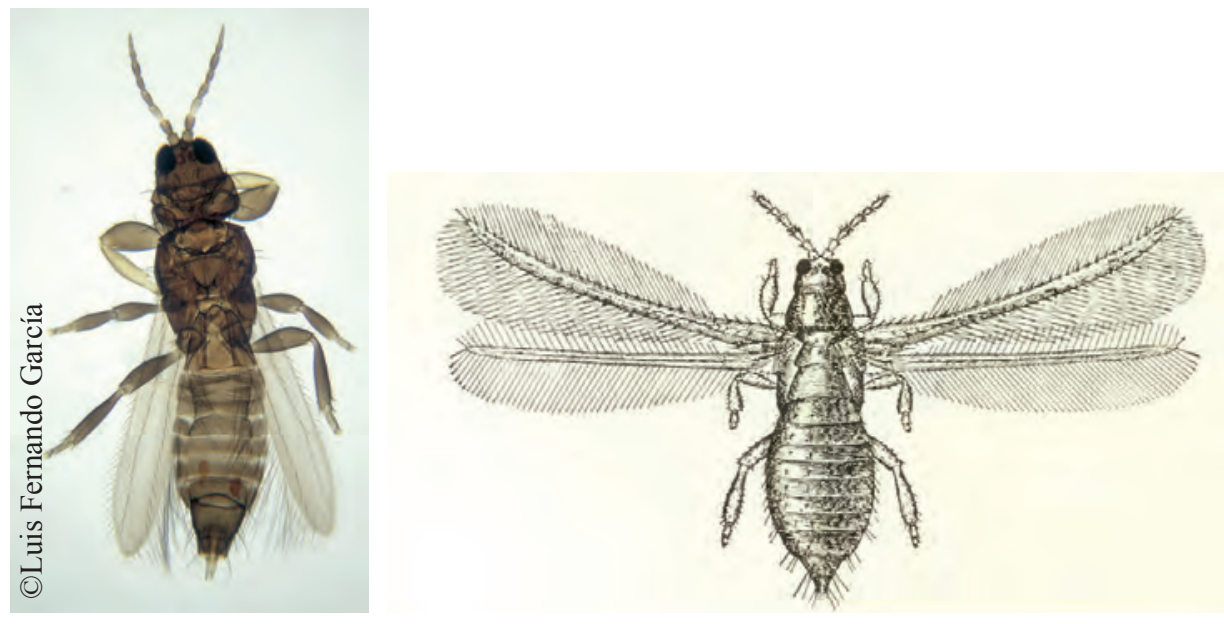

Figura 19. Fotografia (esquerra) i dibuix (dreta) d'un tisanòpter on es poden observar, entre altres trets, les ales amb serrells

\subsubsection{Ordre Mecoptera (= ales allargades)}

Es coneixen com a mosques escorpí pel segment abdominal terminal corbat cap amunt que té el mascle (figura 20). L'aparell bucal és de tipus mastegador i les ales es troben igualment desenvolupades amb àrees enfosquides. Les larves i els mascles són depredadors, a diferència de la femella, que sembla que s'alimenta de substàncies sucroses. No tenen interès agroforestal.

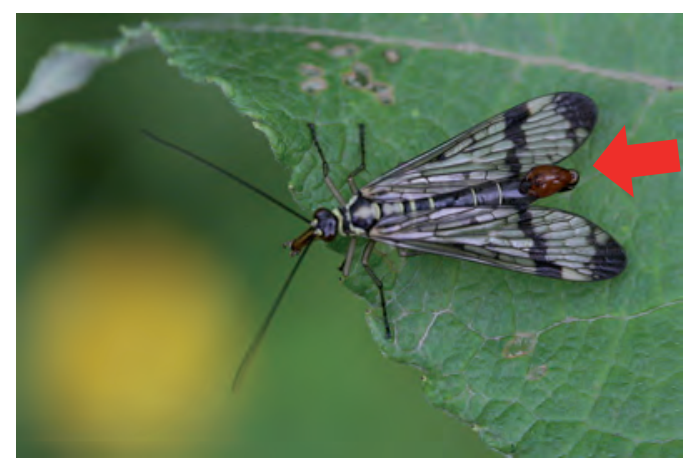

Figura 20. Fotografia d'un mecòpter mascle. Amb una fletxa roja s'assenyala el segment abdominal corbat que li dóna el nom comú de mosques escorpí a l'ordre 


\subsubsection{Ordre Lepidoptera (= ales cobertes d'escates)}

Hi ha més de 100.000 espècies de palometes descrites. N'hi ha de totes les grandàries, des de microlepidòpters de pocs mil·límetres, fins a macrolepidòpters de més de $10 \mathrm{~cm}$ d'envergadura alar. Presenten gairebé sempre larves de tipus eruciforme (erugues), pupa obtecta (o crisàlide) i els adults tenen un aparell bucal llepador especialitzat (espiritrompa), a més de presentar les ales cobertes d'escates, sovint de colors vius (figura 21). Les espècies minadores, però, tenen larves àpodes. La majoria d'espècies són fitòfagues, però també se n'han descrit de depredadores, de paràsites, i fins i tot amb alimentacions basades en queratines i ceres (arnes de la roba). En alguns casos resulten beneficioses per a l'home pels productes que fabriquen (seda) o perquè són hostes alternatius de molts enemics naturals que poden emprar-se en la seua cria massiva.
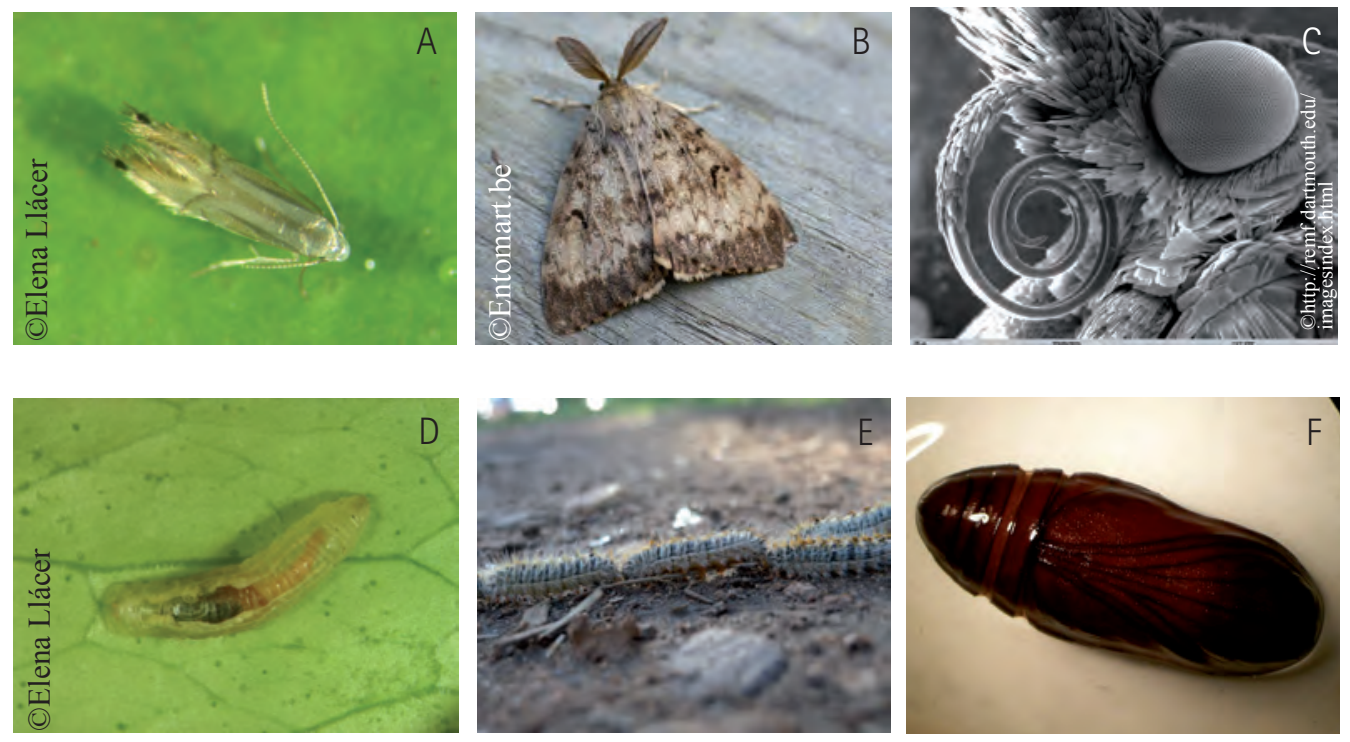

Figura 21. Femella de la minadora dels cítrics, Phyllocnistis citrella Stainton (A); mascle de l'eruga peluda de l'alzina Lymantria dispar L. (B); fotografia de l'aparell

bucal llepador (espiritrompa) dels lepidòpters $(\mathrm{C})$; larva àpoda de la minadora dels cítrics (D); eruga de tipus eruciforme de la processionària del pi (Thaumetopoea pityocampa Denis i Schiffermüller) (E); pupa obtecta o crisàlide (F)

\subsubsection{Ordre Trichoptera (= ales amb pèls)}

Es coneixen com a frigànies. El seu aspecte recorda el de les papallones nocturnes. Tenen les peces bucals molt reduïdes, a diferència de la hipofaringe, que es desenvolupa per xuclar líquids. Les larves construeixen refugis característics semblants a estoigs amb el material que les envolta (figura 22). Tant els adults com les larves viuen en llocs pròxims a aigües dolces. No tenen interès agroforestal. 

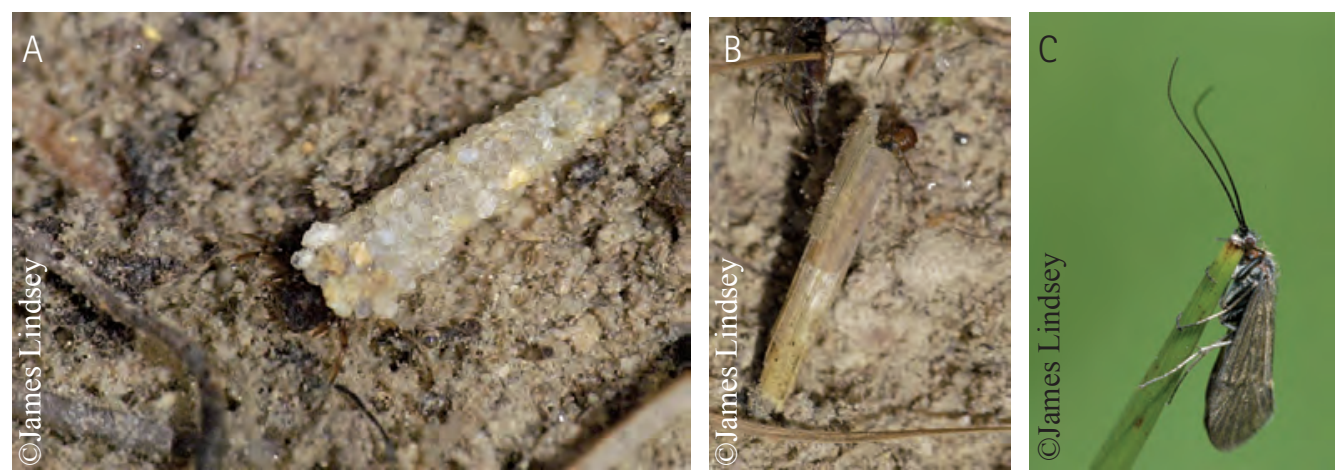

Figura 22. Estoigs de tricòpters amb la larva a l'interior (A i B);

adult de tricòpter $(\mathrm{C})$

\subsubsection{Ordre Diptera (= un parell d'ales)}

Les mosques constitueixen un dels grups dels insectes millor adaptats al medi. N'hi ha unes 85.000 espècies. Tenen el segon parell d'ales vestigial (balancins) i l'aparell bucal sempre transformat (perforador, llepador, xuclador, etc.). Les seues larves són sempre àpodes i la pupa és de tipus coartat, semblant a un barrilet, o obtecta. Hi ha nombroses espècies fitòfagues (mosques de la fruita, minadores, típules, etc.), així com n'hi ha de depredadores (sírfids, cecidòmids, etc.) i, fins i tot, de parasitoides (taquínids) (figura 23).
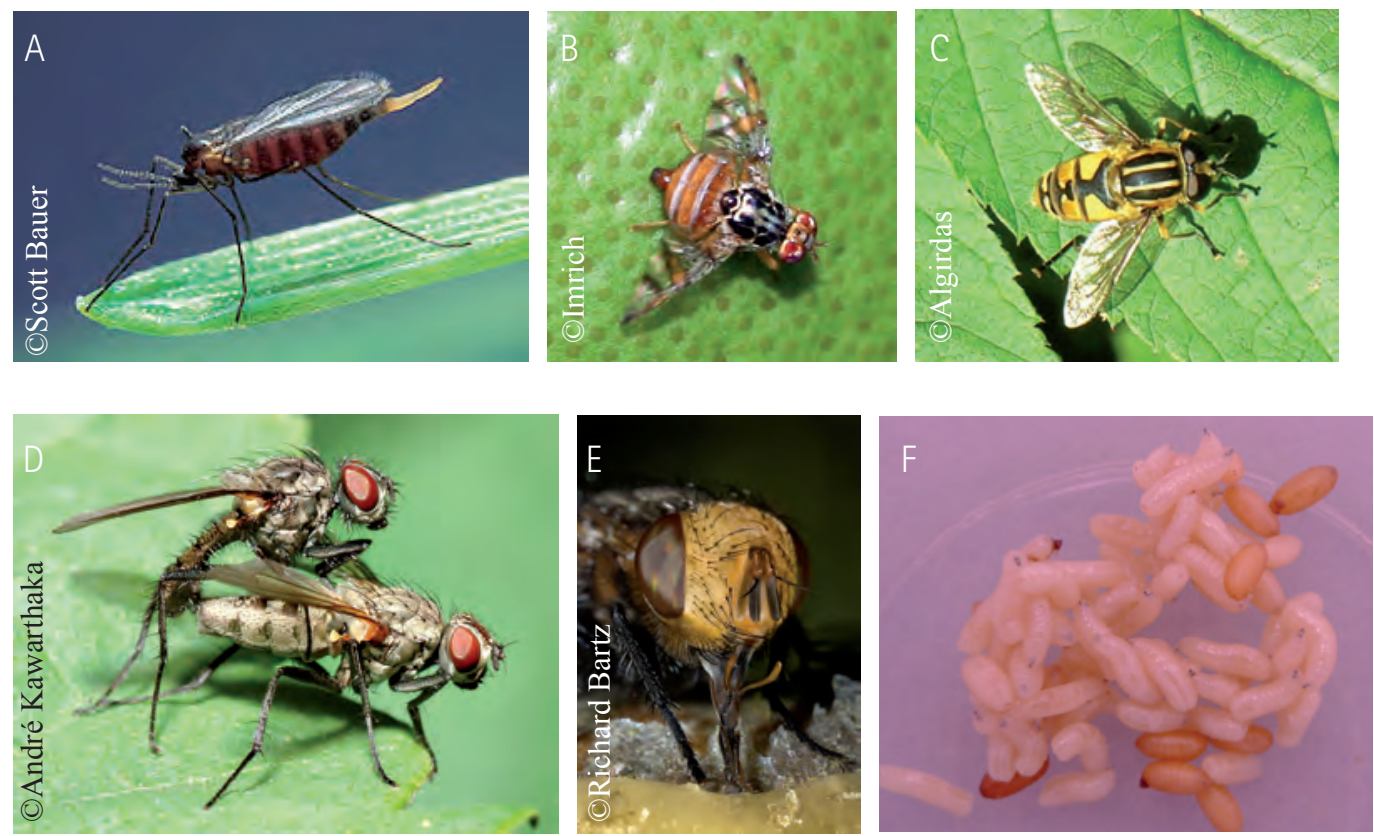

Figura 23. Mosquit del blat, Mayetiola detructor (Say) (A); mosca de la fruita, Ceratitis capitata (Wiedemann) (B); sírfid, Helophilus affinus Wahlberg (C); mosca de la ceba, Delia antiqua (Meigen), on es pot observar molt bé el segon parell d'ales modificat en balancins (D); detall de l'aparell bucal xuclador d'alguns dípters (E); larves àpodes i pupes coartades de la mosca de la fruita $(\mathrm{F})$ 


\subsubsection{Ordre Siphonaptera (= boca en forma de tub $i$ sense ales)}

Són les puces. Es tracta d'insectes àpters de mida reduïda, aparell bucal picadorxuclador adaptat per perforar la pell i xuclar la sang, i cos comprimit lateralment. No tenen interès agroforestal però sí mèdic $i$ veterinari perquè poden actuar com a vectors i transmetre malalties a l'home $\mathrm{i}$ als animals com la pesta bubònica $\mathrm{o}$ el tifus (figura 24).
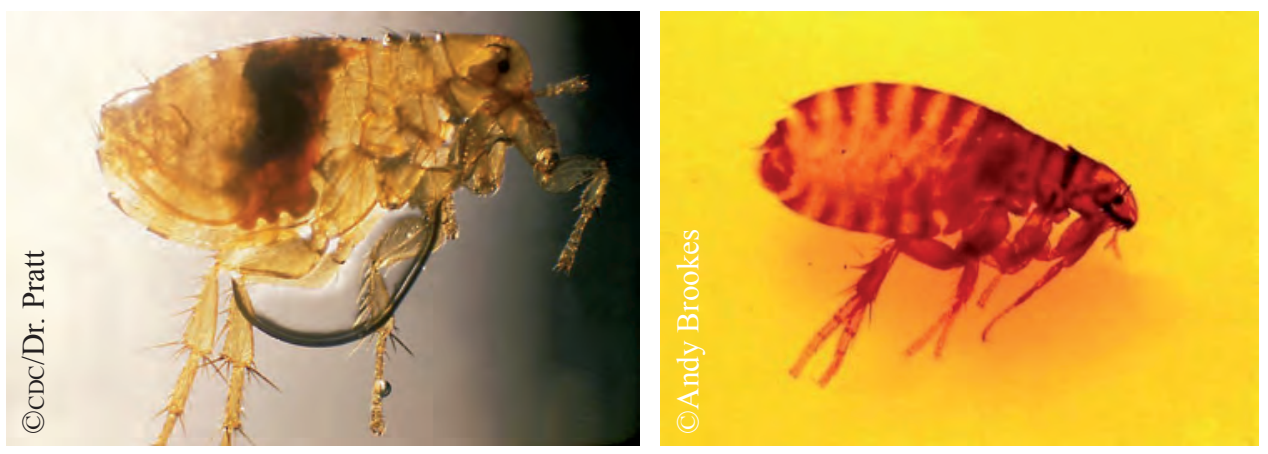

Figura 24. Exemples de puces. Puça de la rata oriental, Xenopsylla cheopis (Rothschild), principal vector de la pesta bubònica (esquerra); i puça del gat, Ctenocephalides felis

(Bouche) (dreta)

\subsubsection{Ordre Neuroptera (= ales amb nervis)}

Es tracta d'un grup molt heterogeni, que comprèn unes 5.000 espècies, d'interès agronòmic com a depredadors, generalment tant en estadi adult com larvari (larves campodeïformes). Inclou les crisopes, formigues lleó i les mantispes, i espècies més menudes, com els hemeròbids i les conwèntzies. Les ales són membranoses i de la mateixa mida, $i$ en repòs es col·loquen com si formaren una teulada de dues aigües (figura 25).
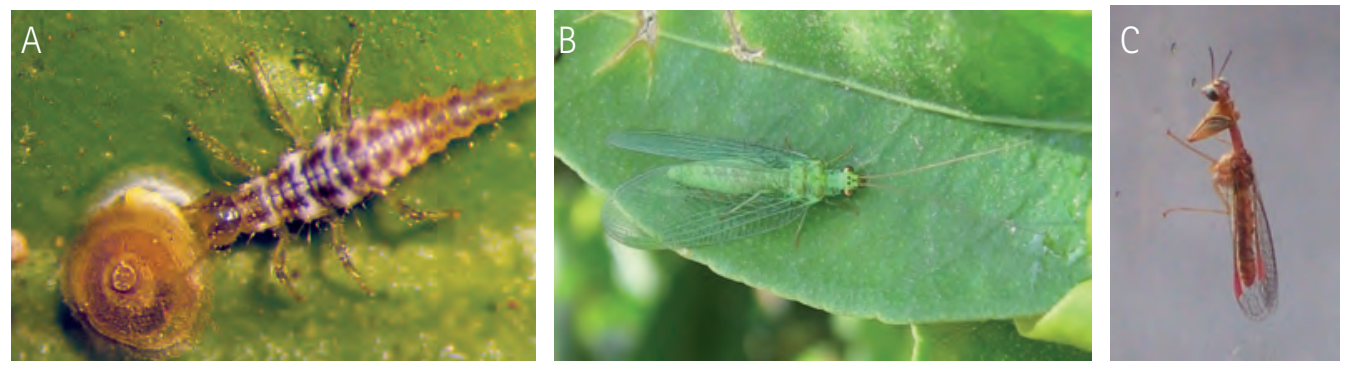

Figura 25. Larva (A) i adult (B) de crisopa; adult de mantispa (C)

\subsubsection{Ordre Megaloptera (= ales gegants)}

Són insectes de gran mida dotats d'aparell bucal mastegador, de gran ulls i amb dos parells d'ales que mesuren el mateix, amb venació primitiva i amb nombroses venes transversals (figura 26). Les larves són aquàtiques i depredadores. No tenen importància agroforestal. 


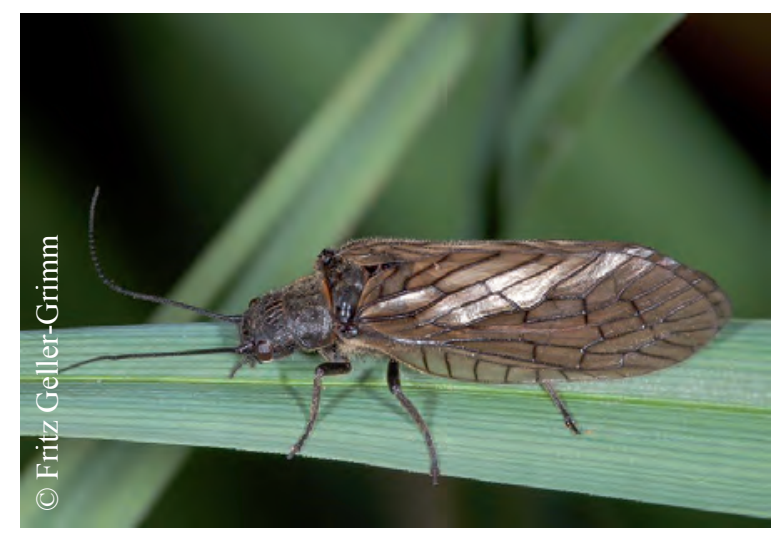

Figura 26. Adult de megalòpter

\subsubsection{Ordre Raphidioptera (= ales amb costures)}

Aquests insectes s'assemblen als megalòpters, amb la diferència que la part de darrere del cap i el protòrax s'allarguen i recorden un coll, per la qual cosa reben el nom d'insectes serp o insectes girafa (figura 27). Tant els adults com les larves són depredadors però no tenen interès agroforestal.
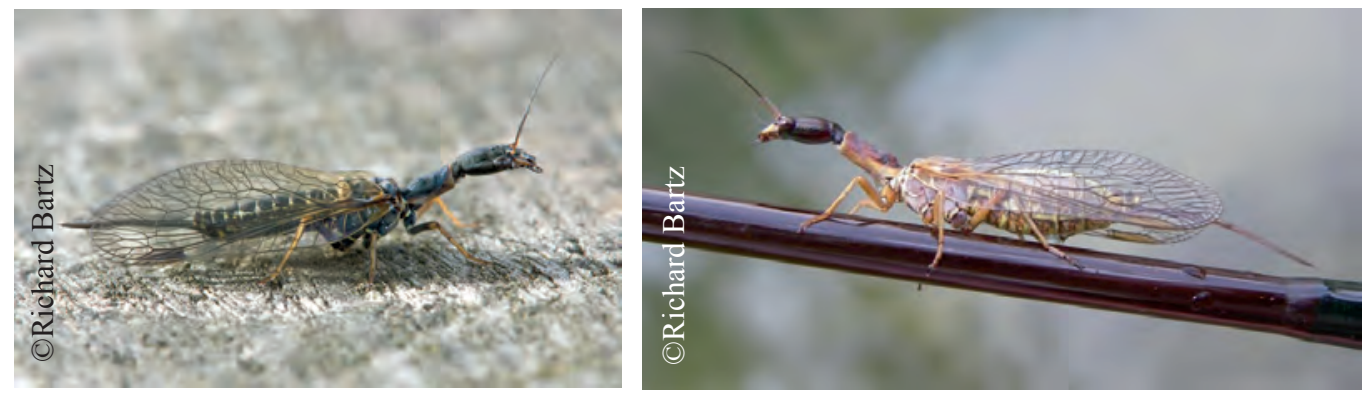

Figura 27. Adults de rafidiòpters

\subsubsection{Ordre Coleoptera (= ales endurides que formen un estoig)}

És l'ordre més nombrós dels insectes. Comprèn més de 300.000 espècies, que es troben arreu del món si exceptuem les profunditats marines. Tenen una grandària molt variable, i també ho és el tipus de larva que presenten (àpoda si viuen confinats, campodeïforme si són marxadores, escarabeïformes en els escarabeids). Les pupes solen ser lliures, però sovint protegides per un capoll terrós o fibrós. Hi trobem moltes espècies perjudicials (cucs blancs, cucs de fil d'aram, cabuts, corcs, morruts, etc.), però també moltes de depredadores (marietes, caràbids i estafilínids, fonamentalment) (figura 28). Aquest grup el tractarem amb més detall en la segona pràctica. 

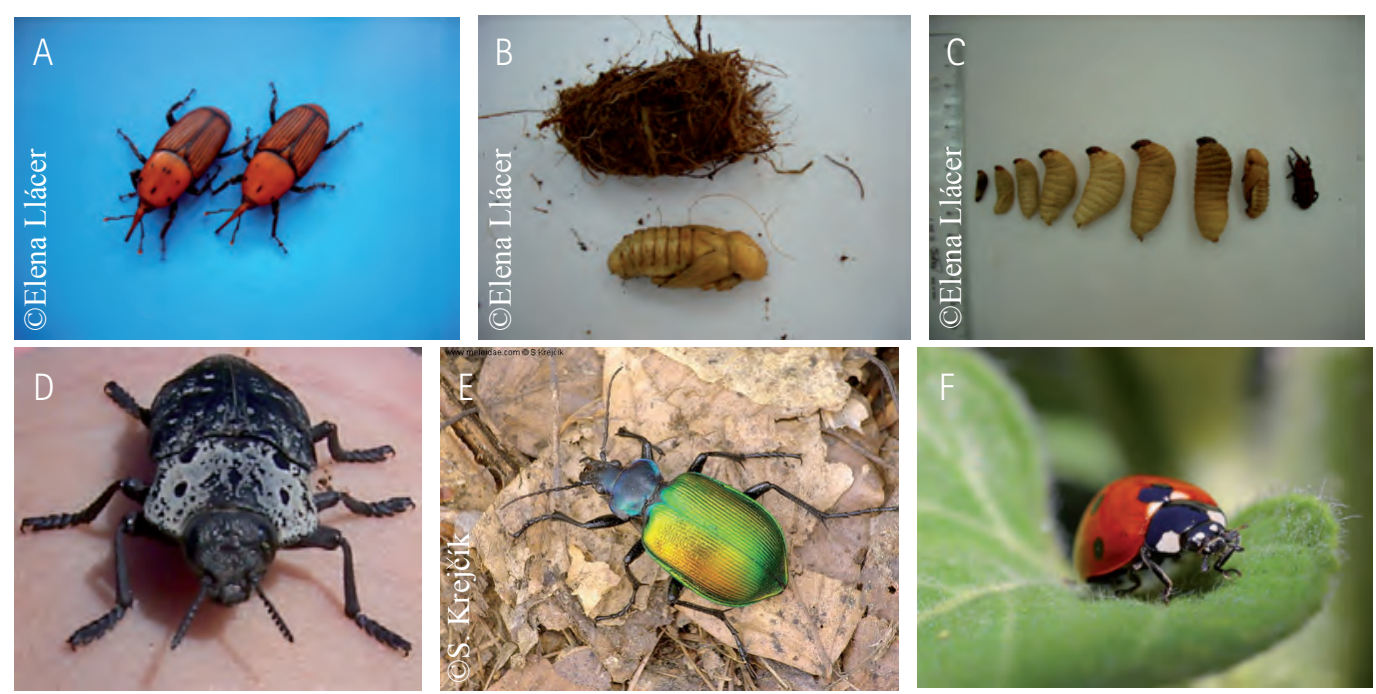

Figura 28. Diferents estadis del morrut roig de les palmeres, Rhyncophorus ferrugineus (Olivier) (A, B i C); adult del buprèstid Capnodis tenebrionis (L.) (D); caràbid depredador Calosoma sycophanta $(\mathrm{L}).(\mathrm{E})$; coccinèlllid depredador

Coccinella septempunctata L. (F)

\subsubsection{Ordre Strepsiptera (= ales retortes o corbades)}

Es tracta d'un ordre amb una biologia complexa: els mascles i els primers estadis larvaris són de vida lliure, a diferència de les femelles i els estadis larvaris més avançats, que són paràsits-parasitoids. La morfologia de la femella, com a conseqüència de la seua biologia, recorda la d'un cuc. El mascle presenta la peculiaritat morfològica de tenir el primer parell d'ales reduït a unes estructures que recorden els balancins dels dípters, mentre que el segon parell d'ales és membranós i està altament desenvolupat (figura 29). No tenen interès agroforestal, encara que recentment algunes espècies s'estan emprant en programes de control biològic contra hemípters, dípters, ortòpters i himenòpters plaga.

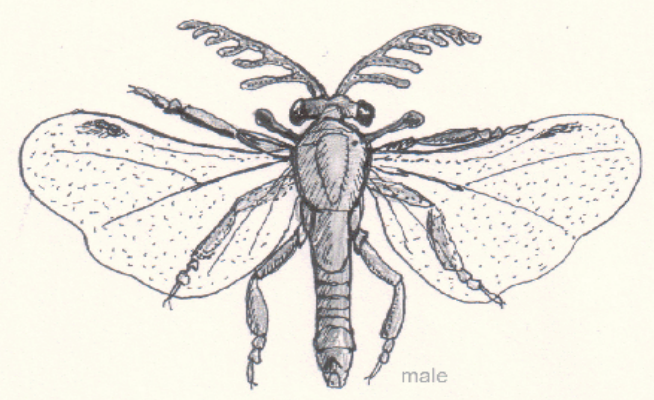

Figura 29. Dibuix d'un estrepsípter mascle 
Les més de 130.000 espècies que componen aquest grup es troben entre les més evolucionades dels insectes, i no és estrany trobar-hi espècies amb una organització social considerable (formigues, abelles, etc.) (figura 30). Trobem himenòpters de totes les mides (des de microscòpics fins a mesures d'uns quants centímetres). Els adults poden presentar la típica cintura de vespa (subordre Apocrita) o no (subordre Symphyta). Els símfits són fitòfags, amb larves eruciformes amb més de 5 parells de potes abdominals. En canvi, la majoria dels apòcrits són beneficiosos (pol-linitzadors, depredadors o parasitoides). Les larves són diverses, però la pupa és sempre lliure, encara que sovint coberta per un capoll de natura diversa (sedós, terrós, etc.).
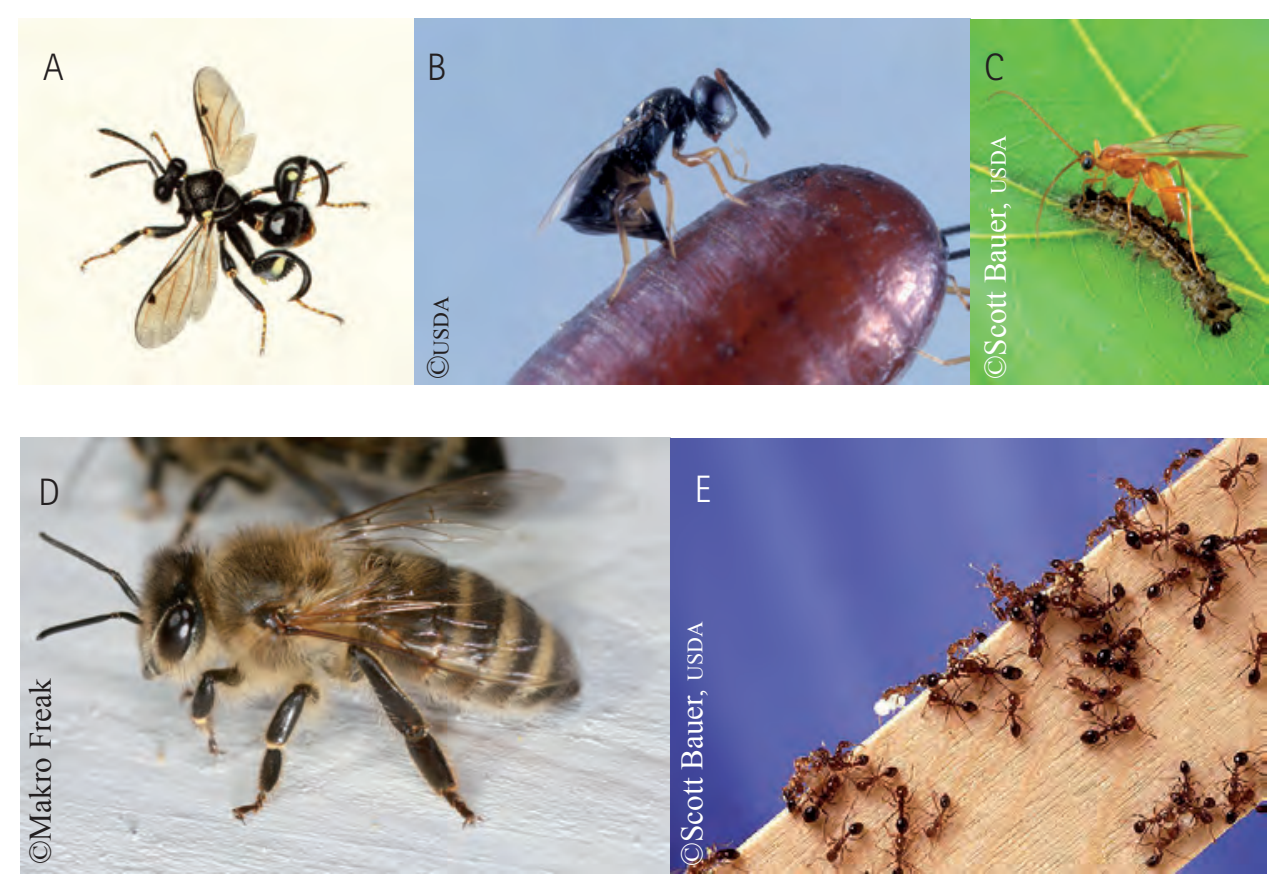

Figura 30. Dibuix de l'himenòpter calcídid Chalcis biguttata Spinola (A); himenòpter pteromàlid Muscidifurax raptor Girault i Sanders parasitant un pupari de mosca (B); Aleiodes indiscretus (Reardon) parasitant una eruga de lepidòpter $(\mathrm{C})$; abella mel·lera Apis mellifera L. (D); formiga roja Solenopsis invicta Buren (E) 


\subsection{Breus nocions morfològiques}

Abans d'entrar a identificar els insectes amb la clau que es proporciona cal conèixer les estructures principals que s'hi mencionen (figures 31-40).

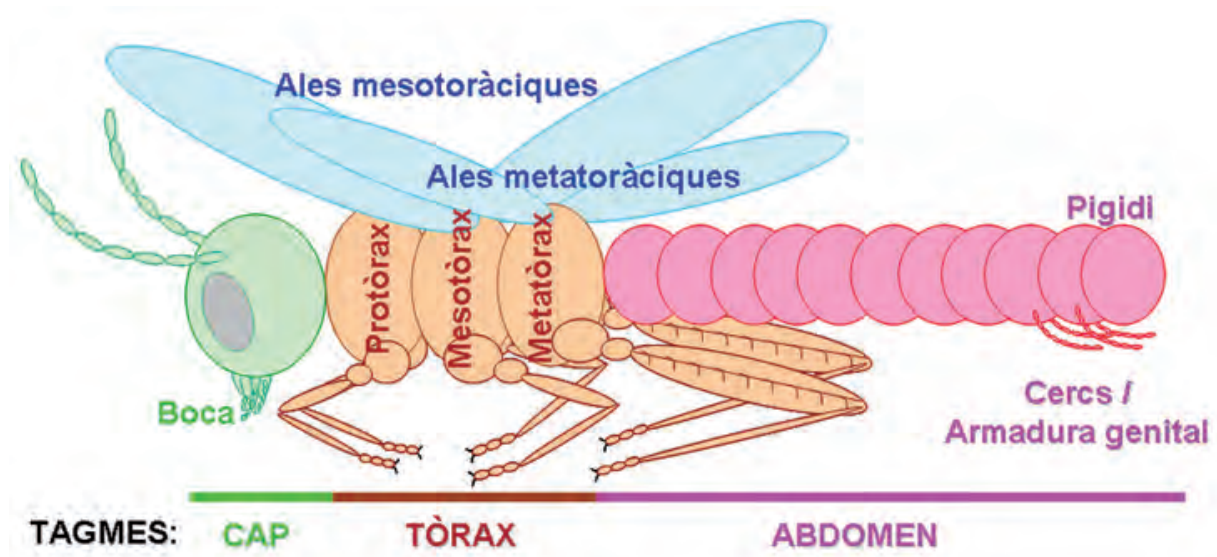

Figura 31. Esquema del cos d'un insecte

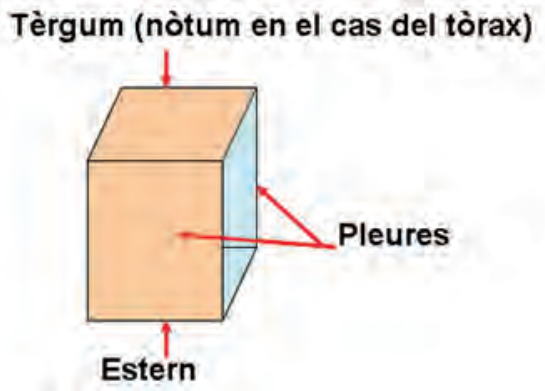

Figura 32. Esquema d'un segment del cos amb el nom que rep cadascuna de les regions

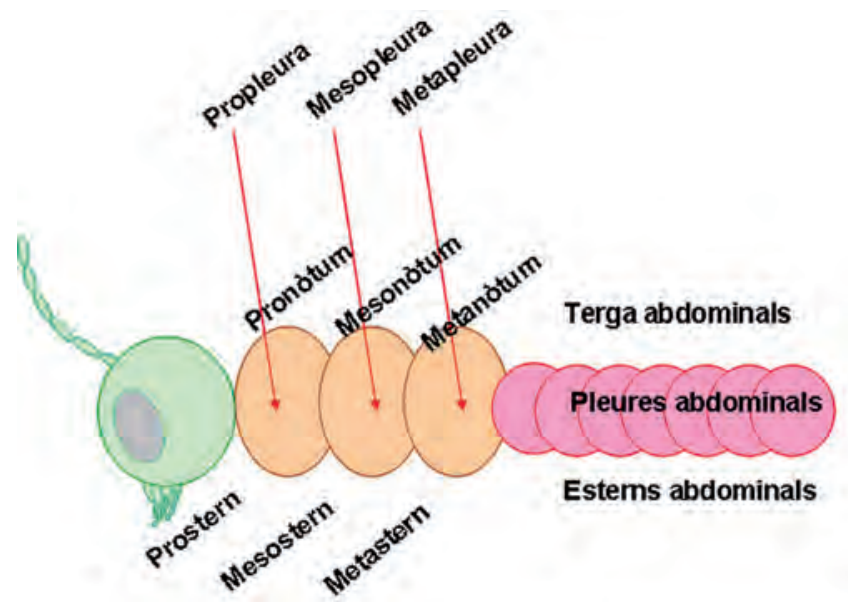

Figura 33. Noms que reben els diferents segments del cos 


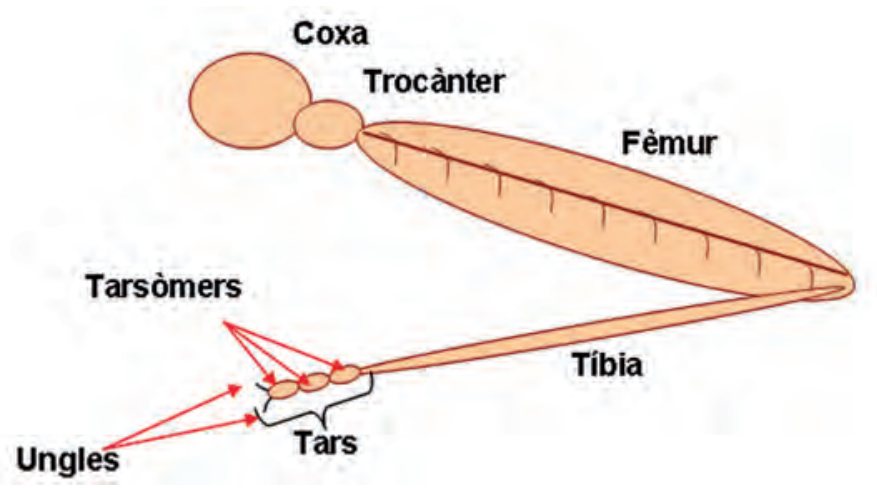

Figura 34. Esquema dels artells d'una pota

A

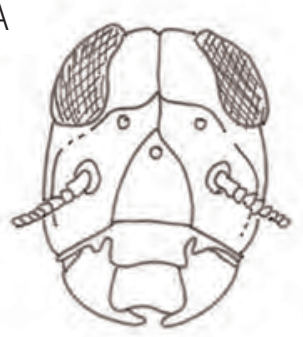

D

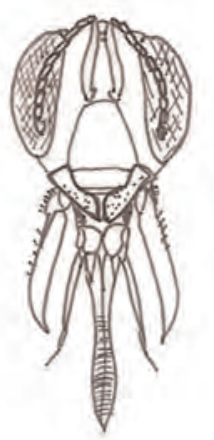

B

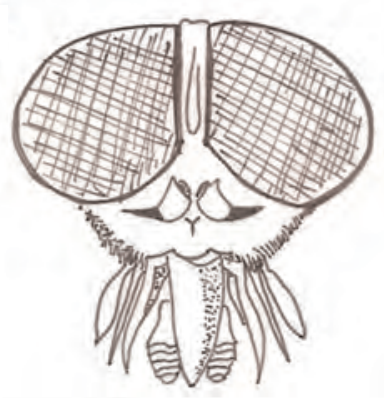

C

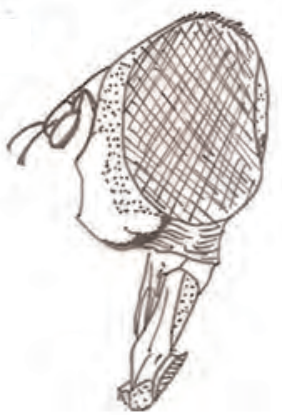

E

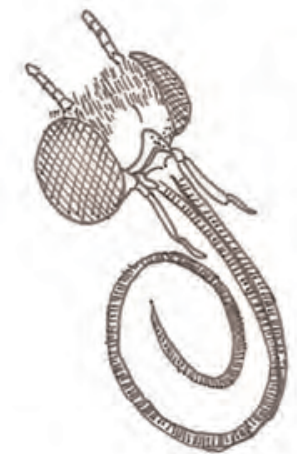

$\mathrm{F}$

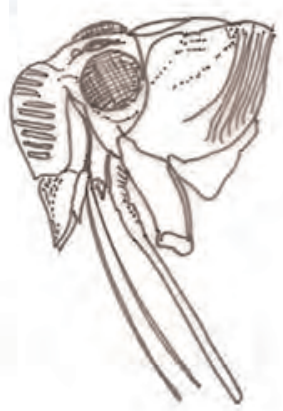

Figura 35. Exemples d'aparells bucals. A) Mastegador (ortòpter); B) perforador-xuclador (tàbec); C) xuclador (sírfid); D) mastegador-xuclador (abella); E) xuclador (espiritrompa de lepidòpter); F) picador-xuclador (homòpter). Adaptat de Nieto Nafria i Mier Durante (1985) i de De Liñan (1998)
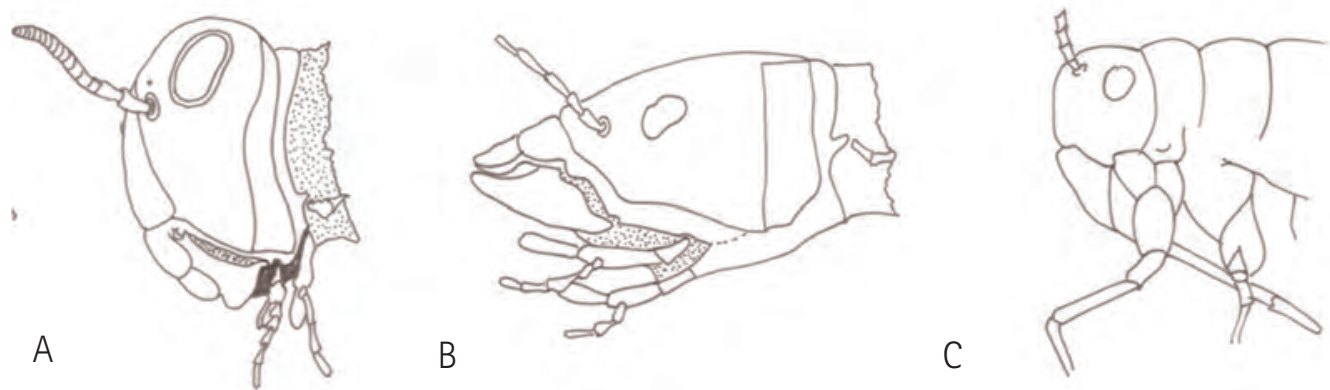

Figura 36. Exemples d'un cap hipògnat $\mathrm{o}$ ortògnat $(\mathrm{A})$, prògnat $(\mathrm{B}) \mathrm{i}$ opistògnat $(\mathrm{C})$. Adaptat de Gillott (2005) i de Gullan i Cranston (1994) 


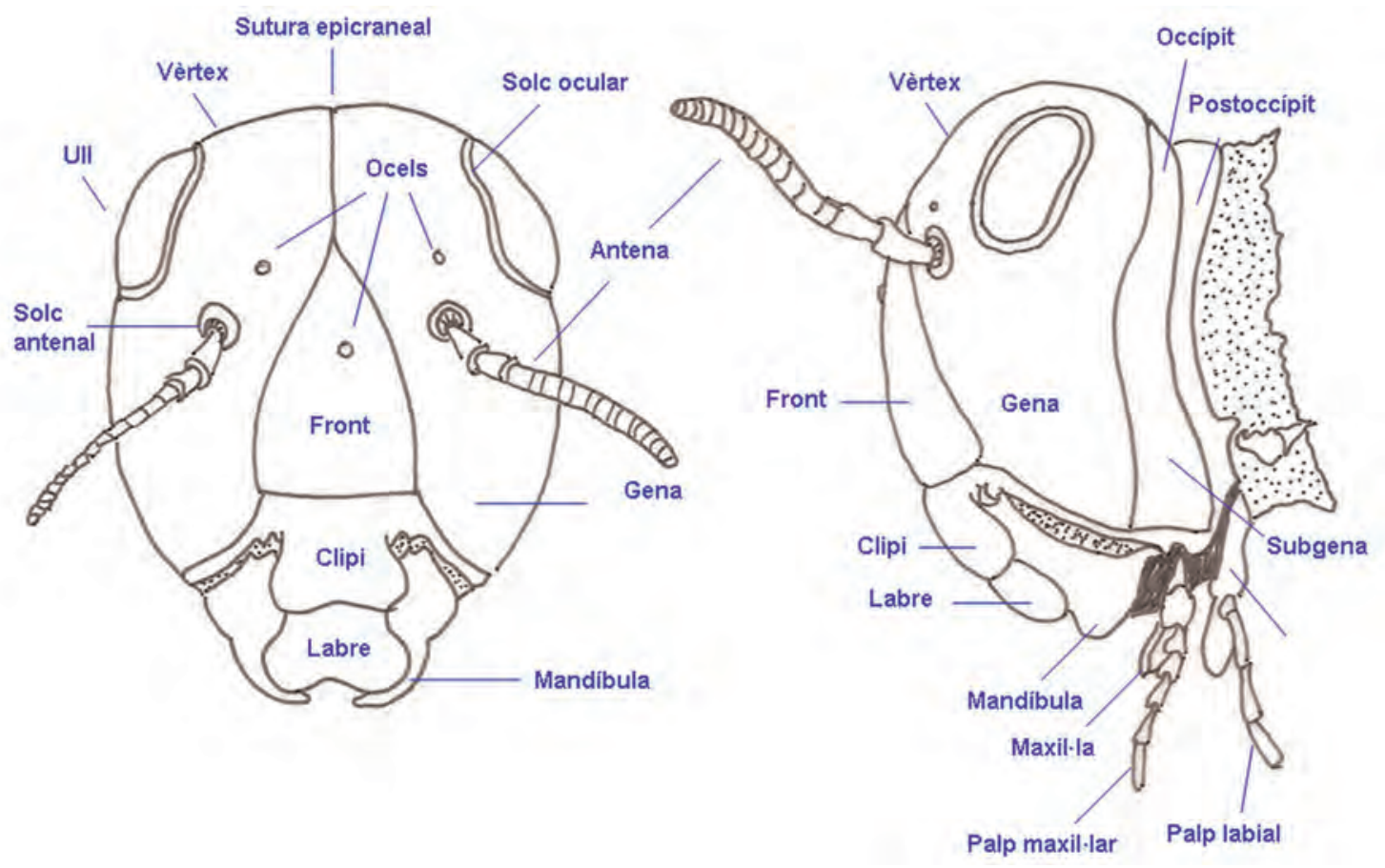

Figura 37. Parts de l'aparell bucal mastegador. Adaptat de Snodgrass (1993)

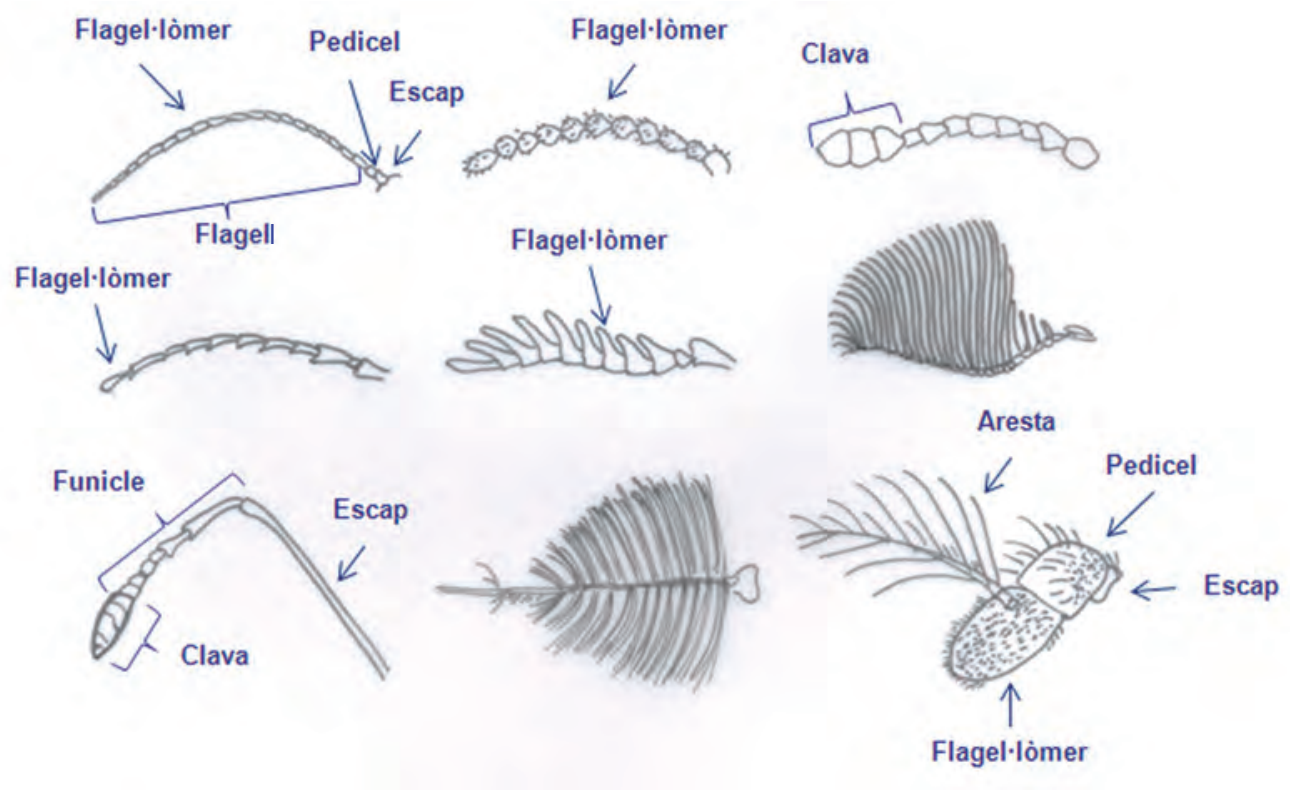

Figura 38. Tipus d'antenes. De dalt a baix i d'esquerra a dreta. $1^{\text {a }}$ fila: antena filiforme, antena moniliforme, antena claviforme; $2^{\mathrm{a}}$ fila: antena serrada, antena pectinada, antena flavel-liforme; $3^{\mathrm{a}}$ fila: antena geniculada, antena plomosa, antena arestada.

Adaptat de Gullan i Cranston (1994) 


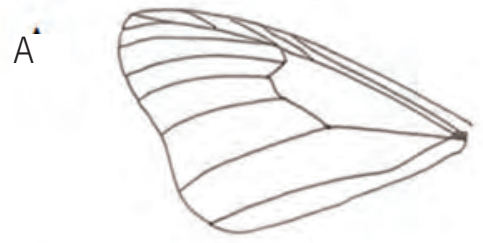

$\bar{C}$

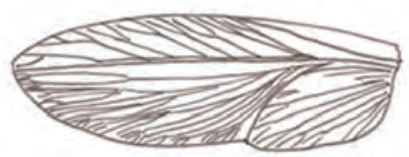

E

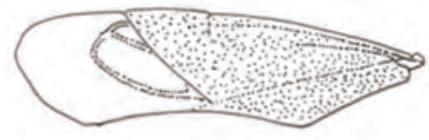

$\widetilde{B}$

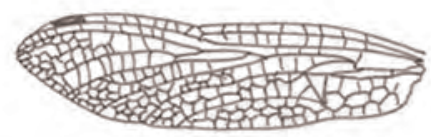

D̃

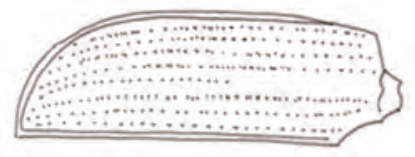

$\mathrm{F}$

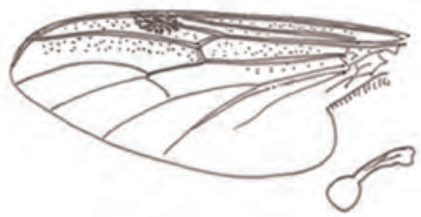

Figura 39. Tipus d'ales. A) Papallona (membranosa amb escates); B) odonat (nombroses venes transversals); C) dictiòper (tegmen); D) èlitre de coleòpter; E) hemèlitre d'un hemípter amb la part basal endurida i la distal membranosa; F) ala anterior i balancí d'un dípter. Adaptat de Gullan i Cranston (1994)

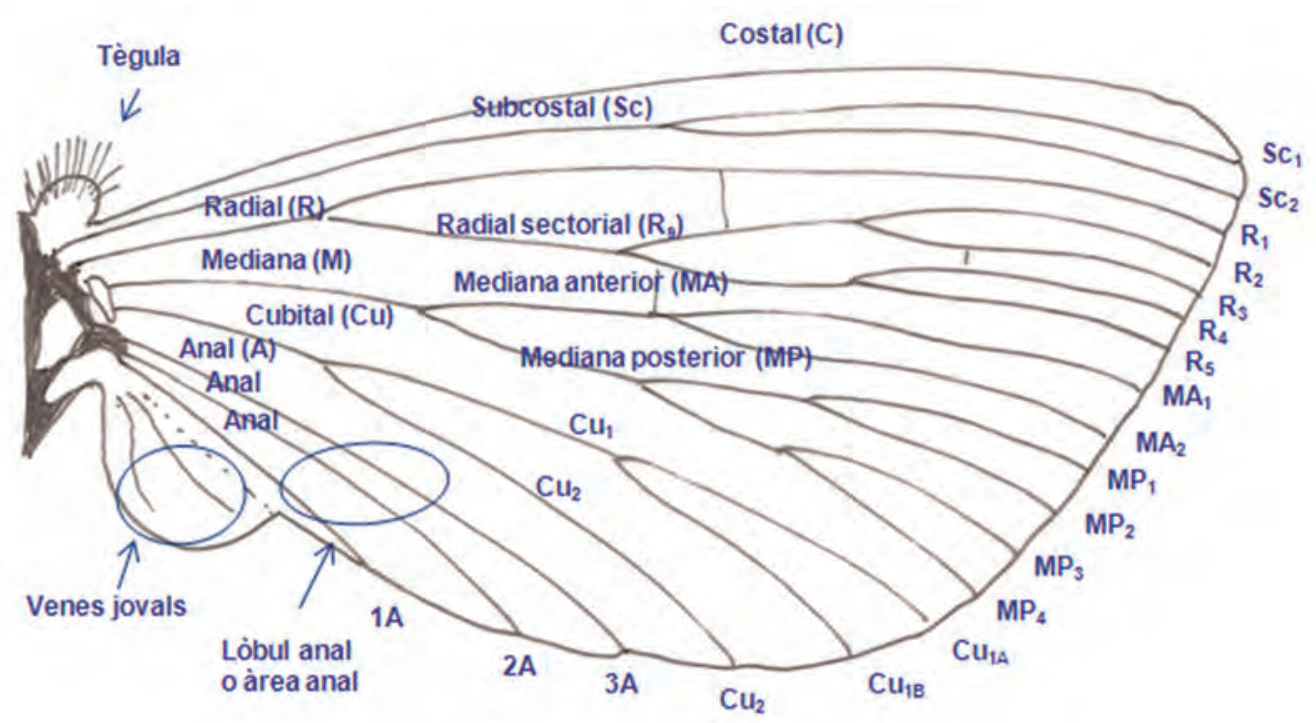

Figura 40. Principals nervis o venes de les ales. Adaptat de Gullan i Cranston (1994) 


\subsection{Clau dels ordres d'insectes}

La clau que seguirem per identificar els insectes és una adaptació de la proposada per Gillott (2005) on, a més d'identificar els adults, podem arribar a establir a quin ordre pertanyen alguns estadis immadurs.

\begin{tabular}{|c|c|c|}
\hline 1. & $\begin{array}{l}\text { Insecte amb ales ben desenvolupades. } \\
\text { Insecte sense ales (àpter), o amb ales vestigials o rudimentà- } \\
\text { ries, que no li serveixen per volar (adult o estadis immadurs } \\
\text { àpters). }\end{array}$ & $\begin{array}{c}2 \\
31\end{array}$ \\
\hline \multirow[t]{2}{*}{2.} & $\begin{array}{l}\text { Primer parell d'ales més o menys endurit (figures } 39 \mathrm{C} \text { i D), } \\
\text { almenys la part basal (figura } 39 \mathrm{E} \text { ) (de vegades molt reduït). } \\
\text { Ales posteriors membranoses (de vegades manquen). Pro- } \\
\text { tòrax ample, i no fusionat al mesotòrax (excepte en l'ordre } \\
\text { Strepsiptera). }\end{array}$ & 3 \\
\hline & Primer parell d'ales totalment membranós (figures 39A, B i F). & 11 \\
\hline \multirow[t]{2}{*}{3.} & $\begin{array}{l}\text { Primer parell d'ales amb nerviacions (figures } 39 \mathrm{C} \text { i E) o, } \\
\text { com a mínim, ales posteriors no doblegades transversalment } \\
\text { quan s'amaguen sota les anteriors. }\end{array}$ & 4 \\
\hline & $\begin{array}{l}\text { Primer parell d'ales sense nerviacions, de consistència dura } \\
\text { uniforme (figura 39D). Ales posteriors, si n'hi ha, doblega- } \\
\text { des tant transversalment com longitudinalment en repòs, } \\
\text { que s'amaguen sota les anteriors. Boca amb mandíbules. }\end{array}$ & 10 \\
\hline \multirow[t]{2}{*}{4.} & $\begin{array}{l}\text { Aparell bucal format per un rostre articulat adaptat per per- } \\
\text { forar i xuclar (figura 35F). Subordre Homoptera: primer pa- } \\
\text { rell d'ales de consistència uniforme; subordre Heteroptera: } \\
\text { primer parell d'ales amb la part basal endurida i la distal } \\
\text { membranosa (hemèlitre) (figura 39E). }\end{array}$ & Hemiptera \\
\hline & $\begin{array}{l}\text { Aparell bucal amb mandíbules adaptades per mastegar i } \\
\text { amb moviment lateral (figura 35A). }\end{array}$ & 5 \\
\hline \multirow[t]{2}{*}{5.} & $\begin{array}{l}\text { Ales posteriors no doblegades i semblants a les anteriors. } \\
\text { Part basal de l'ala endurida i molt curta i separada de la res- } \\
\text { ta de l'ala per una sutura transversal. Espècies socials que } \\
\text { viuen en colònies. Tèrmits (figura 12). }\end{array}$ & Isoptera \\
\hline & $\begin{array}{l}\text { Ales posteriors que es pleguen com un ventall, més amples } \\
\text { que les anteriors. }\end{array}$ & 6 \\
\hline \multirow[t]{2}{*}{6.} & $\begin{array}{l}\text { En general, espècies grans o moderadament grans. Antenes } \\
\text { normalment allargades i filiformes. Protòrax ample i separat } \\
\text { del mesotòrax. Amb cercs. Ales anteriors normalment llar- } \\
\text { gues; rarament diminutes. }\end{array}$ & 7 \\
\hline & $\begin{array}{l}\text { Espècies molt actives i menudes. Antenes curtes, amb pocs } \\
\text { artells, dels quals, almenys un, té un procés lateral llarg. } \\
\text { Sense cercs. Ales anteriors diminutes. Protòrax menut. In- } \\
\text { sectes rars, de vida curta, parasitoids d'altres insectes, en } \\
\text { general, de vespes i abelles (figura 29). }\end{array}$ & $\begin{array}{l}\text { Strepsiptera } \\
\text { (mascles) }\end{array}$ \\
\hline
\end{tabular}




\begin{tabular}{|c|c|c|}
\hline 7. & $\begin{array}{l}\text { Fèmurs posteriors no més amples que els fèmurs anteriors. } \\
\text { Cos més o menys aplanat, amb les ales muntades l'una so- } \\
\text { bre l'altra en repòs. Tèrgum i estern subiguals (figura 11). } \\
\text { Fèmurs posteriors gairebé sempre més amples que els fè- } \\
\text { murs anteriors (espècies saltadores). Si no, potes anteriors } \\
\text { més amples per excavar (Gryllotalpidae: grilla llauradora). } \\
\text { Cos més o menys cilíndric amb les ales inclinades contra els } \\
\text { costats en repòs. Terga en general més ample que els esterns. } \\
\text { Espècies capaces d'estridular. Saltarelles, llagostes, grills, } \\
\text { etc. (figura 6). }\end{array}$ & Orthoptera \\
\hline \multirow[t]{2}{*}{8.} & $\begin{array}{l}\text { Cos allargat. Cap lliure i visible des de dalt, que no s'amaga } \\
\text { sota el pronòtum. Espècies de moviments lents. }\end{array}$ & 9 \\
\hline & $\begin{array}{l}\text { Cos ovalat, molt aplanat. Cap pràcticament ocult sota el } \\
\text { pronòtum, que és oval. Potes idèntiques entre si amb coxes } \\
\text { grans i tíbies més o menys espinoses. Paneroles (figura } 11 \\
\text { esquerra). }\end{array}$ & $\begin{array}{c}\text { Dictyoptera } \\
\text { (S.O. Blattodea) }\end{array}$ \\
\hline \multirow[t]{2}{*}{9.} & $\begin{array}{l}\text { Protòrax molt més ample que el mesotòrax. Primer parell de } \\
\text { potes molt espinós, per agafar la presa. Cercs generalment } \\
\text { segmentats, amb més d'un artell. Pregadéus, voltacampanes } \\
\text { (figura } 11 \text { dreta). }\end{array}$ & $\begin{array}{l}\text { Dictyoptera } \\
\text { (S.O. Mantodea) }\end{array}$ \\
\hline & $\begin{array}{l}\text { Protòrax curt. Potes semblants entre si i marxadores. Cercs } \\
\text { d'un sol artell. Insectes pal i insectes fulla (figura 13). }\end{array}$ & Phasmida \\
\hline \multirow[t]{2}{*}{10.} & $\begin{array}{l}\text { Abdomen acabat en dues pinces molt quitinitzades i mòbils. } \\
\text { Antenes llargues i primes. Ales anteriors curtes, que deixen } \\
\text { al descobert bona part de l'abdomen. Ales posteriors quasi } \\
\text { circulars i fràgils, que es pleguen com un ventall en repòs. } \\
\text { Insectes allargats. Tisoretes (figura 8). }\end{array}$ & Dermaptera \\
\hline & $\begin{array}{l}\text { Abdomen no acabat en pinces. Antenes de formes diverses, } \\
\text { però gairebé sempre amb } 11 \text { artells. Ales anteriors endurides } \\
\text { (èlitres), que tapen, en general, l'abdomen. Espècies de cos } \\
\text { dur. Escarabats (figura 28). }\end{array}$ & Coleoptera \\
\hline \multirow[t]{2}{*}{11.} & Amb 2 parells d'ales. & 12 \\
\hline & $\begin{array}{l}\text { Amb un sol parell d'ales (el mesotoràcic), normalment estès } \\
\text { en repòs. }\end{array}$ & 29 \\
\hline \multirow[t]{2}{*}{12.} & $\begin{array}{l}\text { Ales llargues i molt estretes, amb molt poques venes, i } \\
\text { voltades de serrells. Tarsos d'1 a } 2 \text { artells, amb l'extrem } \\
\text { eixamplat. Peces bucals asimètriques sense mandíbules } \\
\text { mossegadores, preparades per lacerar i xuclar (aparell bucal } \\
\text { picador-xuclador). Sense cercs. Espècies diminutes. Trips } \\
\text { (figura 19). }\end{array}$ & Thysanoptera \\
\hline & $\begin{array}{l}\text { Ales més amples, en la majoria dels casos, amb venació. Si } \\
\text { les ales foren lineals, aleshores els tarsos tindrien més de } 2 \\
\text { artells i l'últim no s'eixamplaria. }\end{array}$ & 13 \\
\hline
\end{tabular}




\begin{tabular}{|c|c|c|}
\hline \multirow[t]{2}{*}{13.} & $\begin{array}{l}\text { Ales, potes i cos coberts, almenys parcialment, d'escates } \\
\text { allargades i aplanades (sovint mesclades amb pèls), que } \\
\text { gairebé sempre formen un dibuix de colors sobre les ales. } \\
\text { Aparell bucal (de vegades vestigial) en forma d'una llarga } \\
\text { llengua enrotllada formada per les maxil·les (espiritrompa), } \\
\text { adaptat per llepar. Mandíbules mossegadores presents no- } \\
\text { més en la família Micropterigidae. Palometes, borinots, pa- } \\
\text { pallones (figura 21). }\end{array}$ & Lepidoptera \\
\hline & $\begin{array}{l}\text { Ales, potes i cos no coberts d'escates, encara que de ve- } \\
\text { gades són peluts i pot trobar-s'hi alguna escata intercalada. } \\
\text { De vegades, coberts de pèls grossos, sobretot a les potes. } \\
\text { En alguns casos, coberts d'un polsim o làmines ceroses. El } \\
\text { disseny de colors, quan n'hi ha, s'estén per la membrana de } \\
\text { l'ala. }\end{array}$ & 14 \\
\hline \multirow[t]{2}{*}{14.} & $\begin{array}{l}\text { Ales posteriors amb l'àrea anal ben separada, que es plega } \\
\text { com un ventall en repòs, normalment més ampla i gran que } \\
\text { les anteriors (figures } 9 \text { i 40). Venació alar abundosa. Antenes } \\
\text { molt aparents. }\end{array}$ & 15 \\
\hline & $\begin{array}{l}\text { Ales posteriors sense àrea anal separada; no són mai més } \\
\text { grans que les anteriors i no es pleguen en repòs. }\end{array}$ & 17 \\
\hline \multirow[t]{2}{*}{15.} & Tarsos de 5 artells. Cercs poc aparents. & 16 \\
\hline & $\begin{array}{l}\text { Tarsos de } 3 \text { artells. Cercs, normalment, llargs i plurisegmen- } \\
\text { tats. Protòrax gran i lliure. Espècies de grandària moderada } \\
\text { a gran. Perles, mosques d'aigua o de les pedres (figura 9). }\end{array}$ & Plecoptera \\
\hline \multirow[t]{2}{*}{16.} & $\begin{array}{l}\text { Ales amb venes transversals subcostals. Protòrax bastant } \\
\text { gran. Espècies de mida moderada a gran (figura 26). }\end{array}$ & Megaloptera \\
\hline & $\begin{array}{l}\text { Ales sense venes transversals subcostals, cobertes de pèls. } \\
\text { Protòrax petit. Espècies de grandària menuda o mitjana. Fri- } \\
\text { gànies (figura 22). }\end{array}$ & Trichoptera \\
\hline \multirow[t]{2}{*}{17.} & $\begin{array}{l}\text { Antenes curtes i poc aparents. Ales amb moltes venes trans- } \\
\text { versals. Aparell bucal mastegador (figura 35A). }\end{array}$ & 18 \\
\hline & $\begin{array}{l}\text { Antenes grans. Si les antenes foren menudes, aleshores o bé } \\
\text { les venes tindrien poques venes transversals, o bé l'aparell } \\
\text { bucal seria un rostre xuclador segmentat (figures 18A i B i } \\
35 \mathrm{~F} \text { ). }\end{array}$ & 19 \\
\hline \multirow[t]{2}{*}{18.} & $\begin{array}{l}\text { Ales posteriors molt més xicotetes que les anteriors. Abdo- } \\
\text { men acabat en llargs processos filamentosos. Tarsos de } 4 \text { a } 5 \\
\text { artells. Voladors lents. Efímeres (figura 4). }\end{array}$ & Ephemeroptera \\
\hline & $\begin{array}{l}\text { Ales posteriors semblants a les anteriors. Sense seda caudal. } \\
\text { Tarsos de } 3 \text { artells. Espècies sovint grosses, voladores actives } \\
\text { i vigoroses. Parotets, libèlllules, pixavins (figura 5). }\end{array}$ & Odonata \\
\hline \multirow[t]{2}{*}{19.} & $\begin{array}{l}\text { Cap prolongat ventralment, que forma un rostre, a l'extrem } \\
\text { del qual es troba la boca mastegadora. Ales normalment } \\
\text { amb dibuixos de colors i moltes venes transversals. Les ales } \\
\text { posteriors no es pleguen. Els mascles presenten el segment } \\
\text { genital unflat formant un bulb. Mosques escorpí (figura 20). }\end{array}$ & Mecoptera \\
\hline & Insectes que no reuneixen els caràcters anteriors. & 20 \\
\hline
\end{tabular}




\begin{tabular}{|c|c|c|}
\hline \multirow[t]{2}{*}{20.} & $\begin{array}{l}\text { Aparell bucal picador-xuclador o llepador, que pot ser rudi- } \\
\text { mentari, pot mancar o tenir llargs pèls (figures } 35 \mathrm{~B} \text {, C, E i } \\
\text { F). Sense cercs. Ales amb poques venes transversals. }\end{array}$ & 21 \\
\hline & $\begin{array}{l}\text { Aparell bucal mastegador (figura 35A) (ocasionalment lle- } \\
\text { pador en Hymenoptera superiors, figura 35D). Mandíbules } \\
\text { sempre presents i amb la forma mastegadora típica. }\end{array}$ & 22 \\
\hline \multirow[t]{2}{*}{21.} & $\begin{array}{l}\text { Ales, sense escates, no esteses en repòs. Protòrax llarg. An- } \\
\text { tenes amb pocs artells. Aparell bucal compost d'un rostre } \\
\text { picador-xuclador segmentat (figura 18). }\end{array}$ & Hemiptera \\
\hline & $\begin{array}{l}\text { Ales i cos coberts amb escates de colors que formen un di- } \\
\text { buix definit a les ales. Antenes plurisegmentades. Aparell } \\
\text { bucal, si no ha desaparegut, en espiritrompa, adaptat per lle- } \\
\text { par. Palometes, borinots, papallones (figura 21). }\end{array}$ & Lepidoptera \\
\hline \multirow[t]{2}{*}{22.} & $\begin{array}{l}\text { Tarsos de } 5 \text { artells. Excepcionalment, poden presentar-ne } 3 \\
\text { o } 4 \text {, però en aquest cas, les ales posteriors són més xicotetes } \\
\text { que les anteriors i es col-loquen en repòs horitzontalment } \\
\text { sobre el cos. No tenen cercs. }\end{array}$ & 23 \\
\hline & Tarsos de 2, 3 o 4 artells. Ales amb venació escassa. & 26 \\
\hline \multirow[t]{2}{*}{23.} & $\begin{array}{l}\text { Protòrax menut o moderadament llarg, excepte en Mantis- } \\
\text { pidae (figura } 25 \mathrm{C} \text { ), on és molt llarg, però en aquest cas el } \\
\text { primer parell de potes és raptor. }\end{array}$ & 24 \\
\hline & $\begin{array}{l}\text { Protòrax molt llarg i cilíndric, més llarg que el cap. Potes } \\
\text { anteriors normals. Antenes amb més d'11 artells. Ales amb } \\
\text { moltes venes transversals. Rafídies (figura 27). }\end{array}$ & Raphidioptera \\
\hline \multirow[t]{2}{*}{24.} & $\begin{array}{l}\text { Ales similars, amb venació abundosa. Protòrax més o menys } \\
\text { lliure. }\end{array}$ & 25 \\
\hline & $\begin{array}{l}\text { Ales amb poques cel·les angulars relativament. Cel·la costal } \\
\text { sense venes transversals. Ales posteriors més menudes que } \\
\text { les anteriors. Protòrax fusionat amb el mesotòrax. Abdomen } \\
\text { sovint comprimit basalment (cintura de vespa) i acabat en } \\
\text { un fibló o ovipositor especialitzat. Formigues, vespes, abe- } \\
\text { lles (figura 30). }\end{array}$ & Hymenoptera \\
\hline \multirow[t]{2}{*}{25.} & $\begin{array}{l}\text { Cel·la costal, almenys a les ales anteriors, generalment amb } \\
\text { nombroses venes transversals. Formigues lleó, crisopes, he- } \\
\text { meròbids, conwèntzies (figures } 25 \mathrm{~B} \mathrm{i} \mathrm{C).}\end{array}$ & Neuroptera \\
\hline & $\begin{array}{l}\text { Cel·la costal sense venació transversal. Mosques escorpí (fi- } \\
\text { gura 20). }\end{array}$ & Mecoptera \\
\hline \multirow[t]{2}{*}{26.} & $\begin{array}{l}\text { Ales de la mateixa grandària (excepcionalment, les posteriors } \\
\text { poden ser més amples), que en repòs queden superposades } \\
\text { sobre l'abdomen. Vena mediana breument unida a la radial } \\
\text { sectorial en la zona central de l'ala. Tarsos de } 3,4 \text { o } 5 \text { artells. }\end{array}$ & 27 \\
\hline & $\begin{array}{l}\text { Ales posteriors més menudes que les anteriors. En repòs, les } \\
\text { ales es pleguen cap enrere contra l'abdomen. Venes radial i } \\
\text { mediana que mai no s'uneixen. Tarsos de } 2 \text { o } 3 \text { artells. }\end{array}$ & 28 \\
\hline \multirow[t]{2}{*}{27.} & $\begin{array}{l}\text { Tarsos de } 4 \text { artells, aparentment. Cercs, en general, dimi- } \\
\text { nuts. Ales amb una sutura transversal prop de la base. Espè- } \\
\text { cies socials que viuen en colònies. Tèrmits (figura 12). }\end{array}$ & Isoptera \\
\hline & $\begin{array}{l}\text { Tarsos de } 3 \text { artells. Metatars anterior eixamplat. Cercs apa- } \\
\text { rents. Espècies normalment solitàries. Teixidors (figura 10). }\end{array}$ & Embioptera \\
\hline
\end{tabular}




\begin{tabular}{|c|c|c|}
\hline \multirow[t]{2}{*}{28.} & $\begin{array}{l}\text { Sense cercs. Tarsos de } 2 \text { o } 3 \text { artells. Ales permanentment } \\
\text { unides. Venes radial, sectorial i mitjana ramificades, excepte } \\
\text { quan les ales anteriors estan molt eixamplades. Polls dels } \\
\text { llibres (figura 16). }\end{array}$ & Psocoptera \\
\hline & $\begin{array}{l}\text { Amb cercs. Tarsos de } 2 \text { artells. Ales que es perden en arribar } \\
\text { a la maduresa. Venació alar molt reduïda. Venes radial, sec- } \\
\text { torial i mitjana no ramificades (figura 15). }\end{array}$ & Zoraptera \\
\hline \multirow[t]{2}{*}{29.} & $\begin{array}{l}\text { Aparell bucal no funcional. Abdomen amb } 2 \text { filaments cau- } \\
\text { dals o cercs (figura 4). }\end{array}$ & 30 \\
\hline & $\begin{array}{l}\text { Aparell bucal format per una proboscis, adaptada per lle- } \\
\text { par. Excepcionalment pot ser vestigial. Abdomen sense fi- } \\
\text { laments caudals. Ales posteriors transformades en balancins } \\
\text { globosos. Mosques (figura 23). }\end{array}$ & Diptera \\
\hline \multirow[t]{2}{*}{30.} & $\begin{array}{l}\text { Sense balancins. Antenes poc aparents. Ales amb moltes ve- } \\
\text { nes transversals. Efímeres (figura 4). }\end{array}$ & Ephemeroptera \\
\hline & $\begin{array}{l}\text { Ales posteriors transformades en minúsculs balancins en } \\
\text { forma de ganxo. Ales anteriors amb la venació reduïda a una } \\
\text { vena bifurcada i sense venes transversals. Antenes aparents. } \\
\text { Diminuts i delicats. Mascles de Coccoidea (figura 18J). }\end{array}$ & Hemiptera \\
\hline \multirow[t]{2}{*}{31.} & $\begin{array}{l}\text { Cos amb cap, tòrax i abdomen més o menys diferenciats. } \\
\text { Potes articulades. Insectes capaços de desplaçar-se. }\end{array}$ & 32 \\
\hline & $\begin{array}{l}\text { Cos indiferenciat i sense potes articulades. Insectes, en ge- } \\
\text { neral, incapaços de desplaçar-se. Sovint, coberts amb secre- } \\
\text { cions cèries. Coccoideus (polls, caparretes, cotonets, etc) } \\
\text { (figures } 18 \mathrm{H} \mathrm{i} \mathrm{I).}\end{array}$ & 75 \\
\hline \multirow[t]{3}{*}{32.} & $\begin{array}{l}\text { Terrestres, que respiren per espiracles. Molt sovint amb òr- } \\
\text { gans respiratoris especials. }\end{array}$ & 33 \\
\hline & $\begin{array}{l}\text { Aquàtiques, normalment amb respiració branquial, formes } \\
\text { larvàries. }\end{array}$ & 62 \\
\hline & Espècies paràsites d'animals de sang calenta. & 70 \\
\hline \multirow[t]{2}{*}{33.} & $\begin{array}{l}\text { Aparell bucal retret a l'interior del cap, difícilment visible. } \\
\text { Abdomen amb estils o altres apèndixs en la seua part ven- } \\
\text { tral. Si tenen antenes, aleshores els palps maxil·lars tenen } \\
\text { menys de } 3 \text { artells. Insectes menuts o diminuts. }\end{array}$ & 34 \\
\hline & $\begin{array}{l}\text { Aparell bucal clarament visible externament. Si l'aparell } \\
\text { bucal és mandibulat, els palps maxil-lars tenen més de } 2 \text { ar- } \\
\text { tells. Antenes sempre presents. Excepcionalment, abdomen } \\
\text { amb estils a la part ventral. }\end{array}$ & 36 \\
\hline \multirow[t]{2}{*}{34.} & $\begin{array}{l}\text { Sense antenes. Abdomen sense cercs llargs, ni pinces, ni } \\
\text { aparell de salt, ni tub succionador ventral. Cap piriforme. }\end{array}$ & $\begin{array}{l}\text { Protura } \\
\text { (Classe) }\end{array}$ \\
\hline & $\begin{array}{l}\text { Antenes ben visibles. Abdomen amb cercs llargs, pinces o } \\
\text { tub succionador ventral. }\end{array}$ & 35 \\
\hline \multirow[t]{2}{*}{35.} & $\begin{array}{l}\text { Abdomen amb } 6 \text { segments com a màxim, que porta en la } \\
\text { base un tub ventral succionador bifurcat. Sense pinces ni } \\
\text { llargs cercs terminals. En general amb un aparell saltador } \\
\text { prop del final de l'abdomen. }\end{array}$ & $\begin{array}{l}\text { Collembola } \\
\text { (Classe) }\end{array}$ \\
\hline & $\begin{array}{l}\text { Abdomen amb més de } 8 \text { segments visibles, que acaba o bé } \\
\text { en cercs llargs plurisegmentats, o bé en unes pinces robus- } \\
\text { tes. Sense ulls ni ocels. }\end{array}$ & $\begin{array}{l}\text { Diplura } \\
\text { (Classe) }\end{array}$ \\
\hline
\end{tabular}




\begin{tabular}{|c|c|c|}
\hline \multirow[t]{2}{*}{36.} & Aparell bucal mastegador. & 37 \\
\hline & Aparell bucal xuclador. & 59 \\
\hline \multirow[t]{2}{*}{37.} & $\begin{array}{l}\text { Cos normalment cobert d'escates. Abdomen amb } 3 \text { fila- } \\
\text { ments caudals i almenys } 2 \text { parells d'estils ventrals. }\end{array}$ & 38 \\
\hline & $\begin{array}{l}\text { Cos mai cobert d'escates ni amb } 3 \text { filaments caudals. Estils } \\
\text { ventrals absents en l'abdomen. }\end{array}$ & 39 \\
\hline \multirow[t]{2}{*}{38.} & $\begin{array}{l}\text { Cap amb gran ulls compostos i ocels. Potes amb } 3 \text { artells en } \\
\text { el tars. Un parell d'estils presents en cada segment abdomi- } \\
\text { nal. Peixets de coure (figura } 3 \text { esquerra). }\end{array}$ & Microcoryphia \\
\hline & $\begin{array}{l}\text { Ulls compostos menuts o absents. Potes amb } 2 \text { o } 4 \text { artells } \\
\text { en el tars. Un parell d'estils en els segments abdominals 7-9 } \\
\text { (rara vegada en el 2-9). Peixets de plata (figura } 3 \text { dreta). }\end{array}$ & Zygentoma \\
\hline \multirow[t]{2}{*}{39.} & Abdomen sense potes. & 40 \\
\hline & $\begin{array}{l}\text { Abdomen amb falses potes diferents de les toràciques. Cos } \\
\text { en forma d'eruga, cilíndric. Tòrax i abdomen no separats } \\
\text { clarament. Formes larvàries (figura 21E). }\end{array}$ & 57 \\
\hline \multirow[t]{2}{*}{40.} & Antenes llargues. & 41 \\
\hline & Antenes curtes i no pronunciades. Formes larvàries. & 54 \\
\hline \multirow[t]{2}{*}{41.} & $\begin{array}{l}\text { Abdomen acabat en } 2 \text { fortes pinces mòbils. Protòrax lliure. } \\
\text { Tisoretes, cuca-talles, papasastres (figura 8). }\end{array}$ & Dermaptera \\
\hline & Abdomen no acabat en pinces. & 42 \\
\hline \multirow[t]{2}{*}{42.} & $\begin{array}{l}\text { Abdomen molt comprimit a la base (cintura de vespa). Protò- } \\
\text { rax unit al mesotòrax. Formigues, abelles, vespes (figura 30). }\end{array}$ & Hymenoptera \\
\hline & $\begin{array}{l}\text { Abdomen no comprimit a la base, unit al tòrax sense estrè- } \\
\text { nyer-se considerablement. }\end{array}$ & 43 \\
\hline \multirow[t]{2}{*}{43.} & Cap no prolongat ventralment. & 44 \\
\hline & $\begin{array}{l}\text { Cap prolongat ventralment en un rostre al final del qual es } \\
\text { troben les peces bucals mastegadores. Mosques escorpí (fi- } \\
\text { gura 20). }\end{array}$ & Mecoptera \\
\hline \multirow[t]{2}{*}{44.} & $\begin{array}{l}\text { Espècies molt menudes de cos moll i dèbilment esclerotit- } \\
\text { zat. Tarsos de } 2 \text { o } 3 \text { artells. }\end{array}$ & 45 \\
\hline & $\begin{array}{l}\text { Espècies, en general, de més grandària. Tarsos normalment } \\
\text { amb més de } 3 \text { artells. En cas contrari, el cos és dur i forta- } \\
\text { ment esclerotitzat i no té cercs. }\end{array}$ & 46 \\
\hline \multirow[t]{2}{*}{45.} & Sense cercs. Polls dels llibres (figura 16). & Psocoptera \\
\hline & Amb cercs aparents, no segmentats (figura 15). & Zoraptera \\
\hline \multirow[t]{2}{*}{46.} & $\begin{array}{l}\text { Fèmurs posteriors més grossos que els anteriors (figura 6). } \\
\text { Si els esbossos alars de la nimfa estan presents, es troben en } \\
\text { posició inversa, és a dir, els metatoràcics solapant els meso- } \\
\text { toràcics. }\end{array}$ & Orthoptera \\
\hline & $\begin{array}{l}\text { Fèmurs posteriors normals, no engrandits per botar. Si es } \\
\text { troben esbossos alars, aquests estan en la posició normal. }\end{array}$ & 47 \\
\hline \multirow[t]{2}{*}{47.} & $\begin{array}{l}\text { Protòrax molt més llarg que el mesotòrax. Potes anteriors } \\
\text { raptores. Pregadéus, mantis (figura } 11 \text { dreta). }\end{array}$ & $\begin{array}{c}\text { Dictyoptera } \\
\text { (Subordre Mantodea) }\end{array}$ \\
\hline & Protòrax no molt allargat. & 48 \\
\hline \multirow[t]{2}{*}{48.} & Amb cercs. Antenes, en general, de més de 15 artells. & 49 \\
\hline & $\begin{array}{l}\text { En general, sense cercs. Cos sovint protegit per una cuirassa. } \\
\text { Antenes normalment d'11 artells. Escarabats (figura 28). }\end{array}$ & Coleoptera \\
\hline
\end{tabular}




\begin{tabular}{|c|c|c|}
\hline \multirow[t]{2}{*}{49.} & Cercs amb més de 3 artells. & 50 \\
\hline & Cercs curts, d'1 a 3 artells. & 52 \\
\hline \multirow[t]{2}{*}{50.} & $\begin{array}{l}\text { Cos aplanat i ovalat. Cap flexionat. Protòrax ovalat. Panero- } \\
\text { les (figura } 11 \text { esquerra). }\end{array}$ & $\begin{array}{c}\text { Dictyoptera } \\
\text { (Subordre Blattodea) }\end{array}$ \\
\hline & Cos allargat. Cap gairebé horitzontal & 53 \\
\hline \multirow[t]{2}{*}{51.} & $\begin{array}{l}\text { Cercs llargs. Tarsos de } 5 \text { artells. Ovipositor prolongat més } \\
\text { enllà del cos i rígid (figura 7). }\end{array}$ & Grylloblattodea \\
\hline & $\begin{array}{l}\text { Cercs curts. Tarsos de } 4 \text { artells. Sense ovipositor. Insectes } \\
\text { socials que viuen en colònies. Tèrmits (figura 12). }\end{array}$ & Isoptera \\
\hline \multirow[t]{2}{*}{52.} & $\begin{array}{l}\text { Tarsos de } 5 \text { artells. Cos, en general molt estret i allargat. } \\
\text { Insectes pal, insectes fulla (figura 13). }\end{array}$ & Phasmida \\
\hline & Tarsos de 2 a 3 artells. Cos no allargat. & 51 \\
\hline \multirow[t]{2}{*}{53.} & $\begin{array}{l}\text { Tarsos de les potes anteriors amb el primer artell molt gros, } \\
\text { que porta una glàndula productora de seda que serveix a } \\
\text { l'insecte per a produir la teranyina on viu. Cos llarg i prim. } \\
\text { Teixidors (figura 10). }\end{array}$ & Embioptera \\
\hline & $\begin{array}{l}\text { Insecte que no reuneix els caràcters anteriors. Cos més ro- } \\
\text { bust. Espècies socials. Tèrmits (figura 12). }\end{array}$ & Isoptera \\
\hline \multirow[t]{2}{*}{54.} & Cos cilíndric, erugues. & 55 \\
\hline & Cos més o menys aplanat, no erugues. & 56 \\
\hline \multirow[t]{2}{*}{55.} & $\begin{array}{l}\text { Cap amb } 6 \text { ocels a cada costat. Llavi amb un òrgan per pro- } \\
\text { duir seda. Antenes inserides dins d'una àrea membranosa a } \\
\text { la base de les mandíbules. }\end{array}$ & $\begin{array}{l}\text { Larves d'alguns } \\
\text { Lepidoptera }\end{array}$ \\
\hline & $\begin{array}{l}\text { Cap amb més de } 6 \text { ocels a cada costat. Potes metatoràciques } \\
\text { més llargues que les protoràciques. }\end{array}$ & $\begin{array}{c}\text { Mecoptera } \\
\text { (Larves de Boreidae) }\end{array}$ \\
\hline \multirow[t]{2}{*}{56.} & $\begin{array}{l}\text { Mandíbules unides a les maxil·les per formar un òrgan xu- } \\
\text { clador (figura } 25 \mathrm{~A} \text { ). }\end{array}$ & $\begin{array}{c}\text { Neuroptera } \\
\text { (Larves) }\end{array}$ \\
\hline & Mandíbules separades de les maxil·les. & $\begin{array}{l}\text { Coleoptera, Raphidioptera, } \\
\text { Strepsiptera i Diptera } \\
\text { (Larves) }\end{array}$ \\
\hline \multirow[t]{2}{*}{57.} & $\begin{array}{l}5 \text { parells de falses potes o menys, localitzades en alguns seg- } \\
\text { ments abdominals, excepte en el primer, segon o setè, i aca- } \\
\text { bades en molts i minúsculs ganxos (rara vegada potes falses } \\
\text { sense ganxos en el segon i en el setè segments). }\end{array}$ & $\begin{array}{l}\text { Larves de la majoria de } \\
\text { Lepidoptera }\end{array}$ \\
\hline & $\begin{array}{l}\text { De } 6 \text { a } 10 \text { parells de potes abdominals, un dels quals apareix } \\
\text { en el segon segment abdominal. Falses potes no acabades } \\
\text { en ganxos. }\end{array}$ & 58 \\
\hline \multirow[t]{2}{*}{58.} & Cap amb un únic ocel en cada costat. & $\begin{array}{l}\text { Larves d'alguns } \\
\text { Hymenoptera }\end{array}$ \\
\hline & Cap amb diversos ocels en cada costat. & $\begin{array}{c}\text { Mecoptera } \\
\text { (Larves) }\end{array}$ \\
\hline \multirow[t]{2}{*}{59.} & Cos nu, o amb pocs pèls dispersos, o amb recobriment cerós. & 60 \\
\hline & $\begin{array}{l}\text { Cos densament cobert de pèls o escates. Proboscis, quan n'hi } \\
\text { ha, enrotllada sota el cap. Palometes, borinots (figura 21). }\end{array}$ & Lepidoptera \\
\hline \multirow[t]{2}{*}{60.} & $\begin{array}{l}\text { Últim artell del tars eixamplat. Aparell bucal que forma un } \\
\text { rostre triangular, curt, sense segmentar. Espècies molt me- } \\
\text { nudes. Trips (figura 19). }\end{array}$ & Thysanoptera \\
\hline & Tars no eixamplat en la punta i amb ungles visibles. & 61 \\
\hline
\end{tabular}




\begin{tabular}{|c|c|c|}
\hline 61. & $\begin{array}{l}\text { Protòrax molt desenvolupat (figura 18). } \\
\text { Protòrax menut, que no és visible quan es mira l'insecte dor- } \\
\text { salment (figura 23). }\end{array}$ & $\begin{array}{l}\text { Hemiptera } \\
\text { Diptera }\end{array}$ \\
\hline 62. & $\begin{array}{l}\text { Peces bucals mastegadores. } \\
\text { Peces bucals xucladores, amb un fort bec en punta i doble- } \\
\text { gat. }\end{array}$ & $\begin{array}{c}63 \\
\text { Hemiptera } \\
\text { (Larves) }\end{array}$ \\
\hline 63. & $\begin{array}{l}\text { Mandíbules projectades cap a fora i rectes, unides a les maxil- } \\
\text { les per formar unes peces bucals perforadores (figura 25A). } \\
\text { Mandíbules normals, amb moviment lateral per funcionar } \\
\text { com a mandíbula mossegadora. }\end{array}$ & $\begin{array}{l}\text { Neuroptera } \\
\text { (Larves) } \\
64\end{array}$ \\
\hline 64. & $\begin{array}{l}\text { Cos no tancat en un estoig fet de terra, pedretes i fulles. } \\
\text { Formes portadores d'estoig (figura 22). Tràquees normal- } \\
\text { ment presents. }\end{array}$ & $\begin{array}{c}65 \\
\text { Trichoptera } \\
\text { (Larves) }\end{array}$ \\
\hline 65. & $\begin{array}{l}\text { Abdomen amb tràquees laterals externes (algunes larves de } \\
\text { Coleoptera i Trichoptera). } \\
\text { Abdomen sense tràquees. }\end{array}$ & 67 \\
\hline 66. & $\begin{array}{l}\text { Abdomen acabat en } 2 \text { o } 3 \text { filaments caudals (figura } 4 \text { dreta). } \\
\text { Abdomen amb processos caudals curts. }\end{array}$ & $\begin{array}{l}\text { Ephemeroptera } \\
\text { (Larves) } \\
\text { Megaloptera } \\
\text { (Larves) }\end{array}$ \\
\hline 67. & $\begin{array}{l}\text { Llavi fort, extensible i provist amb un parell de ganxos opo- } \\
\text { sats. } \\
\text { Llavi no extensible i sense ganxos. }\end{array}$ & $\begin{array}{c}\text { Odonata } \\
\text { (Larves) } \\
68\end{array}$ \\
\hline 68. & $\begin{array}{l}\text { Abdomen sense falses potes. } \\
\text { Abdomen amb un parell de falses potes en diversos seg- } \\
\text { ments. }\end{array}$ & $\begin{array}{c}69 \\
\text { Algunes larves } \\
\text { de Lepidoptera }\end{array}$ \\
\hline 69. & $\begin{array}{l}\text { Les } 3 \text { divisions del tòrax dèbilment unides; filaments ante- } \\
\text { nals i caudals llargs i estrets (figura } 9 \text { dreta). } \\
\text { Divisions toràciques no marcades; filaments antenals i caudals } \\
\text { curts (també algunes larves aquàtiques de Diptera i Trichoptera). }\end{array}$ & $\begin{array}{l}\text { Plecoptera } \\
\text { (Larves) } \\
\text { Coleoptera } \\
\text { (Larves) }\end{array}$ \\
\hline 70. & $\begin{array}{l}\text { Cos aixafat. } \\
\text { Cos molt comprimit lateralment. Aparell bucal que forma } \\
\text { un rostre afilat i doblegat adaptat per picar i xuclar. Espècies } \\
\text { saltadores. Puces (figura 24). }\end{array}$ & $\begin{array}{c}57 \\
\text { Siphonaptera }\end{array}$ \\
\hline 71. & $\begin{array}{l}\text { Aparell bucal mastegador. } \\
\text { Aparell bucal picador-xuclador }\end{array}$ & $\begin{array}{l}72 \\
73\end{array}$ \\
\hline 72. & $\begin{array}{l}\text { Cap hipògnat. Cercs llargs. Ectoparàsits de rates penades i } \\
\text { rosegadors. } \\
\text { Cap prògnat. Sense cercs. Forma ovalada-allargada, en gene- } \\
\text { ral amb el cap lleugerament triangular. Ectoparàsits d'ocells } \\
\text { (ocasionalment de mamífers). Polls de les aus (figura 17). }\end{array}$ & $\begin{array}{c}\text { Alguns Dermaptera } \\
\text { Phthiraptera }\end{array}$ \\
\hline 73. & $\begin{array}{l}\text { Antenes curtes, però visibles. } \\
\text { Antenes inserides en una fossa, que no es veuen des de dalt. } \\
\text { Larves de dípters. Mosques. }\end{array}$ & $\begin{array}{c}74 \\
\text { Diptera pupípara }\end{array}$ \\
\hline 74. & $\begin{array}{l}\text { Aparell bucal en rostre no segmentat. Tarsos acabats en un } \\
\text { ganxo que serveix per agafar-se als pèls de l'hoste. Paràsits } \\
\text { permanents. Polls i llèmenes (figura 17). } \\
\text { Aparell bucal en rostre segmentat. Tarsos sense ganxos. Pa- } \\
\text { ràsits temporals. Xinxes (figura 18). }\end{array}$ & Phthiraptera \\
\hline
\end{tabular}




\begin{tabular}{|c|c|c|}
\hline 75. & $\begin{array}{l}\text { Larves àpodes, larves de dípters o minadores; locomoció } \\
\text { afectada per moviments de torsió. }\end{array}$ & $\begin{array}{l}\text { Larves de Strepsiptera, } \\
\text { Siphonaptera, alguns } \\
\text { Coleoptera, Diptera, } \\
\text { Lepidoptera i Hymenoptera } \\
76\end{array}$ \\
\hline \multirow[t]{2}{*}{76.} & $\begin{array}{l}\text { Formes menudes que no semblen insectes, amb el rostre } \\
\text { llarg i prim, i normalment cobertes de substàncies cèries, } \\
\text { polsim o estructures amb aspecte de cotó (figura 18H). Vi- } \\
\text { uen en diverses plantes. Cotxinilles. }\end{array}$ & Hemiptera \\
\hline & $\begin{array}{l}\text { Cos quiescent, però capaç de doblegar-se lateralment. Inca- } \\
\text { paç d'alimentar-se ja que està tancat dins d'una cutícula que } \\
\text { uneix fermament tots els apèndixs o que en deixa alguns de } \\
\text { lliures però plegats contra el cos. Algunes vegades es troba } \\
\text { lliure mentre que altres està tancat dins d'un capoll o coberta } \\
\text { formada amb les mudes larvàries seques. }\end{array}$ & 77 \\
\hline \multirow[t]{2}{*}{77.} & $\begin{array}{l}\text { La cutícula cobreix les potes, ales, etc., i manté els apèndixs } \\
\text { fermament units contra el cos. Protòrax menut. Proboscis } \\
\text { visible. }\end{array}$ & 78 \\
\hline & $\begin{array}{l}\text { Potes, ales, etc., més o menys lliures del cos. Peces bucals } \\
\text { mastegadores visibles. }\end{array}$ & 79 \\
\hline \multirow[t]{2}{*}{78.} & $\begin{array}{l}\text { Proboscis normalment llarga, rarament absent. Quatre es- } \\
\text { toigs alars. Algunes vegades es troba dins d'un capoll (fi- } \\
\text { gura 21F). }\end{array}$ & $\begin{array}{l}\text { Lepidoptera } \\
\text { (Pupes) }\end{array}$ \\
\hline & $\begin{array}{l}\text { Proboscis curta. Dos estoigs alars. Pupa amb freqüència tan- } \\
\text { cada en una coberta ovalada (pupari) formada amb el tegu- } \\
\text { ment endurit de la larva (figura 23F). }\end{array}$ & $\begin{array}{l}\text { Diptera } \\
\text { (Pupes) }\end{array}$ \\
\hline \multirow[t]{2}{*}{79.} & $\begin{array}{l}\text { Protòrax menut, unit en una sola peça amb el mesotòrax. Al- } \\
\text { gunes vegades es troba dins d'un capoll una mica deslligat. }\end{array}$ & $\begin{array}{l}\text { Hymenoptera } \\
\text { (Pupes) }\end{array}$ \\
\hline & Protòrax gran i no fortament unit al mesotòrax. & 80 \\
\hline \multirow[t]{2}{*}{80.} & Estoig alar amb poques venes o sense venes (figura 28B). & $\begin{array}{l}\text { Coleoptera } \\
\text { (Pupes) }\end{array}$ \\
\hline & Estoig alar amb diverses branques ramificades & $\begin{array}{l}\text { Neuroptera } \\
\text { (Pupes) }\end{array}$ \\
\hline
\end{tabular}

\section{Objectius de la pràctica}

Els objectius d'aquesta pràctica es concreten en tres:

1. Familiaritzar-se amb la morfologia dels insectes: tipus d'aparells bucals, d'ales, de potes, etc.

2. Aprendre a utilitzar la lupa binocular.

3. Identificar alguns dels ordres d'insectes més importants des del punt de vista agronòmic. 


\section{Desenvolupament de la pràctica}

\subsection{Material}

El material necessari per a dur a terme aquesta pràctica consisteix en:

- Col·lecció d'insectes procedents de l'insectari del grup de Gestió Integrada de Plagues de la Universitat Jaume I o els que el mateix estudiantat ha agafat i ha portat al laboratori

- Lupa binocular

- Suros per clavar els insectes que es volen observar

- Clau taxonòmica per als ordres d'insectes

\subsection{Metodologia}

A partir del material de què disposem (col·leccions d'insectes punxats), els prendrem un per un per identificar-los.

Desclavarem els insectes de la planxa on es troben i, per observar-los a la lupa binocular, els clavarem sobre una peça de suro de $2 \times 2 \mathrm{~cm}$ aproximadament. Segons com clavem l'agulla al suro, podrem observar les estructures que ens interessen, tant de la cara superior com de la inferior o dels costats dels insectes. Sempre manipularem l'espècimen amb l'ajuda del suro, ja que altrament podem fer-lo malbé sense adonar-nos-en, en moure'l sota la lupa binocular. Cal tenir en compte que es tracta sempre d'insectes secs, molt fràgils, que se'ns trencaran si no els manipulem amb cura.

A continuació, i amb l'ajut de la lupa binocular i de la clau proporcionada, caldrà que determinem els ordres dels insectes proporcionats. 


\section{PRÀCTICA 2}

\section{Observació i identificació de les famílies de coleòpters d'importància agronòmica}

\section{Antecedents}

\subsection{Generalitats de l'ordre Coleoptera}

Els coleòpters, anomenats comunament escarabats, constitueixen l'ordre més extens dins del grup dels insectes; se n'han descrit més de 300.000 espècies. Pel que fa la mida, oscil·len des d'individus molt menuts $(0,25 \mathrm{~mm})$ fins a individus realment grans $(16 \mathrm{~cm})$, amb coloracions igualment variables. Els coleòpters es poden trobar en quasi tots els hàbitats llevat dels fons marins. Presenten com a característica comuna la modificació de l'ala anterior en èlitres coriacis que protegeixen les posteriors, membranoses, que són emprades en el vol. Aquestes es pleguen sota els èlitres durant el repòs, encara que de vegades són molt reduïdes, o fins i tot absents, i en general, amb la venació molt reduïda. L'aparell bucal és de tipus mastegador.

Els adults tenen el cap molt esclerotitzat, de tipus prògnat o hipògnat. En els curculiònids es prolonga en un rostre amb les peces bucals a l'extrem. Els ulls i les antenes presenten una morfologia altament variable. Les antenes juguen un paper molt important en la separació de famílies $i$ en la diferenciació de gèneres $i$ espècies. Poden ser filiformes (caràbids), moniliformes (tenebriònids), en maça (curculiònids), geniculades (histèrids), lamel-liformes (escarabèids), pectinades (lucànids), etc. (figura 16). Típicament són d'11 artells i sovint de menys. El pronòtum o corselet és gran i es distingeix clarament dorsalment. Per contra, el mesonòtum és menut i triangular (escudet). Les sutures pleurals tenen valor taxonòmic, igual que les potes, que poden ser marxadores, però també cavadores, nedadores o saltadores, $\mathrm{i}$ en general amb 5 artells al tars (tarsòmers). El nombre de tarsòmers és de gran importància $\mathrm{i}$ permet dividir els coleòpters mitjançant la fórmula tarsal (nombre de tarsòmers visibles en les tres potes), en pentàmers (5-5-5), tetràmers (4-4-4), trímers (3-3-3) o heteròmers (5-5-4) (figura 20) (Salgado et al., 2004).

El nombre de segments abdominals és complicat de determinar ja que no tots són visibles externament. Les genitàlies es troben dins l'abdomen, tancades, i són de gran valor taxonòmic.

Les larves posseeixen un cap molt desenvolupat; tenen les peces bucals mastegadores. Els ocels i les antenes poden estar presents o no. Acostumen a tenir tres parells de potes toràciques i ocasionalment cercs. Hi ha diversos tipus de larves, des de campodeïformes, eruciformes, escarabeïformes o àpodes (figura 1). 

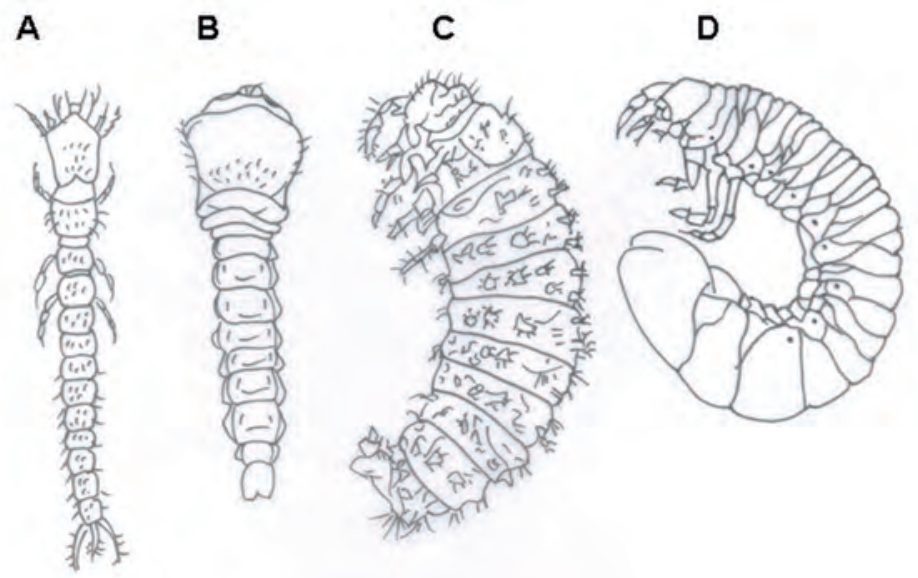

Figura 1. Tipus de larves de coleòpter. A) Campodeïforme; B) àpoda; C) eruciforme;

D) escarabeïforme. Adaptat de Salgado et al. (2004)

Les pupes són lliures o exarades, de coloració pàl-lida i recobertes d'una cutícula molt fina, encara que també poden ser semiobtectes i presentar una coberta (capoll).

La reproducció és, en general, de tipus sexual i el desenvolupament és holometàbol. La posta pot ser aïllada o en grups tant en terra com en diversos substrats vegetals. La durada del cicle de vida oscilla des de diverses generacions a l'any (espècies multivoltines) fins a una única generació a cavall de diversos anys.

Els coleòpters poden ser fitòfags quan les larves i els adults s'alimenten de qualsevol part vegetal, com per exemple l'escarabat de la creilla, Leptinotarsa decemlineata (Say) (Chrysomelidae), que pot consumir tota la fulla de la creilla; algunes espècies de Ceuthorrynchus (Curculionidae), que poden menjar tiges; Capnodis tenebroides (L.) (Buprestidae), que s'alimenta d'arrels i del coll de les plantes; espècies de la família Scolytidae, que poden danyar zones subcorticals de la planta; Anthonomus pomorum (L.) (Curculionidae), que s'alimenta dels botons florals de les pomeres; Balaninus nucum L. (Curculionidae), que es menja els fruit dels avellaners; alguns brúquids, que s'alimenten de llavors, etc. Però també trobem coleòpters fungívors (alguns estafilínids), sapròfags, depredadors, paràsits, copròfags i necròfags (Viñuela et al., 1992).

Tenen un interès particular aquelles espècies que poden servir per al control biològic d'espècies plaga com els coccinèl-lids, que s'alimenten principalment de pugons i cotxinilles; els caràbids i els estafilínids. També s'han descrit espècies que ajuden a controlar les males herbes com el crisomèlid Uroplata lantanae Buzzi i Winder, que pot regular les poblacions de Lantana camara L. a Austràlia. Tanmateix existeixen altres espècies que poden ser transmissores de virosis, com alguns crisomèlids i coccinèl-lids. 


\subsection{Classificació dels coleòpters}

En aquest manual seguirem la classificació establerta per Gillott (2005), el qual al seu torn segueix Crowson (1981). Per a simplificar-la, a la figura 2 es mostren les superfamílies considerades per aquest autor, però tan sols hi apareixen algunes de les famílies més importants per l'abundància numèrica o per la rellevància agroforestal.

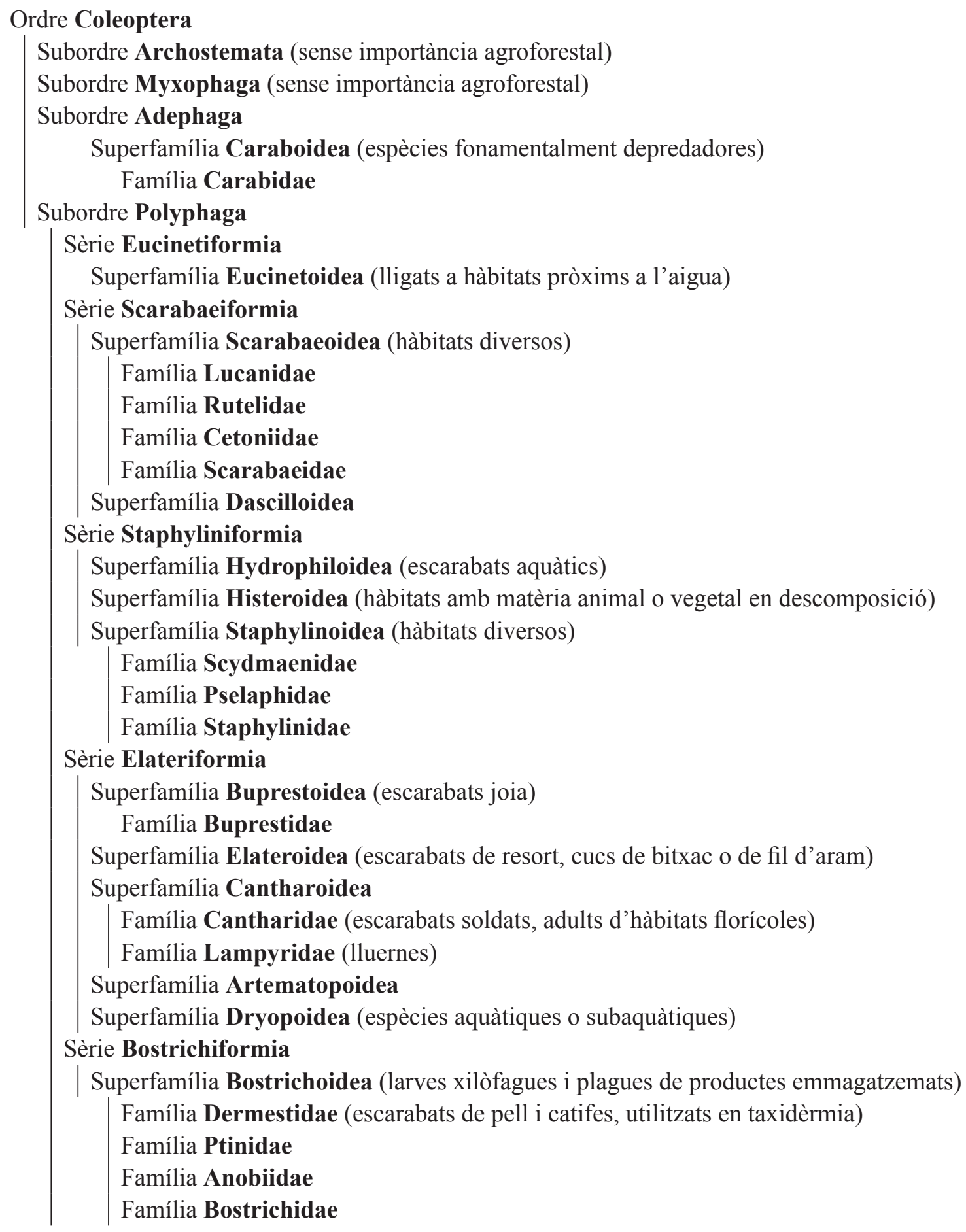




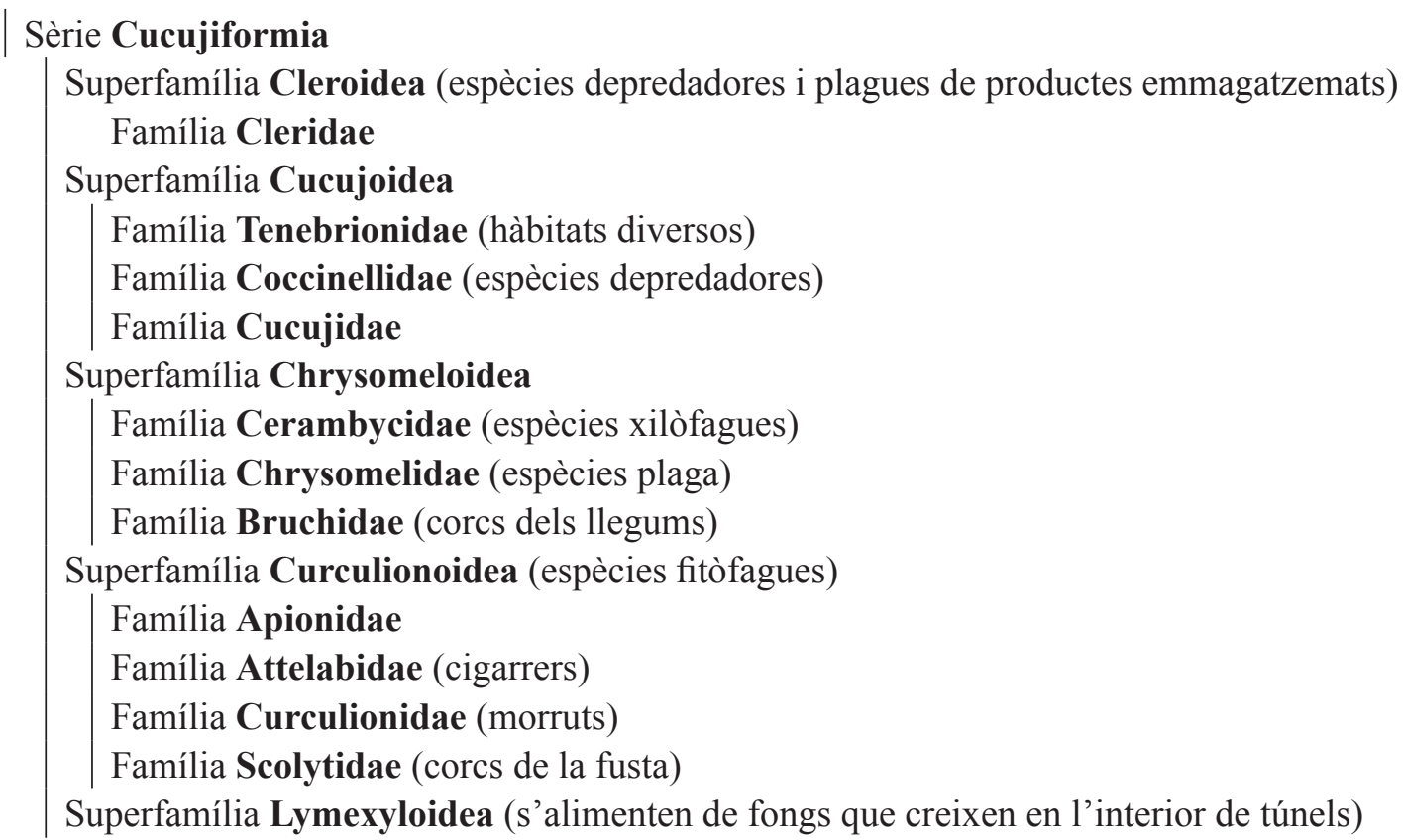

Figura 2. Classificació de l'ordre Coleoptera, on s'han destacat les famílies d'especial interès per l'abundància o importància agroforestal que tenen

\subsection{Característiques de les principals famílies $\mathrm{d}$ 'interès agronòmic}

\subsubsection{Subordre Adephaga}

El subordre Adephaga es caracteritza per la presència d'una cel·leta oblonga a les ales posteriors, la presència d'un sutura notopleural al protòrax i la fusió de les coxes de l'últim parell de potes amb el metastern per una articulació rígida, de manera que aquestes interrompen la zona mitjana del primer estern abdominal visible, que va seguit de 5 esterns abdominals visibles més (figures 14, 17 i 18) (Nieto Nafria i Mier Durante, 1985; Salgado et al., 2004). Les larves tenen potes amb 5 artells i 1 o 2 ungles.

Aquest subordre presenta al voltant de 9 famílies (segons autors), de les quals només la família Carabidae (Superfamilia Caraboidea) té importància agroforestal. La majoria d'espècies són depredadores, tant en estadi larvari (larves campodeïformes) com adult. Com a exemple tenim, dins la subfamília Carabinae, l'espècie Calosoma sycophanta (L.) depredadora de l'eruga peluda de l'alzina, Lymantria dispar (L.), i de la processionària dels pins, Thaumetopoea pityocampa (Denis i Schiffermuller) (Bachiller-Bachiller et al., 1981; Sánchez-Ruiz et al., 1997), o Pseudophonus rufipes De Geer i Harpalus distinguendus (Duftschmid), depredadors de pupes de la mosca de la fruita, Ceratitis capitata (Wiedemann) (Urbaneja et al., 2006), o alguns cicindèlids (subfamília Cicindelinae) com la Cicindela campestris L. de brillants 
colors i activa depredadora (Monzó et al., 2005) (figura 3). No obstant, en alguns casos, poden ser perjudicials per als cultius, com Zabrus tenebroides (Goeze) (cuc del sembrat), que ataca els cultius de blat i ordi, on s'alimenta tant de les fulles com de les espigues i el gra.

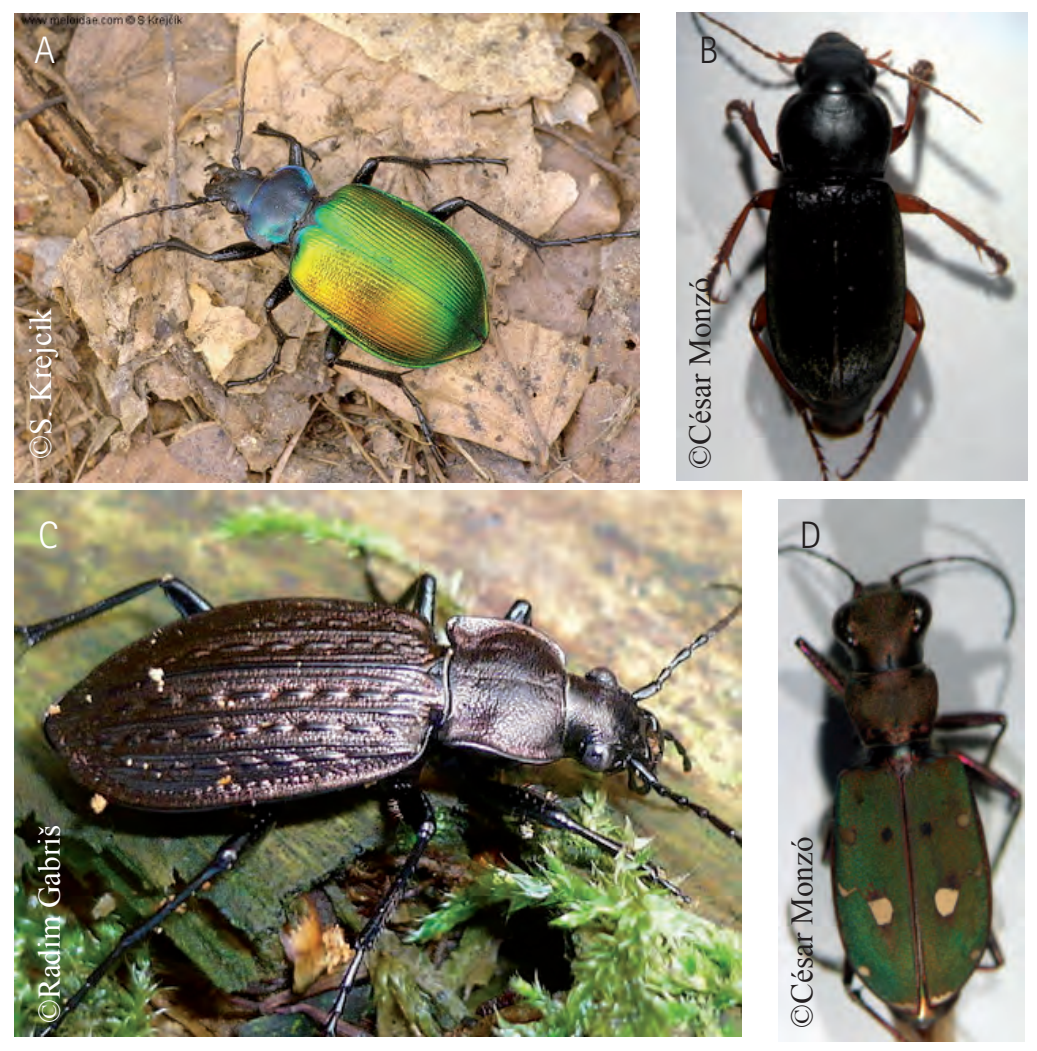

Figura 3. Exemples de caràbids depredadors. Adults de Calosoma sycophanta (A); Pseudophonus rufipes (B); Carabus granulatus L. (C); Cicindela campestris (D)

\subsubsection{Subordre Polyphaga}

El subordre Polyphaga no té la cel·leta oblonga en les ales posteriors; ni el solc notopleural; ni les coxes, unides al metastern per una articulació mòbil, divideixen el primer estern visible abdominal (figures 14, 17 i 18) (Salgado et al., 2004). Les potes de les larves dels polífags tenen quatre artells (sense comptar el tars) i una única ungla, vestigial o absent.

D'aquest subordre destaca la superfamília Staphylinoidea, la més gran entre els coleòpters. La família Staphylinidae és la que té un número major d'espècies darrere dels curculiònids. Els estafilínids de mida variable $(1-30 \mathrm{~mm})$. Es caracteritzen pels èlitres curts i truncats, que deixen la meitat de l'abdomen visible, les antenes moniliformes i les mandíbules grans en el cap prògnat. Són espècies sapròfagues o carnívores depredadores. Com a exemples tenim Anotylus inustus (Gravenhorst) i Atheta (Xenota) mucronata Kraatz, depredadors abundants als camps valencians de cítrics (Monzó et al., 2005) (figura 4). 

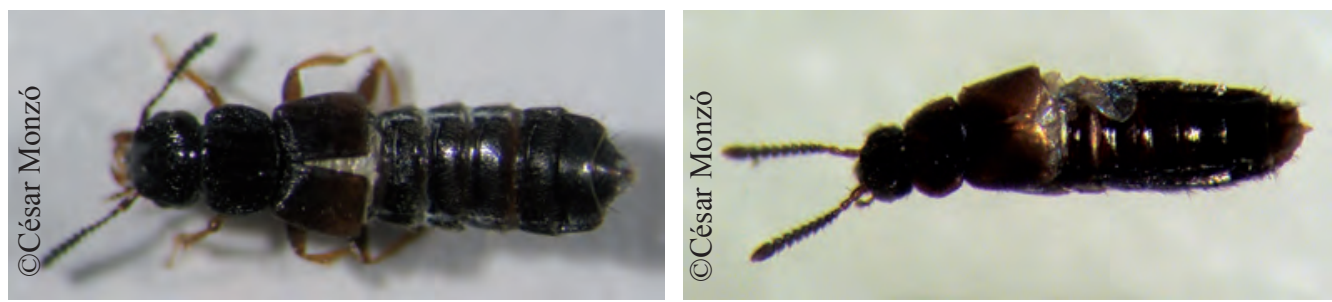

Figura 4. Adults dels estafilínids Anotylus inustus (esquerra) i d'Atheta (Xenota) mucronata (dreta)

Dins de la superfamília Scarabaeoidea trobem la família Lucanidae, amb larves xilòfagues i adults nectívors (Lucanus cervus L.), encara que els mascles presenten les mandíbules enormement desenvolupades (figura 5). A la família Scarabaeidae trobem larves d'algunes espècies que s'alimenten d'arrels, tubercles $i$ altres òrgans vegetals (cucs blancs), $i$ adults que tenen les típiques antenes amb l'extrem distal lamel-lat $i$ que s'alimenten de nèctar, fulles, flors, fruits o fins i tot de no res. Les larves de la subfamília Melolonthinae (p. ex. escarabats de Sant Joan) són radicívores i defoliadores, $\mathrm{i}$ tenen algunes espècies perjudicials per als cultius com Melolontha melolontha (L.), Rhizotrogus aestivus (Olivier) i Anoxia villosa (F.). Les larves de tipus escarabeïforme s'engloben dins del que es coneix com a cucs blancs, d'aspecte blanquinós i gruixut, arquejades i amb l'últim segment molt dilatat (Cabello García et al., 1997).
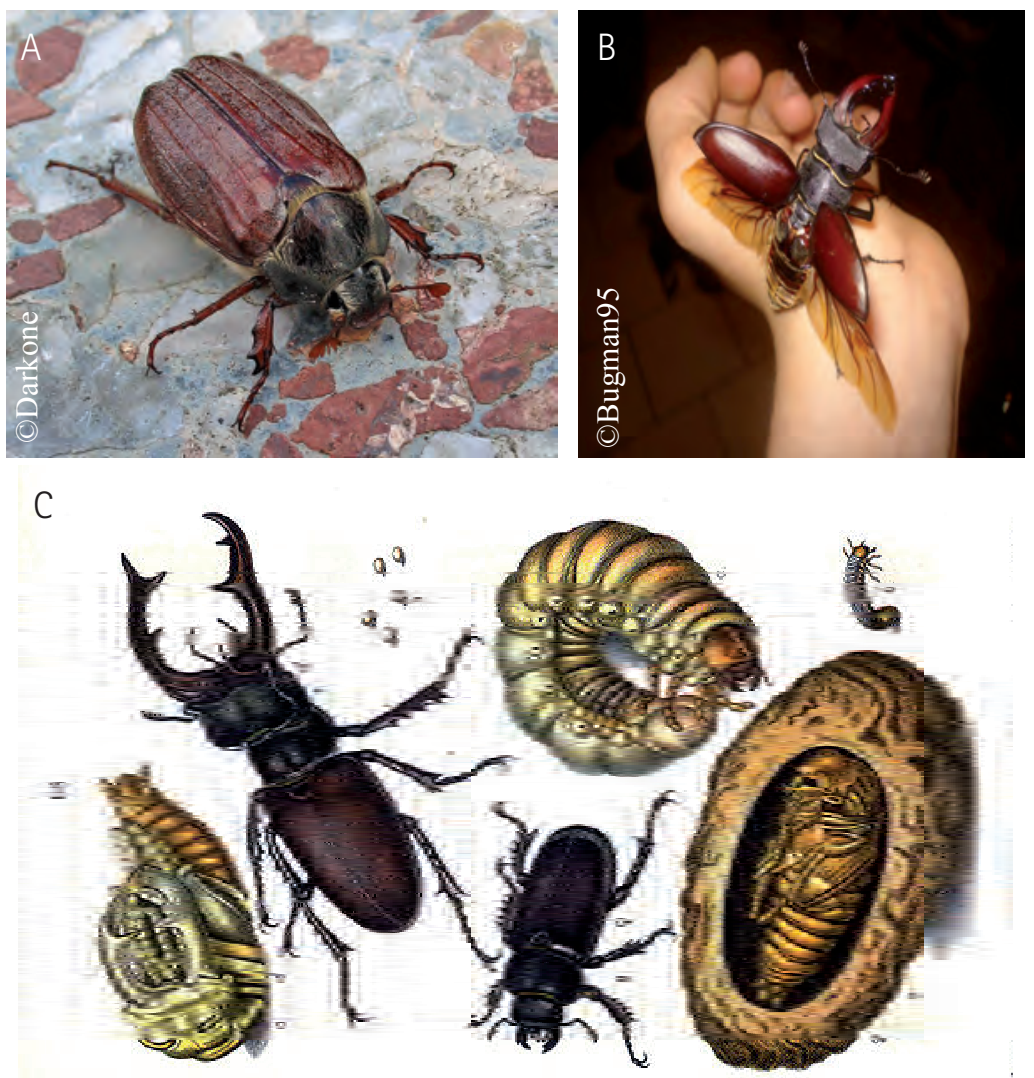

Figura 5. Adult de l'escarabeïd Melolontha melolontha (A); adult del cérvol volador Lucanus cervus amb les ales esteses, on es pot observar el primer parell d'ales coriaci (els èlitres)

i el segon parell membranós (B); i diversos estadis d'aquest coleòpter on es pot apreciar la larva escarabeïforme típica de la superfamília Scarabaeoidea (C) 
Dins de la sèrie Elateriformia trobem dos grups d'importància agronòmica, els Buprestidae (superfamília Buprestoidea) o escarabats joia pels seus colors metàllics, alguns d'importància agroforestal perquè són xilòfags de fusta viva o morta (Yela, 1997), i els elatèrids (superfamília Elateroidea) amb larves àpodes (conegudes com a cucs de bitxac o de fil d'aram), radicívores, de vegades perjudicials per als cultius, mentre que els adults són florícoles i fitòfags. Un exemple de buprèstid és Capnodis tenebrionis (L.) o cuc cabut, per la forma aplanada i dilatada del protòrax, que afecta tots els fruiters de pinyol i que fa galeries de secció ovalada (a diferència dels cerambícids, que les produeixen de secció redona) a la part baixa del tronc (Garrido Vivas, 1984) (figures 6A i B). L'elatèrid Agriotes lineatus (L.) és una espècie molt polífaga que danya creïlles, tomaques, pebreres, blat, panís, etc., però també fruiters i alzines (figures $6 \mathrm{C}$ i D). Els elatèrids també es coneixen com a escarabats saltadors per una estructura que tenen que els permet recobrar la posició quan cauen panxa enlaire.
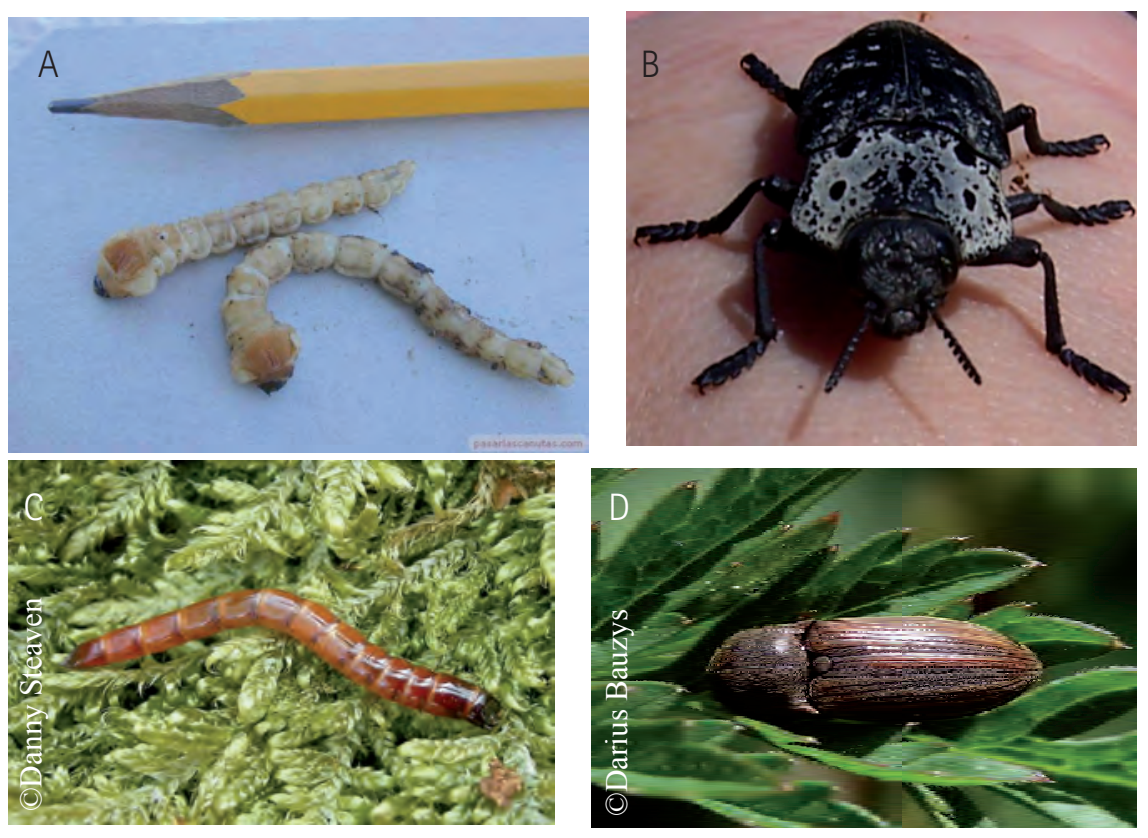

Figura 6. Larva (A) i adult (B) del buprèstid Capnodis tenebrionis; larva (C) i adult (D) de l'elatèrid Agriotes lineatus

Dins de la sèrie Bostrichiformia destaquen els dermèstids (superfamília Bostrichoidea), on els adults presenten un cos hemisfèric recobert d'escates i antenes claviformes i les larves viuen en pèls, plomes, cuiro, teixits i altres insectes morts (com els de les col·leccions entomològiques, on el gènere Anthrenus Schaeffer fa destrosses (figura 7A)), però també en gra emmagatzemat, com l'espècie Trogoderma granarium Everts (figura 7B), que causa danys d'una importància econòmica elevada. Els Ptinidae viuen de materials emmagatzemats (figura 7C) i els Anobiidae de fusta (Anobium punctatum (De Geer)) o productes emmagatzemats amb espècies importants com Lasioderma serricorne (F.) (figura 7D), Stegobium paniceum (L.) o Rhizopertha dominica (F.) (figura 7E), encara que aquesta última pertany a la família Bostrichidae (Yela, 1997). 

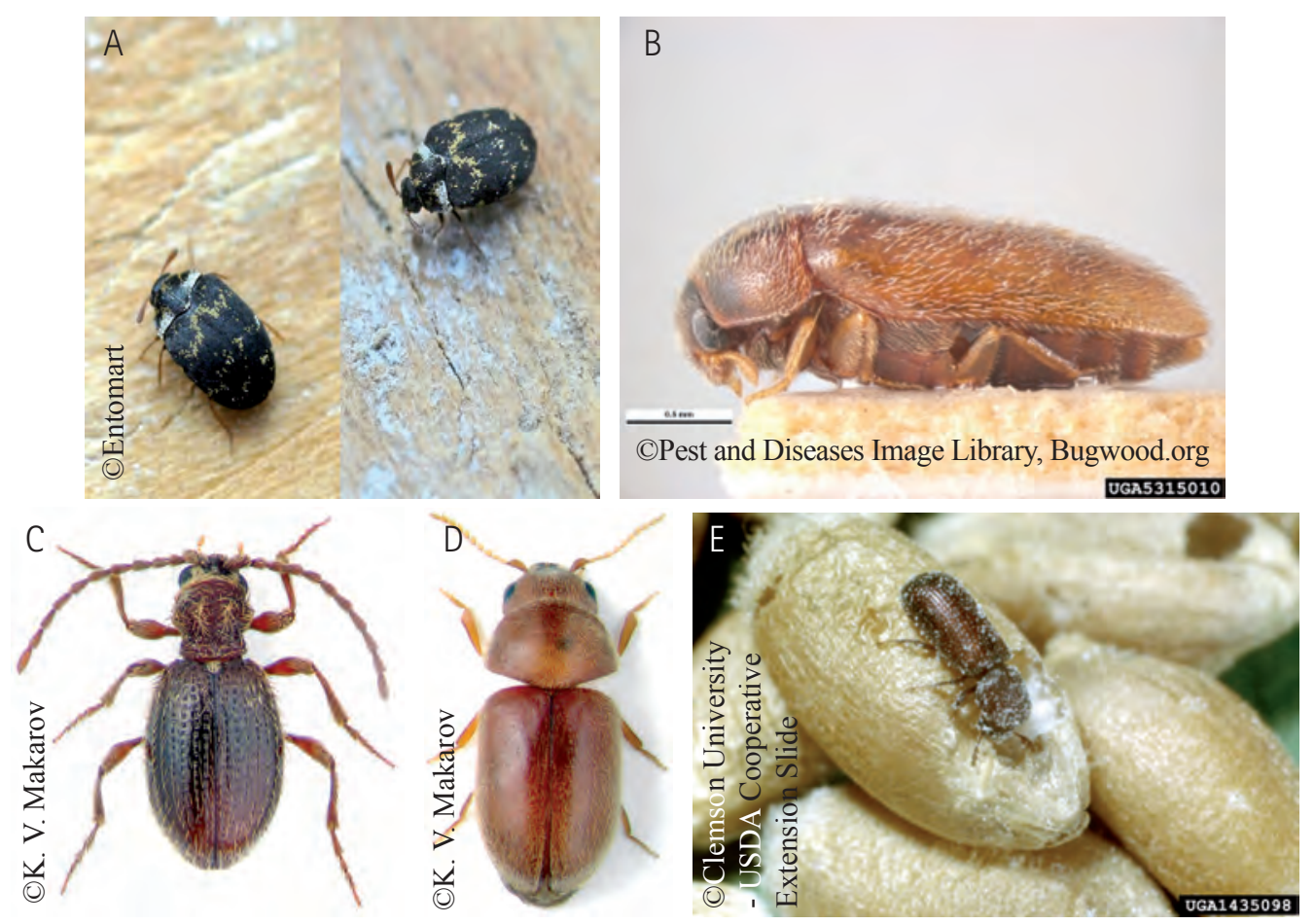

Figura 7. Adults dels dermèstids Anthrenus museorum (L.) (A) i Trogoderma granarium (B); adult del ptínid Ptinus villiger (Reitter) (C); adult de l'anòbid Lasioderma serricorne (D); i adult del bostríquid Rhyzopertha dominica (E)

La sèrie Cucujiformia és la més extensa en nombre d'espècies. Els adults de la família Cleridae (superfamília Cleroidea) s'alimenten de larves d'altres coleòpters, especialment d'escolítids, però també poden atacar productes emmagatzemats (figura 8).

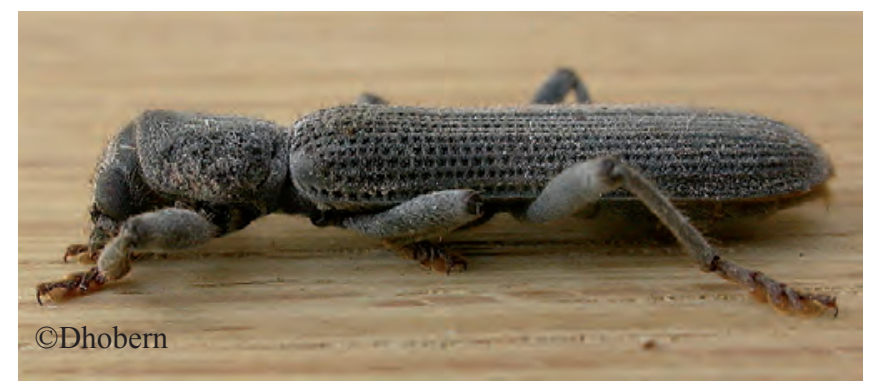

Figura 8. Adult del clèrid Eunatalis porcata (F.), espècie originària d'Austràlia

Els coleòpters tenebriònids (superfamília Cucujoidea) presenten una gran diversitat d'hàbitats, on destaca l'espècie Tenebrio molitor L. (cuc gran de la farina) o el gènere Tribolium Macleay (cuc menut de la farina) (figura 9A i B). Els Coccinellidae són les típiques marietes, depredadores tant en fase adulta com larvària (larves campodeïformes) d'hemípters, principalment pugons i cotxinilles, com la marieta de set punts, Coccinella septempunctata L., Rodolia cardinalis (Mulsant), espècie clau en el control de la cotxinilla acanalada Icerya purchasi Maskell, o Cryptolaemus montrouzieri Mulsant, depredadora del cotonet Planococcus citri (figures 10A-E). Moltes 
espècies d'aquesta família s'empren profusament en programes de control biològic, encara que també n'hi ha d'altres de perjudicials per als cultius pel fet de ser fitòfagues, com ara la pelosa dels melonars, Henosepilachna elaterii elaterii (= Epilachna chrysomelina) (Rossi), que ataca les cucurbitàcies (figura 10F). La família Cucujidae presenta espècies depredadores, però també d'altres que són plaga de productes emmagatzemats com el corcó dentat dels grans, Oryzaephilus surinamensis (L.), que es caracteritza per la vora serrada del pronòtum dels adults (Yela, 1997) (figura 9C).
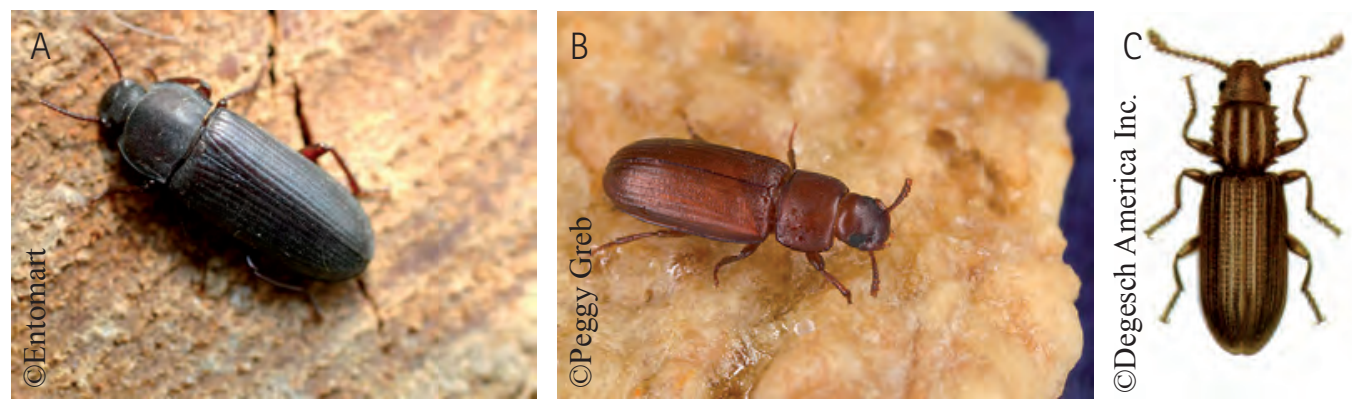

Figura 9. Adults del tenebriònids Tenebrio molitor (A) i Tribolium castaneum (Herbst) (B); i del cucújid Oryzaephilus surinamensis (C)
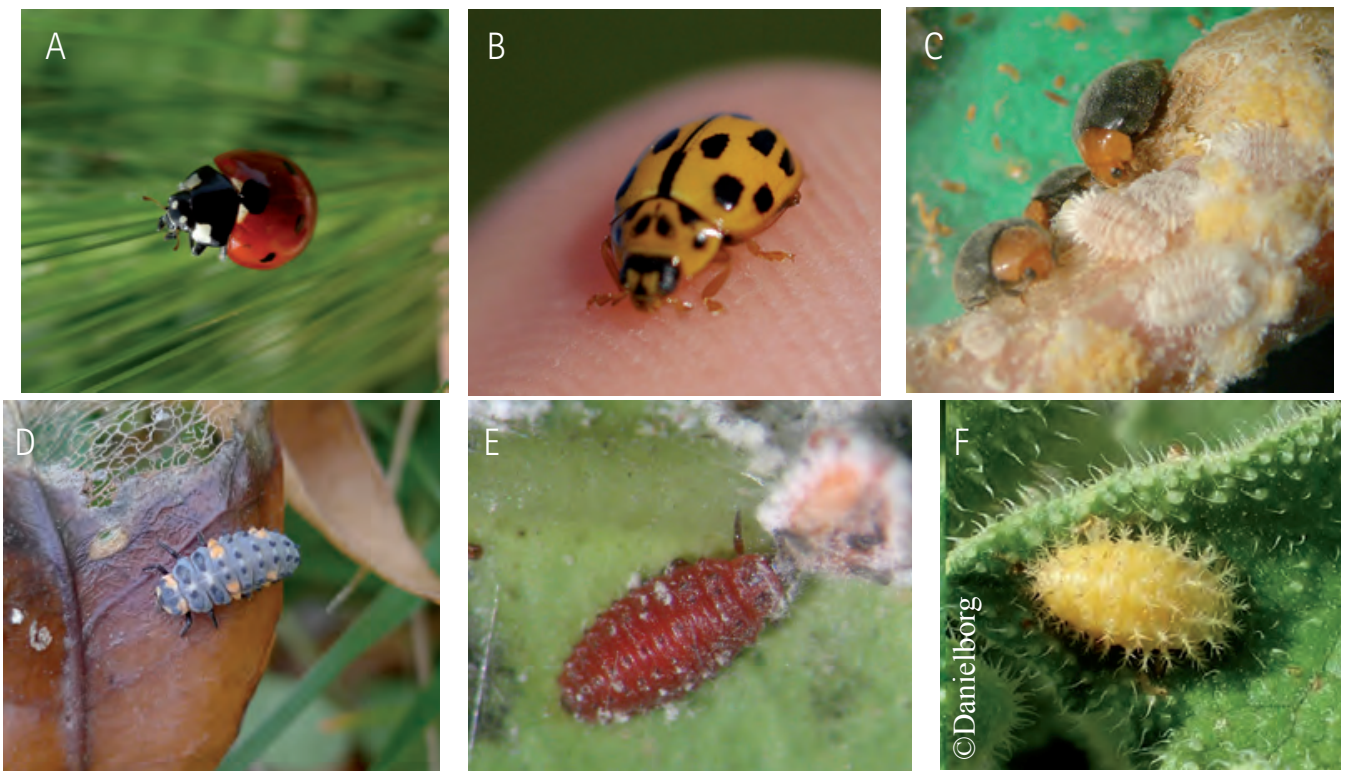

Figura 10. Adults dels coccinèl-lids Coccinella septempunctata (A); Propylea quatuordecimpunctata L. (B); i Cryptolaemus montrouzieri (C); larves dels coccinèl-lids C. septempunctata (D); Rodolia cardinalis (E); i Henosepilachna sp. (F)

Dins de la superfamília Chrysomeloidea trobem els cerambícids amb larves àpodes de color groguenc o blanquinós, xilòfagues o fitòfagues, on els adults tenen les antenes més llargues que el cos i són de colors brillants i dissenys característics. L'espècie Cerambyx cerdo L., un dels coleòpters més grans que tenim en la fauna ibèrica, danya els troncs de fruiters i alzinars (figura 11A). Els crisomèlids són fitòfags d'un gran nombre d'hostes, on destaquen plagues com l'escarabat de la creïlla, Leptinotarsa decemlineata (figura 11B), Colaspidema barbarum (F.) sobre 
l'alfals, o el cuc de les arrels del panís, Diabrotica virgifera Le Conte, crisomèlid que encara no es troba a Espanya però sí a Itàlia, i que ha causat greus destrosses en aquest cultiu als EUA (figura 11C). Els adults tenen coloracions vistoses i les larves presenten gran varietat de formes en funció del tipus de vida. En la família Bruchidae es troben larves devoradores de llavors de lleguminoses com els corcs Bruchus pisorum (L.) (figura 11D), que s'alimenta de pèsols frescs o Acanthoscelides obtectus Say, que menja tant pèsols i fesols frescs com d'emmagatzemats (figura 11E).
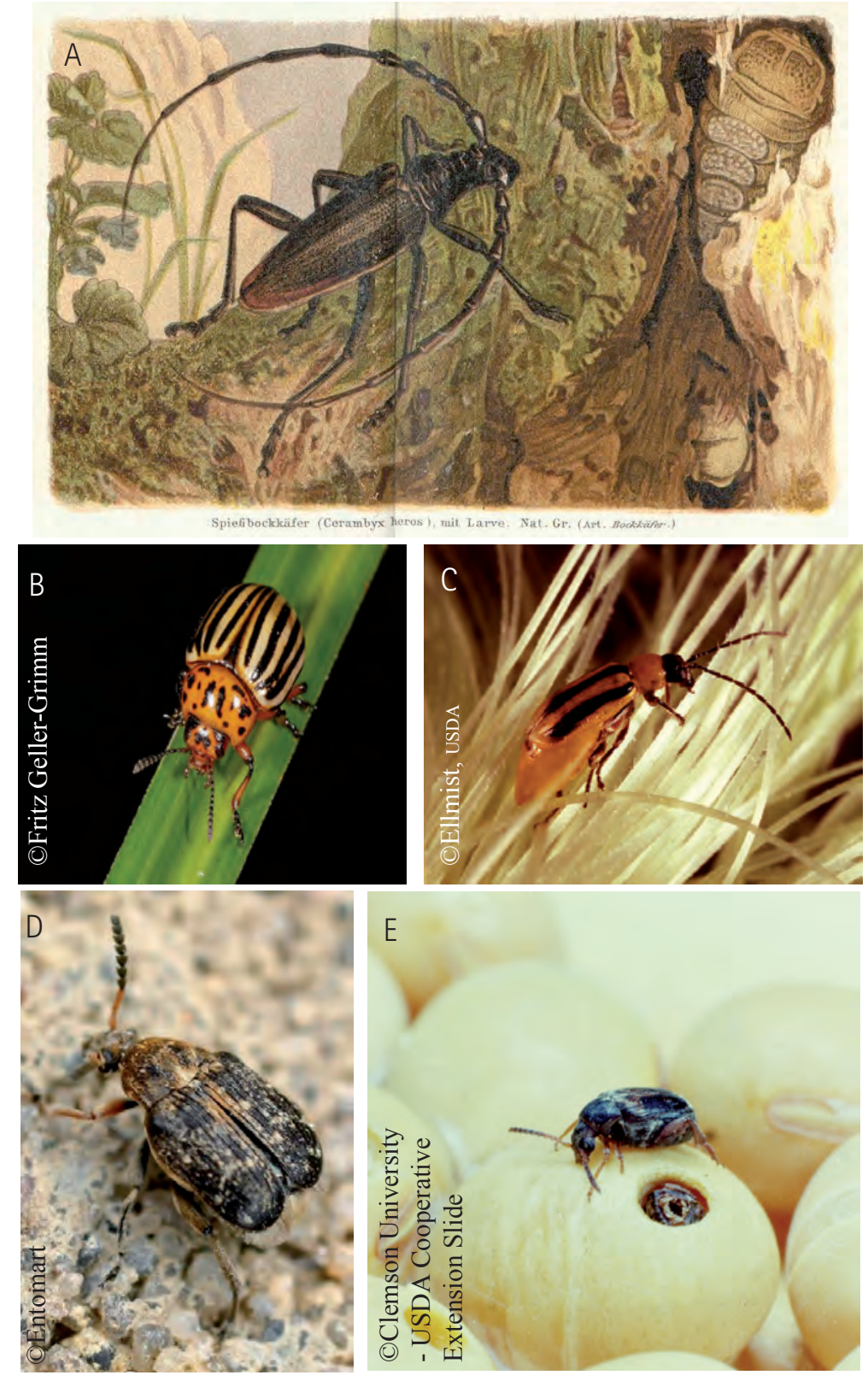

Figura 11. Dibuix de l'adult i la larva del cerambícid Cerambix cerdo (A); adults dels crisomèlids Leptinotarsa decemlineata (B) i Diabrotica virgifera (C); adults dels brúquids Bruchus pisorum (E) i Acanthoscelides obtectus (F)

La superfamília Curculionoidea és la més gran de tot el regne animal, amb més de 65.000 espècies descrites. Els curculiònids són típicament fitòfags de qualsevol òr- 
gan vegetal. Presenten antenes geniculades i claviformes, i rostre ben desenvolupat amb les peces bucals a l'extrem. Entre les espècies que cal destacar, a la família Curculionidae es troben el gènere Sitophilus Schoenherr, que s'alimenta de llavors de cereals, pèsols i fesols, i fa minvar seriosament les produccions de gra (figura 12A); el gènere Anthonomus Germar, que pot atacar cotó o pomera (figures 12B i C); o el morrut roig de les palmeres, Rhyncophorus ferrugineus (Olivier), curculiònid de gran mida que afecta seriosament les palmeres (figures 12D i E). La subfamília Scolytinae (o família Scolytidae segons els autors) és coneguda perquè els escarabats viuen en galeries que ells mateixos construeixen en la fusta i que acaben amb la vida dels arbres, com Pissodes notatus F. (figura 13A), que és una plaga greu dels pins, o transmetent malalties, com la grafiosi dels oms. La família Attelabidae i la família Apionidae també contenen espècies plaga de fruiters i lleguminoses com el cigarrer Byctiscus betulae (L) (el nom comú prové del fet que les femelles enrotllen la fulla de les vinyes en forma de cigar i fan la posta) (figura 13B) o Rhopalapion longirostre (Olivier) (figura 13C), que afecta malvàcies, respectivament.
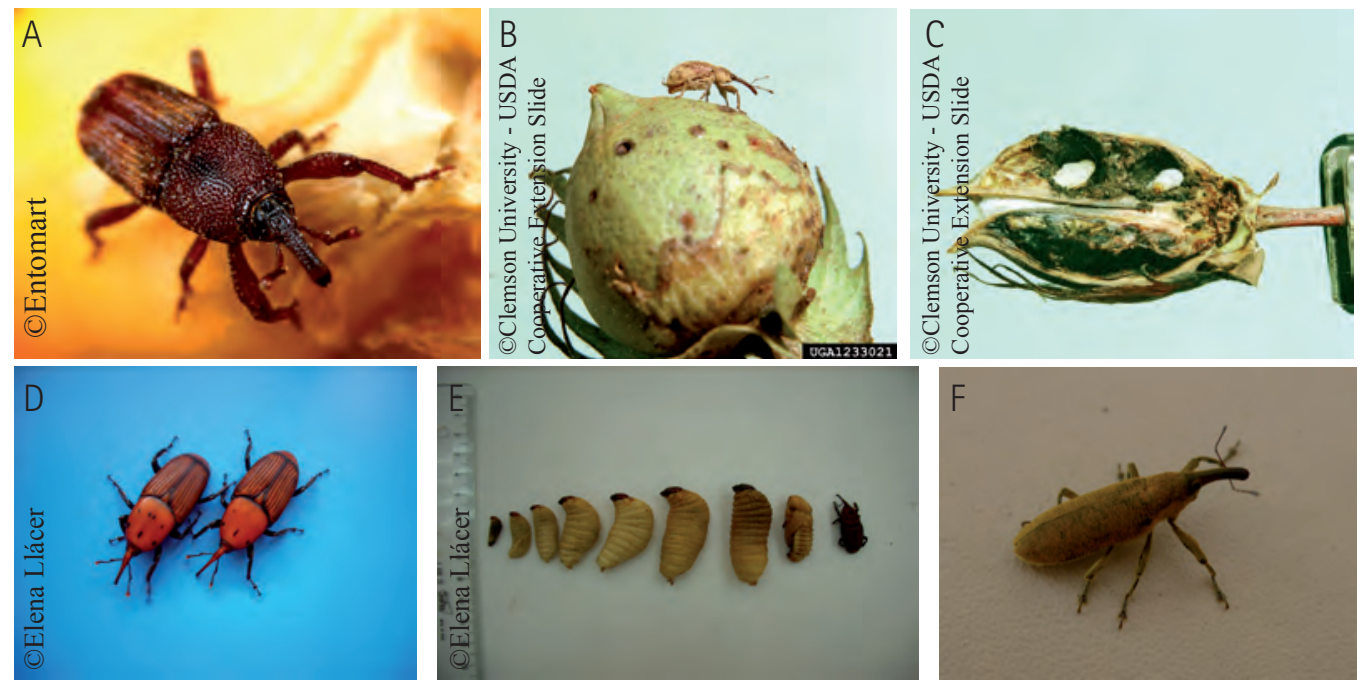

Figura 12. Exemples de curculiònids. Adult del gènere Sitophilus (A); adult (B) i larves (C) del morrut del cotó Anthonomus grandis Boheman; adults (D) i diferents estadis (E) del morrut roig de les palmeres Rhyncophorus ferrugineus; adult del diabló de les malves Lyxus algirus L. (F)
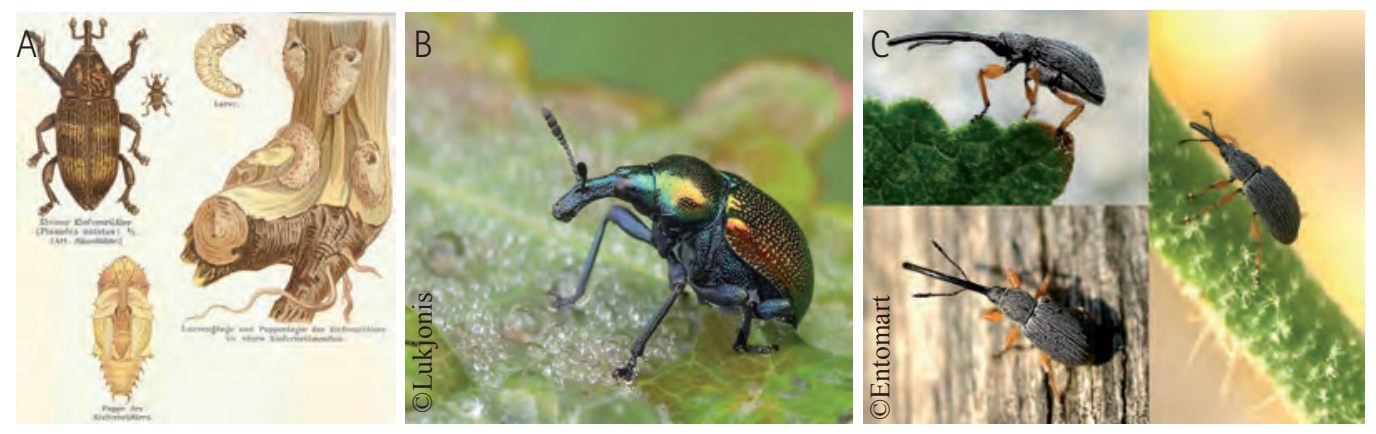

Figura 13. Diferents estadis de desenvolupament de l'escolítid Pissodes notatus (A); adult de l'attelàbid Byctiscus betulae (B); i adult de l'apiònid Rhopalapion longirostre (C) 


\subsection{Breus nocions morfològiques dels coleòpters}

A continuació es representen esquemàticament aquells caràcters morfològics d'utilitat a l'hora d'entendre les claus emprades en aquest manual (figures 14-19).

A

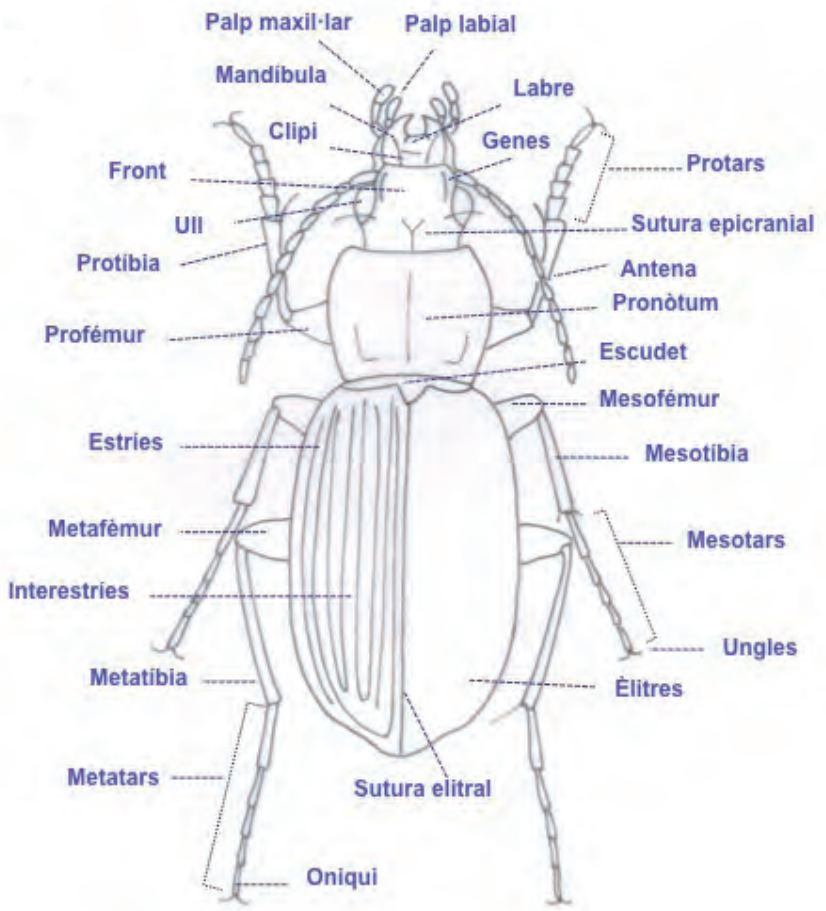

B

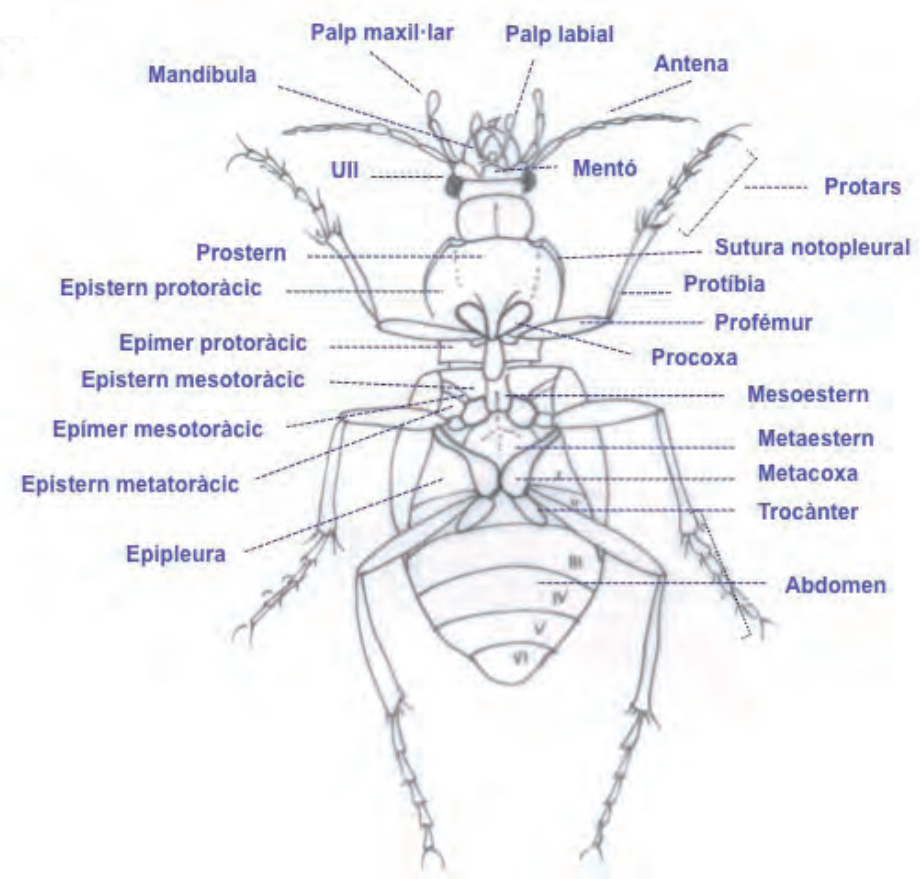

Figura 14. Vista dorsal (A) i ventral (B) d'un coleòpter Adephaga. Adaptat de Salgado et al. (2004) 


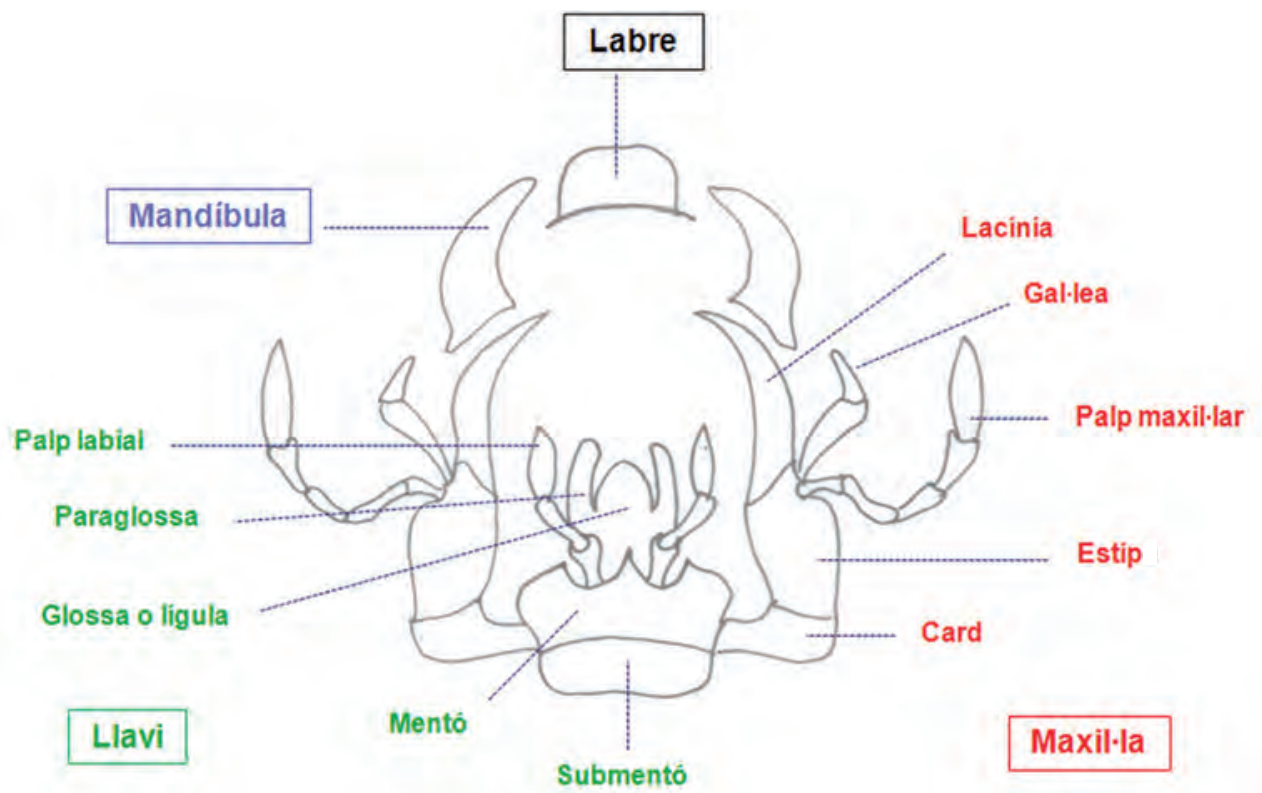

Figura 15. Aparell bucal d'un coleòpter Adephaga. Adaptat de Salgado et al. (2004)

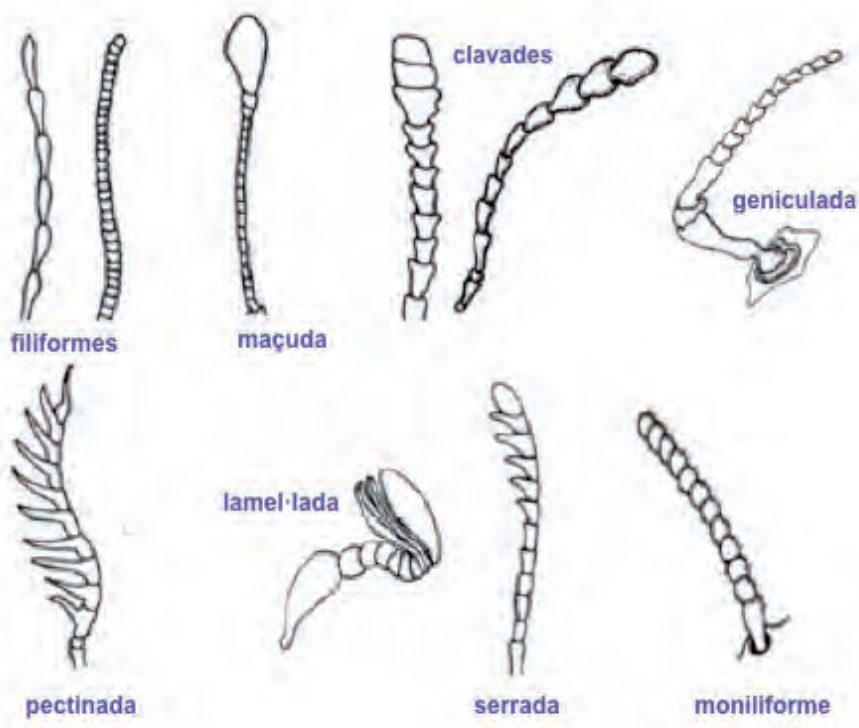

Figura 16. Tipus d'antenes dels coleòpters 


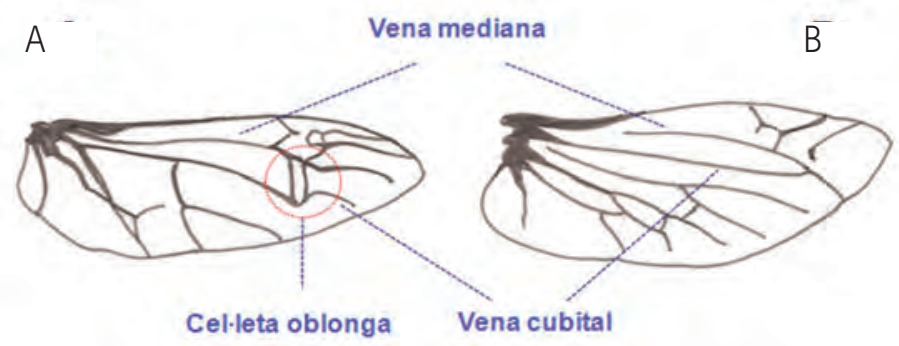

Figura 17. Estructura de les ales en un coleòpter de tipus adèfag (A) i de tipus polífag (B); hi destaca la presència de la cel·leta oblonga en l'adèfag. Adaptat de Blas et al. (1987)
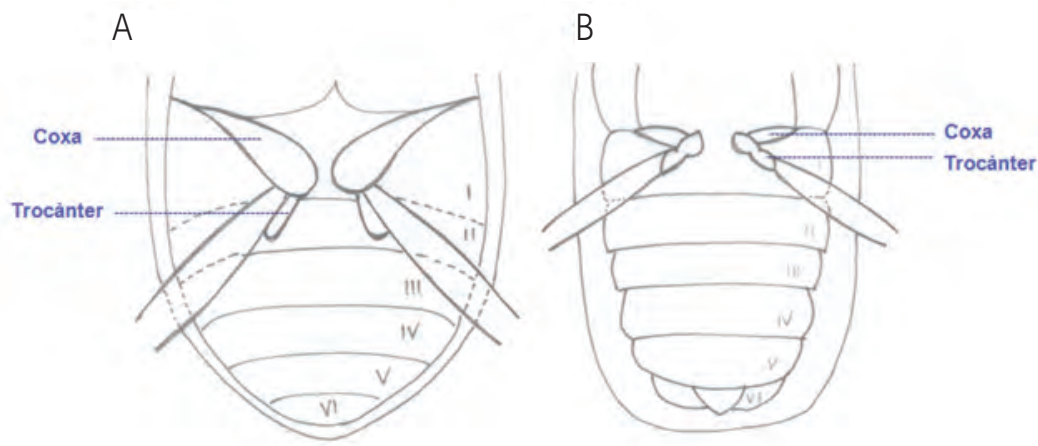

Figura 18. Abdomen de tipus adèfag (A) i de tipus polífag (B). Adaptat de Salgado et al. (2004)

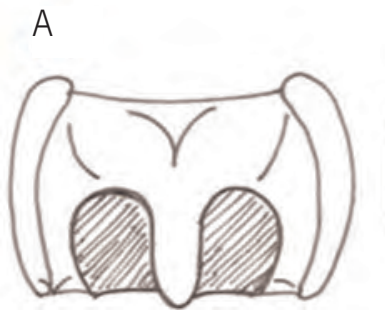

\section{B}

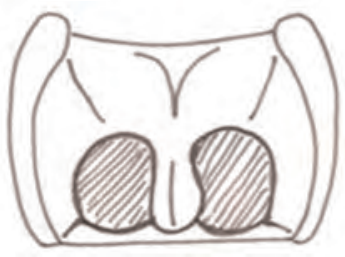

Figura 19. Cavitats coxals anteriors obertes (A) i tancades (B). Adaptat de Salgado et al. (2004)
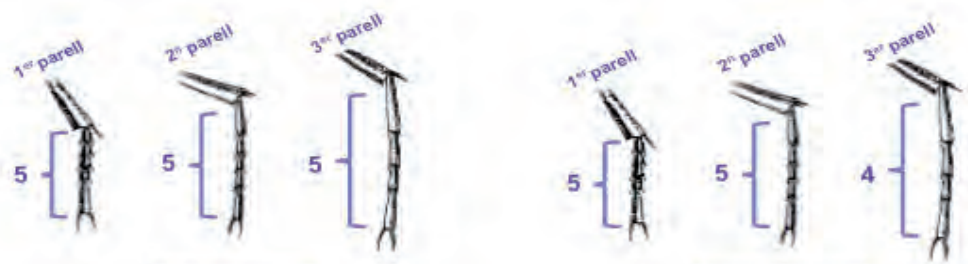

Pentàmers

Heterómers
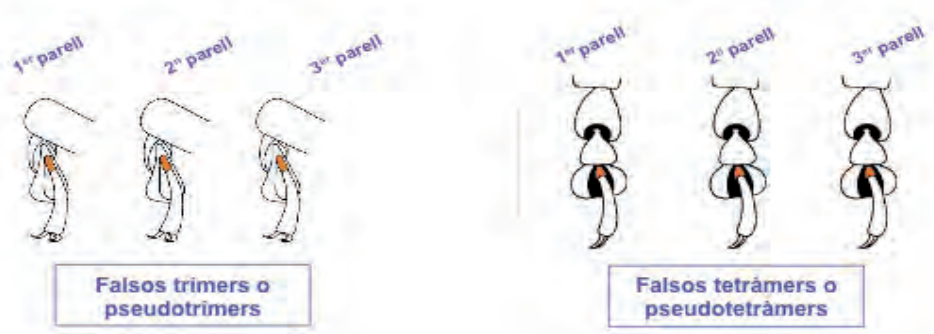

Figura 20. Exemple de fórmules tarsals 


\subsection{Clau simplificada de les principals superfamílies de coleòpters d'interès agronòmic}

La clau que proposem a continuació és una clau simplificada, modificada de Salgado et al. (2004), de les principals superfamílies de coleòpters d'interès agroforestal.

\begin{tabular}{|c|c|c|}
\hline 1. & $\begin{array}{l}3 \text { primers esterns abdominals no fusionats en conjunt i de } \\
5 \text { a } 8 \text { esterns visibles. Coxes posteriors no fixades al me- } \\
\text { tastern, i per tant ni divideixen el primer estern abdomi- } \\
\text { nal, ni la vora posterior de la coxa el sobrepassa. Sutures } \\
\text { pleurals no visibles. Nombre de tarsòmers variable (figura } \\
18 \mathrm{~B} \text { ). } \\
3 \text { primers esterns abdominals fusionats al mig i a continua- } \\
\text { ció } 5 \text { esterns visibles. Coxes de l'últim parell de potes fixes } \\
\text { al metastern per una articulació rígida. Sutures notopleurals } \\
\text { ben definides. Insectes pentàmers ( } 5 \text { tarsòmers en totes les } \\
\text { potes) (figura 18A). }\end{array}$ & $\begin{array}{l}\text { Subordre Polyphaga } \\
2\end{array}$ \\
\hline \multirow[t]{2}{*}{2.} & $\begin{array}{l}6 \text { o } 7 \text { esterns abdominals visibles, dels quals el primer sem- } \\
\text { pre està reduït i en forma de dues peces triangulars laterals } \\
\text { (vores no paral·leles). }\end{array}$ & 5 \\
\hline & $\begin{array}{l}\text { De } 5 \text { a } 8 \text { esterns abdominals visibles, el primer mai reduït a } \\
\text { peces laterals (vores paral:leles). }\end{array}$ & 7 \\
\hline 3. & $\begin{array}{l}\text { Antenes que tenen almenys els últims artells pubescents. } \\
\text { Insectes de terra amb potes marxadores i sense sedes. } \\
\text { Antenes glabres (sense pubescència). Insectes aquàtics, de } \\
\text { forma ovalada, amb les potes posteriors adaptades per a la } \\
\text { natació i amb llargues sedes. }\end{array}$ & $\begin{array}{l}\text { Superfamílies sense interès } \\
\text { agroforestal }\end{array}$ \\
\hline \multirow[t]{2}{*}{4.} & $\begin{array}{l}\text { Antenes filiformes (figura 16) (11 artells) o eixamplades ( } 2 \\
\text { artells). Peces bucals no recobertes per una prolongació del } \\
\text { mentó. }\end{array}$ & Superfamília Caraboidea \\
\hline & $\begin{array}{l}\text { Antenes moniliformes (figura 16) (11 artells). Peces bucals } \\
\text { recobertes per una prolongació del mentó. Pronòtum amb } \\
\text { tres solcs longitudinals. }\end{array}$ & $\begin{array}{l}\text { Superfamília Rhysodoidea } \\
\text { Rhysodes sulcatus (F.) } \\
\text { (única espècie ibèrica que viu } \\
\text { a l'interior de troncs d'avets } \\
\text { podrits) }\end{array}$ \\
\hline \multirow[t]{2}{*}{5.} & $\begin{array}{l}\text { Antenes amb formes diverses, claviformes, filiformes, ge- } \\
\text { niculades, però mai pectinades ni lamel·lades (figura 16). }\end{array}$ & 6 \\
\hline & $\begin{array}{l}\text { Antenes en maça, formades per làmines situades en un sol } \\
\text { costat dels artells, que poden ser fixes (pectinades) o mò- } \\
\text { bils (lamel-lades) (figura 16). }\end{array}$ & Superfamília Scarabaeoidea \\
\hline \multirow[t]{2}{*}{6.} & $\begin{array}{l}\text { Antenes geniculades. Si són de llargària similar o més } \\
\text { curtes que els palps maxillars, amb un artell modificat per } \\
\text { la còpula. Els últims cinc artells (del } 7 \text { a l'11) formen una } \\
\text { maça pubescent. Els } 5 \text { primers, (de vegades } 3 \text { o 4) simples } \\
\text { i sense pèls. Cap generalment amb la sutura epicranial en } \\
\text { forma de Y. }\end{array}$ & Superfamília Hydrophiloidea \\
\hline & $\begin{array}{l}\text { Antenes sempre més llargues que els palps maxil-lars i mai } \\
\text { diferenciades en dues regions per un artell copulador. Cap } \\
\text { sense sutura epicranial en forma de Y. }\end{array}$ & Superfamília Staphylinoidea \\
\hline
\end{tabular}




\begin{tabular}{|c|c|c|}
\hline 7. & $\begin{array}{l}\text { Coxes posteriors, quasi sempre, amb una excavació més o } \\
\text { menys marcada en la cara posterior, on s'allotja el fèmur } \\
\text { retret. Cavitats coxals anteriors obertes internament i exter- } \\
\text { na (figura 19A). Antenes filiformes, serrades, pectinades o } \\
\text { engrossides, rara vegada amb maça veritable. Espiracles del } \\
\text { vuitè segment abdominal diferenciats. Novè segment abdo- } \\
\text { minal del mascle amb les pleures confluents en la línia mitja- } \\
\text { na. Tarsos quasi sempre pentàmers (5-5-5), mai heteròmers. } \\
\text { Coxes posteriors rara vegada amb excavació posterior } \\
\text { per acollir al fèmur. Si es veuen, les antenes són en maça } \\
\text { (figura 16). Cavitats coxals anteriors totalment o parcial- } \\
\text { ment tancades externament o interna (figura 19B). Antenes } \\
\text { filiformes o en maça, rara vegada serrades o pectinades. Es- } \\
\text { piracles del vuitè segment abdominal vestigials o absents. } \\
\text { Novè segment abdominal del mascle, generalment amb les } \\
\text { pleures separades per una sutura en la línia mitjana o no } \\
\text { unides. }\end{array}$ & 11 \\
\hline 8. & $\begin{array}{l}\text { Coxes anteriors lleugerament voluminoses. Cap sense ex- } \\
\text { cavacions darrere la inserció de les maxil·les i labre lliure. } \\
\text { Abdomen generalment amb } 5 \text { esterns visibles. Cel·la radial } \\
\text { de les ales menuda. } \\
\text { Coxes anteriors molt voluminoses, sobreeixides, cap } \\
\text { generalment amb excavacions darrere de la inserció de les } \\
\text { maxil·les i el labre no diferenciat. Abdomen amb més de } 5 \\
\text { esterns visibles. Cel·la radial de les ales prou llarga. }\end{array}$ & $\begin{array}{l}\text { Superfamílies sense interès } \\
\text { agroforestal }\end{array}$ \\
\hline 9. & $\begin{array}{l}\text { Antenes generalment serrades. Coxes anteriors en general } \\
\text { còniques i poc voluminoses. } \\
\text { Antenes en forma de maça terminal o filiforme, curtes i } \\
\text { amples, rara vegada serrades o pectinades. Coxes anteriors } \\
\text { transverses i més o menys eixides. }\end{array}$ & $\begin{array}{l}10 \\
\text { Superfamília sense interès } \\
\text { agroforestal }\end{array}$ \\
\hline 10. & $\begin{array}{l}\text { Metastern sense sutura transversa. Els } 2 \text { primers esterns } \\
\text { abdominals tan separats com el segon i el tercer. Protòrax } \\
\text { més o menys mòbil respecte al mesotòrax i acabat en unes } \\
\text { puntes prou agudes. Tarsos rarament amb més d'un artell } \\
\text { proveït de lòbuls adhesius. Antenes llargues i separades. } \\
\text { Metastern amb la sutura transversa molt ben marcada. Els } \\
2 \text { primers esterns abdominals molt fusionats, sense sutures } \\
\text { aparents o quasi obliterades. Protòrax immòbil respecte al } \\
\text { mesotòrax i de contorn arredonit. Tarsos amb lòbuls adhe- } \\
\text { sius des del segon fins al quart tarsòmer. Antenes curtes i } \\
\text { en general serrades. }\end{array}$ & Superfamília Buprestoidea \\
\hline 11. & $\begin{array}{l}\text { Coxes anteriors generalment voluminoses i sovint amb una } \\
\text { placa femoral més o menys diferenciada. Tarsos pentàmers } \\
\text { (5-5-5), el primer de vegades molt menut. Antenes quasi } \\
\text { sempre amb els } 3 \text { últims artells diferenciats dels restants. } \\
\text { Cinc esterns abdominals visibles. } \\
\text { Coxes anteriors no voluminoses i si ho són els tarsos són } \\
\text { heteròmers (5-5-4) o pseudotetràmers (falsos tetràmers). } \\
\text { Coxes posteriors sense placa femoral. Sense ocels. }\end{array}$ & Superfamília Bostrichoidea \\
\hline
\end{tabular}




\begin{tabular}{|c|c|c|}
\hline 12. & $\begin{array}{l}\text { Tarsos pseudotetràmers de } 5 \text { artells amb el quart molt me- } \\
\text { nut (falsos tetràmers), tapat pels lòbuls del tercer; mai hete- } \\
\text { ròmers. Del primer al tercer artell amb lòbuls adhesius per } \\
\text { la cara ventral. Edeagus sense paràmers articulats. Sutura } \\
\text { transversa del metastern generalment diferenciada. Cap en } \\
\text { molts casos amb un rostre més o menys marcat. } \\
\text { Tarsos de diversos models. Quan són pseudotetràmers, } \\
\text { l'edeagus presenta els paràmers articulats o les antenes } \\
\text { amb els tres últims artells en maça. Si el cap presenta ros- } \\
\text { tre, els tarsos són heteròmers al menys en el mascle. Sutura } \\
\text { transversa del metastern no diferenciada. }\end{array}$ & 13 \\
\hline 13. & $\begin{array}{l}\text { Cap sense rostre, o si existeix, se situa per davant dels ulls } \\
\text { i la sutura gular està diferenciada i separada. Cap sense } \\
\text { solcs longitudinals per la base de les antenes (escap). Els } 3 \\
\text { últims artells de les antenes mai presenten forma de maça } \\
\text { diferenciada. } \\
\text { Cap amb una trompa més o menys diferenciada i amb la } \\
\text { sutura gular generalment confluent. Antenes generalment } \\
\text { geniculades i en maça. Cap amb solcs en els quals s'allotja } \\
\text { la base de les antenes en repòs. }\end{array}$ & Superfamília Curculionoidea \\
\hline 14. & $\begin{array}{l}\text { Tarsos sempre pentàmers. Coxes anteriors voluminoses o } \\
\text { transverses. Tarsos amb empodi conspicu i amb } 2 \text { sedes } \\
\text { (bisetòs) entre les ungles. Abdomen amb } 5 \text { o } 6 \text { esterns } \\
\text { visibles. } \\
\text { Tarsos amb una altra composició o si són pentàmers, les } \\
\text { coxes anteriors són arredonides o transverses. Empodi dels } \\
\text { tarsos menut o absent. }\end{array}$ & Superfamília Cleroidea \\
\hline 15. & $\begin{array}{l}\text { Tarsos pentàmers filiformes. Totes les coxes més o menys } \\
\text { voluminoses. Antenes curtes més o menys serrades. Abdo- } \\
\text { men amb } 6 \text { o } 7 \text { esterns visibles. } \\
\text { Coxes gens voluminoses o si ho són, els tarsos són hete- } \\
\text { ròmers (5-5-4). Antenes filiformes o en maça, rarament } \\
\text { serrades. Abdomen en general amb } 5 \text { esterns visibles, i si } \\
\text { se'n veuen } 6 \text { o } 7 \text {, els tarsos acostumen a ser heteròmers. }\end{array}$ & $\begin{array}{l}\text { Superfamília sense interès } \\
\text { agroforestal } \\
16\end{array}$ \\
\hline 16. & $\begin{array}{l}\text { Tarsos heteròmers en ambdós sexes (5-5-4) o tetràmers } \\
\text { (3-4-4) o (4-4-4), en els mascles. Rarament trímers (3-3-3). } \\
\text { Coxes anteriors generalment voluminoses o si no, els tro- } \\
\text { cànters són de tipus heteròmer. } \\
\text { Tarsos mai heteròmers. Coxes anteriors no voluminoses. } \\
\text { Si els trocànters són de tipus heteròmer, els tarsos són pen- } \\
\text { tàmers o pseudotrímers (tercer artell molt menut i amagat } \\
\text { en el segon) o trímers. Antenes generalment en maça. }\end{array}$ & $\begin{array}{l}\text { Superfamília Cucujoidea, } \\
\text { secció Clavicornia }\end{array}$ \\
\hline
\end{tabular}




\subsection{Clau simplificada de les principals famílies de coleòpters d'interès agronòmic}

A continuació presentem els trets morfològics principals d'algunes de les famílies i subfamílies més importants, incloent, en alguns casos, la clau molt simplificada (modificada de Salgado et al., 2004) per arribar-hi.

\section{Superfamília Caraboidea}

\begin{tabular}{|c|c|c|}
\hline \multicolumn{2}{|r|}{$\begin{array}{l}\text { Antenes d'onze artells filiformes o setiformes. Els dos esperons de } \\
\text { les tíbies anteriors desiguals o inserits a diferent altura (figura 3). }\end{array}$} & Família Carabidae \\
\hline $\mathrm{a}$ & $\begin{array}{l}\text { Labre molt més llarg que el clipi i dilatat cap als costats. Cap } \\
\text { gruixut, sempre hipògnat. Antenes inserides en els costats del } \\
\text { front. Ulls molt prominents. Èlitres mai estriats i amb taques } \\
\text { blanques de formes diverses. Insectes freqüents de llocs sole- } \\
\text { jats i arenosos (figura 3D). }\end{array}$ & Subfamília Cicindelinae \\
\hline b & $\begin{array}{l}\text { Labre més curt o igual que el clipi i no dilatat cap als costats. } \\
\text { Cap normalment prògnat. Antenes inserides sota els costats } \\
\text { laterals del front, pròximes a la base de les mandíbules. Èli- } \\
\text { tres amb estries presents (figures } 3 \mathrm{~A}, \mathrm{~B} \text { i C). }\end{array}$ & Subfamília Carabinae \\
\hline
\end{tabular}

\section{Superfamília Scarabaeoidea}

a $\quad$ Làmines de la maça antenal no apilades les unes contra les altres, adoptant la típica forma pectinada. Mandíbules més o menys allargades i voluminoses. Formes allargades i paralleles (figures $5 \mathrm{~B}$ i C).

b Làmines de la maça antenal estretament unides les unes a les altres com els fulls d'un llibre (lamel·lades) i amb tres artells finament tomentosos. Antenes de 8 a 9 artells. Estigmes abdominals oberts a les pleures. Penúltim tèrgum poc quitinitzat i no soldat al corresponent estern. Clipi ben desenvolupat que deixa lleugerament al descobert la punta de les mandíbules, les quals són curtes. Tíbies posteriors amb 1 o 2 espines terminals. Cos arredonit o semicircular (figura 5A).

\section{Superfamília Staphylinoidea}

a Coxes posteriors sense placa femoral o només desenvolupada en el costat intern. Antenes quasi sempre d'11 artells, filiformes o amb una maça d'1 a 3 artells. Abdomen amb dos terga basals membranosos com a màxim i des del tercer coriaci (figura 4).

Família Scarabaeidae

Família Lucanidae

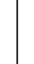




\section{Superfamília Elateroidea}

a Coxes posteriors transverses, quasi sempre amb plaques femorals aparents. Generalment només són visibles 5 esterns abdominals que no acostumen a estar soldats. Esterns abdominals units per unes membranes, i el quart vorejat per una membrana groguenca brillant. Protòrax amb els dos costats tallants i d'angles aguts. Procés intercostal del prostern mòbil Família Elateridae però inserit en una cavitat del mesostern. Aquest procés està corbat en l'àpex. Labre visible externament. Insercions antenals molt pròximes als ulls i ben separades entre si. Els artells antenals mai formen maça (figures 6C i D).

\section{Superfamília Buprestoidea}

a Pronòtum oblic amb els costats laterals senzills o en qui1la. Part superior dels cos molt esculpida, especialment els èlitres. Metastern amb la sutura transversa molt ben marcada. Els 2 primers esterns abdominals molt fusionats, sense sutures aparents o quasi obliterades. Protòrax immòbil respecte al mesotòrax i de contorn arredonit. Tarsos amb 5 artells Família Buprestidae amb lòbuls adhesius des del segon al quart tarsòmer. Antenes curtes $\mathrm{i}$ en general serrades, alguna vegada en maça (figures $6 \mathrm{~A} \mathrm{i} \mathrm{B).}$

\section{Superfamilia Bostrichoidea}

\begin{tabular}{|l|l|l|}
\hline 1 & $\begin{array}{l}\text { Coxes anteriors molt voluminoses i contigües. Tarsos mai amb } \\
\text { el primer artell menut. Trocànters articulats amb el fèmur obli- } \\
\text { quament. Sovint amb 1 o 2 ocels dorsals. Antenes filiformes, } \\
\text { rara vegada serrades, amb els } 3 \text { últims artells poc engrossits. El } \\
\text { protòrax no té mai forma de caputxa (figures 7A i B). } \\
\text { Coxes anteriors còniques o transverses, però poc voluminoses. } \\
\text { Tarsos amb el primer artell menut. Trocànters articulats amb el } \\
\text { fémur, generalment de manera transversa. Sence ocels. Ante- } \\
\text { nes filiformes i serrades, amb els 3 últims artells engrossits. } \\
\text { El protòrax te forma de caputxa, cobrint el cap dorsalment. }\end{array}$ & 2 \\
\hline 2 & $\begin{array}{l}\text { Antenes inserides als costats del cap, dentades o pectinades, } \\
\text { amb els últims artells eixamplats. } \\
\text { Antenes inserides damunt del front, entre els ulls, i sempre } \\
\text { molt properes entre si, filiformes i amb tots els artells molt } \\
\text { similars (figura 7C). }\end{array}$ & Família Ptinidae \\
\hline 3 & $\begin{array}{l}\text { Tarsos anteriors de } 4 \text { o 5 artells, però amb el primer sempre } \\
\text { molt menut i quasi invisible. Èlitres generalment truncats en } \\
\text { 1'àpex, a vegades dentats o denticulats (figura 7E). } \\
\text { Tarsos de 5 artells. Èlitres àmpliament arredonits en l'àpex, } \\
\text { sense dents ni espines (figura 7D). }\end{array}$ & Família Bostrichidae \\
\hline \multicolumn{2}{|l}{} \\
\hline
\end{tabular}




\section{Superfamília Cleroidea}

a $\quad$ Coxes davanteres voluminoses. Tarsos amb el primer artell no més curt que el segon, o quan ho és, amb alguns dels tarsòmers lobulats i l'empodi no visible. Antenes en general amb una maça de 3 artells, a vegades serrades o filiformes. Tarsos criptopentàmers o pentàmers amb làmines membranoses per la cara interior. Ungles senzilles (figura 8).

\section{Superfamília Cucujoidea}

Aquesta superfamília presenta un gran nombre de famílies i això comporta prou complexitat taxonòmica. Per simplificar el procés d'identificació només es mostren els caràcters finals que identifiquen les famílies més importants.

a Tarsos heteròmers (5-5-4). Insercions antenals ocultes sota un lòbul lateral de les genes, de manera que no es veu dorsalment la cavitat on s'inserta el primer artell. Cap curt $i$ èlitres normals. Cavitats coxals anteriors tancades per darrere (figures 9A i B).

b Tarsos pseudotrímers (4 artells però només se'n veuen 3, ja que el tercer és menut $\mathrm{i}$ es disposa entre els lòbuls del segon; 3-3-3). Antenes amb 11 artells i una maça de 3 artells. Cos hemisfèric o oval. Sutura frontoclipeal absent. Escudet visible. Cantons anteriors del metastern sense tocar les epipleures. Metaepistern en punta cap a davant. Ales membranoses presents (figura 10).

c En ambdós sexes tarsos amb 5-5-5 o 5-5-4 (quart artell molt menut o absent en els tarsos posteriors dels mascles). Tarsos amb el segon i el tercer artell no lobulat per sota, el primer més curt que el quart. Coxes anteriors i mitjanes arredonides, sense trocantins visibles. Cavitats coxals anteriors obertes per darrere, amb estretes extensions laterals $\mathrm{i}$ les intermèdies tancades per l'estern. Antenes quasi filiformes. Èlitres sense estries de punts i amb la sutura sempre present. Costats dels èlitres subparal-lels. Pronòtum a vegades amb una carena longitudinal sublateral. Cos aixafat dorsoventralment (figura 9C).

\section{Superfamília Chrysomeloidea}

1 Cap un poc més estret que el pronòtum, o si és menut, amb el primer artell de les antenes molt robust, els següents filiformes o setacis, rara vegada serrats o pectinats. Èlitres amb epipleures més o menys diferenciades.

Família Tenebrionidae

Família Coccinellidae

Família Cucujidae 


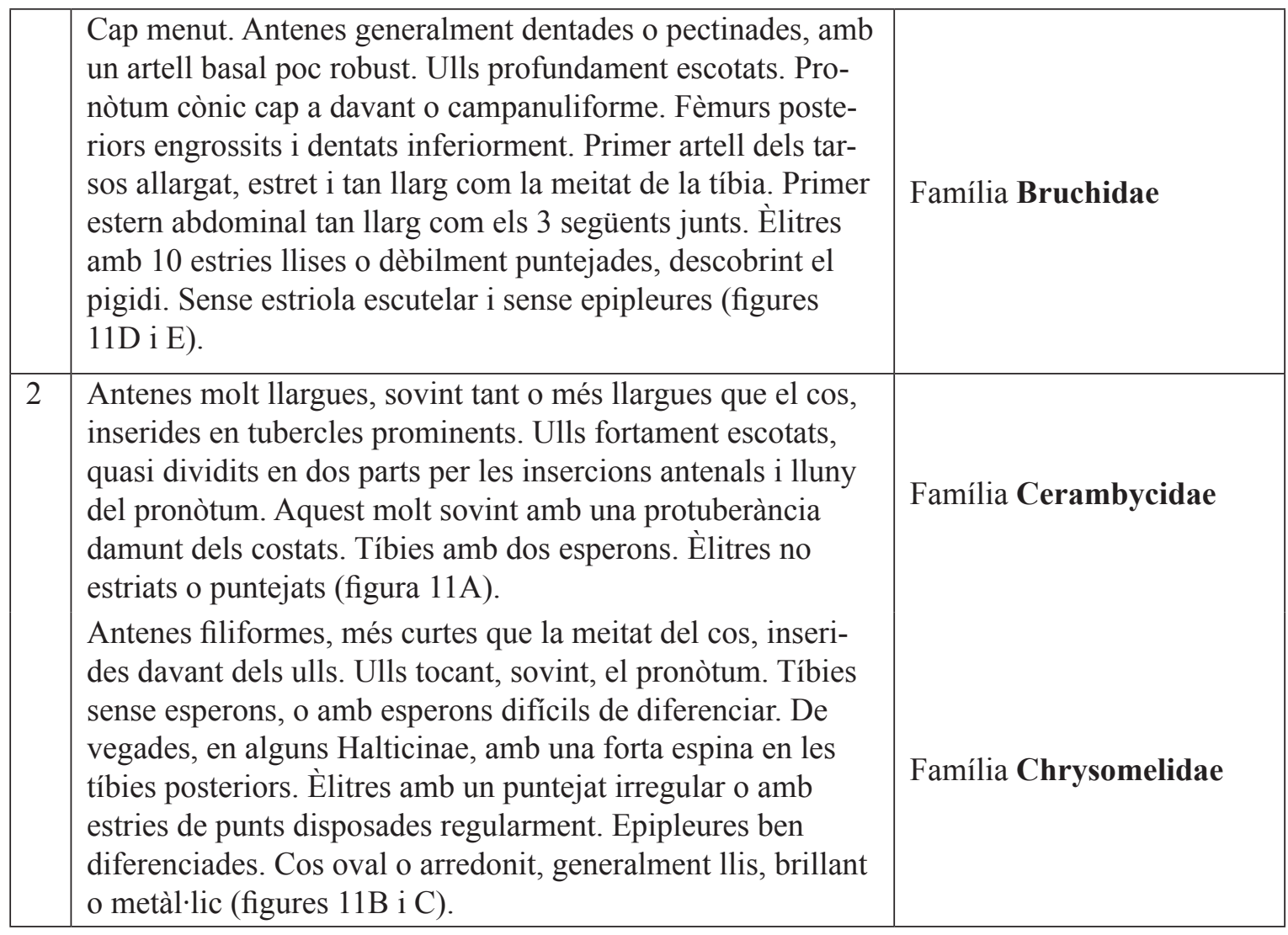

\section{Superfamília Curculionoidea}

\begin{tabular}{|l|l|l|}
\hline 1 & $\begin{array}{l}\text { Palps maxil·lars normals i flexibles. Labre separat. Maxil·les } \\
\text { amb lacínies diferenciades. }\end{array}$ & $\begin{array}{l}\text { Famílies Anthribidae } \\
\text { (micòfags) i Nemonychi- } \\
\text { dae (associats al pol·len de } \\
\text { coníferes) }\end{array}$ \\
2 & $\begin{array}{l}\text { Palps maxil·lars més o menys rígids. Labre no està mai verta- } \\
\text { derament lliure. Maxil·les sense lacínies diferenciades. }\end{array}$ \\
\hline 2 & $\begin{array}{l}\text { Palps maxil·lars de 4 artells. Antenes no geniculades mai, } \\
\text { maça de 3 artells. Èlitres amb estriola escutelar. Mandíbules } \\
\text { més o menys dentades en la vora externa. Longitud 3,5-7,5 } \\
\text { mm (figura 13B). } \\
\text { Palps maxil·lars de 2-3 artells. Antenes geniculades amb o } \\
\text { sense maça. Èlitres sense estriola escutelar. Mandíbules no } \\
\text { dentades en la vora externa. }\end{array}$ & $\begin{array}{l}\text { Família Attelabidae } \\
\text { plagues d'espècies llenyo- } \\
\text { ses) }\end{array}$ \\
\hline 3 & $\begin{array}{l}\text { Rostre rudimentari o absent. Tíbies anteriors comprimides, } \\
\text { generalment denticulades en la vorera externa. } \\
\text { Rostre ben desenvolupat, encara que pot ser curt i ample. } \\
\text { Tíbies anteriors no denticulades en la vorera externa. }\end{array}$ & 5 \\
\hline 4 & $\begin{array}{l}\text { Primer artell dels metatarsos quasi tan llarg com els altres } \\
\text { artells junts. Pronòtum amb solcs laterals per a la recepció } \\
\text { de les potes. Ulls redons i convexos. Cap tan ample com } \\
\text { el pronòtum. }\end{array}$ & $\begin{array}{l}\text { Família Platypodidae } \\
\text { (micòfags) }\end{array}$ \\
\hline
\end{tabular}




\begin{tabular}{|l|l|l|} 
& $\begin{array}{l}\text { Primer artell dels tarsos més curt que els tres següents junts. } \\
\text { Pronòtum sense lloc per a les potes. Ulls fortament trans- } \\
\text { versos o dividits en dos. Cap menys ample que el pronòtum } \\
\text { (figura 13A). }\end{array}$ & Família Scolytidae \\
\hline 5 & $\begin{array}{l}\text { Antenes en maça geniculades o no, amb l'escap molt curt. } \\
\text { Inserció antenal situada lateralment damunt del rostre. Pigidi } \\
\text { cobert pels èlitres. Trocànters llargs (figura 13C). }\end{array}$ & $\begin{array}{l}\text { Família Apionidae } \\
\text { (plagues d'espècies herbà- } \\
\text { cies) }\end{array}$ \\
$\begin{array}{l}\text { Antenes en maça sempre geniculades. Escaps de mida mode- } \\
\text { rada o extremament llarga. Inserció antenal apical o subapi- } \\
\text { cal. Trocànters curts (figura 12A-F). }\end{array}$ & Família Curculionidae \\
\hline
\end{tabular}

\section{Objectius de la pràctica}

Els objectius d'aquesta pràctica es concreten en tres:

1. Familiaritzar-se amb la morfologia dels coleòpters: tipus d'antenes, disposició de les potes, fórmula tarsal, etc.

2. Aprofundir en el grup més abundant i variat d'insectes.

3. Endinsar-se en la classificació baixant en les categories de classificació fins al nivell de subfamília en alguns casos.

\section{Desenvolupament de la pràctica}

\subsection{Material}

El material necessari per dur a terme aquesta pràctica és el mateix que s'ha emprat en la pràctica anterior:

- Col·lecció de coleòpters procedents de l'insectari del grup de Gestió Integrada de Plagues de la Universitat Jaume I o els agafats i portats al laboratori pel mateix estudiantat

- Lupa binocular

- Suros per clavar els insectes que cal observar

- Clau taxonòmica per identificar els coleòpters

\subsection{Metodologia}

A partir del material de què disposem (col·leccions d'insectes punxats), els prendrem individualment per identificar-los.

Desclavarem els coleòpters de la planxa on es troben i els clavarem sobre una peça de suro de 2 x $2 \mathrm{~cm}$ aproximadament per observar-los en la lupa binocular. Segons 
com clavem l'agulla al suro, podrem observar les estructures que ens interessen, tant de la cara superior com de la inferior o dels costats dels insectes. Sempre manipularem l'espècimen amb l'ajut del suro, ja que altrament podem fer-lo malbé en moure'l sota la lupa binocular sense adonar-nos-en. Cal tenir en compte que es tracta sempre d'insectes secs, molt fràgils, que se'ns trencaran si no els manipulem amb cura.

A continuació, i amb l'ajut de la lupa binocular i de la clau corresponent, caldrà que determinem les superfamílies, famílies o subfamílies dels coleòpters proporcionats. 


\section{PRÀCTICA 3}

\section{Observació i identificació dels ordres \\ i subordres d'àcars d'importància agronòmica}

\section{Antecedents}

\subsection{Generalitats dels àcars}

Els àcars pertanyen a la subclasse Acari, dins de la classe Arachnida (fílum Arthropoda). Es tracta d'organismes de mida reduïda, però de gran importància econòmica, tant pels danys que poden ocasionar a plantes i animals (inclòs l'home), com pels beneficis, en el cas d'aquells que s'alimenten d'organismes plaga i actuen com a enemics naturals.

Els àcars tenen en comú amb la resta de la classe Arachnida l'absència d'ales i d'antenes i la presència de quatre parells de potes, a excepció dels estadis larvaris, que en tenen tres, i dels àcars pertanyents a la família Eriophyidae, que en tenen dos durant tota la seua vida. Però, a diferència d'altres aràcnids, on el cos està dividit en dues regions diferenciades (cefalotòrax $i$ abdomen), en els àcars el cos és arredonit i no presenta una segmentació clara (figura 1). Tot i aixó, per facilitar-ne la identificació, s'acostuma a dividir artificialment el cos, en tres regions (figura 2): el gnatosoma, o regió anterior del cos on es troba l'aparell bucal amb dos parells d'apèndixs: els quelícers (que ocuparien el lloc de les antenes en els insectes) amb funció prènsil, perforadora i trituradora (figura 23), i a vegades transformats en estilets mitjançant els quals perforen els teixits i succionen els sucs vegetals; i els palps (o pedipalps), que són els òrgans sensorials tàctils i olfactius, i que poden tenir aspecte de pota, d'antena, ser quelats o fins i tot ser vestigials. En els quelícers dels mascles dels Mesostigmata (fitoseids, entre d'altres) s'hi pot observar una prolongació denominada espermatodàctil, mitjançant la qual agafen el paquet espermàtic (espermatòfor) de la seua obertura genital per transferir-lo a la de la femella (figura 23). La següent regió és el podosoma, i com el seu nom indica, és la zona on es fixen els quatre parells de potes. I finalment, l'opistosoma, que és l'ultima part del cos. El conjunt del podosoma i de l'opistosoma es denomina idiosoma. Alguns autors parlen de dues regions, el prosoma (que inclou el gnatosoma i el podosoma) i l'opistosoma. En cas de presentar ulls, aquests són simples i es disposen en el gnatosoma. L'idiosoma, al seu torn, pot dividir-se en propodosoma (regió del cos on estan inserits els dos primer parells de potes) i l'histerosoma (la resta del cos). Es poden fer encara més divisions, sempre amb finalitats identificatives, tal com es mostra a la figura 2. 


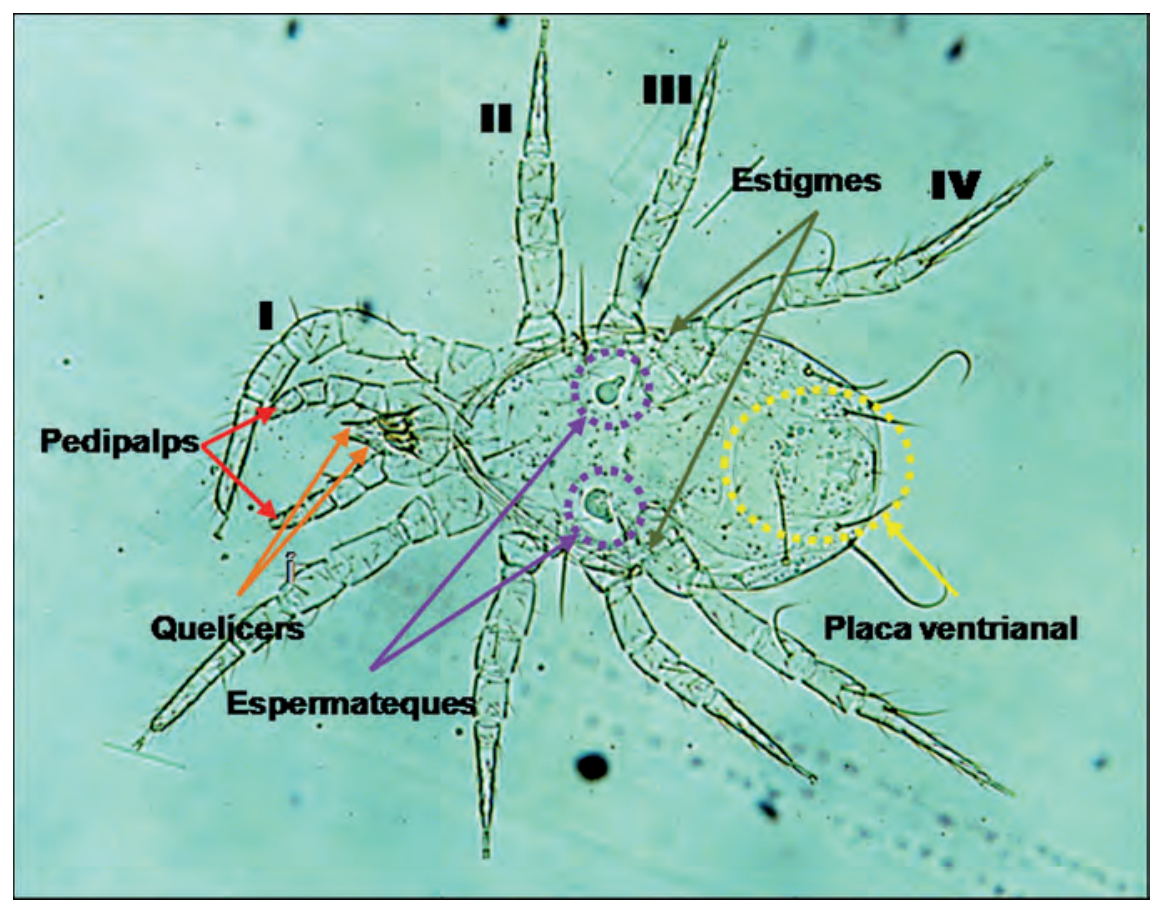

Figura 1. Aspecte d'un àcar fitoséid on es destaquen algunes de les estructures principals

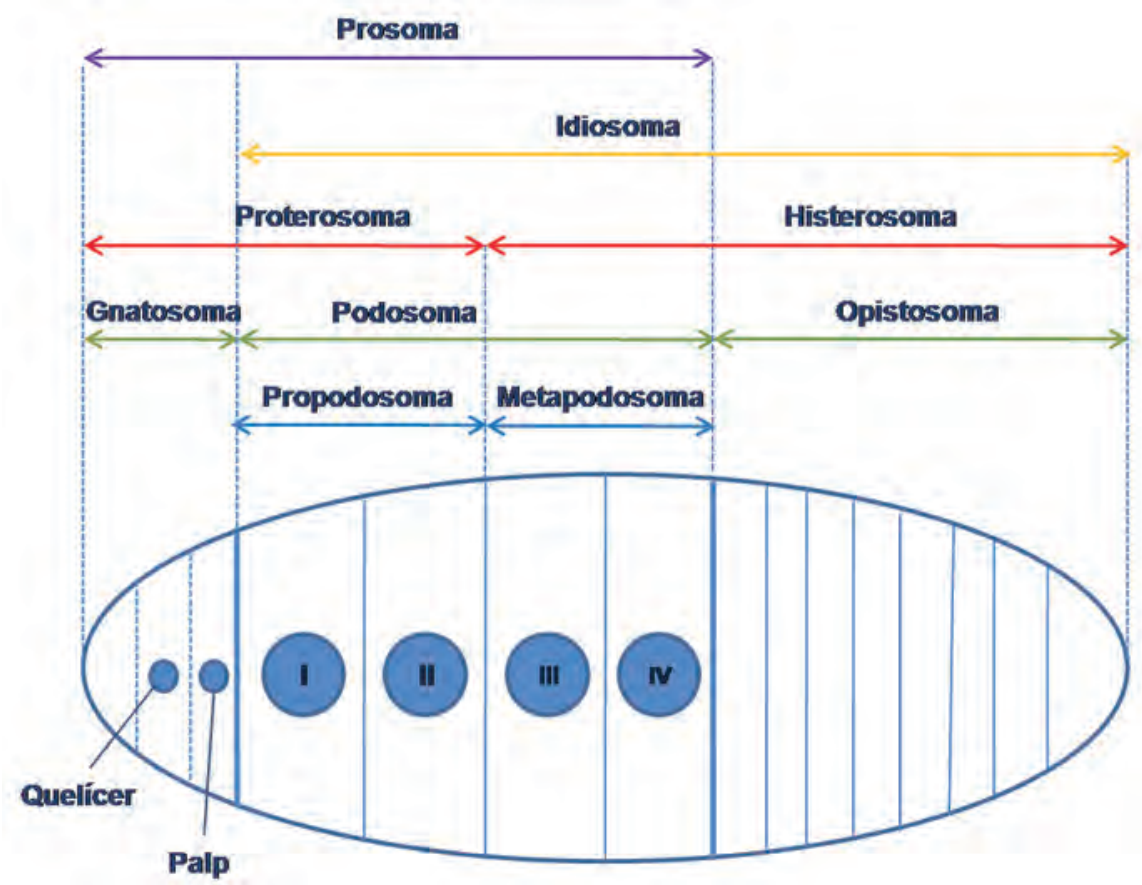

Figura 2. Vista lateral de les divisions artificials del cos dels àcars. Adaptat d'Iturrondobeitia (2004)

El cos dels àcars acostuma a estar recobert de sedes o quetes, que tenen gran valor taxonòmic, tant pel que fa al seu nombre com a l'aspecte o la distribució. A més, el cos pot estar més o menys endurit i formar plaques, en general dorsals, la forma de les quals també té valor taxonòmic (figura 3 ). 

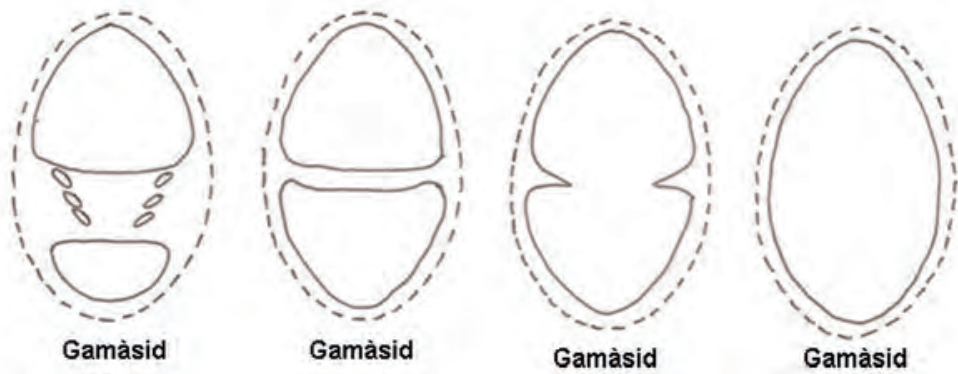

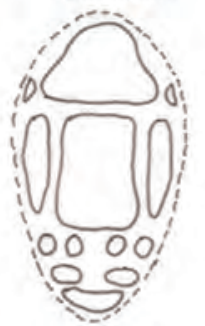

Actinèdid

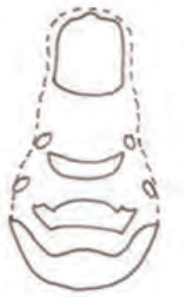

Oribàtid

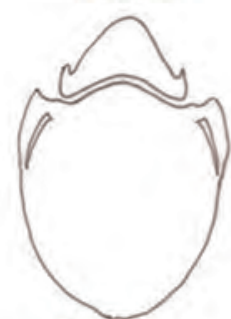

Oribàtid

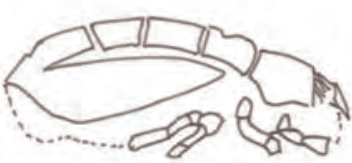

Oribàtid

Figura 3. Diferents tipus de plaques dorsals que es poden observar en alguns dels subordres. Adaptat d'Iturrondobeitia (2004)

La respiració és de tipus traqueal mitjançant estigmes (la posició, número i morfologia d'aquests s'empra en la separació dels principals grups d'àcars, figura 4), o de tipus tegumentari en aquells que no presenten estigmes (subordre Astigmata).
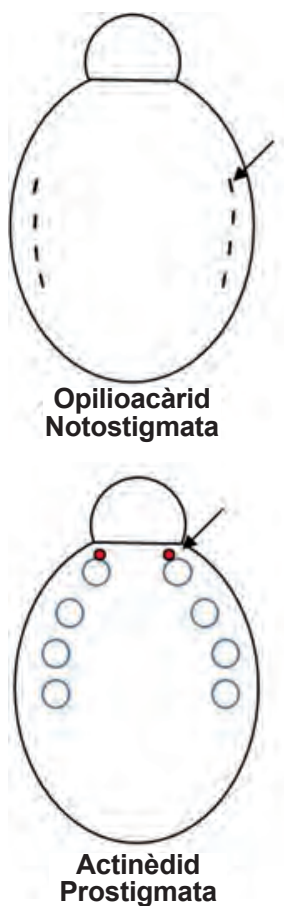
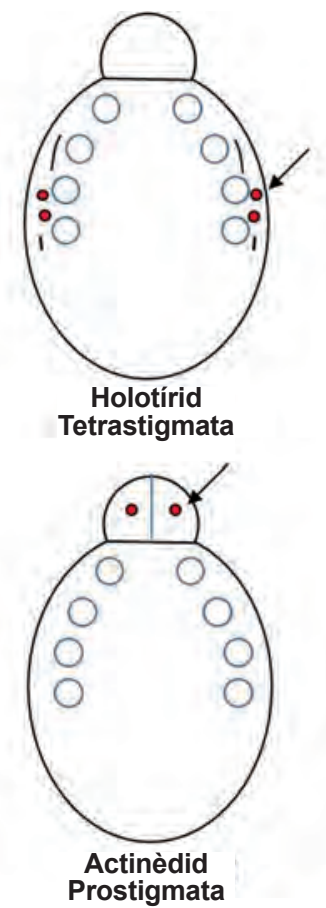
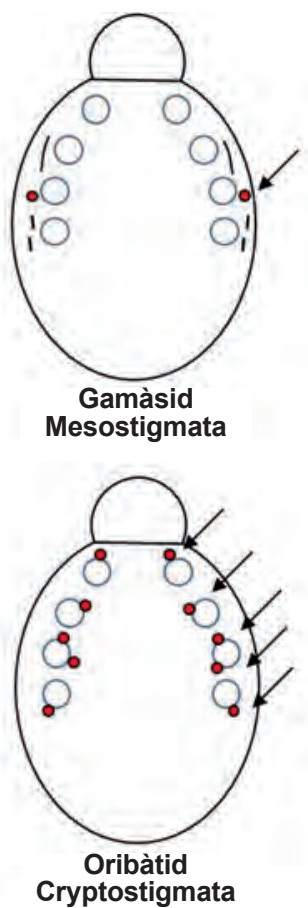
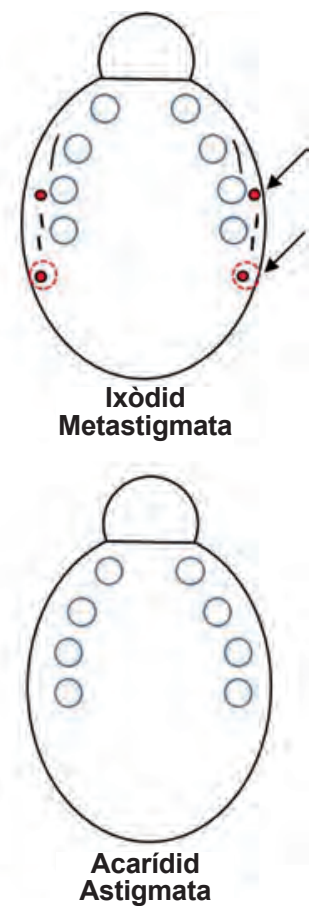

Figura 4. Posició dels estigmes en el cos dels àcars. Adaptat d'Iturrondobeitia (2004) 
La reproducció és de tipus sexual, i hi participen tots dos sexes, però també es donen casos de partenogènesi facultativa de tipus arrenotoc (producció de mascles a partir d'ous no fecundats) o de tipus telitoc (producció de femelles a partir d'ous no fecundats). La gran majoria dels àcars són ovípars, encara que també s'ha descrit la viviparitat en alguns casos.

Després de l'eclosió de l'ou, els àcars, com fan la resta d'artròpodes, muden al llarg del seu desenvolupament i passen l'estat de larva i nimfa fins a arribar a l'estat adult. Les nimfes passen per dos o tres estadis nimfals (protonimfa, deutonimfa, i, si n'hi ha, tritonimfa) separats per moments de quiescència (protocrisàlide, deutocrisàlide i teliocrisàlide, respectivament), que és quan es produeix la muda. Les larves tenen tres parells de potes, a diferència de les nimfes i els adults, que en tenen quatre.

Els àcars es poden trobar en qualsevol nínxol ecològic tot explotant gran varietat de recursos nutricis. En trobem de fitòfags, de sapròfags, de micòfags, de paràsits, de depredadors, etc. Els àcars fitòfags presenten els quelícers transformats en estilets, amb els quals perforen els teixits vegetals i succionen el contingut cel·lular, alterant la transpiració, la capacitat fotosintètica i el creixement normal del vegetal afectat. A més, en alguns casos, poden produir agalles o transmetre amb la saliva organismes fitopatògens. Els podem trobar a qualsevol òrgan de la planta, si bé aquells que es troben en la part aèria solen provocar problemes fitosanitaris més importants. Els fitòfags més especialitzats pertanyen a la família Tetranychidae i Eryophidae. Altres àcars (p. ex. Acarus siro L. o Tyrolichus casei Oudemans) estan especialitzats en productes emmagatzemats com la farina, el sucre, el formatge, el pernil salat... o en els microorganismes que creixen damunt la seua superfície (Tyrophagus putrescentiae (Schranck)). També en trobem de paràsits dels homes o dels animals, que els danyen directament (caparres, àcar de la sarna...) o indirectament, quan són vectors d'altres malalties. Per contra, hi ha un altre grup d'àcars que es considera útil en depredar altres artròpodes (àcars o insectes) i esdevenen de molta utilitat en programes de lluita biològica, com els pertanyents a la família Phytoseiidae (p. ex. Phytoseiulus persimilis Athias-Henriot per al control de l'aranya roja, Tetranychus urticae Koch; o Amblyseius swirskii Athias-Henriot per al control de trips, mosques blanques, ous de lepidòpters...). Tanmateix en aquesta pràctica ens centrarem fonamentalment en aquells que poden afectar els cultius.

\subsection{Classificació dels àcars}

En aquest manual seguirem la classificació establerta per Iturrondobeitia (2004) fins a la categoria de subordre, i només destacarem les famílies més importants amb hàbits fitòfags o depredadors. La classificació s'exposa en la figura 5. 


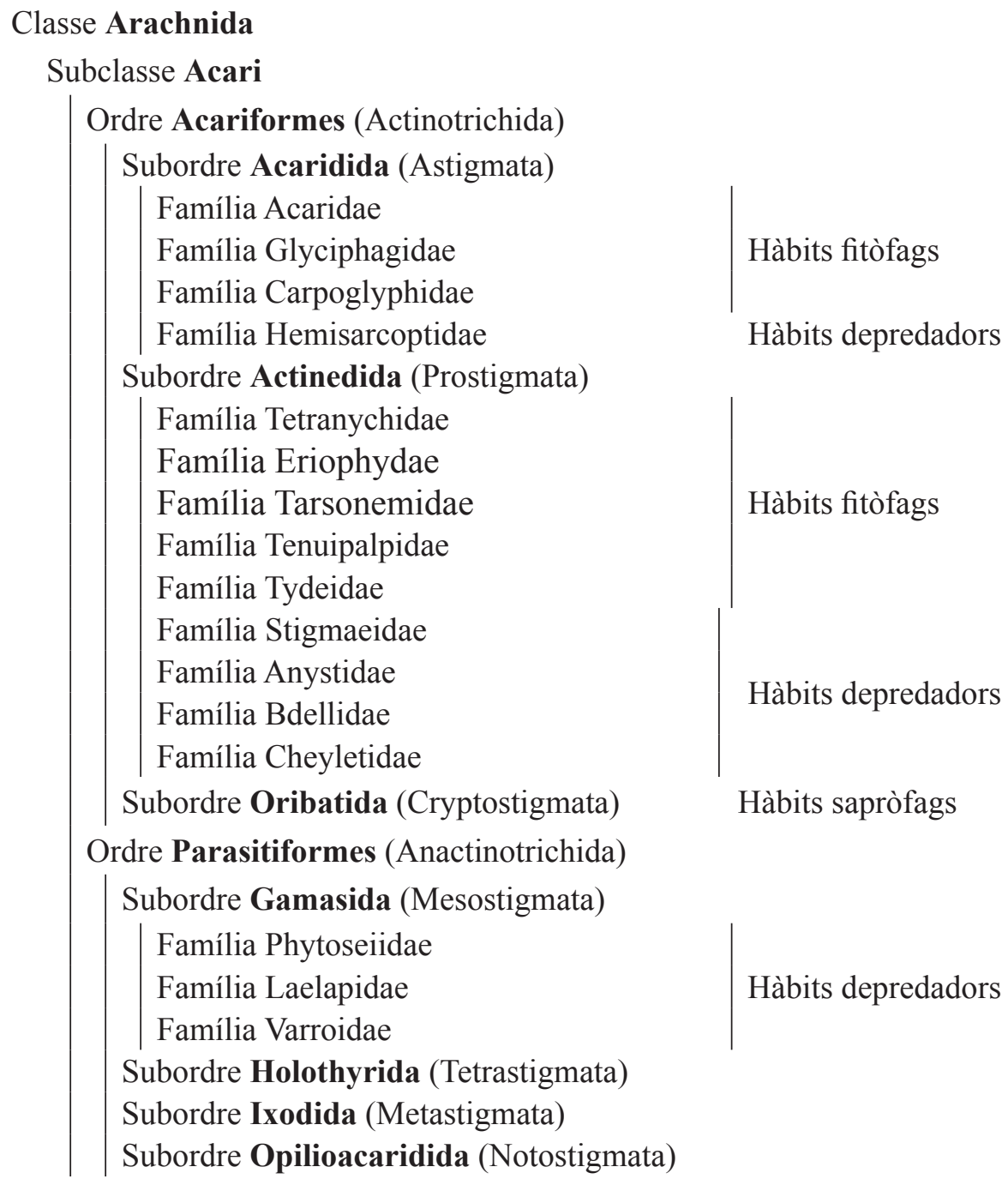

Figura 5. Classificació de la subclasse Acari fins a la categoria de subordre, on destaquen aquelles famílies amb interès agroforestal

Els noms dels ordres Actinotrichida o Anactinotrichida varen ser establerts per Grandjean en 1935 en funció de si presentaven en el cos sedes birefringents (actino-) o no (anactino-) a la llum polaritzada (Viñuela et al., 1996). Entre aquests dos ordres existeixen altres diferències, com la presència d'un plec sejugal que separa els dos primers parells de potes dels dos següents, les coxes fusionades de dos en dos i l'orifici genital longitudinal en els Actinotrichida, mentre que en els Anactinotrichida no existeix divisió del cos, les coxes estan lliures ventralment i l'orifici genital és transversal (Viñuela et al., 1996) (figura 6). 


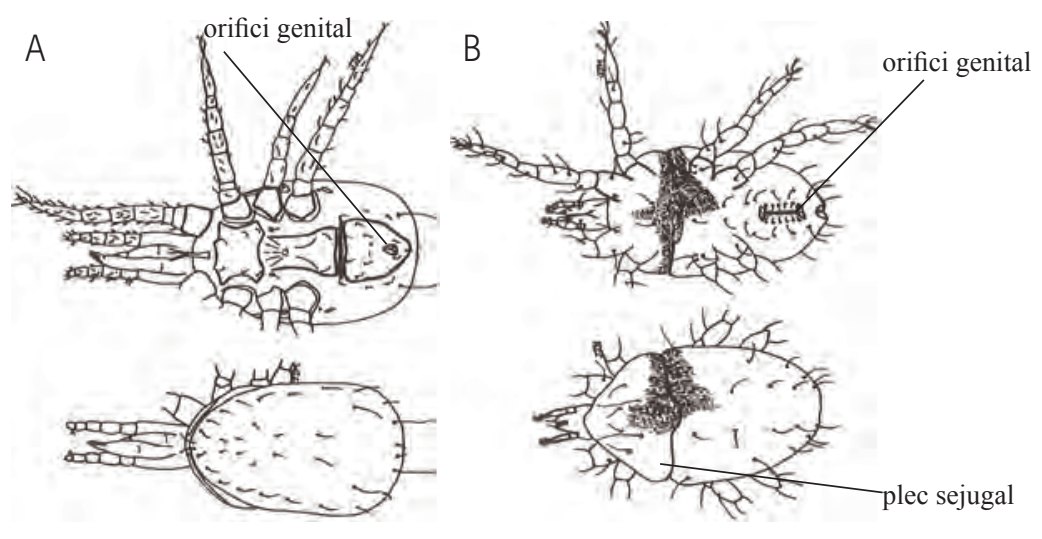

Figura 6. Dibuixos on es poden observar els trets principals que separen els àcars pertanyents a l'ordre Anactinotrichida (A) i Actinotrichida (B)

De l'esquema proposat anteriorment, els holotírids, els ixòdids i els opilioacàrids tenen escàs interès agroforestal, mentre que els actinèdids i els acarídids, per contra, tenen un gran nombre d'espècies fitòfagues, i els gamàsida, de depredadores, $\mathrm{i}$ seran aquests els que passarem a estudiar amb més detall a continuació.

\subsection{Característiques de les principals famílies d'interès agroforestal}

\subsubsection{Ordre Acariformes (Actinotrichida)}

\section{Subordre Acaridida}

Dins de la família Acaridae trobem des d'espècies d'escassa importància econòmica (sapròfagues, micòfagues...) fins a d'altres que causen seriosos danys quan creixen damunt d'aliments o productes emmagatzemats i s'alimenten directament d'ells o dels fongs que hi creixen; fins i tot trobem algunes espècies que poden ser beneficioses per als cultius. Un exemple és Tyrophagus putrescentiae, plaga típica de gra emmagatzemat, formatges, llocs de cultius de bolets, cultius de fongs en laboratori... però que alhora és eficient en el control d'alguns escarabeids plaga (Diabrotica undecimpunctata howardii Barber) o de l'hemípter que causa la filloxera (Daktulosphaera vitifolii (Fitch)) (figura 7). En alguns casos s'ha vist que els acàrids poden ser portadors de fongs entomopatògens que ajuden en el control d'altres plagues (Gerson et al., 2003). Els Acaridae son àcars de color blanquinós brillant amb llargues sedes i que es desplacen mitjançant moviments molt lents. 

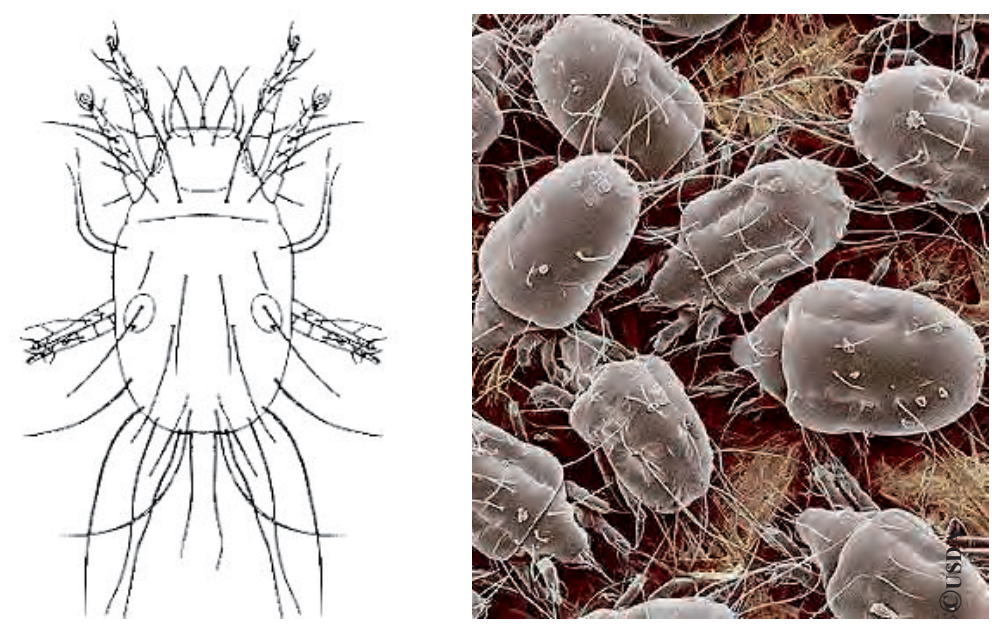

Figura 7. Dibuix de l'acàrid Tyrolichus casei (esquerra) i imatge de microscòpia electrònica de Tyrophagus putrescentiae (dreta)

Dins de la família Carpoglyphidae destaca l'espècie Carpoglyphus lactis (L.), que ataca els fruits secs, i dins de la Glyciphagidae Glyciphagus domesticus (De Geer), espècie polífaga present en la pols i en els grans emmagatzemats (figura 8).
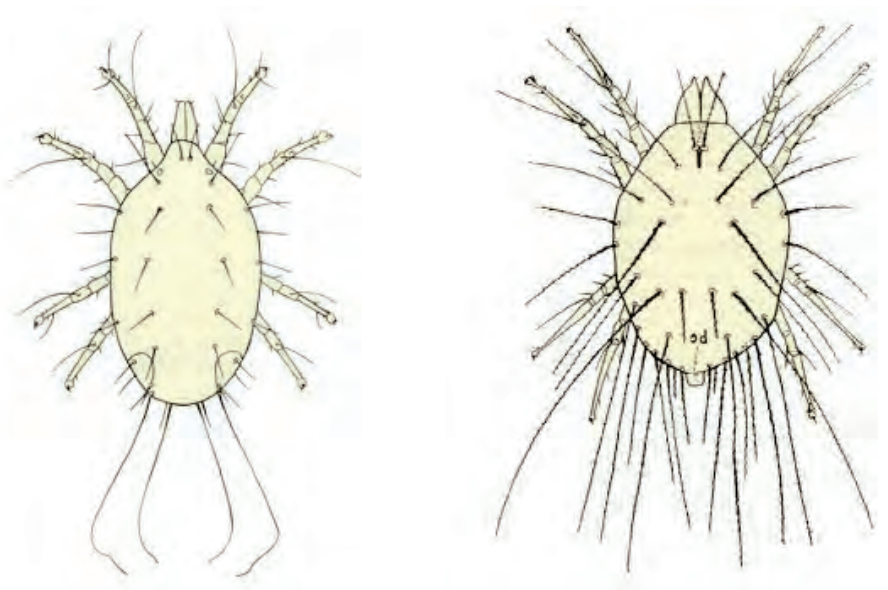

Figura 8. Dibuixos dels acàrids Carpoglyphus lactis (esquerra) i Glyciphagus domesticus (dreta)

En la família Hemisarcoptidae tan sols s'ha estudiat la biologia del gènere Hemisarcoptes. Es tracta d'espècies menudes de color blanquinós de gran eficàcia en el control d'hemípters diaspídids com Hemisarcoptes malus (Shimer), capaç de reduir les poblacions de la serpeta Lepidosaphes ulmi (L.) (Gerson et al., 2003), o Hemisarcoptes cooremani Thomas, agent potencial de control del poll roig de Califòrnia, Aonidiella aurantii (Maskell) (Luck et al., 1999), totes dues espècies plaga molt importants de pomeres i cítrics, respectivament (figura 9). 


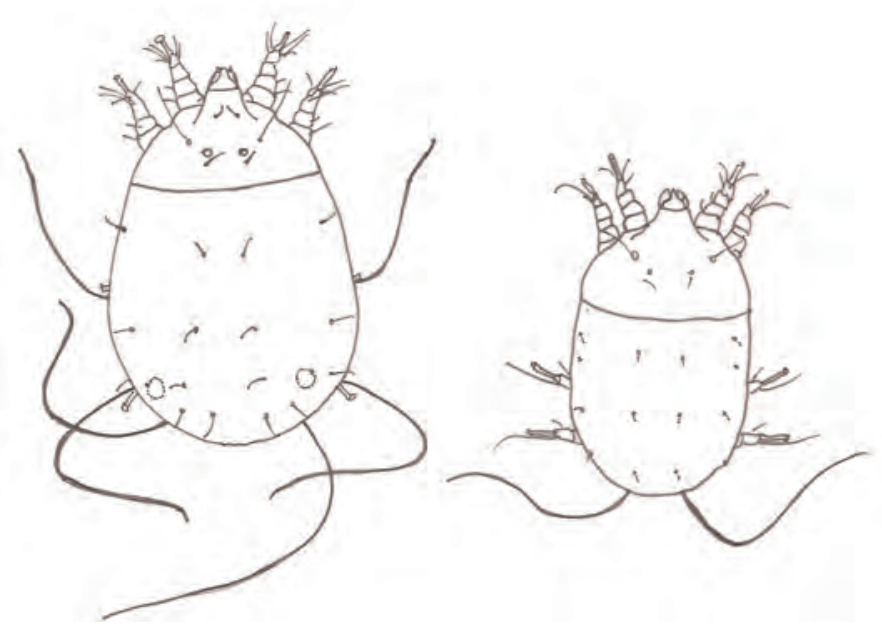

Figura 9. Femella (esquerra) i mascle (dreta) d'Hemisarcoptes sp.

\section{Subordre Actinedida}

Dins d'aquest subordre, amb hàbitats fitòfags, destaca la família Tetranychidae (aranyes $\mathrm{i}$ àcars rojos, grocs $\mathrm{i}$ verds), la qual conforma un grup molt nombrós d'espècies, sent-ne la majoria espècies fitòfagues $i$ amb mides al voltant dels 0,5 $\mathrm{mm}$. Encara que la majoria dels tetraníquids son monòfags o tenen un rang molt estret d'hostes, com Panonychus citri (McGregor), que només s'alimenta de cítrics i altres rutàcies, o Panonychus ulmi (Koch), que ho fa només de rosàcies, les principals espècies plaga destaquen per l'àmplia polifàgia, com Tetranychus urticae, que s'ha descrit en més de 1.000 espècies vegetals a les que causa greus danys (figura 10).
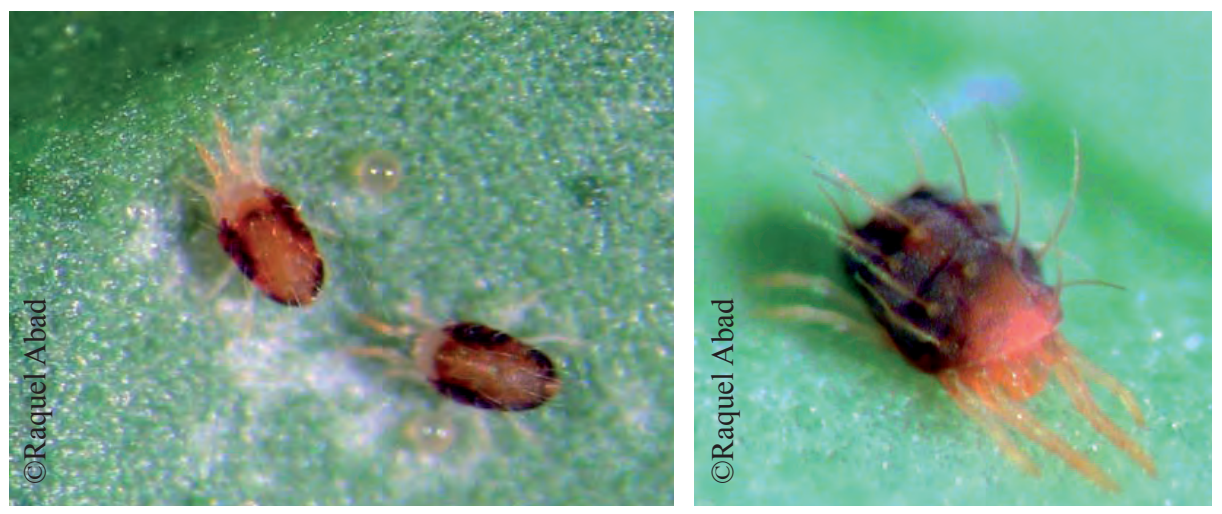

Figura 10. Adults de Tetranychus urticae (esquerra) i de Panonychus citri (dreta)

Les fulles atacades pels tetraníquids mostren taquetes translúcides, que es transformen en àrees platejades o verd pàl·lid (cloròtiques) a causa de l'eliminació dels cloroplasts. Posteriorment aquestes àrees s'oxiden i donen unes tonalitats daurades, que en casos d'atacs intensos poden acabar esdevenint taques necròtiques. Una característica de la subfamília Tetranychinae és la producció d'abundant 
teranyina, que modifica les condicions microclimàtiques de l'hàbitat, i que afecta l'establiment d'altres espècies fitòfagues, així com el control per part dels enemics naturals, a més de protegir la colònia de tractaments químics, de la pluja, etc.

En aquesta família hi ha descrites espècies plaga tan importants com la ja esmentada aranya roja, $T$. urticae, molt polífaga i cosmopolita, considerada com el tetraníquid més perjudicial a nivell mundial tant en plantes herbàcies com llenyoses a l'aire lliure i en hivernacles (Abad et al., 2009a). Aquesta se situa a l'anvers de la fulla on forma les teranyines i provoca unes taques cloròtiques que, en el cas dels cítrics, quan es manifesten al fruit, en disminueixen el valor comercial (figura 11). En cas d'atacs greus, conjuntament amb fenòmens d'estrès hídric, poden produir defoliacions completes dels arbres afectats i arribar a matar-los (Aucejo et al., 2004). Aquesta aranya està considerada com una de les plagues més greus dels cítrics de la província de Castelló, on ataca fonamentalment els clementins, però també altres grups de cítrics (Aucejo et al., 2003).
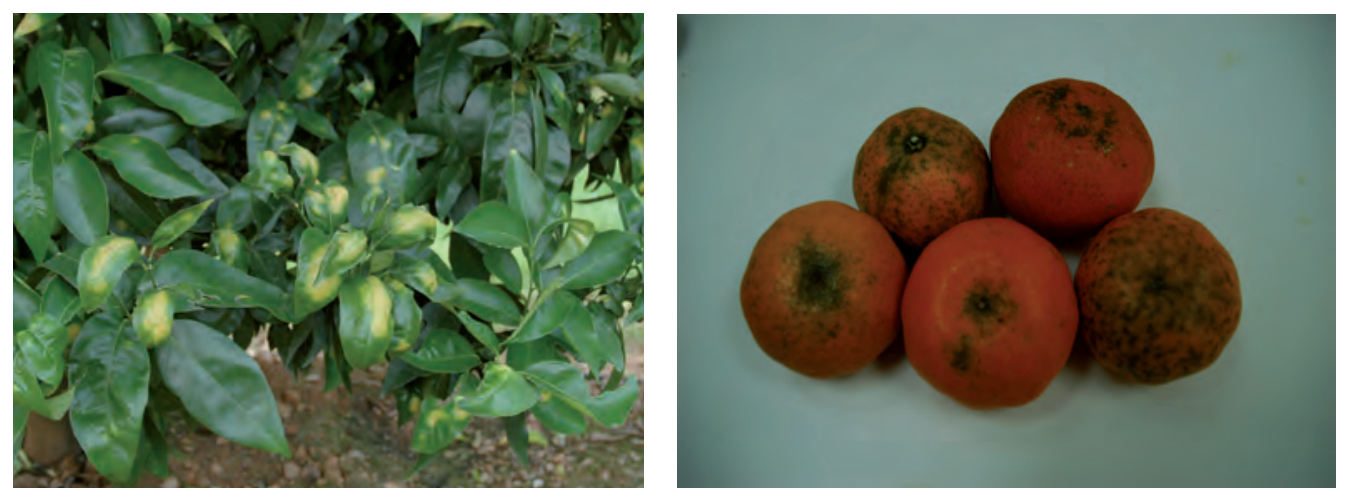

Figura 11. Dany de Tetranychus urticae en fulla (esquerra) i en fruit de clementí (dreta)

En aquesta família també hi trobem altres espècies plaga com Tetranychus evansi Baker i Pritchard, espècie plaga de solanàcies (tomaca, creïlla, albergínia...) o Oligonychus perseae (Tuttle, Baker i Abbatiello), que afecta l'alvocat. Altres gèneres importants dins d'aquesta família són Eotetranychus, Eutetranychus, i Petrobia (De Moraes i Flechtmann, 2008; Abad-Moyano et al., 2009a) (figura 12).
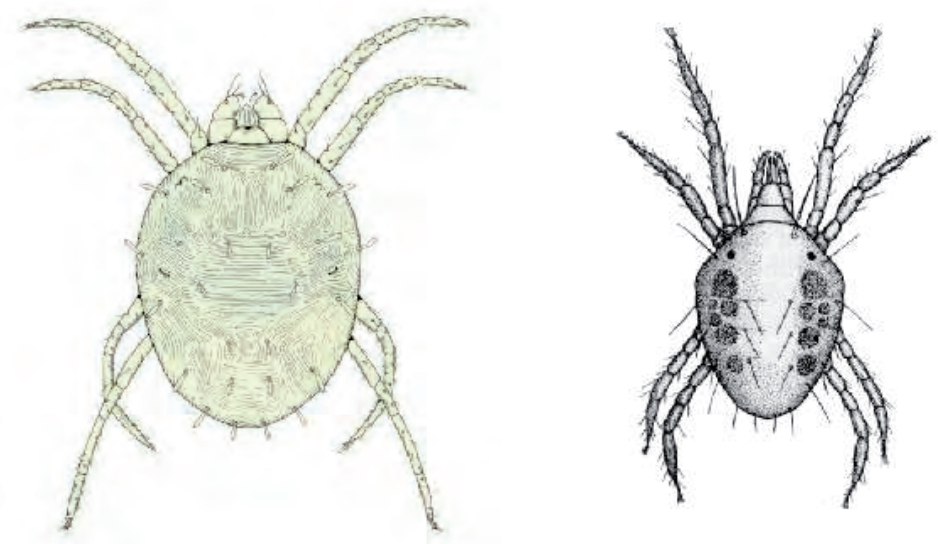

Figura 12. Dibuixos d'Eutetranychus orientalis (Klein) (esquerra) i de Tetranychus cinnabarinus (Boisduval) (dreta), dues espècies de tetraníquids plaga 
Els representants de la família Eriophydae, igual que els tetraníquids, també s'alimenten de les cèl·lules epidèrmiques dels vegetals, però aquesta alimentació no produeix un dany considerable i sí una modificació del creixement dels teixits, que formen agalles (en les espècies cecidògenes), pústules, erinosis (proliferació anormal de tricomes), malformació de borrons, enrotllament i mort del teixit que l'envolta. Els eriòfids són àcars molt menuts, d'aspecte vermiforme i amb poques sedes corporals, amb dos parells de potes i molt específics, de manera que només són capaços d'alimentar-se d'una única espècie vegetal (o de diverses espècies d'un únic gènere), i en una única planta a causa de la seua reduïda capacitat de dispersió. Acostumen a viure en llocs confinats com ara borrons, brots terminals, agalles, etc. (Gerson et al., 2003; De Moraes i Flechtmann, 2008). Hi ha nombroses espècies plaga, com Aculops lycopersici (Massee), espècie plaga responsable de l'acariosi bronzejada de les tomaqueres, que els provoca ràpidament la mort (Viñuela i Jacas, 1998); Aculus schlechtendali (Nalepa), àcar de l'acariosi bronzejada de la pomera; Aculus fockeui Nalepa i Trouessar, àcar de l'acariosi argentada de la bresquilla; Colomerus vitis (Pagenstecher), causant de l'erinosi de la vinya, que origina deformacions en les plantes i fulles a més de raïms de menor mida, deformes o inexistents; Eriophyes sheldoni (Ewing), àcar dels borrons de la llimera, que deforma els fruits atacats de manera molt cridanera (figura 13) i Phytocoptella avellanae Nalepa, el badoc de l'avellaner, que n'ataca els borrons, els unfla i els deforma (García-Marí et al., 1991; Viñuela i Jacas, 1998).

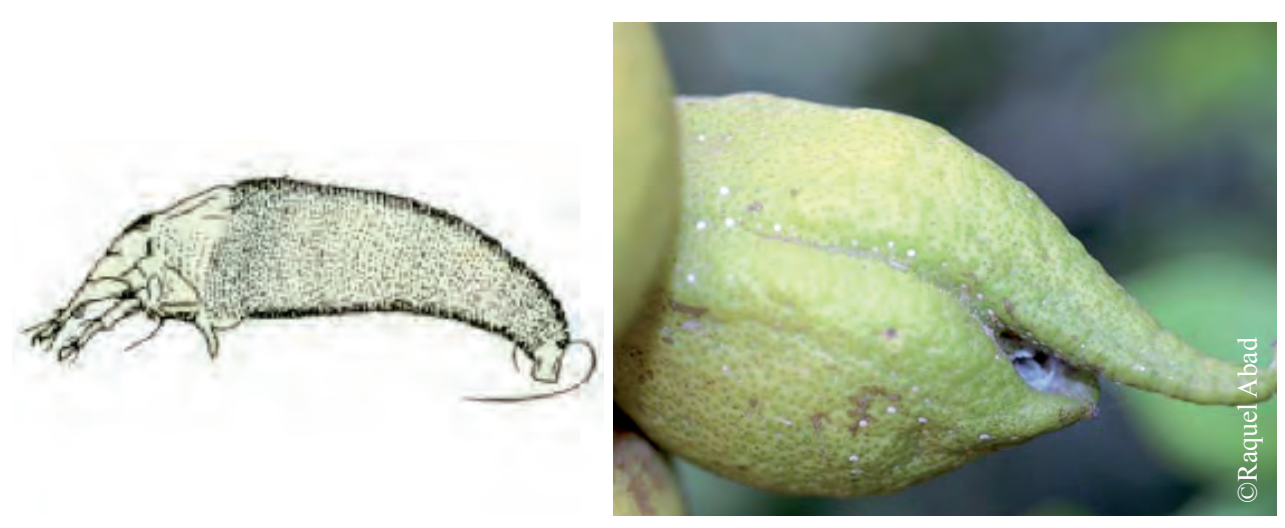

Figura 13. Dibuix de l'eriòfid Eriophyes sheldoni (esquerra) i deformació que provoca en la llimera (dreta)

Algunes espècies es consideren beneficioses en controlar males herbes, com ara Aculus hyperici (Liro), que s'utilitza com a agent de control biològic contra el pericó o herba de Sant Joan (Hypericum perforatum L.) a Austràlia, o Aceria malherbae Nuzzaci contra la correjola Convolvulus arvensis L. als EUA (Gerson et al., 2003; Lauriault et al., 2004) (figura 14). Aquest últim és l'únic àcar que es comercialitza per al control de males herbes. D'altres poden alentir el desenvolupament d'algunes espècies plaga o serveixen per alimentar altres àcars beneficiosos en cries comercials massives abaratint-ne el cost. 


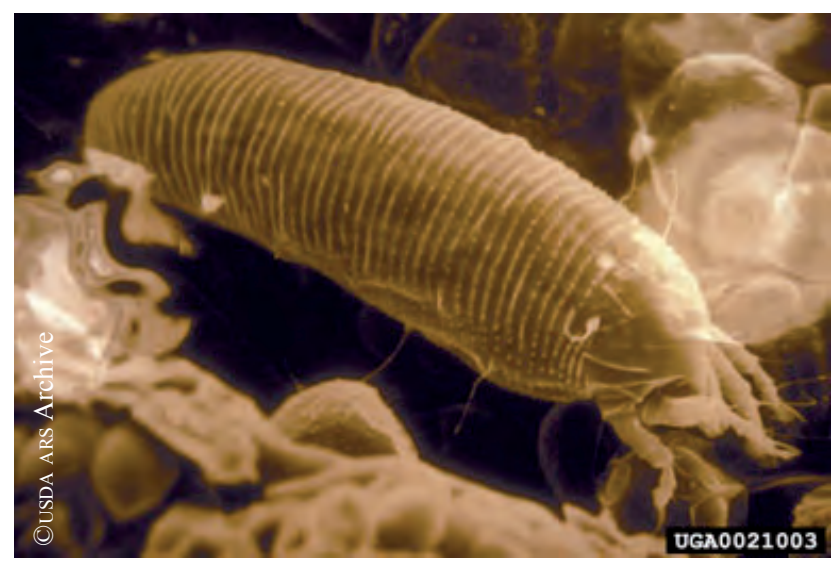

Figura 14. Imatge de microscòpia electrònica de l'eriòfid Aceria malherbae

La família Tarsonemidae està formada per àcars de mida molt reduïda (100-300 $\mu \mathrm{m})$, amb el cos allargat o ample, coloració de blanquinosa a groguenca i tegument molt endurit (figura 15). Presenten règims alimentaris molt variats: des de fongs, algues o plantes vasculars fins a comportar-se com a espècies depredadores d'insectes. Acostumen a atacar els llocs de creixement de la planta. El primer senyal de la seua presència és una decoloració $i$ un argentat o bronzejat dels teixits. Les fulles noves queden estretes, rígides, tortes i enrotllen els costats. Quan les plantes pateixen atacs greus, paralitzen el seu creixement, i poden arribar a morir. Dues espècies clau són l'aranya blanca Polyphagotarsonemus latus (Banks), altament polífaga i que ataca més de 100 espècies vegetals, i Steneotarsonemus pallidus (Banks), plaga clau del cultiu del maduixot (García-Marí et al., 1991; Gerson, 1992).
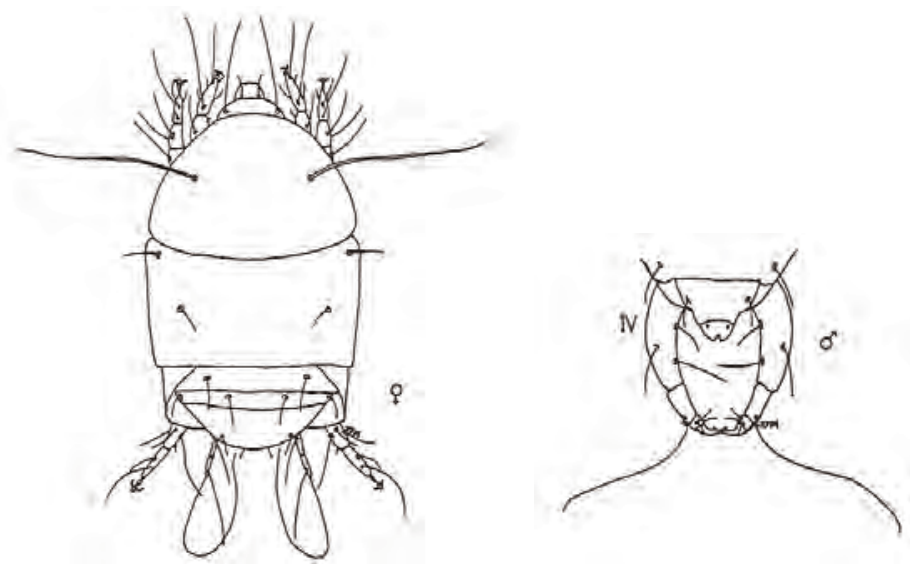

Figura 15. Dibuix d'un tarsomèmid femella (esquerra) i esquema de l'extrem final del tarsonèmid mascle que mostra l'últim parell de potes adaptat a retenir la femella durant la còpula (dreta)

Els àcars tenuipàlpids (família Tenuipalpidae) es coneixen amb el nom d'àcars plans o falsos tetraníquids a causa de la seua semblança amb els tetraníquids i dels seus colors rogencs o verdosos, si bé aquests són més xicotets $(0,2-0,3 \mathrm{~mm})$ i presenten el cos aixafat dorsoventralment (figura 16). S'alimenten de la cara interna de les fulles, pròxima als nervis, $i$ els provoquen uns danys similars als 
dels tetraníquids. La seua importància com a espècies plaga rau en el fet que alguns poden actuar com a vectors de virus, com Brevipalpus phoenicis (Geijskes), vector de la leprosi dels cítrics, que a més injecta substàncies tòxiques a la planta en alimentar-se'n.

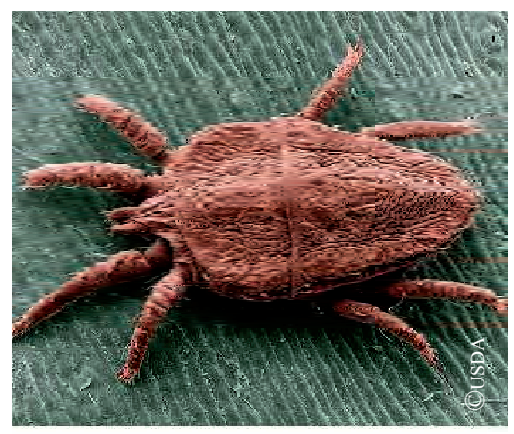

Figura 16. Imatge de microscòpia electrònica del tenuipàlpid Brevipalpus phoenicis

La família Tydeidae és molt abundant en les plantes i es troba associada a poblacions de còccids o altres insectes productors de melassa. No es considera una família amb espècies fitòfagues, si bé alguns autors han descrit Lorryia formosa Cooreman i Tydeus californicus (Banks) alimentant-se de fulles de cítrics (De Moraes i Flechtmann, 2008) (figura 17). Algunes espècies s'han descrit com a enemics naturals d'àcars plaga, altres com a preses de diferents fitoseids, com a consumidores de fongs, i fins i tot de nematodes (Gerson et al., 2003).

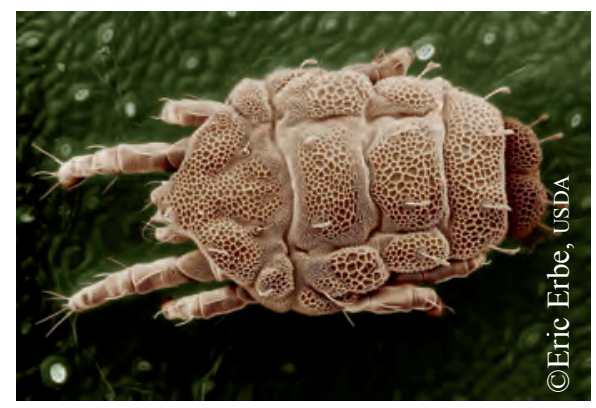

Figura 17. Imatge de microscòpia electrònica del tideid Lorryia formosa

Dins del subordre Actinedida s'agrupen quatre famílies amb hàbits depredadors, com ara la família Stigmaeidae, que inclou àcars amb el cos de roig a groc, ovoides o allargats amb el dors sovint cobert amb una o més plaques (figura 18). Acostumen a viure a les plantes o a terra alimentant-se dels ous i de les formes sèssils de tetraníquids, tenuipàlpids i altres espècies d'àcars que ataquen cultius. Algunes espècies també depreden cotxinilles o mosques. Es consideren el segon grup més important d'àcars depredadors després dels fitoseids, sobretot els gèneres Agistemus i Zetzellia. Els àcars d'aquest últim gènere, coneguts com a àcars de vellut per l'aspecte del seu cos, són relativament freqüents en diferents conreus. 


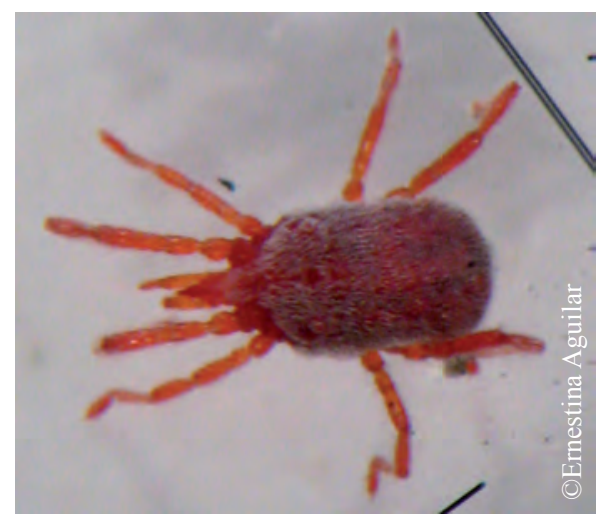

Figura 18. Aspecte general d'un stigmeid adult

Entre els Anystidae destaca el gènere Anystis, depredador de grans mesures (0,5$1,5 \mathrm{~mm}$ ), de color rogenc i abundant en sòls i plantes, que pot alimentar-se d'un gran nombre d'artròpodes com psocòpters, trips, col·lèmbols, mírids, cicadèl·lids, psíllids, pugons, cotxinilles, lepidòpters i dípters (Gerson et al., 2003) (figura 19).

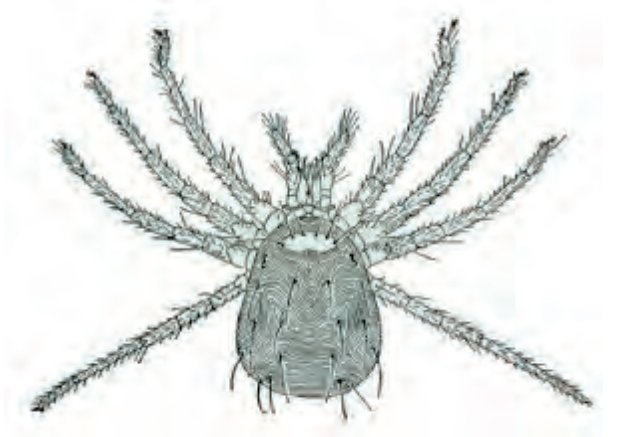

Figura 19. Dibuix de l'anístid Anystis baccarum (L.)

Els Bdellidae són depredadors relativament grans (fins a $4 \mathrm{~mm}$ ) que es caracteritzen per presentar les peces bucals allargades, amb un aspecte que recorda el dels curculiònids (morruts). Es poden trobar a les plantes, a terra i també en productes emmagatzemats alimentant-se de col-lèmbols, cotxinilles o àcars com $T$. urticae (figura 20) (Gerson et al., 2003).

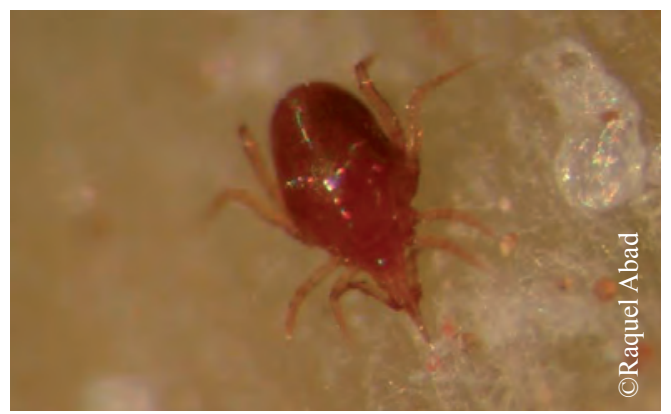

Figura 20. Adult que pertany a la família Bdellidae i depreda ous de tetraníquid 
A la família Cheyletidae trobem espècies depredadores d'àcars i d'insectes menuts i paràsits de mamífers, ocells i insectes. Hi destaca el gènere Cheyletus amb espècies depredadores d'àcars de productes emmagatzemats com A. siro, T. putrescentiae o l'àcar de la pols, Dermatophagoides pteronyssinus (Trouessart) (figura 21). No obstant això, alguns queilètids, quan coexisteixen amb altres depredadors com els fitoseids, poden eliminar-los fent-ne disminuir la capacitat depredadora (Gerson et al., 2003).

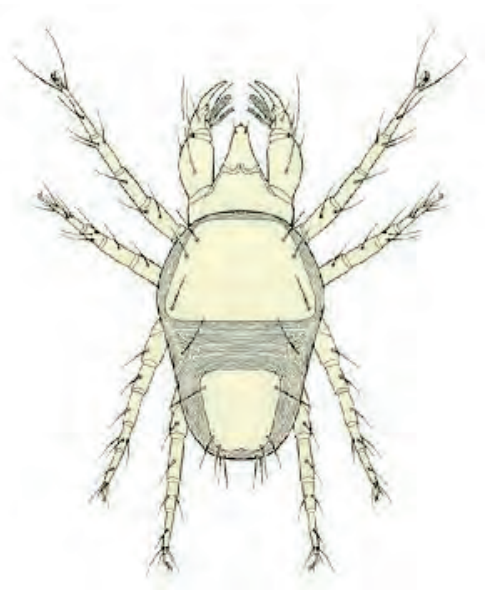

Figura 21. Dibuix del queilètid adult Cheyletus eruditis (Schrank)

\section{Subordre Oribatida}

Aquest subordre està format per àcars de 0,3 a 0,6 $\mathrm{mm}$ que pertanyen a la mesofauna edàfica i que tenen un paper molt important com a milloradors del sòl. Tenen el cos molt esclerotitzat, fins l'extrem que alguns es coneixen com a àcars escarabat (figura 22). Són importants a causa de la seua intervenció en la millora de la fertilitat del sòl (intervenen en la descomposició de la matèria orgànica i en el cicle del calci) o en la restauració de sòls deteriorats, per la qual cosa s'empren com a bioindicadors.
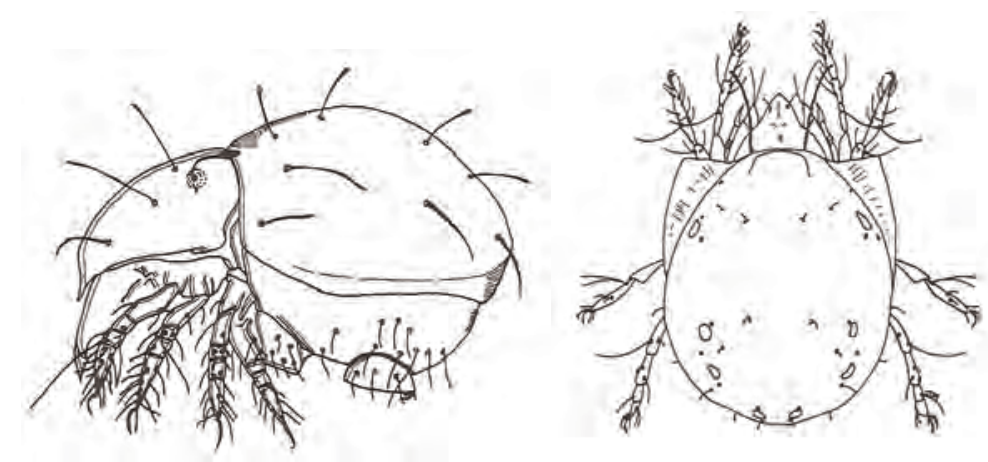

Figura 22. Dibuixos d'àcars oribàtids en els quals es pot intuir la forta esclerotització 


\subsubsection{Ordre Parasitiformes (Anactinotrichida)}

\section{Subordre Gamasida}

La família Phtyoseiidae està formada per àcars depredadors de gran importància agrícola per la seua capacitat de controlar les poblacions d'altres àcars plaga com ara tetraníquids, tenuipàlpids, tarsonèmids, tideids, eriòfids, acàrids, però també trips, mosques blanques, psocòpters, fongs, nematodes, etc. Tanmateix, algunes espècies poden sobreviure alimentant-se de pol·len o de substàncies sucroses produïdes per les plantes o altres insectes (Ferragut et al., 2010).

La mida acostuma a ser similar a la dels tetraníquids $(0,3-0,5 \mathrm{~mm})$ però tenen una velocitat de desenvolupament major. En aquestes espècies existeix un fort dimorfisme sexual. Els quelícers són raptors amb la típica forma de pinça i amb un estilet salivar a la part ventral (figura 23). Als quelícers dels mascles podem observar-hi l'espermatodàctil (òrgan en forma d'agulla o dit que serveix per transferir el paquet espermàtic fins l'orifici genital de la femella) (figura 23). Entre el tercer i quart parell de potes es pot veure l'estigma amb el seu peritrema, i en les femelles s'hi obri l'espermateca (figura 24). La forma de l'espermateca és variable i té un gran valor taxonòmic, juntament amb la distribució de les sedes dorsals (mai n'hi ha més de 20 parells), laterals i ventrals i amb la forma de la placa ventrianal (figura 25).
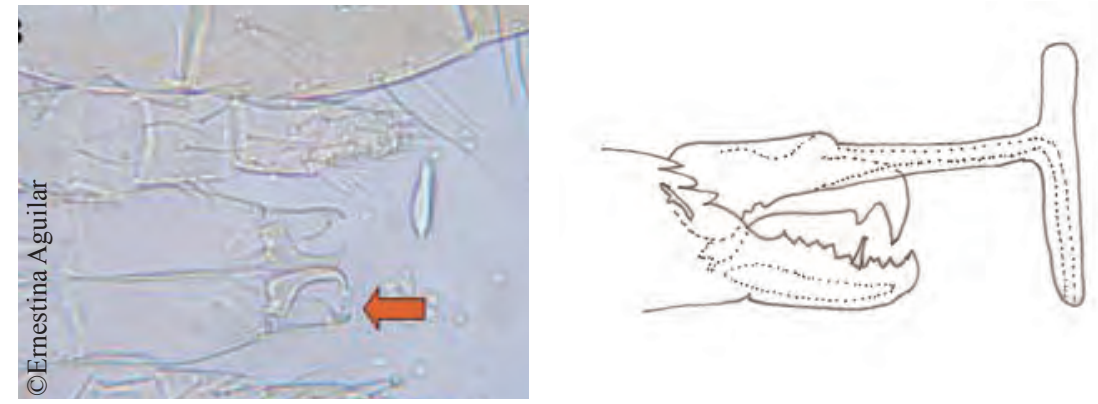

Figura 23. A l'esquerra, amb una fletxa s'indiquen els quelícers en forma de pinça dels fitoseids; a la dreta, dibuix de l'espermatodàctil en el quelícer del mascle (adaptat de De Moraes i Flechtmann, 2008)

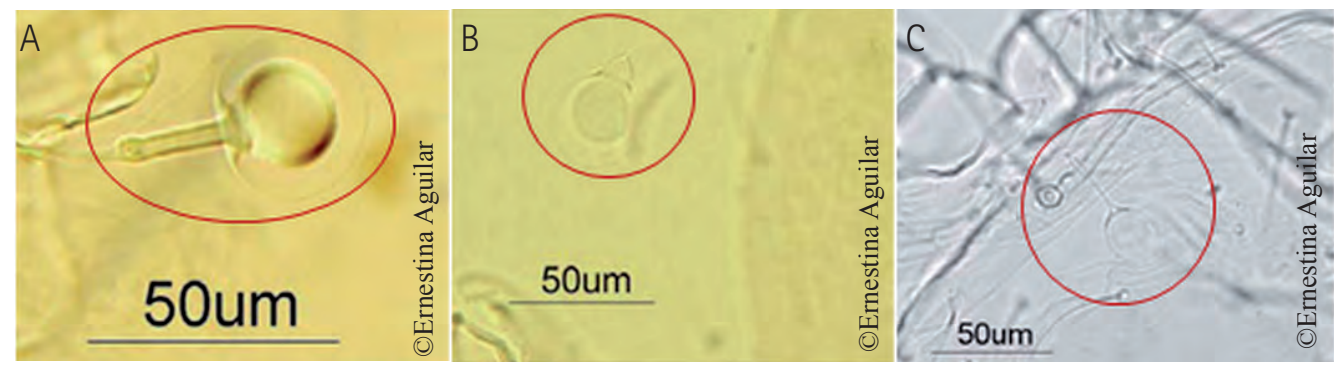

Figura 24. Amb un cercle es marca la posició de les espermateques de tres de les espècies més importants de fitoseids: Euseius stipulatus (A); Neoseiulus californicus (B) i Phytoseiulus persimilis (C). Aquesta estructura, en forma de sac, serveix a la femella per emmagatzemar l'esperma i es troba entre el tercer i quart parell de potes 


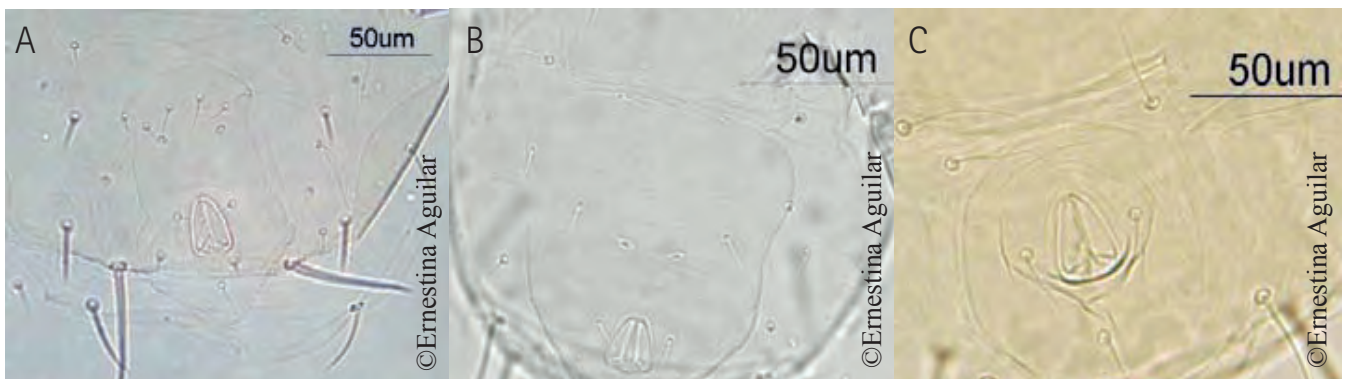

Figura 25. Placa ventrianal d'Euseius stipulatus (A); Neoseiulus californicus (B) i Phytoseiulus persimilis (C)

Les espècies més importants que podem trobar en la Comunitat Valenciana són Phytoseiulus persimilis, espècie autòctona de color roig característic i depredador molt actiu especialitzat en àcars del gènere Tetranychus i en concret de T. urticae (McMurtry i Croft, 1997); Neoseiulus californicus (McGregor), igualment autòcton i més estès en tot tipus de plantes cultivades i espontànies, especialitzat també en àcars tetraníquids $\mathrm{i}$ bon depredador de nombroses espècies plaga com ara $P$. citri, P. ulmi, T. urticae, Tetranychus turkestani Ugarov i Nikolski i Tetranychus ludeni Zacher (Abad-Moyano et al., 2009a); i Euseius stipulatus (Athias-Henriot), depredador generalista especialitzat en pol·len (McMurtry i Croft, 1997) i el més abundant en els cítrics peninsulars, on la seua presència és clau per mantenir sota el llindar econòmic a P. citri (Ferragut et al., 1988; Abad-Moyano et al., 2009b) (figura 26), fet que constitueix un exemple molt exitós de control biològic fortuit, ja que E. stipulatus és autòcton, mentre que $P$. citri és una espècie introduïda als anys 1980 .

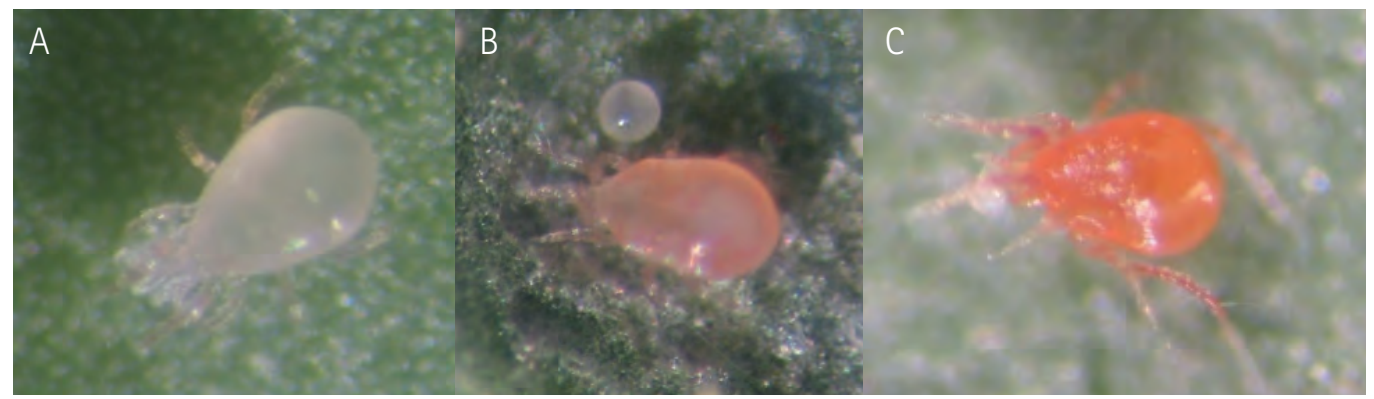

Figura 26. Fitoseids adults d'Euseius stipulatus (A); Neoseiulus californicus (B) i Phytoseiulus persimilis $(\mathrm{C})$

Hi ha altres espècies de fitoseids importants a la nostra zona com Amblyseius andersoni (Chant) i Kampimodromus aberrans Oudemans, ambdós generalistes i clau per al control de P. ulmi en fruiters de grana o Neoseiulus cucumeris (Oudemans) i Amblyseius swirskii (espècie exòtica) sobre trips, mosca blanca i aranya blanca, entre d'altres.

Els laelàpids (família Laelapidae) inclouen des d'espècies paràsites de les abelles mel-leres (p. ex. Tropilaelaps clareae Delfinado i Baker), que causen grans pèrdues en els ruscs asiàtics (Sammataro et al., 2000), fins a espècies emprades en el control 
biològic d'espècies plaga, com ara Stratiolaelaps (=Hypoaspis) miles (Berlese), que s'empra comercialment per al control de mosques sciàrides, o Geolaelaps (=Hypoaspis) aculeifer (Canestrini), utilitzat també comercialment com a enemic natural de nematodes, colllèmbols, trips i acarídids (Gerson et al., 2003). Es tracta d'àcars de gran mida que es caracteritzen pel fet de presentar una placa dorsal amb més de 23 parells de sedes (figura 27).

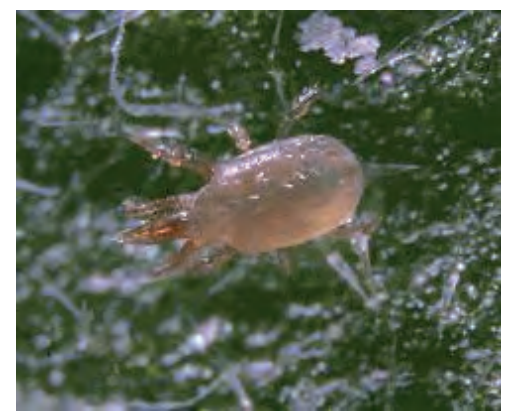

Figura 27. Adult del laelàpid Stratiolaelaps miles, espècie comercialitzada per al control d'algunes espècies plaga

La família Varroidae es caracteritza pel fet de presentar un aspecte de cranc de mar i mides d'1,1 a 1,6 mm (figura 28). Destaquen les espècies Varroa destructor Anderson i Trueman i Varroa jacobsoni (Oudemans). Aquestes espècies estan considerades com la major plaga de les abelles mel·leres pràcticament a tot el món. Les abelles afectades manifesten símptomes molt característics (varroasi), com ara el canvi de color de les pupes o la deformació de les potes i les ales en els adults, entre altres afeccions (Sammataro et al., 2000).

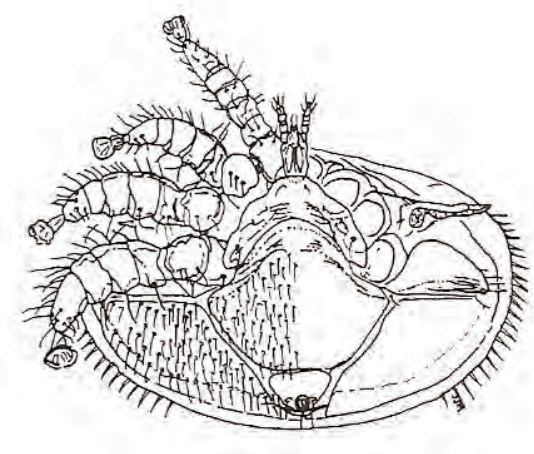

Figura 28. Dibuix d'un adult de la família Varroidae 


\subsection{Clau simplificada dels principals ordres i superordres d'àcars}

La clau que proposem a continuació és una clau modificada d'Iturrondobeitia (2004) que ens permet arribar fins a la categoria de subordre.

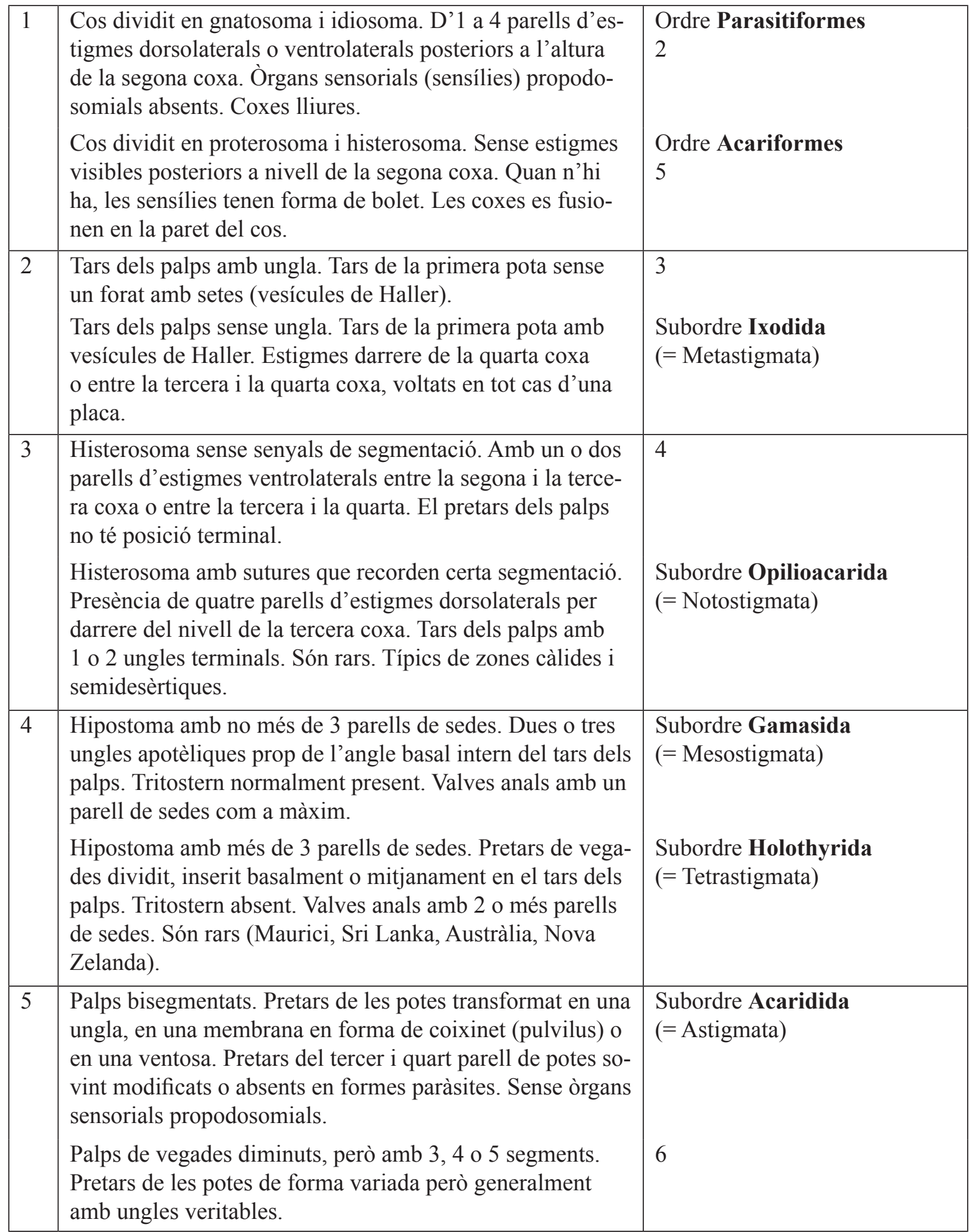




\begin{tabular}{|l|l|l|}
\hline 6 & $\begin{array}{l}\text { Quelícers estiletiformes, com si foren ganxos, rara vegada } \\
\text { quelats. Els estigmes s'obrin en la base dels quelícers, en } \\
\text { la base del gnatosoma o en els angles humerals del propo- } \\
\text { dosoma. Pretars de les potes de diverses formes: ungles, } \\
\text { pintes, coixinets, ventoses. Esclerotització dèbil. }\end{array}$ & $\begin{array}{l}\text { Subordre Actinedida } \\
\text { (= Prostigmata) }\end{array}$ \\
$\begin{array}{l}\text { Quelícers quelats i dentats. Estigmes damunt de cavitats } \\
\text { acetabulars que es troben ocultes en la base de les potes } \\
\text { o damunt d'aquestes o en el botridi. Sensílies botridials } \\
\text { presents en un parell de potes. Pretarsos transformats en } \\
\text { ungles. La majoria estan ben esclerotitzats i durs. }\end{array}$ & $\begin{array}{l}\text { Subordre Oribatida } \\
\text { (= Cryptostigmata) }\end{array}$ \\
\hline
\end{tabular}

\subsection{Vocabulari}

Per facilitar el seguiment de la pràctica proposada us facilitem un breu vocabulari.

Apotele: és el pretars o ambulacre. Es pot presentar en forma d'ungles, dits mòbils, punxes, ventoses.

Botridi: estructura en forma de copa on naixen les sensílies.

Coxa: segment basal de la pota que pot estar articulat en els Parasitiformes o fusionat a la paret del cos en els Acariformes.

Deutonimfa: també coneguda com a deuteronimfa. És el segon estadi nimfal.

Edeagus: penis o un altre òrgan masculí que serveix per transferir l'esperma als conductes femenins durant la còpula.

Espermateca: estructura en forma de sac que permet a la femella emmagatzemar l'esperma. És un caràcter taxonòmic molt important en els fitoseids.

Espermatodàctil: òrgan en forma d'agulla o dit emprat per transferir el paquet espermàtic fins a l'orifici genital de la femella. Es troba en els quelícers d'alguns Mesostigmata. Té una forma molt variable, des de molt simple, en forma de dit, fins a una estructura allargada i doblegada.

Estigmes: obertura del sistema traqueal.

Estilet: estructura estreta i apuntada que es refereix típicament en les peces bucals dels àcars.

Gnatosoma: part més anterior de l'àcar formada pels quelícers i els pedipalps i separada de la resta del cos (idiosoma) per un anell de cutícula molt dèbil.

Hipostoma: part anterior ventral dels àcars formada per les coxes dels palps, part inferior del gnatosoma i altres elements.

Histerosoma: regió del cos que va des de la segona i tercera pota fins al final del cos. Oposat al proterosoma.

Idiosoma: principal part del cos, que conté l'opistosoma i part del prosoma.

Metapodosoma: regió del cos on s'inclouen el tercer i quart parell de potes.

Opistosoma: part posterior del cos dels aràcnids. Normalment no es diferencia en els àcars, ja que es fusiona amb part del prosoma per formar l'idiosoma.

Palp: segon parell d'apèndixs dels aràcnids emprat per alimentar-se i que apareixen al costat dels quelícers. Poden des de ser vestigials fins a tindre com a màxim cinc segments articulats $\mathrm{i}$ un apotele distal o subdistal. 
Pedipalp: és equivalent al palp.

Peritrema: solc més o menys llarg que actua com a càmera prestigmàtica i que en alguns àcars aquàtics és necessari per a l'intercanvi gasós. Connecta amb l'obertura estigmàtica.

Placa ventrianal: placa ventral que apareix en els mesostigmata i que inclou l'obertura anal, les sedes al voltant de l'anus i una o més parelles de sedes ventrals o pors. Pot ser des d'estreta fins a molt ampla, cobrint pràcticament tota la regió ventral.

Podosoma: regió de l'idiosoma on estan les potes.

Propodosoma: subdivisió del podosoma on s'inclou el primer parell de potes.

Prosoma: part anterior del cos on s'inclouen les potes. La regió oposada és l'opistosoma.

Proterosoma: part anterior del cos fins al plec sejugal. Oposat a l'histerosoma.

Protonimfa: primer estadi nimfal.

Pulvilus: estructura membranosa, semblant a un coixinet, que apareix en el pretars dels Mesostigmata i dels Astigmata.

Quelicers: primer parell d'apèndixs del cos dels quelicerats. Ocupen una posició anterior a la boca $\mathrm{i}$ es caracteritzen perquè es diferencien com òrgans prensors en forma de pinça o en forma de ganxo.

Sensílies: estructura sensorial.

Tars: segment de la pota que es troba entre la tíbia i el pretars.

Tricobòtries: sedes sensorials de gran valor taxonòmic que naixen en el botridi. Poden trobar-se en qualsevol regió del cos o de les potes.

Tritonimfa: tercer estadi nimfal que apareix en els Opilioacarida, Holothyrida, Argasidae i molts Acariformes.

Trocànter: segment de la pota entre la coxa i el fèmur.

Tritostern: estructura ventral en forma de «V» que naix en l'idiosoma i envaeix el gnatosoma, i que té un paper en la ingestió de fluids.

Vesícules o òrgan de Haller: agrupacions de setes que formen camps sensitius, situades en una depressió del tars al primer parell de potes, fonamentalment dels ixòdids (caparres).

\section{Objectius de la pràctica}

Els objectius d'aquesta pràctica es concreten en quatre:

1. Reconèixer els principals subordres d'àcars.

2. Familiaritzar-se amb la morfologia d'aquest grup: aspecte dels quelícers, disposició de les sedes, espermateques, plaques ventrianals, estigmes, etc.

3. Conèixer com es realitza una preparació microscòpica dels àcars.

4. Aprendre a utilitzar el microscopi com a ferramenta de diagnòstic. 


\section{Desenvolupament de la pràctica}

\subsection{Material}

El material necessari per dur a terme aquesta pràctica és:

- Col·lecció d'àcars de la col·lecció del grup de Gestió Integrada de Plagues de la Universitat Jaume I

- Cries d'àcars disponibles en el moment de la pràctica com ara el tetraníquid Tetranychus urticae i el fitoseid Euseius stipulatus

- Lupa binocular

- Pinzell

- Comptagotes

- Àcid làctic

- Encenedor

- Portaobjectes

- Cobreobjectes

- Microscopi

- Clau taxonòmica proporcionada

\subsection{Metodologia}

En funció del material de què disposem procedirem d'una manera o d'una altra. Si el material encara és viu, col-locarem una gota d'àcid làctic en el portaobjectes. Amb la punta d'un pinzell lleugerament humit, i sota la lupa binocular, agafarem l'àcar viu i el colllocarem al mig de la gota. Si és un fitoseid el posarem ventralment o dorsalment amb les potes esteses, mentre que si es tracta d'un tetraníquid, triarem els mascles i els muntarem de costat per poder observar la morfologia de l'edeagus. A continuació col·locarem suaument el cobreobjectes damunt de la gota tenint la precaució que no es formen bombolles d'aire en l'interior, i que no escape l'àcar amb el líquid. Amb molta cura de no cremar-nos, i sempre lluny de la cara, escalfarem el portaobjectes per la cara inferior amb l'ajuda d'un encenedor evitant que el líquid arribe a bullir, ja que podria botar el cobreobjectes i perdre's el muntatge. El que es pretén amb aquesta calor és digerir els teixits interns de l'àcar respectant-ne la cutícula, que no s'ha de trencar, ja que és en aquesta on es troben els principals caràcters emprats en la identificació de les espècies. Aquesta manera de preparar els àcars és el que es diu un muntatge ràpid, i serveix per a una observació immediata de la mostra. Per conservar-la més enllà de tres o quatre dies, caldria digerir l'àcar lentament en àcid làctic i després muntar-lo en un medi semipermanent com el líquid de Hoyer.

Arribat a aquest punt procedirem de la mateixa manera tant si la mostra estava viva com si estava ja muntada. Col·locarem la preparació en el microscopi i, començant per l'objectiu més menut, buscarem l'àcar. Una vegada localitzat, anirem augmentant progressivament els augments fins que en veiem les estructures que s'esmenten a la clau. Jugarem amb l'enfocament (micròmetre) per observar la cara dorsal o ventral de l'àcar pujant o baixant molt lentament la preparació per no trencar-la.

Finalment, i amb l'ajut de la clau proporcionada, caldrà que determinem els ordres i subordres dels àcars proporcionats. 


\section{PRÀCTICA 4 \\ Observació i identificació d'alguns fongs d'importància agronòmica}

\section{Antecedents}

\subsection{Els fongs}

Els fongs, considerats fins no fa molt de temps com un grup diferenciat, englobat dins del regne vegetal, actualment es consideren un regne a part, el Regne Fungi, caracteritzat pel fet d'estar format per organismes sense clorofil-la (per tant, heteròtrofs), constituïts per cèl-lules eucariotes que formen un aparell vegetatiu molt simple, que anomenem tal·lus.

Donat que els fongs són incapaços d'emprar el diòxid de carboni per sintetitzar matèria orgànica, o bé cobreixen les seues necessitats a partir de matèria orgànica morta (fongs sapròfits) o bé a partir d'éssers vius (fongs paràsits). En alguns casos poden utilitzar ambdues fonts i parlarem de fongs paràsits facultatius. Un cas especial el constitueixen les espècies simbiòtiques, associades ja siga amb algues (líquens) o amb vegetals superiors (micorrizes), que els proporcionen els hidrats de carboni que els calen.

Els fongs paràsits són els que més ens interessen en protecció vegetal. La interacció d'aquests fongs fitopatògens amb els seus hostes produiran les malalties criptogàmiques, amb una simptomatologia típica que, en molts casos, permet la identificació de l'agent causal (míldius, càries, carbons, rovells, antracnosis, etc.). En altres casos, els símptomes són inespecífics (xancres, marciments, tumors, podridures, marciments progressius, etc.) i, per tant, caldrà fer un diagnòstic al laboratori per poder-ne saber la causa.

També dins dels fongs trobem grups que tenen interès des del punt de vista del control biològic d'insectes (fongs entomopatògens), de males herbes (els anomenats micoherbicides) o, fins i tot, d'altres fongs (lluita biològica per competència). Entre els entomopatògens, destaca l'ordre Entomophtorales dins de la classe Zygomycetes, així com algun gènere aïllat, com Lecanicillium, que presenta alguna espècie entomopatògena (L. lecanii (Zimmermann)). En la lluita biològica per competència, a més d'espècies no patògenes, tenen prou interès les micorrizes, que poden proporcionar també altres avantatges per a la nutrició de la planta hoste. 


\subsection{Els fongs fitopatògens}

Les malalties de les plantes que denominem d'origen criptogàmic estan causades per agents que es troben repartits entre tres regnes diferents:

1. En el Regne Protozoa, hi trobem els Mixomycota, com l'agent causal de l'hèrnia de la col (Plasmodiophora brassicae Woronin) (figura 1).

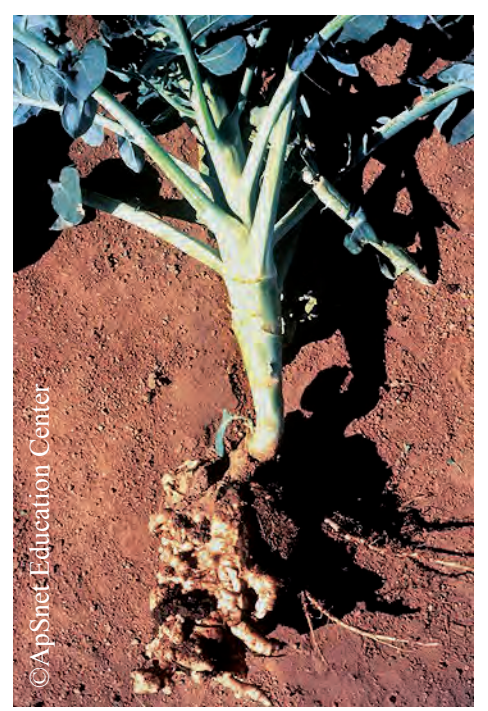

Figura 1. Hèrnia de la col. Malaltia causada per Plasmodiophora brassicae, que provoca bonys irregulars a les arrels $i$ al coll de les crucíferes

2. En el Regne Chromista trobem els Oomycota, on s'engloben tots els míldius coneguts (gèneres com Phytophthora, Plasmopara, Bremia, etc.) (figura 2).

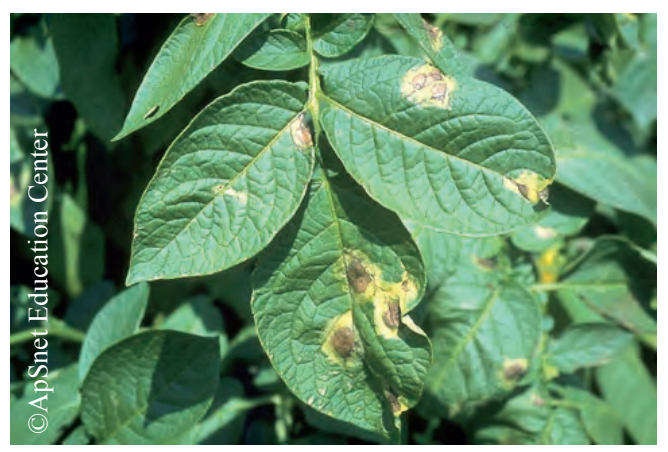

Figura 2. Lesions de míldiu, provocades per Phytophthora infestans, en fulla de creïlla

3. Finalment, en el Regne Fungi, hi trobem els fongs veritables (també coneguts com a Eumycota), amb grups molt importants com els Ascomycota, que inclouen els oïdis (gèneres com Erysiphe, Sphaeroteca, Uncinula, etc.) (figura 3), així com els fongs popularment coneguts com a imperfectes o deuteromicets (gèneres importants com Botrytis, Verticillium, Fusarium, etc.), i els Basidiomycota, amb grups importants com els rovells (gèneres Puccinia, Phragmidium, etc.) o els 
carbons i les càries (gèneres Ustilago i Tilletia), a més de la majoria dels bolets comestibles que es coneixen (com els xampinyons, Agaricus spp., o l'esclatasang, Lactarius sanguifluus (Paulet)) (figura 4).

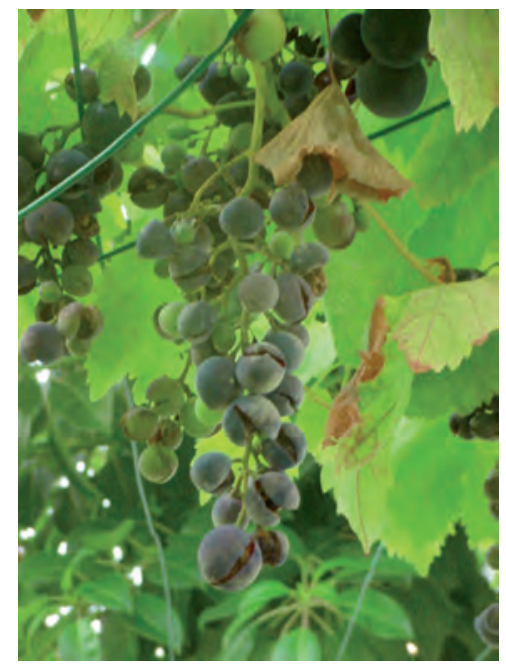

Figura 3. Raïm amb els grans badats a causa de l'atac de l'ascomicet, Uncinula necator (Schwein) Burrill, que provoca l'oïdi de la vinya. Oidium tuckeri Berk. n'és la forma anamòrfica

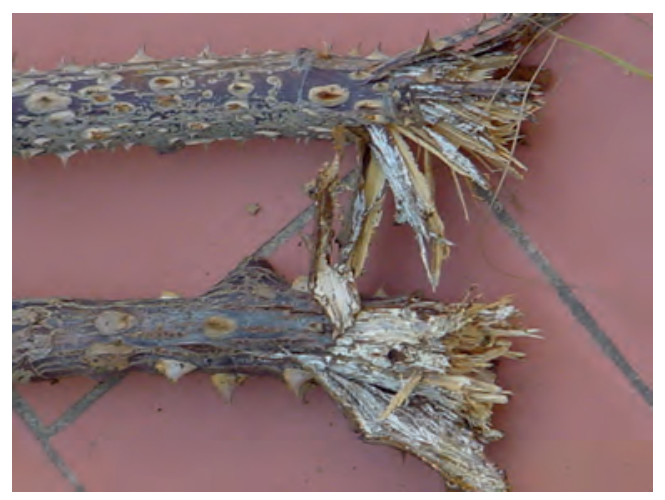

Figura 4. Podridura de les arrels causada pel basidiomicet Armillaria mellea (Vahl). A la zona del coll d'aquest roser s'observa la podridura blanca típica d'aquest fong, que provoca danys greus en fruiters i en vinya

Tots els fongs es poden multiplicar vegetativament, mitjançant un fragment de miceli. Els fongs que només es poden reproduir així s'anomenen fongs estèrils. La majoria de fongs, però, també es poden reproduir asexualment, diferenciant en el miceli una estructura, el conidiòfor, que conté els conidis o espores mitospòriques, ja que en la seua gènesi no ha tingut lloc cap fenomen de tipus sexual. Del fong que es reproduiex així, en diem anamorf, i d'aquest estat se'n diu anamòrfic. No obstant això, molts fongs també es poden reproduir sexualment, després d'un intercanvi de material genètic $i$ un procés de meiosi. En aquest cas, parlem de fongs teleomorfs, i d'aquest estat en diem teleomòrfic. Els teleomorfs es reprodueixen mitjançant estructures específiques i de les espores que produeixen en diem meiòtiques per diferenciar-les de les dels anamorfs. 
Un mateix fong pot presentar-se en forma anamòrfica i teleomòrfica (que en conjunt s'anomena holomorf), encara que sovint ambdues formes apareixen separades en el temps o en l'espai. No obstant això, no sempre una forma anamòrfica es correspon a un teleomorf determinat i viceversa. Per aquesta raó, molts fongs reben dues denominacions, segons quin siga l'estat en què es troba. Així, diem que el fong causant de l'oïdi de la vinya és l'ascomicet Uncinula necator (teleomorf), que es multiplica sexualment mitjançant espores meiòtiques anomenades ascòspores, i el seu anamorf, Oidium tuckeri, ho fa mitjançant conidis o espores mitòtiques (figura 3).

Durant la major part del seu cicle, els fongs presenten nuclis haploides. Només aquells que es multipliquen sexualment passen a ser diploides durant un breu espai de temps, suficient perquè es produïsca la cariogàmia, seguida d'una meiosi que originarà les espores sexuals, que anomenem zoòspores en els oomicets, basidiòspores en els basidiomicets i ascòspores en els ascomicets (figura 5).

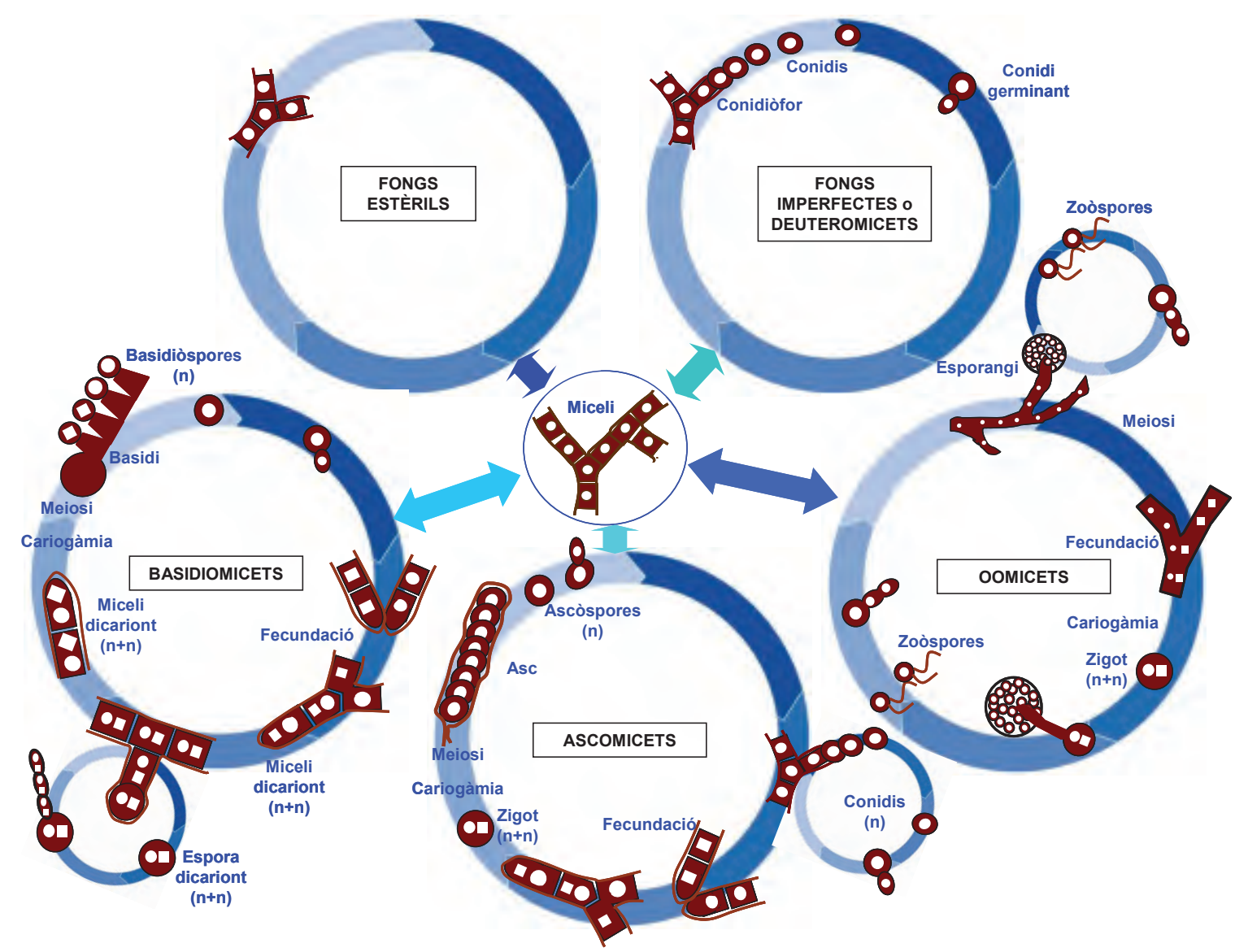

Figura 5. Esquema dels cicles vitals dels principals grups de fongs fitopatògens (adaptat d'Agrios, 1997). Com es pot veure clarament en l'esquema, el cicle dels fongs imperfectes es correspon exactament amb la fase de reproducció asexual dels ascomicets

La taxonomia de tots aquests grups d'agents fitopatògens no és senzilla, i pot canviar segons l'autor que se seguisca. A més, amb els nous avenços en el camp de la biologia molecular, hi ha hagut canvis importants en la classificació tradicional 
dels fongs (per exemple, els deuteromicets, considerats tradicionalment una divisió a part, han passat a ser considerats una classe dins dels Ascomycota). Malgrat tot, la identificació rutinària al laboratori continua basant-se en l'observació de les estructures de reproducció (sexuals o asexuals), que farem aparèixer fent fructificar el fong en la càmera humida.

\subsection{Signes i símptomes}

Els fongs fitopatògens, com tots els patògens en general, es caracteritzen pels signes i els símptomes que originen en el seu hoste.

Un signe és allò que fa visible la presència del patogen al vegetal afectat, com pot ser l'aparició d'una fructificació del fong, algunes tan evidents com, per exemple, un bolet. Altres signes que podem trobar són:

- Masses de miceli, que són les que componen el cos vegetatiu dels fongs

- Exsudats, com poden ser els de goma que solen aparèixer en espècies llenyoses

- Rizomorfs o cordons hifals típics, per exemple, de la podridura blanca (figura 4)

- Clistotecis o altres fructificacions, que apareixen en forma de puntets sobre la superfície afectada.

D'altra banda, un símptoma és l'expressió d'un canvi en la morfologia o la fisiologia de la planta afectada, com per exemple:

- Marciments de tiges

- Mort de brots, flors, fulles

- Aparició de necrosis més o menys generalitzades

- Aparició d'agalles o tumoracions

- Floridures o podridures

- Aparició de taques

- Aparició de proliferacions de tiges en forma de granera de bruixa.

La manifestació del símptoma dependrà de l'espècie i cultivar de la planta, del patogen i de l'ambient.

Sovint, els signes i símptomes (que en conjunt defineixen el que anomenem una síndrome) que podem observar permeten diagnosticar una malaltia d'origen fúngic de visu. Aquest és el cas dels oïdis, els míldius, els rovells, els carbons i les fumagines. L'observació al microscopi de les seues espores ens permetrà identificar el gènere i l'espècie de què es tracte. 


\subsection{Diagnòstic. La càmera humida}

La majoria dels fongs, per fructificar (produir espores), solen tenir-ne prou amb unes condicions d'humitat i temperatura altes. Per aquesta raó, el diagnòstic rutinari de les malalties criptogàmiques sol començar sotmetent la mostra sospitosa a humitat de saturació i una temperatura entre els $20^{\circ} \mathrm{C}$ i els $25^{\circ} \mathrm{C}$. Açò ho aconseguim mitjançant l'anomenada càmera humida.

La càmera humida consisteix en un recipient tancat, generalment de vidre, l'interior del qual va revestit de paper de filtre. Aquest paper es banya totalment amb aigua destillada, de manera que quan tanquem el recipient, l'interior queda totalment saturat d'humitat. Si col-loquem aquesta càmera a temperatura de laboratori $\left(20^{\circ} \mathrm{C}-25^{\circ} \mathrm{C}\right)$, la majoria de fongs fructifiquen en poc més de 24 hores. Només en alguns casos cal manipular les condicions de forma especial, per exemple amb llum ultraviolada, provocant un salt tèrmic o afegint algun component especial al substrat, per tal d'afavorir l'esporulació. Aquest fenomen sol ocórrer amb la majoria dels fongs imperfectes o deuteromicets, que, en condicions estàndard, no presenten reproducció de tipus sexual. A voltes, ni sotmetent-los a aquestes condicions s'ha aconseguit que aquest grup de fongs es reproduïsca sexualment, i és per això que se'ls qualifica vulgarment d'imperfectes.

Una volta que el fong ha esporulat, caldrà fer-ne una preparació microscòpica (en portaobjectes), convenientment tenyida. Observant la preparació, primerament a la lupa i després al microscopi òptic, i seguint les claus corresponents, es farà la identificació del fong que causa els símptomes observats en la planta o òrgan vegetal afectat. Açò és el que es farà en aquesta pràctica.

\subsection{Característiques de les principals divisions}

\subsubsection{Divisió Oomycota: els míldius}

Els míldius no són fongs veritables (Eumycota), sinó organismes afins, que s'engloben en el regne dels Chromista, ja que no posseeixen quitina (component típic dels eumicots) i presenten espores flagel·lades o zoòspores. Malgrat la diferent filiació, donat que es tracta d'organismes molt semblants en el seu funcionament al dels fongs, solen estudiar-se junts.

Els míldius es caracteritzen perquè els seus atacs solen començar en les fulles, on apareixen taques (sovint limitades per les mateixes nerviacions foliars) d'aspecte oliós, descolorides i que van creixent. En donar-se les condicions adequades d'humitat i temperatura, aquestes taques comencen a produir esporangiòfors, que donen a la part afectada un aspecte avellutat blanc o més o menys brut. De míldius en trobem en dues famílies: les pitiàcies (gènere Phytophthora) i les perenosporàcies (gèneres Bremia, Plasmopara i Perenospora). 
El gènere Phytophthora comprèn espècies que provoquen dos tipus de malaltia: les que viuen al sòl i ataquen arrels o la zona del coll provocant marciments en la part aèria; i les que viuen en la part aèria i provoquen els míldius típics. Així, P. cactorum (Lebert i Cohn) provoca tant el míldiu de la maduixera (fulles marcides, maduixes que s'assequen prematurament i es floreixen) com la tinta del castanyer i de la noguera (l'arbre s'asseca i mor: a la base apareixen lesions per on s'escola un líquid fosc). Phytophthora cambivora (Petri) Buisman i P. cinnamomi Rands també apareixen associades al castanyer i a la noguera. Phytophthora capsici Leonian és l'agent causal dels marciments progressius en albergínia i pebrotera. Phytophthora parasitica Dastur provoca podriment de la zona del coll, gomosi i l'aigualit dels cítrics, així com marciments progressius en tomaquera. Phytophthora citrophthora (R. E. Smith i E. H. Smith) Leonian i P. palmivora (Butler) també apareixen associats als cítrics. Entre els míldius purament aeris, destaca P. infestans (Mont.) de Bary (míldiu de la creïlla i de la tomaquera) i P. porri Foister (míldiu del porro). Phytophthora infestans va arribar a Europa al segle XIX i provocà, sobretot a l'illa d'Irlanda, greus problemes de fam. Es manifesta en la creïlla per l'aparició de taques marronoses a les fulles, que s'assequen ràpidament $i$ que, quan les condicions de temperatura i humitat són adequades, presenten a la cara inferior l'aspecte vellutat blanc típic. La malaltia sol aparèixer en focus, però en donar-se les condicions adequades (tempestes estivals), s'escampa ràpidament, $\mathrm{i}$ arriba a destruir el cultiu en pocs dies. Els tubercles d'aquestes plantes, una volta recol-lectats, presenten taques marronoses difuminades en superfície, que es corresponen amb zones de la carn de color de rovell i aspecte de marbre, fibroses o granuloses. Aquests tubercles es podreixen i perden tot el valor comercial (figura 6). En tomaquera, els atacs apareixen tant en fulla com en fruita.
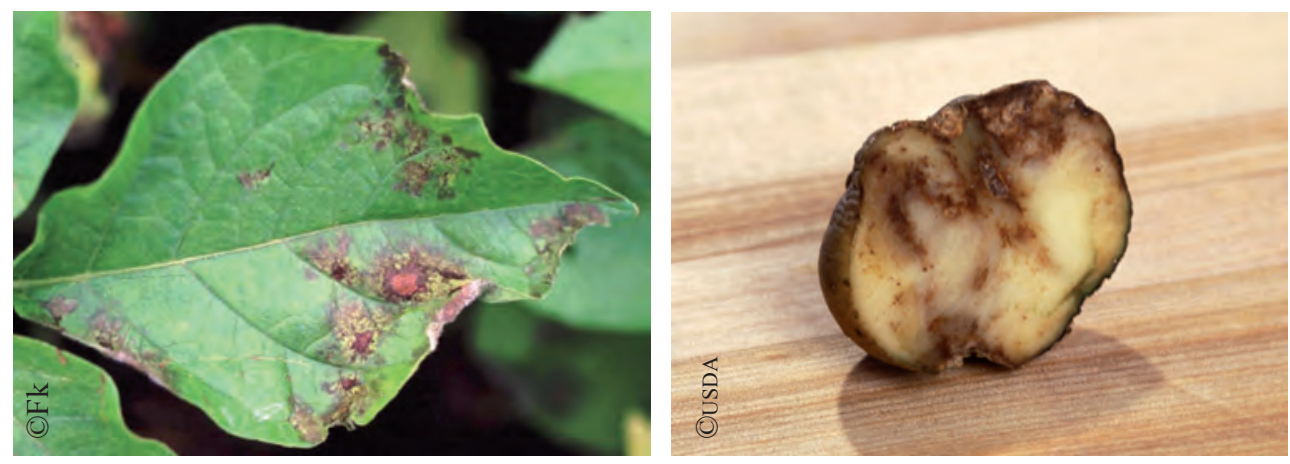

Figura 6. Danys de Phytophthora infestans en fulla (esquerra) i tubercle (dreta)

Plasmopara viticola (Berk. i Curtis) és l'agent causal del míldiu de la vinya (figura 7). Aquesta malaltia important (arribada també des d'Amèrica el segle XIX) es manifesta tant en vergues com en fulles i raïms. Les vergues afectades no lignifiquen bé, queden curtes i gruixudes, solen torçar-se en forma d'essa i, si hi ha una humitat elevada, apareix un florit blanquinós. A la cara superior de les fulles apareixen taques olioses, de color groguenc a les varietats blanques, i roig vinós a les negres. En aquest cas, també apareix el florit blanquinós a la cara inferior de les fulles si la humitat és alta, florit que tornem a trobar sobre inflorescències i raïm atacats. Dins del gènere Plasmopara, trobem altres espècies importants, com $P$. nivea 
(Unger) J. Schröt, que provoca el míldiu de les umbel·líferes, o P. halstedi (Farl.) Berl. i de Toni, que causa el míldiu del gira-sol. Altres míldius importants són el del tabac (Peronospora tabacina Adam), el de les crucíferes (P. brassicae Gäum.), el de la ceba ( $P$. schleideni Unger) i el de la remolatxa ( $P$. schachtii Fuckel). El míldiu de les compostes està causat per Bremia lactucae Regel, molt important en encisam.
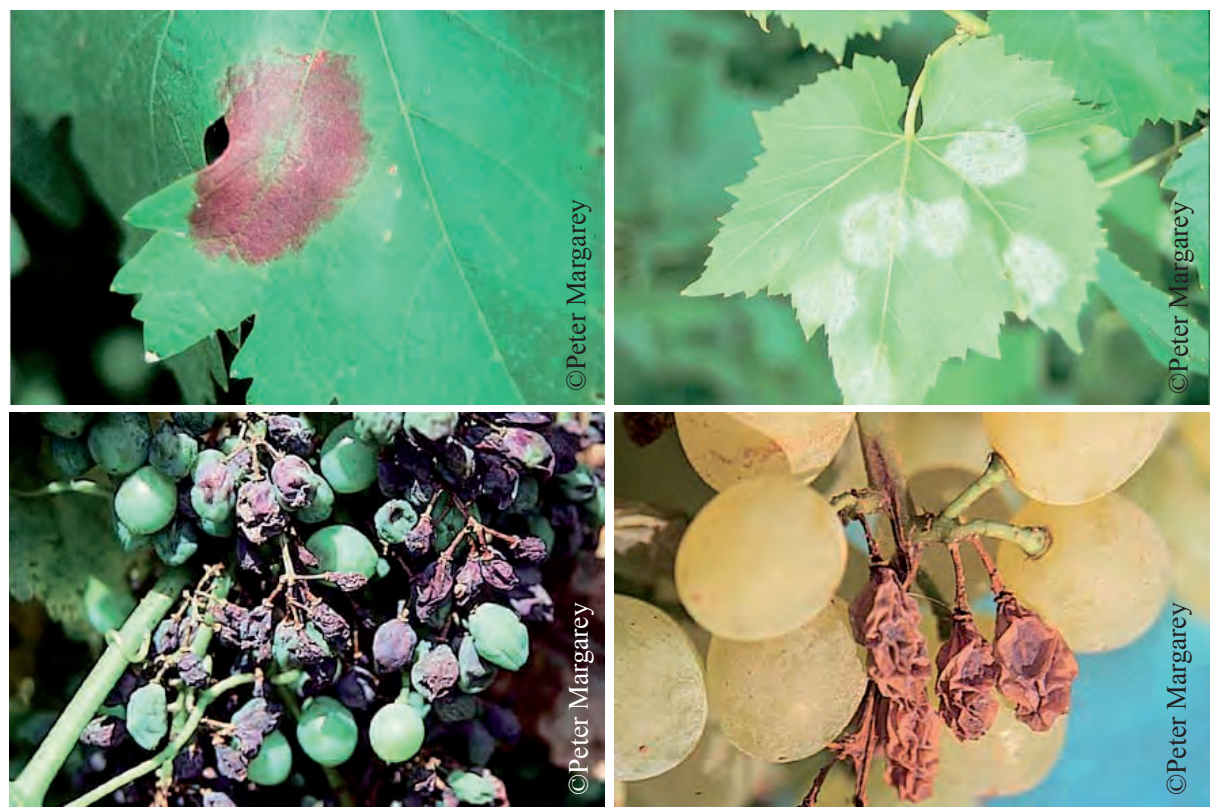

Figura 7. Danys de Plasmopora viticola en fulla (dalt) i fruit (baix)

\subsubsection{Divisió Basidiomycota: els rovells i els carbons}

\section{Els rovells}

En aquest cas ens trobem amb malalties produïdes per fongs paràsits estrictes, que no són capaços d'alimentar-se de matèria orgànica morta i que, per tant, difícilment serem capaços de cultivar en medi de cultiu pur. Els fongs que provoquen els rovells pertanyen al grup dels basidiomicets uredinals.

Els rovells, al llarg del cicle vital, poden arribar a produir fins a cinc tipus diferents d'espores en pústules o sorus especials:

- Espermàcies: petites, globoses, hialines, sovint embolcallades amb una substància ensucrada $i$ apegalosa que atrau els insectes. Les trobem agrupades formant una una mena de picnidi, que anomenem espermogoni.

- Eciòspores: irregularment globoses, poc pigmentades, lleugerament espinoses, sovint acompanyades per cèl-lules peridials. Les trobem agrupades en ecis. El fong en aquest estadi sol produir auxines $i$ altres reguladors del creixement que provoquen deformacions prou visibles en els òrgans atacats de la planta hoste.

- Urediniòspores: globoses, unicel·lulars, de paret finament espinosa i de color groguenc. Són espores de multiplicació, que transmeten el paràsit d'una part a 
una altra del vegetal. S'agrupen formant uredinis o urediniosorus, i les veiem a la superfície del vegetal com pústules que esclaten.

- Teliòspores: són espores que serveixen per conservar l'individu d'un any per a l'altre. Apareixen en telis, o teliosorus, i poden aparèixer soles o mesclades amb urediniòspores. N'hi ha d'unicel-lulars (gènere Uromyces), de bicel·lulars (gènere Puccinia) i de pluricel·lulars (gènere Phragmidium).

- Basidiòspores: són molt menudes i fràgils. Es pot veure com s'han format en germinar les teliòspores.

Totes aquestes espores presenten diferents colors, segons l'espècie de què es tracte, també segons el tipus d'espora; però totes tenen tonalitats entre grogues i marronoses, per això el nom d'aquestes malalties, ja que el vegetal afectat pareix que estiga rovellat.

No tots els rovells produeixen els cinc tipus d'espora. N'hi ha que només produeixen teliòspores $\mathrm{i}$ basidiòspores, $\mathrm{i}$ són els que anomenem de cicle curt o microcíclics. La resta de rovells solen produir tots els tipus d'espora esmentats, i els coneixem com a macrocíclics o de cicle llarg. Hi ha casos, però, on manquen les espermàcies i/o les urediniòspores.

Entre els rovells macrocíclics, n'hi ha que completen el seu cicle sobre un sol hoste (p. ex. el rovell de l'espàrrec, Puccinia asparagi DC., o el de la fasolera, Uromyces appendiculatus (Pers.) Link), i per això els anomenem autoics (o monòxenes). Per contra, n'hi ha d'altres que necessiten dos hostes diferents per completar-lo, i que anomenem heteroics (o heteròxenes). Aquest és el cas, per exemple, del rovell de les pereres, Gymnosporangium sabinae (Dicks.) G. Winter. Les basidiòspores d'aquest rovell infecten les fulles de la perera, on produeixen espermogonis i, posteriorment, ecis, però les eciòspores no són capaces d'infectar novament la perera, sinó que els cal germinar en fulla de sabina (Juniperus sabinae L.), on produiran urediniòspores $\mathrm{i}$, finalment, la primavera següent teliòspores, que donaran origen als basidis, que ja podran reinfectar pereres dels voltants. Puccinia graminis Pers., l'agent causal del rovell dels cereals, també és heteroic. En aquest cas, l'hoste ècic és el coralet (Berberis vulgaris (L.)), mentre que els uredinis i els telis apareixeran sobre les gramínies.

Els agents causals dels rovells es distribueixen en tres famílies importants: la dels pucciniacis, la més important de totes tres, caracteritzada pel fet de presentar teliòspores pedicel-lades i separades les unes de les altres (gèneres Coleosporium, Gymnosporangium, Phragmidium, Puccinia, Tranzschela i Uromyces; la dels cronartiacis, amb teliòspores sèssils que s'agrupen formant una mena de columnetes (gènere Cronatium), i la dels melampsoracis, amb teliòspores també sèssils però molt atapeïdes en sorus foscos (gènere Melampsora).

Coleosporium spp. provoca el rovell de les acícules del pi, que n'és el seu hoste ècic, mentre que la resta d'espores es formen en compostes, com Sonchus spp. o Senecio spp. 
El gènere Phragmidium es troba associat a les rosàcies, i està compost únicament per espècies autoiques. Phragmidium subcorticium (Schrank) G. Winter és l'agent causal del rovell del roser. N'és característica la presència de pústules de color taronja (urediniòspores) o marrons (teliòspores) en la cara inferior de les fulles, que es corresponen amb taques de color groc a la cara superior. La forma ecidiana d'aquest fong es produeix a les tiges $i$ als peduncles florals. Anàlogament, $P$. rubi-idaei (DC.) P. Karst. provoca el rovell de la gerdera, i P. violaceum (Schultz) G. Winter, el de l'esbarzer.

Puccinia asparagi causa el rovell de l'espàrrec i de la ceba (autoic i macrocíclic), P. cichorii (DC.) Bellynck, el de la xicòria, P. coronata Corda, el rovell coronat de l'ordi (heteroica i macrocíclica: forma ècica sobre Rhamnus cathartica L. i Frangula alnus Miller), P. graminis, el rovell negre dels cereals (heteroic i macrocíclic: forma ècica sobre el coralet), $P$. hordei Otth, el rovell nan de l'ordi (heteroic i macrocíclic: ecis sobre Ornithogalum spp.), P. glumarum Schmidt, el rovell groc dels cereals, $P$. menthae Pers, el rovell de la menta (autoic i macrocíclic), $P$. pelargonii-zonalis Doidge, el rovell dels geranis cultivats (autoic i macrocíclic), P. porri (Sowerby) G. Winter, el rovell del porro i de l'all (autoic i macrocíclic) (figura 8), P. sorghi Schwein., el rovell del panís (heteroic i macrocíclic: ecis sobre Oxalis spp.), i P. triticina, el rovell marró del blat (heteroic i macrocíclic: ecis sobre Thalictrum spp.).

Tranzschelia pruni-spinosae (Pers.) Dietel és l'agent causal del rovell de la prunera (heteroica i macrocíclica: ecis sobre Anemone coronaria L.). Uromyces appendiculatus (Pers.) Link. és responsable del rovell de la fesolera (autoic i macrocíclic); U. betae (Pers.) J. C. Kühn, del de la remolatxa (autoic i macrocíclic); U. pisi (Pers.) de Bary, del del pèsol (heteroic i macrocíclic: ecis sobre Euphorbia cyparissias L.) i U. striatus Schröt, el de l'alfals (heteroic i macrocíclic: forma ècica també sobre E. cyparissias). Cronartium ribicola Dietr., provoca un rovell a l'escorça del pi (fase ècica), mentre que la resta del cicle la passa sobre el groseller.

Per acabar, Melampsora lini (Ehrenb.) Lév. i M. pinitorqua Rostr., són els agents causals dels rovells del lli i del rovell corbat del pi, respectivament. En l'últim cas, l'hoste ècic del rovell són determinades espècies de pollancre americà. 

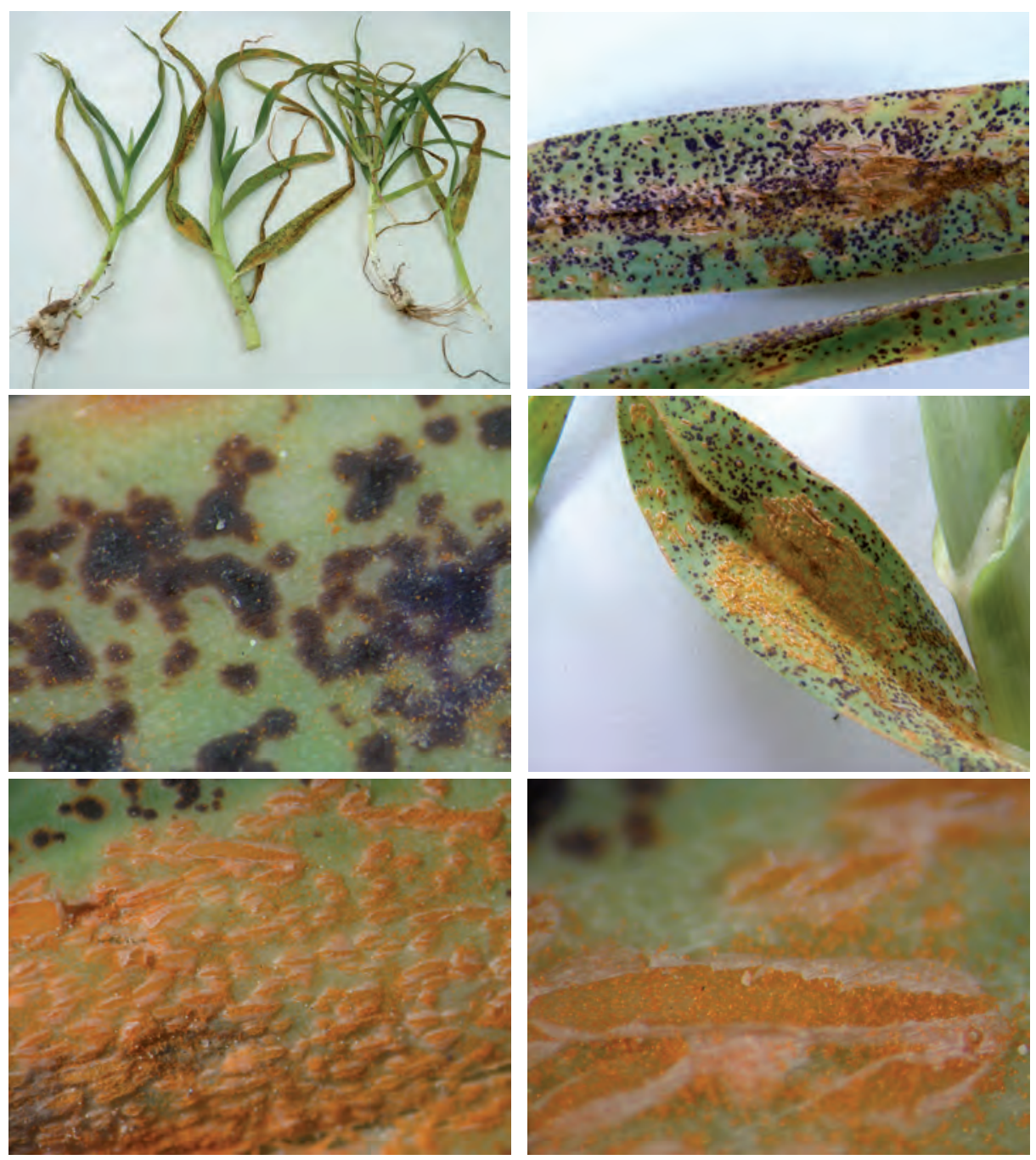

Figura 8. Rovell de l'all, Puccinia porri. Uredinis, de color carabassa, plens d'urediniòspores, $\mathrm{i}$ telis, més foscos, on es produeixen les teliòspores

\section{Els carbons}

Hi ha un grup de fongs sapròfits facultatius que, quan actuen com a patògens, gairebé sempre ataquen els ovaris (encara que també poden atacar les anteres, les fulles o les llavors) de la planta hoste, on produeixen gran quantitat d'espores (teliòspores, concretament) que poden veure's com un polsim negre i pudent, d'on els ve el nom popular de carbó, que s'aplica a les malalties que provoquen. Sobre els cereals (blat, ordi i avena) trobem dos tipus de carbó: els despullats, que destrueixen la cariopsi i els embolcalls florals, i els vestits, que respecten aquests últims. Ustilago tritici Bauhin provoca el carbó despullat del blat (figura 9); U. nuda Schaffmot, el de l'ordi, i U. avenae (Pers.) Rostr., el de l'avena. Ustilago levis (Kellerm i Swingle) Magnus provoca el carbó vestit de l'avena, i U. hordei Bref., el de l'ordi. Finalment, Ustilago maydis (DC.) Corda provoca la malaltia de les bossetes del panís, caracteritzada per les enormes tumoracions (fins a uns centímetres de 
diàmetre) que provoca, tant en fulles com en tiges, inflorescències, i grans d'aquesta planta (figura 10). Tots aquests fongs pertanyen a la família dels ustilaginacis, però hi ha una altra família, molt pròxima taxonòmicament, la dels til·letiacis, que produeixen una simptomatologia molt semblant.
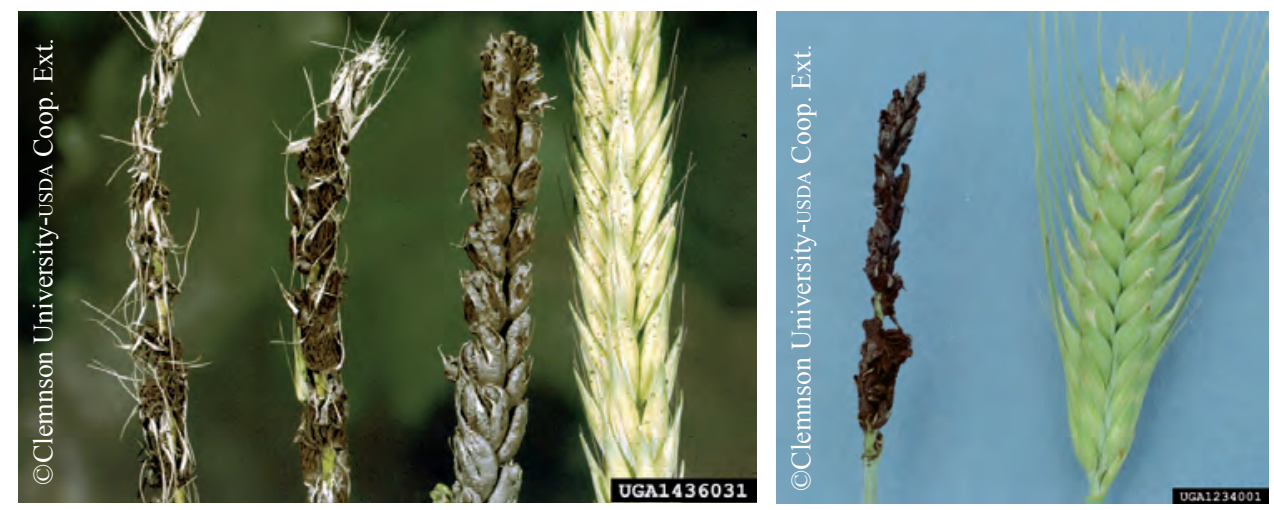

Figura 9. Malaltia del carbó despullat del blat causada pel fong Ustilago tritici
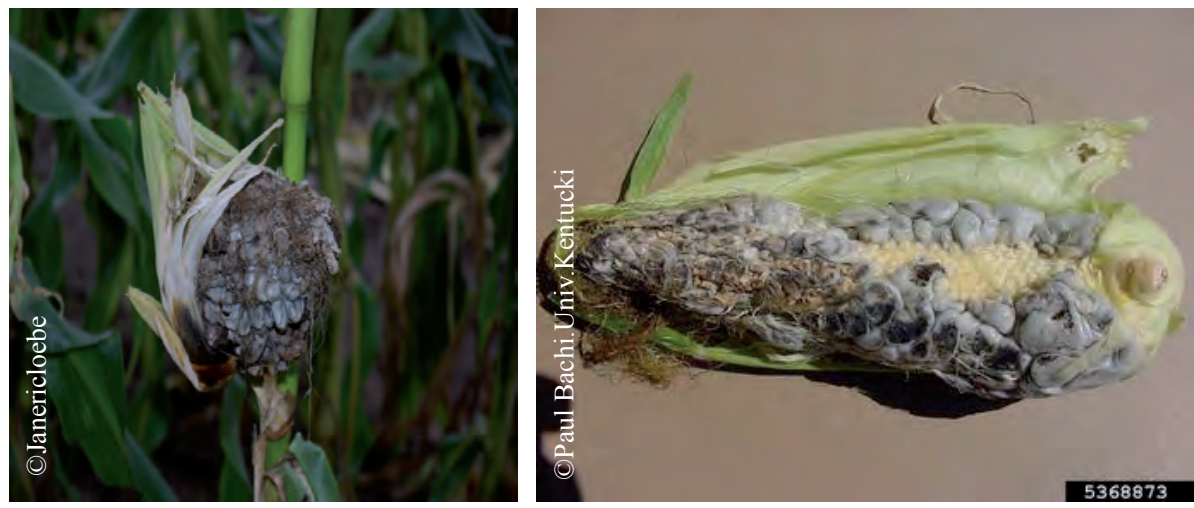

Figura 10. Malaltia de les bossetes del panís causada pel fong Ustilago maydis

Entre els til-letiacis, hi trobem dos gèneres d'interès: Tilletia i Urocystis. Tilletia caries (DC.) Tul. i C. Tul. és l'agent causal del blat orb (o càries del blat). Urocystis cepulae Frost provoca el carbó de la ceba i el porro, malaltia que es manifesta en forma d'estries argentades que, posteriorment, passen a negres, i que pot acabar matant plantes de planter (figura 11). 

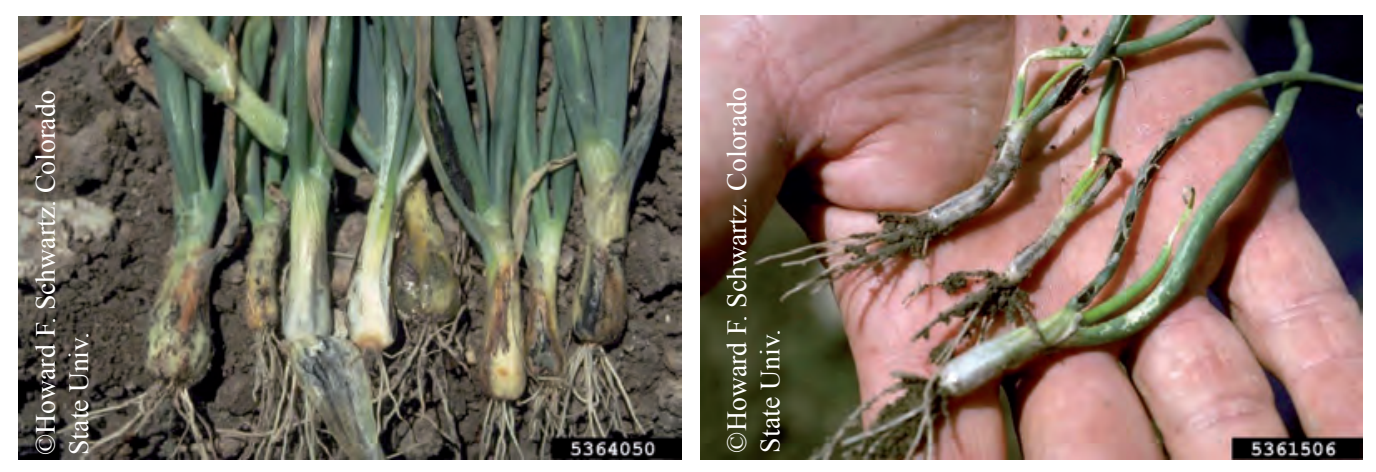

Figura 11. Malaltia del carbó de la ceba causada pel fong Urocystis cepulae

\subsubsection{Divisió Ascomycota: els oïdis i la fumagina}

\section{Els oïdis}

Es tracta d'un grup de fongs que cobreixen superficialment la planta parasitada, de manera que l'aparença que pren el vegetal atacat és com si una teranyina blanquinosa l'estiguera recobrint. Aquests fongs es reprodueixen asexualment mitjançant conidis, de forma més o menys ovalada, que reben el nom d'oïdis (mot que en grec vol dir ' ou'). Aquests oïdis formen llargues cadenetes al capdamunt d'una hifa diferenciada, i són els responsables que les parts atacades queden empolsinades, d'ací els ve el nom vulgar que rep a les nostres terres aquesta malaltia: cendra, cendrosa, cendrada, blanqueta, etc. La morfologia dels oïdis i dels conidiòfors és la base per a la distinció dels diversos gèneres anamòrfics, on destaquen Oidium, Oidiopsis i Ovulariopsis. A banda d'aquest tipus de reproducció, en determinades circumstàncies (normalment cap a l'hivern), alguns oïdis es reprodueixen també sexualment. En les nostres condicions açò no sol passar sovint. La fructificació teleomòrfica que produeixen aquests fongs pertany als ascomicets erisifals, i consisteix en unes esferes molt menudes, sovint amb uns apèndixs, els fulcres, que anomenem clistotecis. La morfologia dels clistotecis i la disposició i forma dels fulcres té importància taxonòmica (figura 12). Amb aquesta informació i amb la del nombre d'ascs (únic o diversos), podem arribar a determinar-ne el gènere: un sol asc, Podosphaera o Sphaeroteca, i més d'un, Erysiphe, Microsphaera, etc. 


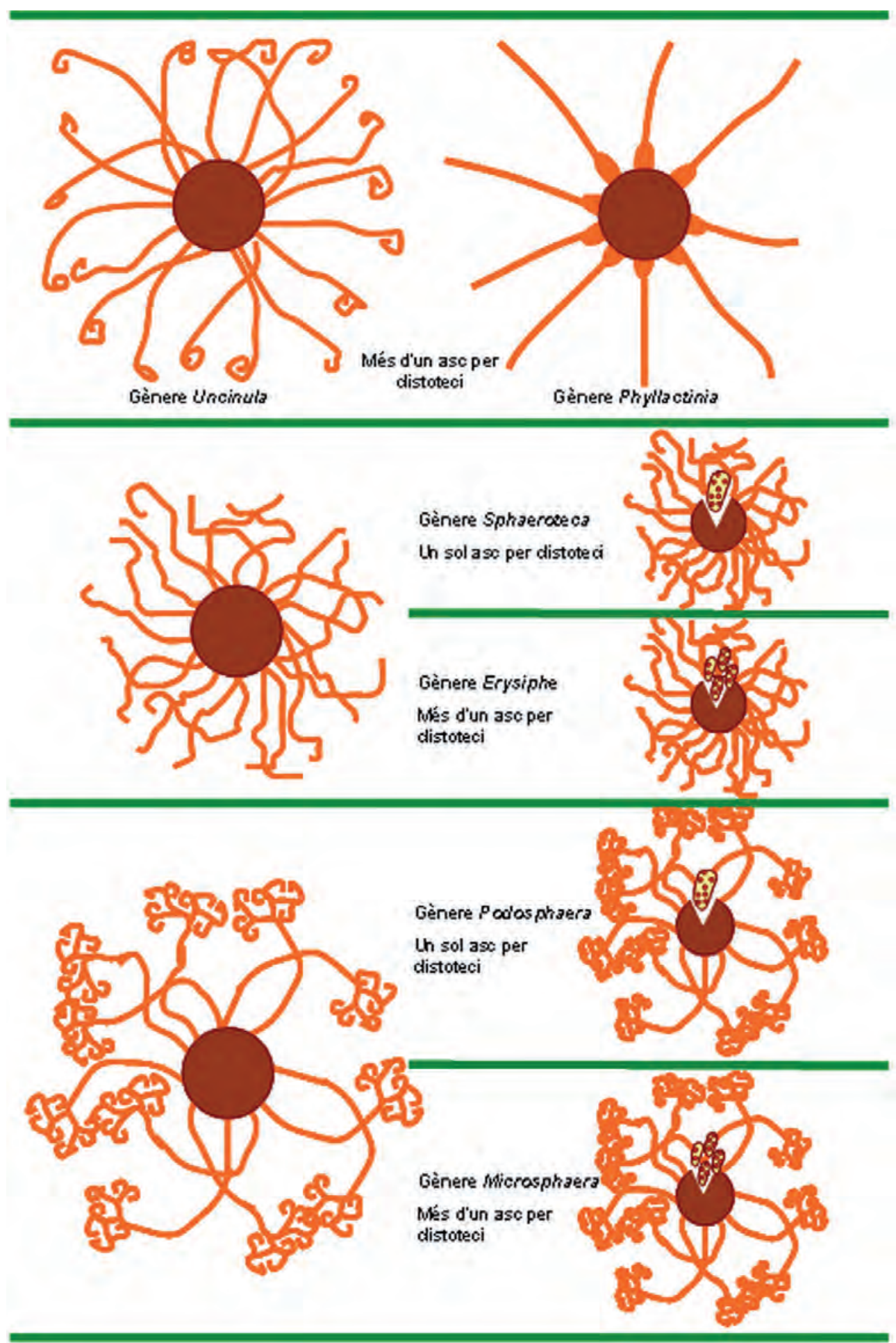

Figura 12. Clau simplificada per als gèneres més importants dels Erysiphaceae, basada en la morfologia dels clistotecis, els seus fulcres i el nombre d'ascs que contenen 
Les cendres ataquen moltes espècies, tant cultivades com silvestres. Les plantes parasitades tenen un aspecte cendrós a causa de l'enorme quantitat d'oïdis en cadena que se'ls acumulen sobre la superfície. En alguns casos semblen teranyines (con en els rosers), en d'altres formen denses pelfes cotonoses (plàtans d'ombra), o una mena de crostes blanques (evònim). Molts oïdis son polífags; per exemple, Oidium erysiphoides Fr. pot parasitar més de cinc-centes espècies vegetals diferents. N'hi ha d'altres, però, que tenen un rang d'hostes molt més restringit, com és el cas d'Uncinula necator (l'oïdi de la vinya) (figura 3), o de Microsphaera alphitoides Griffon i Maubl. (l'oïdi dels roures) (figura 13). La majoria dels oïdis que trobem en les nostres condicions rarament formen clistotecis, per la qual cosa es comporten normalment com a imperfectes.
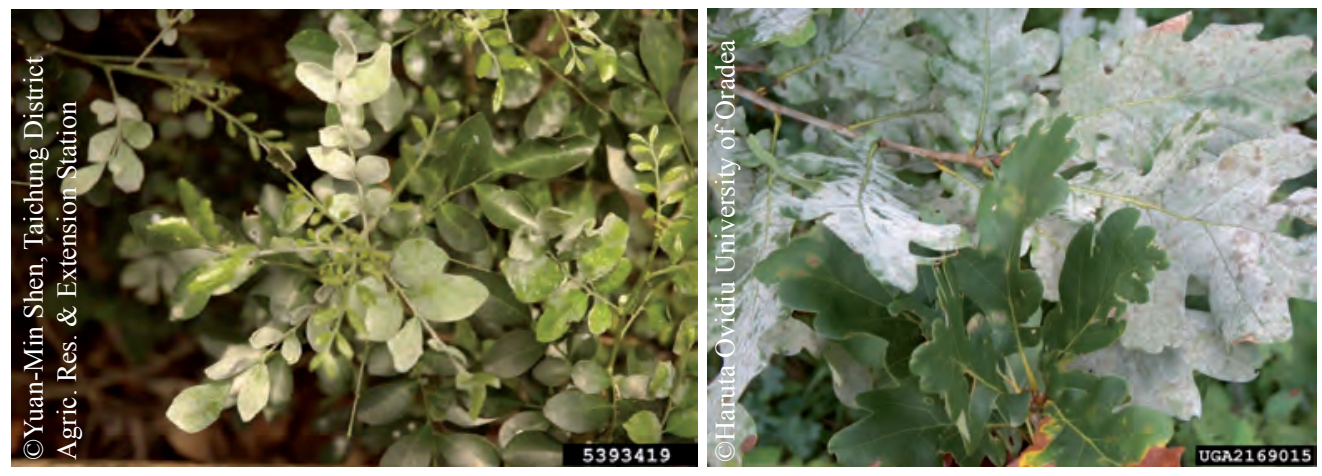

Figura 13. A l'esquerra, Oidium murrayae Hosag., U. Braun i Rabindran en la planta Murraya exotica (L.) Jack. A la dreta, Microsphaera alphitoides atacant una varietat de roure

\section{La fumagina}

La fumagina (també coneguda amb els noms de màscara, mascarell, negror, etc.) es presenta sobre la superfície dels vegetals afectats com una mena de sutge superficial, a voltes tan dur com una crosta, i la podem fer saltar amb el dit quan la freguem (figura 14). Això és així perquè la fumagina no és un veritable fong patogen, sinó un sapròfit que creix a partir dels exsudats d'homòpters com els pugons o les cotxinilles. Quan s'alimenten, aquests insectes picadors-xucladors extrauen el seu aliment del floema de les plantes, que és molt ric en sucres però pobre en substàncies nitrogenades. Per tal de cobrir les seues necessitats de nitrogen, doncs, aquestes bestioles han d'ingerir un excés de sucres, que després excreten en forma de melasses. Són precisament aquestes melasses les que aprofiten les fumagines per al seu creixement. Encara que, com hem dit, les fumagines no són patògens en sentit estricte, el fet que entapissen la superfície del vegetal fa que els estomes s'obturen, en dificulten tant la transpiració, com la respiració i la fotosíntesi, i causen un dany directe a la planta. A més, l'aspecte brut que confereixen al vegetal fa que aquest perda valor comercial (tant en planta ornamental com en fruita o verdura) i ens obliga a haver de posar algun tipus de rentat que lleve la màscara durant el procés de comercialització. Per tot això la fumagina té importància com a fong fitopatogen. 
Quan observem les fumagines a la lupa, és difícil que puguem veure estructures de reproducció sexual. Normalment no veurem més que les masses micelials fosques, que es componen de cèl·lules arrodonides, que formen hifes robustes, de parets gruixudes, i que solen agrupar-se en masses esponjoses. El fong causant de la fumagina en les nostres condicions sol ser Capnodium elaeophilum Prill., molt freqüent en olivera, cítrics i ornamentals infestats per pugons o per còccids.
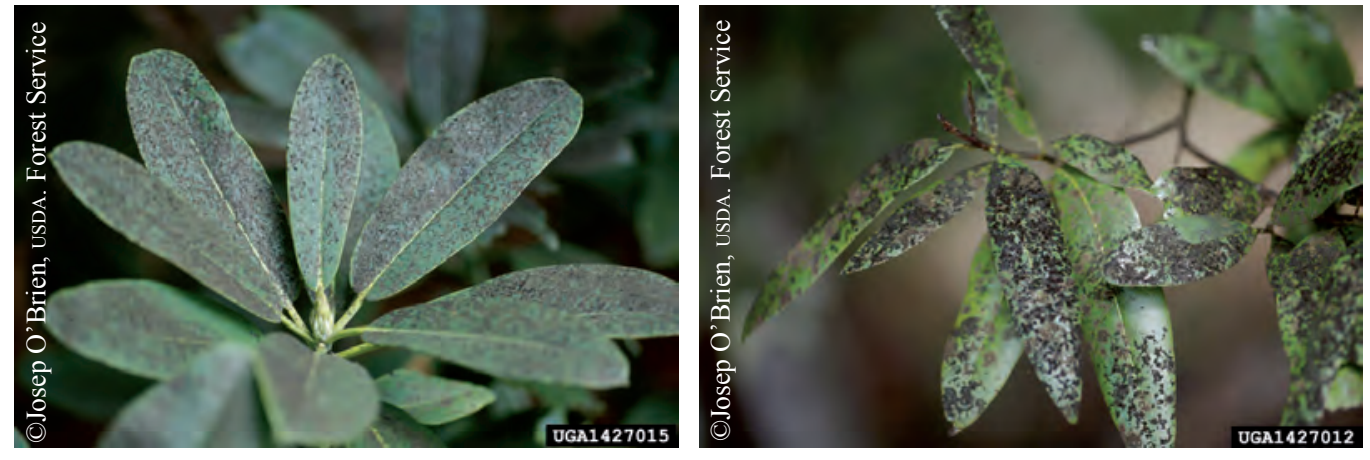

Figura 14. Símptomes de fumagina en el llorer de Califòrnia, Umbellularia californica (Hook. i Arn.) Nutt

\subsection{Clau simplificada per a la classificació dels fongs fitopatògens}

La clau que seguirem i que figura a continuació, inclou tant els fongs veritables (Regne Fungi) com els regnes afins (Regne Protozoa i Chromista), que configuren el que en fitopatologia es coneix normalment com a fongs fitopatògens.

\begin{tabular}{|c|c|c|}
\hline 1. & $\begin{array}{l}\text { Plasmodi o pseudoplasmodi present. } \\
\text { Fase assimilativa típicament filamentosa. }\end{array}$ & $\begin{array}{l}\text { Regne Protozoa. Divisió } \\
\text { Mixomycota } \\
2\end{array}$ \\
\hline 2. & $\begin{array}{l}\text { Hifes filamentoses contínues, rarament septades. } \\
\text { Hifes filamentoses septades (o llevats). }\end{array}$ & $\begin{array}{l}3 \\
4\end{array}$ \\
\hline 3. & $\begin{array}{l}\text { Espores asexuals mòbils (zoòspores) biflagel·lades; espores } \\
\text { sexuals: oòspores. } \\
\text { Espores asexuals mòbils (zoòspores) uniflagel·lades; repro- } \\
\text { ducció sexual molt rara. } \\
\text { Espores asexuals esporangiòspores. Espores sexuals: zigòs- } \\
\text { pores. }\end{array}$ & $\begin{array}{l}\text { Regne Chromista. Divisió } \\
\text { Oomycota } \\
\text { Regne Fungi. Divisió } \\
\text { Chytridiomycota } \\
\text { Regne Fungi. Divisió } \\
\text { Zygomycota }\end{array}$ \\
\hline 4. & $\begin{array}{l}\text { Espores sexuals: basidiòspores. Espores asexuals absents, } \\
\text { conidis o bé formes especials (rovells). } \\
\text { Espores sexuals (quan en presenten): ascòspores. Propa- } \\
\text { gació asexual per conidis o per troços de miceli (fongs } \\
\text { imperfectes, Mycelia sterilia). }\end{array}$ & $\begin{array}{l}\text { Regne Fungi. Divisió } \\
\text { Basidiomycota } \\
\text { Regne Fungi. Divisió } \\
\text { Ascomycota }\end{array}$ \\
\hline
\end{tabular}




\section{Objectius de la pràctica}

Els objectius d'aquesta pràctica es concreten en tres:

1. Familiaritzar-se amb la morfologia i els diferents òrgans de fructificació i espores d'alguns fongs fitopatògens importants (oïdis, rovells, fumagina, etc.).

2. Aprendre a utilitzar la càmera humida, la lupa i els microscopis per al diagnòstic de fongs fitopatògens.

3. Identificar alguns dels fongs d'importància agronòmica més comuns.

\section{Desenvolupament de la pràctica}

\subsection{Material}

El material necessari per dur a terme aquesta pràctica és:

- Material vegetal

- Plaques de Petri

- Càmera humida

- Paper de filtre

- Tisores

- Lupa binocular

- Microscopi

- Lactofenol o fucsina àcida (tint)

- Espàtula

- Portaobjectes

- Cobreobjectes

- Clau taxonòmica proporcionada

\subsection{Metodologia}

A partir del material vegetal de què disposem (plantes malaltes), el colllocarem en càmera humida (per tal que fructifique) o no (si ja tenim les fructificacions presents). Observant directament la mostra a la lupa binocular, podrem saber si el fong ja ha fructificat o si cal deixar-lo més temps.

Sobre un portaobjectes ben net, col-locarem una gota del medi de muntatge al mig. Podem treballar simplement amb aigua, que ens permetrà apreciar els colors naturals de les estructures, però com que té l'inconvenient d'evaporar-se molt ràpidament, utilitzarem lactofenol o fucsina àcida.

La gota que posarem haurà d'ésser xicoteta, per tal d'evitar que el cobreobjectes «nade» i la preparació quede excessivament gruixuda i bruta. Agafarem el material que cal observar en quantitats mínimes i amb agulles fines o llancetes, i el dipositarem amb cura sobre la goteta. 
En prendre el material cal tenir en compte que, per poder identificar els fongs, el que més ens interessa no són els nombrosos conidis que ompliran la preparació, sinó els conidiòfors que els suporten, ja que la seua morfologia és la que pot permetre'ns identificar l'espècie en qüestió. Per tant, si es tracta d'un hifomicet, cal que agafem el material mitjançant dues agulles, des de la base per no malmetre els conidiòfors, i si cal (per exemple, Aspergillus, Gliocladium, Penicillium, Trichoderma, etc.), primer els podem passar a una gota de lactofenol, on esbandirem l'excés de conidis abans de passar-los a la gota definitiva.

Si es tractara d'un erisifal (oïdis), també amb agulles llevaríem els clistotecis del substrat (on apareixen com puntets negres), i els col-locaríem sobre la gota de lactofenol, on els aixafaríem suaument amb el cobreobjectes per poder observar els ascs que contenen. Procediríem de forma molt semblant en el cas d'haver d'observar altres fructificacions, ja foren d'origen sexual (peritecis, apotecis) o asexual (picnidis, acèrvuls).

Una vegada tinguem la mostra distribuïda per la gota, de manera que no quede material amuntegat, haurem de tapar-la amb cura amb el cobreobjectes. Hem de començar a col·locar-lo per un cantó, deixant que caiga a poc a poc, per tal d'evitar la formació de bombolles entre els vidres.

Al microscopi observarem tot allò que es puga veure de la mostra: les hifes, presència d'espores especials, morfologia dels conidiòfors, forma i ornamentació de les espores, etc. 


\title{
PRÀCTICA 5
}

\section{Estimació de l'eficàcia d'un tractament} contra la mosca mediterrània

\author{
de la fruita, Ceratitis capitata
} (Wiedemann) (Diptera: Tephritidae). A. Quarantena per fred. B. Tractament insecticida

\section{Antecedents}

\subsection{La mosca mediterrània de la fruita, Ceratitis capitata}

La mosca mediterrània de la fruita, Ceratitis capitata (Wiedemann) (Diptera: Tephritidae), és una espècie de climes temperats càlids, molt comuna a tot el litoral mediterrani. En les nostres condicions climàtiques podem trobar tots els estats de desenvolupament (ous, larves, pupes i adults) (figura 1) en qualsevol moment de l'any.

Quan les femelles troben fruita receptiva (amb un grau de maduresa suficient), hi claven el seu oviscapte i hi ponen entre 1 i 12 ous. Com que més d'una femella pot fer la posta en un sol fruit, la quantitat d'ous (i consegüentment, després, de larves) que es pot trobar per fruit pot ser molt alta, sobretot si es té en compte que la fecunditat d'aquesta espècie és molt elevada, i una femella pot arribar a pondre fins a 600 ous al llarg de la seua vida. Després de l'eclosió dels ous, les larves nounades s'alimenten de la polpa de la fruita fins a completar el seu desenvolupament al final del tercer estadi larval (mida aproximada d'1 cm). En aquest moment, les larves es dirigeixen cap a l'exterior del fruit, i salten al sòl, on buscaran un lloc on soterrar-se i pupar.

En condicions d'estiu, la mosca pot completar el seu cicle en dues o tres setmanes, és a dir, que en quinze o vint dies podem trobar una nova generació de mosca. La durada de tot el procés depèn de factors com la temperatura, la humitat, la vegetació, el substrat de posta dels ous i de pupació, la disponibilitat d'aliment, etc. (Aluja, 1993). 


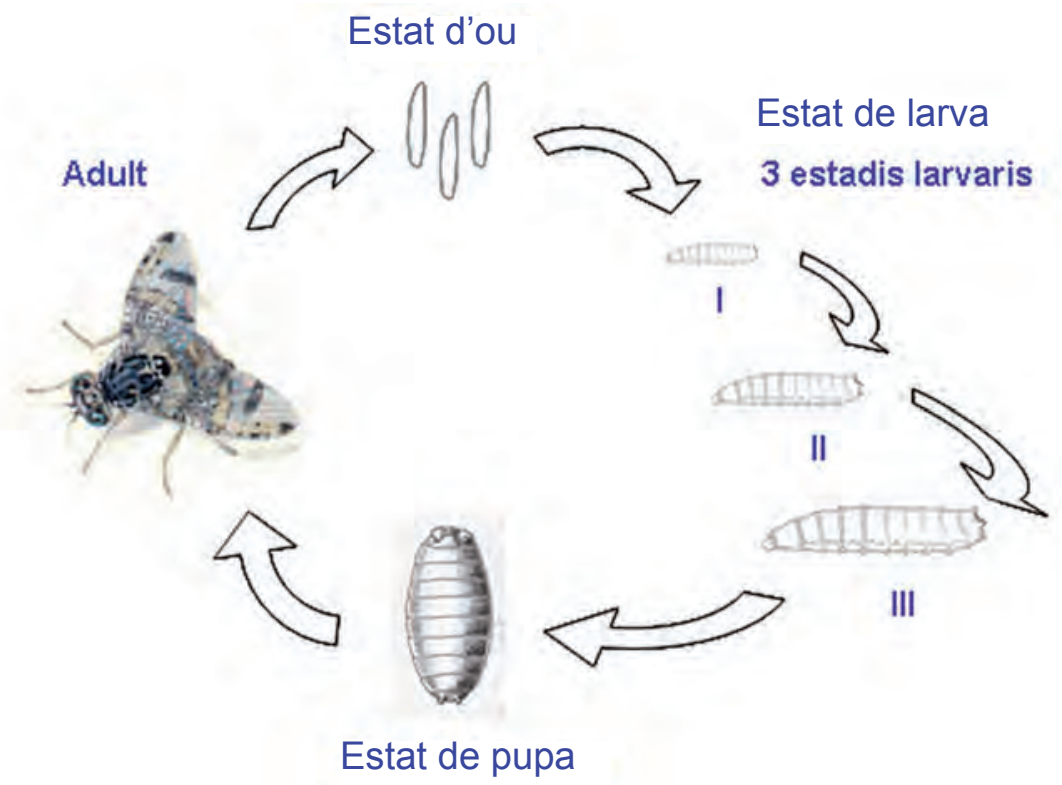

Figura 1. Esquema dels estats i estadis de desenvolupament de Ceratitis capitata

Ceratitis capitata és una espècie molt polífaga, i està citada sobre més d'un centenar d'hostes diferents. Malgrat això, prefereix la fruita de pinyol (albercocs, bresquilles, prunes, etc.), però quan no troba aquestes espècies típicament estivals, la mosca es pot reproduir tant sobre fruita de grana (pomes, peres), com d'altres (raïm, tomaca, nespres, etc.). Donat que a l'hivern, en les condicions de la nostra zona, els cítrics són pràcticament l'única espècie hoste que els queda, s'hi refugien $i$ es converteixen en una plaga important d'aquest cultiu.

Els danys, tant directes com indirectes, que provoca $C$. capitata són molt importants. D'una banda, els fruits atacats es perden totalment, ja que solen caure prematurament de l'arbre com a conseqüència de la posta de la femella, posterior desenvolupament de la larva i consegüent activació dels processos d'oxidació i maduració prematura (figura 2). D'altra banda, les picades de posta es converteixen en porta d'entrada per a altres plagues o altres afeccions causades per fongs $i$ bactèries, i la fruita atacada sol podrir-se fàcilment i resulta invendible. A aquests danys en la fruita cal afegir altres pèrdues econòmiques fruit de la presència de picades de posta (acompanyada sovint de la d'immadurs en el seu interior), que ocasiona que la fruita siga rebutjada als mercats internacionals on C. capitata és una plaga d'importància quarantenària pel fet de no ser-hi present (llista A2 de l'OEPP, en anglès EPPO, European and Mediterranean Plant Protection Organization (http://www.eppo.int/QUARANTINE/quarantine.htm)), com és el cas dels Estats Units o el Japó, on es dirigeix una part qualitativament important de les exportacions hortofructícoles espanyoles. El fet que una espècie es considere plaga quarantenària suposa la generació d'uns protocols d'aplicació i seguiment obligatori per a la fruita que es vulga exportar. Aquests regulen des de la vigilància i seguiment de les parcel·les, fins als tractaments fitosanitaris que cal aplicar (plaguicides, fungicides, herbicides, reguladors de creixement, tractaments postcollita), com la visita obligada d'una empresa auditora tant al camp com al magatzem de confecció que certifique que s'han complit tots els requisits exigits en el programa d'exportació de cítrics. 


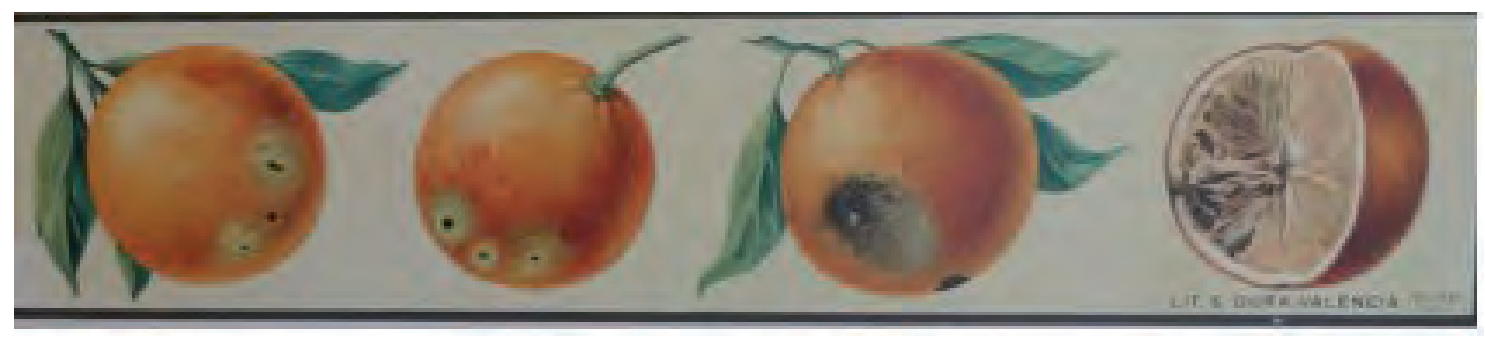

Figura 2. Fruita amb danys de Ceratitis capitata

La lluita contra aquest flagell es basa en la detecció precoç de les primeres femelles adultes als horts i el seguiment de les seues poblacions al llarg del període en què la fruita és susceptible al seu atac. Això se sol fer mitjançant l'ús de mosquers (secs o humits). Quan les captures indiquen la necessitat de fer un tractament, es pot recórrer a tractaments aeris (a hores d'ara prohibits a Espanya) o bé terrestres. Normalment els tractaments es fan mesclats amb una proteïna, que actua com a esquer. També s'ha utilitzat la tècnica dels mascles estèrils o TIE (en anglès, Sterile Insect Technique, SIT), mètode que veurem en més detall quan tractem l'eixida a la planta de producció de mascles estèrils a Caudete de las Fuentes. I per últim, en el cas de les exportacions a països on no hi ha mosca, el tractament que se segueix és sotmetre la fruita a una quarantena.

\subsection{Els tractaments de quarantena}

Els tractaments de quarantena o tractaments quarantenaris, que s'enquadren dins del que denominem mètodes de lluita legal, han d'assegurar que el moviment dels productes agrícoles no implique un risc excessiu de disseminació de plagues i malalties. A més, com que aquests tractaments s'han d'aplicar a fruites i hortalisses, cal que no alteren les propietats organolèptiques d'aquestes mercaderies ni suposen problemes d'impacte ambiental o per a la salut humana (com ha passat per exemple amb el bromur de metil, ara prohibit), malgrat ser molt efectius.

En línies generals, perquè un tractament quarantenari siga acceptat, ha de complir uns requisits mínims (Del Río et al., 2008):

- Ha de ser efectiu contra la plaga que es vol eliminar del fruit o de l'hortalissa (com veurem més endavant, cal un pròbit 9 , és a dir, un tractament serà efectiu només si queda 1 o menys supervivents en un milió).

- No ha de tenir efectes perjudicials en la qualitat, emmagatzemament o composició del producte tractat.

- El producte emprat no ha de deixar cap residu que puga ser perillós per al consumidor, entenent per residu qualsevol producte fitosanitari o altres reaccions químiques que puguen produir-se com a conseqüència del tractament.

- L'execució del tractament no ha de ser perillosa per al personal que l'aplique.

- El temps i cost del procés ha de ser reduït, de manera que puga integrar-se en l'activitat del magatzem i/o transport. 
Els tractaments emprats actualment per a quarantena poden ser de tipus químic o físic (Follet i Neven, 2006; Palou et al., 2007; Del Río et al., 2008). Els productes químics que s'han emprat tradicionalment són fumigants com dibromur d'etilè (EDB), bromur de metil (MB), àcid cianhídric $(\mathrm{HCN})$, sulfur de carbó $\left(\mathrm{CS}_{2}\right)$, fosfina $\left(\mathrm{PH}_{3}\right)$ i altres gasos. La majoria d'aquests productes són cancerígens, quan no tòxics o inflamables, la qual cosa ha fet que es busquen tractaments alternatius malgrat la seua elevada eficàcia. També existeixen sabons i insecticides per eliminar aquells insectes que es troben a la superfície del fruit.

Entre els mètodes físics utilitzats en la quarantena contra plagues trobem la ionització o radiació, les atmosferes controlades, els tractaments tèrmics o una combinació d'aquests. Existeixen diferents tipus d'ionització o radiació, com les microones, ones de ràdio, raigs $\mathrm{UV}, \mathrm{IR}, \mathrm{X}, \gamma$, etc., on l'efectivitat del tractament depèn de la dosi necessària per matar a les plagues i de la absència de residus o d'alteracions en el producte. Els problemes poden vindre d'un ablaniment i d'un enfosquiment dels teixits. Les atmosferes controlades (jugant sobretot amb les concentracions de $\mathrm{CO}_{2} \mathrm{i} \mathrm{d}^{\prime} \mathrm{O}_{2}$ ), poden ser una bona tècnica de quarantena, a més de funcionar com a complement de la frigoconservació de productes vegetals frescs o mínimament processats. Tanmateix, poden provocar mals sabors o olors, incrementar la susceptibilitat a algunes podridures, etc. Les variables que afecten l'eficàcia d'aquesta tècnica són múltiples, com la composició de l'atmosfera, temperatura, humitat, temps d'exposició, espècie i estat de desenvolupament de l'insecte. Per últim estan els tractaments tèrmics, que poden ser amb calor o amb fred. Els tractaments amb calor consisteixen en sotmetre els fruits a elevades temperatures mitjançant: 1.- Immersió de la fruita en aigua calenta, que és altament efectiva en fruites tropicals, però en cítrics poden modificar el sabor i danyar-ne la pell; 2.- Amb vapor humit, si bé en alguns casos poden ser fitotòxics; o 3.- Amb aire calent forçat, que presenta l'inconvenient que pot produir pèrdues de pes o emmusteïment prematur. Per contra, els tractaments amb fred, a més de ser la principal tècnica de conservació dels fruits gràcies que alenteix els processos d'envelliment del fruit, actualment juguen un paper molt important en el control de plagues quarantenàries.

\subsection{Quarantena per fred}

La quarantena per fred consisteix en sotmetre la mercaderia (fruites o hortalisses) a una temperatura de refrigeració específica durant un període de temps suficient com per matar la plaga diana (USDA. Rules and Regulations. Federal Register, Vol. 75, No. 16. January 26, 2010). Els avantatges que presenta aquest tractament són l'absència de residus químics, el manteniment de la qualitat del producte i una menor incidència de les podridures. L'únic desavantatge és el dany per fred en la pell, sobretot en fruites tropicals.

Aquest tractament quarantenari és el procediment que s'empra per exportar cítrics lliures de qualsevol estadi viu de mosca mediterránia de la fruita a un gran nombre de països com els EuA, el Japó o Austràlia, on no està present C. capitata. El tractament amb baixes temperatures s'inicia amb la càrrega al port d'eixida, 
es manté durant tot el viatge i finalitza normalment alguns dies després d'arribar a destinació. El temps que estarà exposada la mercaderia a la baixa temperatura variarà en funció de la temperatura, de la varietat i del país on va destinada. En el cas concret de l'exportació de cítrics als EUA, les mandarines i taronges, per complir la quarantena, han de sotmetre's a l'interior de contenidors a una de les següents temperatures:

- $1,11^{\circ} \mathrm{C}$ durant 14 dies

- $1,66^{\circ} \mathrm{C}$ durant 16 dies

- $2,22^{\circ} \mathrm{C}$ durant 18 dies

En sobrepassar una d'aquestes temperatures, es passaria a la següent (USDA. Rules and Regulations. Federal Register, Vol. 67, No. 203. October 21, 2002). En el cas de les llimes, fins al 18 de març de 2010 no s'exigia cap tractament amb fred, donat que es pensava que no era fruita susceptible de ser portadora de C. capitata. No obstant, com a conseqüència de la detecció de larves vives en un enviament de llimes des d'Espanya el 2006, les autoritats americanes van reconsiderar la possibilitat d'incloure també aquest cítric com a article regulat. Fruit d'aquesta proposta, des d'abril de 2010 també és obligatori un tractament amb fred en totes les varietats de llima, Citrus limon (L.) Burm F. (USDA. Rules and Regulations. Federal Register. March 18, 2010). Aquest fet pot suposar alguns problemes afegits, atesa la sensibilitat al fred de les llimes, com passa amb les aranges i els híbrids com Nova o Fortune on, com a conseqüència de les baixes temperatures, es pot provocar l'aparició de taques a la corfa, que fins i tot poden afectar l'interior del fruit.

Quan la fruita s'embarca cap als EUA, un inspector espanyol acompanyat d'un altre d'americà verifiquen que tot està funcionant correctament al vaixell (sensors de temperatura d'aire i de polpa, reglamentació del vaixell i de la càrrega, mostra inspeccionada lliure de plaga...) i n'autoritza l'eixida amb la càrrega. Una vegada arriba al port de destí i superat el temps establert, la mercaderia és rebuda per un altre inspector espanyol i un d'americà, que comproven que s'ha complit la quarantena i que la fruita està en les condicions adequades per ser desembarcada. En la major part dels casos, el vaixell fa port abans de complir els dies fixats; en aquest cas roman al port fins que finalitza la quarantena (figura 3). 

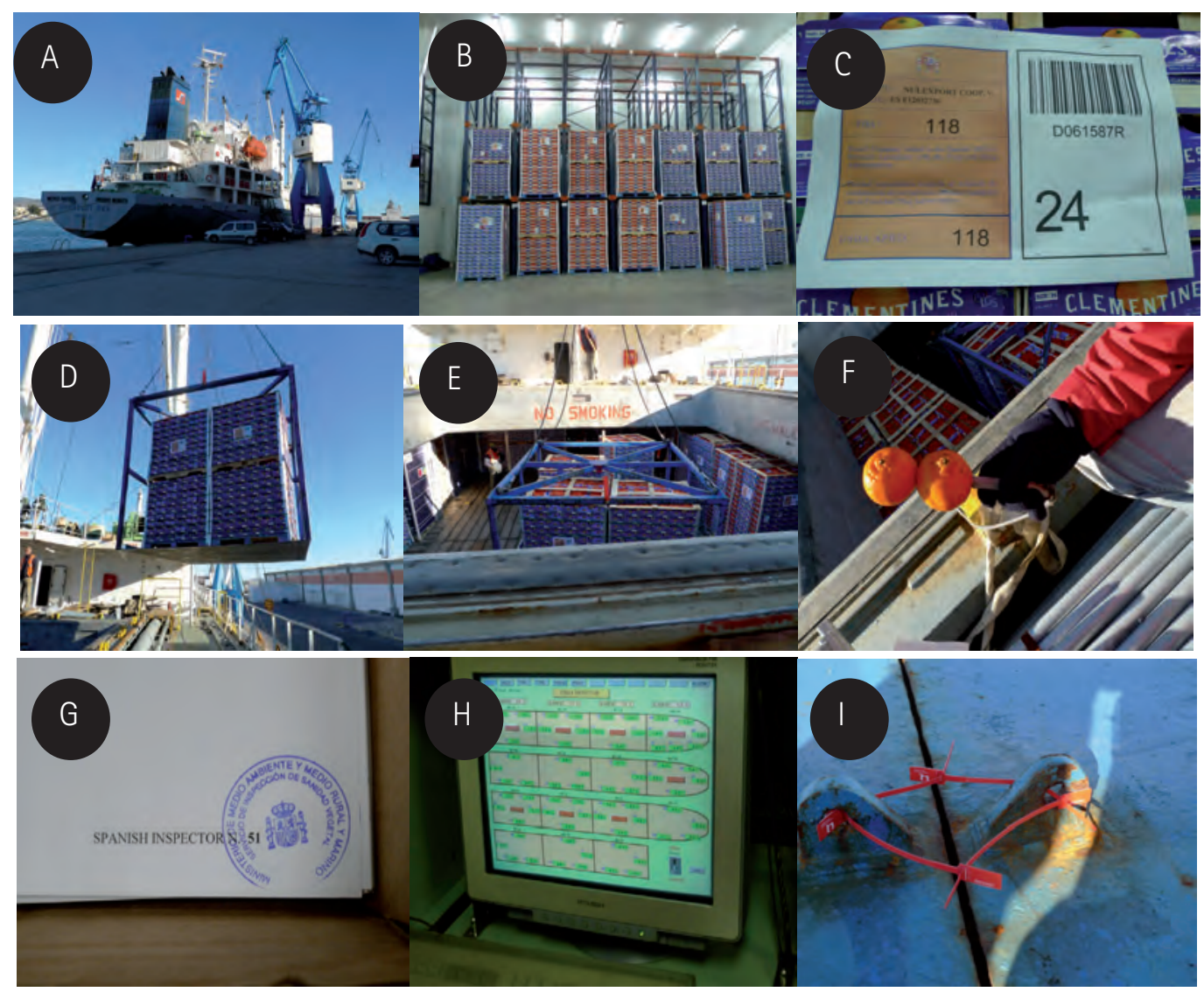

Figura 3. Imatges del procés d'exportació de clementines als EuA. A) Vaixell on es transporta la mercaderia; B) emmagatzematge de la fruita abans de ser carregada al vaixell. La temperatura ha d'estar al voltant d' $1^{\circ} \mathrm{C}$; C) etiqueta on vénen ressenyades les dades de l'empresa exportadora, nr. de lot USDA-APHIS, nr. de lot FDA...; D) i E) diferents moments de la càrrega de la mercaderia; F) sensor de temperatura de polpa amb dues clementines punxades. La temperatura d'aquests sensors ha de mantindre's constant al llarg de tota la quarantena; G) paper signat i numerat pel ministeri. En aquest paper s'enregistra cada hora les temperatures de tots els sensors. Aquestes dades seran revisades pels inspectors americans i espanyols, que comprovaran que la quarantena s'ha fet bé i que no hi manca cap paper. En funció de la impressora aquest paper pot ser continu o amb fulls solts; $\mathrm{H}$ ) distribució dels sensors en cada bodega del vaixell; I) precintatge de la bodega una vegada finalitzada la càrrega i comprovat que els sensors funcionen correctament. Aquest precinte ha d'estar intacte quan arribe al port de destí

\subsection{Els insectes i la temperatura}

Els tractaments de quarantena amb temperatura són efectius contra les plagues perquè aquests són animals poiquilotèrmics, és a dir, són animals que no poden regular la temperatura del seu cos generant calor, de manera que aquesta varia amb l'ambient. Per aquesta raó, la durada del seu cicle és variable en funció de la temperatura, $\mathrm{i}$ es desenvolupen en general més ràpidament com més alta és la temperatura, però sempre dins d'uns límits (figura 4). 


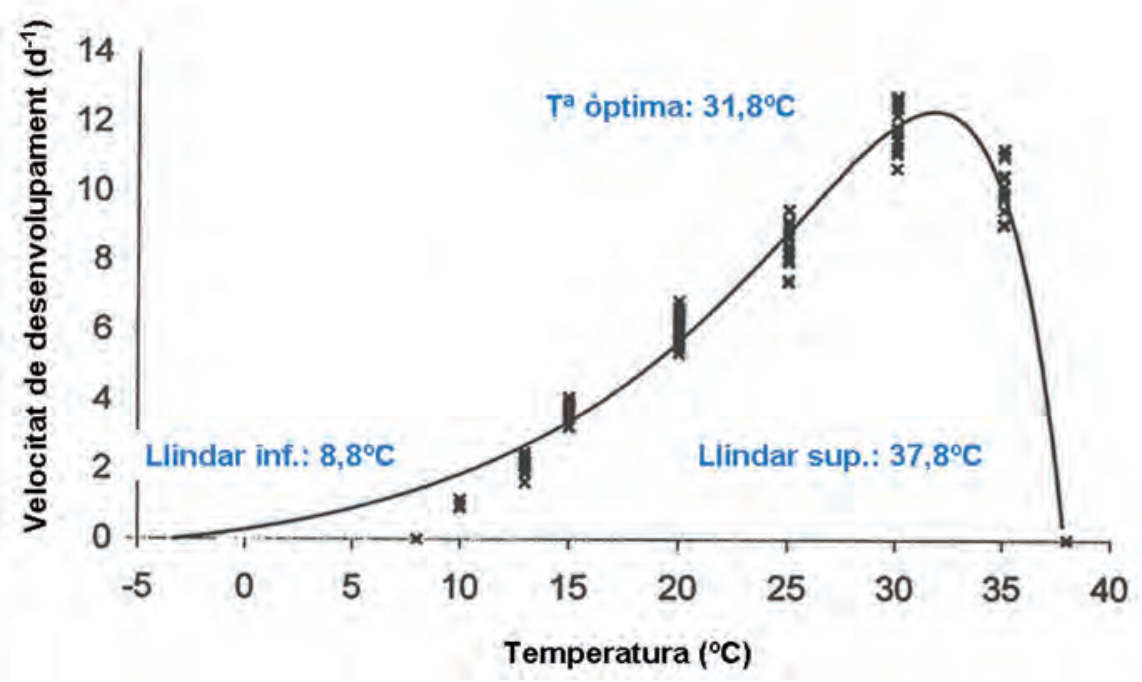

Figura 4. Velocitat de desenvolupament ( dies $\left.^{-1}\right)$ de Cirrospilus brevis Zhu, LaSalle i Huang (Hymenoptera: Eulophidae) criat sobre la minadora de les fulles dels cítrics, Phyllocnistis citrella Stainton (Lepidoptera: Gracillaridae), en fulles de cítrics a diferents temperatures $\left({ }^{\circ} \mathrm{C}\right)$. Ajust del model de Logan, 2a. modificació. Adaptat d'Urbaneja et al. (1999)

Tots els insectes presenten una temperatura òptima de creixement (aquella on la velocitat de creixement és màxima) i dos llindars: l'inferior (a partir del qual pot calcular-se la integral tèrmica d'un insecte) i el superior. A aquestes temperatures l'insecte no mor, però deixa de créixer. Un poc més enllà d'aquests llindars, apareixen les temperatures letals (també superior i inferior), que provoquen la mort de l'insecte. La letalitat de qualsevol temperatura depèn, òbviament, del temps d'exposició, ja que molts insectes poden suportar temperatures extremes durant un curt període de temps. Per tal de definir una temperatura utilitzable en quarantenes, caldrà determinar, doncs, la temperatura letal i el temps d'exposició.

\subsection{Assaigs de toxicitat}

D'altra banda, si en lloc de plantejar la utilització de la temperatura com a agent letal volem estudiar les possibilitats d'una matèria activa com a biocida, una de les moltes proves que caldrà fer és l'estudi de la seua eficàcia sobre la plaga que volem combatre. Només quan es demostre que la matèria activa és efectiva contra un determinat flagell podrem plantejar-nos el seu ús amb aquesta finalitat.

Els estudis de toxicitat solen començar en laboratori, on es determina la corba d'activitat del producte. Cal relacionar la dosi amb l'efecte aconseguit i, partint d'aquesta funció, determinar-ne les dosis letals, tal com es veu a continuació. 


\subsection{Anàlisis de la mortalitat: Relació dosi - resposta}

Una manera d'avaluar els efectes d'un tractament químic (plaguicides) o físic (radiacions, temperatura, atmosferes insecticides), és analitzar si aquest pot provocar la mort dels individus d'una població experimental i, en aqueix cas, quin percentatge d'aquesta població es veu afectat. L'indicador que s'empra tradicionalment per avaluar aquesta mortalitat és la dosi letal $50\left(\mathrm{DL}_{50}\right)$, que és la dosi del producte que provoca la mort del 50\% dels individus de l'experiment. Anàlogament, la $\mathrm{DL}_{90}$ i la $\mathrm{DL}_{99}$ són les dosis del producte que provoquen la mort del $90 \%$ i del $99 \%$ de la població, respectivament. Com més alta siga la $\mathrm{DL}_{50}$ d'un producte, menys tòxic serà. Els plaguicides més moderns tenen $\mathrm{DL}_{50}$ més baixes per a les plagues i més altes per als humans. Aquestes dades són bàsiques abans de plantejar-nos altres assaigs de semicamp i de camp.

Quan el que s'avalua no és la concentració d'un producte biocida, sinó el temps d'exposició a un tractament necessari per a provocar la mort del $50 \%$ dels individus experimentals, parlem de temps letal $50\left(\mathrm{TL}_{50}\right)$. De la mateixa manera s'obtenen el $\mathrm{TL}_{90}$ i el $\mathrm{TL}_{99}$, és a dir, el temps d'exposició a un tractament necessari perquè mora el $90 \%$ i el $99 \%$ de la població.

Per calcular la DL o el TL s'utilitza el mètode d'anàlisi Pròbit o transformació Pròbit (de l'anglès, probability units). Aquesta transformació linealitza la relació del tractament i la resposta quan representa la mortalitat en unitats de probabilitat (pròbits), en funció del logaritme de la dosi del tractament.

En general, si representem la resposta d'una població experimental a un tractament biocida (\% de mortalitat o de supervivència, que són complementaris) respecte a la concentració del biocida o al temps d'exposició al tractament (químic o físic), el que obtindrem és una corba de tipus parabòlic o exponencial de difícil interpretació. Una manera de solucionar aquest problema consisteix a transformar la concentració de producte o el temps d'exposició al producte a una escala logarítmica $\left(x=\log _{10}\right.$ (concentració o temps d'exposició)). Això ens dóna una relació dosi - resposta en forma de corba sigmoide que aconsegueix normalitzar la distribució de la resposta. Aquesta transformació té sentit quan es parla d'insecticides, on la sensibilitat al producte és molt variable $\mathrm{i}$ es distribueix asimètricament al voltant de la mitja. Si a més de representar en abscisses $(x)$ el logaritme de la dosi o temps d'exposició, representem en ordenades (y) el percentatge de l'efecte (mortalitat corregida respecte al control), es corregeix aquesta asimetria. La corba sigmoide que s'obté d'aquesta manera es pot transformar en lineal mitjançant la transformació del percentatge de l'efecte en unitats pròbit amb l'ajut de les taules de pròbit (taula 5). D'aquesta manera la representació gràfica és més fàcil, $\mathrm{i}$ amb pocs punts es pot ajustar una recta, que respon a l'equació $y=a+b x$, i calcular la dosi o el temps letal que es busca. Amb la recta sol donar-se la bondat de l'ajustament mitjançant la prova d'hipòtesi de la $\chi^{2}$ i els seus límits fiducials (Throne et al.,1995a i b).

Aquesta recta pròbit ens permet comparar unes dades (rectes) amb altres de similars (altres tractaments, altres temps d'exposició) i determinar si les respostes 
són o no són diferents. D’aquesta manera, un desplaçament cap a la dreta de la recta indica més tolerància / resistència al tractament insecticida $o$, en el cas de parlar de temps, més temps d'exposició per matar les larves, mentre que un pendent més gran implica que els individus assajats són més homogenis en la resposta al tractament.

Aquest càlcul es pot fer manualment o mitjançant paquets estadístics ja preparats per fer anàlisis Pròbits com R, SAS, SPSS o POLO-PC. En aquesta pràctica el que farem serà calcular-los manualment (de forma molt simplificada).

A les dues pràctiques següents avaluarem l'eficàcia del tractament des de dues perspectives diferents, mitjançant el càlcul:

- del temps letal $99\left(\mathrm{TL}_{99}\right)$ d'una població de mosca de la fruita quan s'exposa a una quarantena per fred $\left(2^{\circ} \mathrm{C}\right)$,

- de la dosi letal $50\left(\mathrm{DL}_{50}\right)$ d'una població de mosca de la fruita quan s'exposa a diferents concentracions de sal comuna.

\section{Objectius de les pràctiques}

En les dues pràctiques següents avaluarem l'eficàcia d'un tractament des de les dues perspectives plantejades. En la primera pràctica calcularem el temps d'exposició letal $99\left(\mathrm{TL}_{99}\right)$ d'una població de larves de mosca mediterrània de la fruita fixant la temperatura de quarantena a $2^{\circ} \mathrm{C}$ i analitzant el seu efecte en el nombre d'adults obtinguts. En la segona pràctica determinarem la corba de toxicitat de la sal comuna $(\mathrm{NaCl})$, la dosi letal $50\left(\mathrm{DL}_{50}\right)$, sobre les larves de C. capitata. Utilitzarem la sal per evitar haver de manipular substàncies perilloses. En aquest cas exposarem larves de la mosca a dosis creixents de $\mathrm{NaCl}$, i n'avaluarem l'efecte sobre l'emergència d'adults.

\subsection{Quarantena per fred}

Per tant, els objectius d'aquesta primera pràctica es concreten en quatre:

1. Familiaritzar-se amb part de la cria d'un fitòfag important com és la mosca mediterrània de la fruita.

2. Entendre en què es basen les quarantenes.

3. Comprovar com la temperatura influeix directament en el desenvolupament dels insectes.

4. Aprendre a calcular de manera simplificada el temps letal i en concret el temps d'exposició letal $99\left(\mathrm{TL}_{99}\right)$. 


\subsection{Assaigs de toxicitat}

Els objectius de la segona pràctica són:

1. Familiaritzar-se amb part de la manipulació de plaguicides i les seues dosis.

2. Aprendre a calcular corbes de toxicitat.

3. Avaluar l'efecte d'un tòxic en una població d'un insecte i, específicament, la dosi letal $50\left(\mathrm{DL}_{50}\right)$.

\section{Desenvolupament de les pràctiques}

\subsection{Quarantena per fred}

\subsubsection{Material}

\section{Preparació de l'assaig}

El material necessari per dur a terme aquesta pràctica és:

- Colònia de Ceratitis capitata amb larves de segon estadi

- Dieta. Components (per a uns 1.000 ous: 4 ous/g):

- segó: 300 g

- sucre: $75 \mathrm{~g}$

- llevat de cervesa en pols: $38 \mathrm{~g}$

- àcid benzoic: $1 \mathrm{~g}$

- propilparabén: $3 \mathrm{~g}$

- metilparabén: $3 \mathrm{~g}$

- aigua destil·lada: $500 \mathrm{ml}$

- Balança

- Got de precipitats de vidre

- Mistera Bunsen

- Vara de vidre

- Plaques de Petri de $90 \mathrm{~mm}$ de diàmetre

- Pinzell

- Pinces entomològiques

- Espàtula

- Tela de muselina

- Gomes elàstiques

- Paper d'alumini

- Pots de vidre o plàstic d'un diàmetre superior a $90 \mathrm{~mm}$

- Lupa binocular

- Dues incubadores, una a $2^{\circ} \mathrm{C}$ i l'altra a $25^{\circ} \mathrm{C}$ 


\section{Càlcul del $\mathrm{TL}_{99}$}

El material necessari per calcular el TL manualment:

- Paper mil·limetrat

- Regle

- Llapis

- Calculadora

- Taula de conversió de mortalitat a pròbits

- Taula de distribució de la $\chi^{2}$

\subsubsection{Metodologia}

\section{Preparació de la dieta}

Abans de començar amb la manipulació de la mosca, hem de preparar la dieta. Els components sòlids de la dieta (a excepció de l'àcid benzoic) es donaran ja pesats i mesclats convenientment per a incorporar-los a la dieta. El segó és el substrat que suporta la resta de components i crea un ambient adequat per al desenvolupament larvari de $C$. capitata. El sucre proporciona hidrats de carboni i el llevat proteïnes. L'àcid benzoic, el propilparabén i el metilparabén són fungicides i bactericides. D'aquesta barreja en prendrem $75 \mathrm{~g}$ i els introduirem en un got de precipitats. Escalfarem l'aigua en un altre got de precipitats fins a portar-la a ebullició, moment en que apagarem el foc i afegirem l'àcid benzoic, que dissoldrem amb l'ajut d'una vareta, remenant-la contínuament per tal que l'àcid s'hi desfaça. Caldrà reajustar el volum per les possibles pèrdues en l'evaporació. Una volta obtinguda la dissolució, l'anirem afegint als components sòlids poc a poc i treballant la massa perquè quede homogènia. En el moment que tota la massa quede lligada i lleugerament humida, deixarem d'afegir-hi aigua. Finalment dividirem la dieta obtinguda en sis parts i anirem col-locant cada part en una placa de Petri (aproximadament 15 g/placa), i la hi deixarem ben compactada, ja que a les larves de la mosca, no els agrada que el substrat de cria quede poc compacte (figura 5).

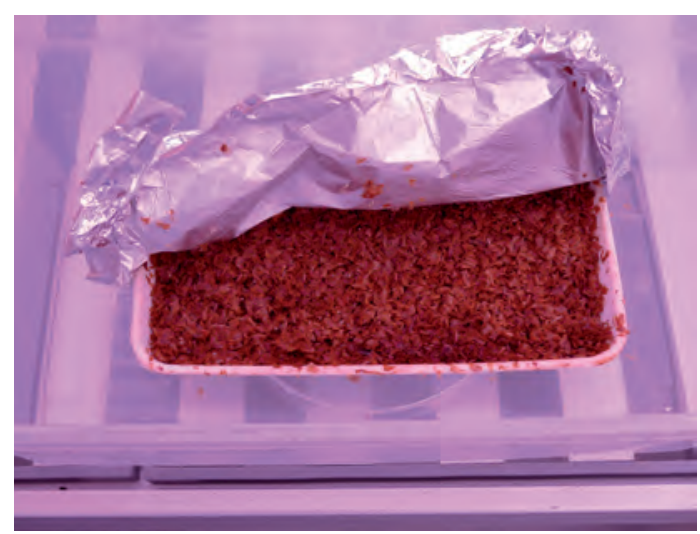

Figura 5. Aspecte de la dieta en una safata de cria de Ceratitis capitata 


\section{Desenvolupament de la pràctica}

A partir de la colònia de $C$. capitata mantinguda en l'insectari de la universitat, obtindrem larves de segon estadi (L2) de la mosca. Aquest estadi és el penúltim abans de pupar, i per tant es tracta de larves de mida mitjana (figura 6). Amb l'ajut de pinces i pinzells, anirem passant $10 \mathrm{~L} 2$ a les plaques de Petri (on prèviament ja havíem col-locat la dieta) amb molta cura per no danyar-les. Per afavorir la pupació, recobrirem les plaques amb paper d'alumini, ja que a les larves els agrada la foscor. A continuació, introduirem cada placa de Petri en un pot de plàstic o vidre, el qual es tancarà amb la tela de muselina i la goma elàstica. Aquestes plaques constituiran el material bàsic per determinar la tolerància de les L2 de C. capitata a temperatures baixes.
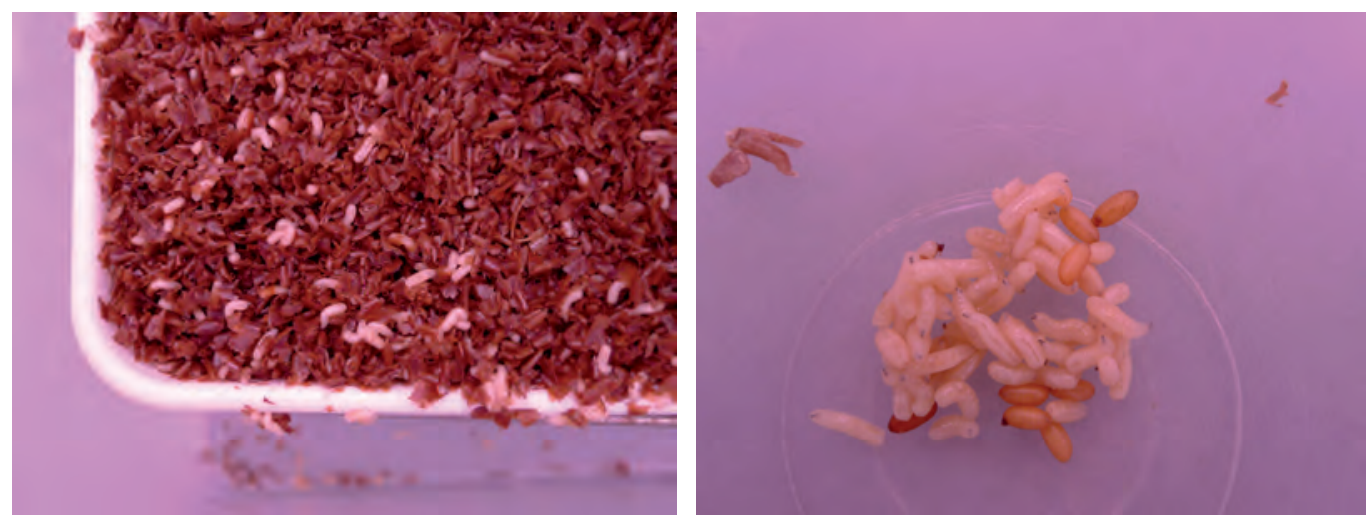

Figura 6. Dieta amb larves de Ceratitis capitata; larves del tercer estadi a punt de pupar (dreta)

Les plaques acabades de sembrar s'exposaran a la temperatura experimental de $2^{\circ} \mathrm{C}$ a l'interior d'una incubadora $\mathrm{i}$ les mantindrem a aquesta temperatura el temps determinat en cada cas, que serà variable en funció del grup de pràctiques i del dia. Transcorregut aquest temps a $2^{\circ} \mathrm{C}$, les introduirem en una nova estufa, aquesta vegada a $25^{\circ} \mathrm{C}$, per permetre que les supervivents continuen el seu desenvolupament normal. Al final de l'assaig comptarem el nombre de pupes i d'adults obtingut per a cadascun dels temps d'exposició, i en calcularem la mortalitat corresponent (figura 7).

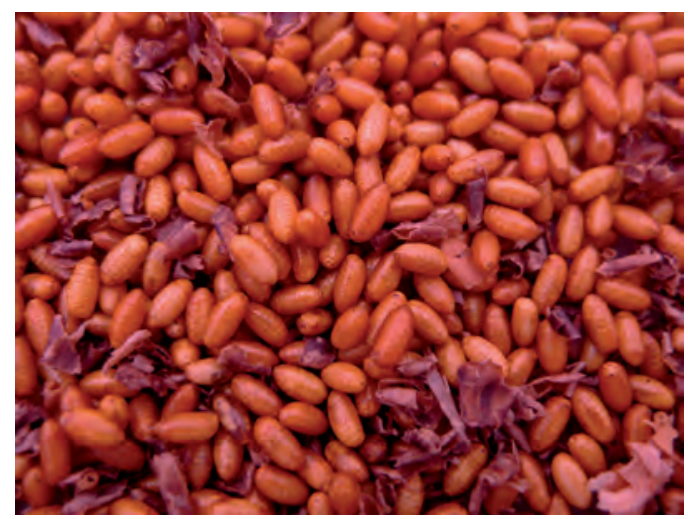

Figura 7. Pupes de Ceratitis capitata 
Desenvoluparem la pràctica al llarg de quatre setmanes. Durant la primera, sembrarem les plaques amb les L2. Les altres tres setmanes serviran perquè els insectes completen el seu cicle a $2^{\circ} \mathrm{C}$ i a $25^{\circ} \mathrm{C}$ i per fer l'avaluació de l'assaig.

Tots els grups sembraran les larves el primer dia de pràctiques. Com que hi ha diferents grups de pràctiques, encara que l'activitat de cada grup siga la mateixa, variaran els temps d'exposició a $2^{\circ} \mathrm{C}$, i per tant els resultats obtinguts per cada grup seran diferents i complementaris.

El primer dia de pràctiques formarem grups de 3-4 persones cadascun. Aquests grups prepararan 6 plaques de la manera indicada, de les quals una actuarà com a control i es deixarà al llarg de tot el temps a $25^{\circ} \mathrm{C}$, i les altres 5 es deixaran a $2^{\circ} \mathrm{C}$. En funció dels grups que hi haja, fixarem uns dies al calendari perquè cada grup canvie unes de les seus plaques des de la incubadora a $2^{\circ} \mathrm{C}$ a $25^{\circ} \mathrm{C}$. Procurarem que al final hi haja un nombre suficient de repeticions per a cada temps d'exposició (1-12 dies), d'on avaluarem la mortalitat de les larves.

Donat que el desenvolupament de les larves supervivents no es tornarà a iniciar fins que no les passem a $25^{\circ} \mathrm{C}$, des del moment en què acabe l'exposició a $2^{\circ} \mathrm{C}$ caldrà esperar d'una a dues setmanes fins que les pupes comencen a donar origen als adults. Passada aquesta setmana podrem començar a obrir les bosses i fer el recompte dels adults emergits.

Cada grup de persones anotarà els valors obtinguts del seu assaig a la taula $1, \mathrm{i}$ al final de tots els assajos s'ajuntaran totes les dades per calcular conjuntament la dosi letal.

\begin{tabular}{|l|c|c|c|}
\hline \multicolumn{5}{|c|}{ Valors a omplir per cada grup de pràctiques } \\
\hline \multicolumn{1}{|c|}{ Placa } & $\begin{array}{c}\text { Nre. individus total } \\
\text { inicial } \\
(\mathrm{Nt})\end{array}$ & $\begin{array}{c}\text { Nre. adults emergits } \\
(\mathrm{Ne})\end{array}$ & $\begin{array}{c}\text { Nre. individus morts } \\
(\mathrm{Nm}) \\
(\mathrm{Nm}=\mathrm{Nt}-\mathrm{Ne})\end{array}$ \\
\hline 1 (control) & & & \\
\hline 2 & & & \\
\hline 3 & & & \\
\hline 4 & & & \\
\hline 5 & & & \\
\hline 6 & & & \\
\hline
\end{tabular}

Taula 1. Resultat obtingut per cada grup. Cada placa (2-6) s'haurà sotmès a un tractament d'exposició diferent $\mathrm{i}$ constituirà una repetició.

En la taula 2 representada com a repetició $1-5$ 


\section{Càlcul de les eficàcies corregides}

Abans de passar a calcular el temps letal cal que calculem alguns paràmetres, com ara l'eficàcia corregida. Sovint ens trobem que sense sotmetre els insectes a cap tipus de tractament observem una mortalitat natural. Per això, quan volem calcular la mortalitat provocada per un tractament biocida (temperatura, plaguicides, etc.), acostumen a treballar amb mortalitats corregides o, com també s'anomena, percentatge de l'eficàcia corregida. El que fem és descomptar de la mortalitat observada, la mortalitat natural. L'eficàcia corregida es pot calcular mitjançant diverses fórmules en funció de si la població inicial és uniforme o no (les repeticions tenien el mateix nombre d'insectes?), o de si els valors de què disposem són individus vius o morts. Si acceptem que la nostra població és uniforme, podem emprar la fórmula d'Abbott (1925) quan avaluem organismes vius i la fórmula de SchneiderOrelli (Püntener, 1981) quan es tracte d'individus morts:

Segons Abbott:

Percentatge de l'eficàcia corregida $=(x-y / x) * 100$

Sent:

$\mathrm{x}=\%$ supervivència en el control

$\mathrm{y}=\%$ supervivència en el grup exposat al tractament

Segons Schneider-Orelli:

Percentatge de l'eficàcia corregida $=(x-y /(100-y)) * 100$

Sent:

$\mathrm{x}=\%$ mortalitat en el grup exposat al tractament

$\mathrm{y}=\%$ mortalitat en el control

La mortalitat del control serà la que s'obtinga de les plaques sotmeses únicament a $25^{\circ} \mathrm{C}$ durant tot l'assaig, i hauria de ser inferior al $20 \%$ per poder donar l'assaig per bo. Per al càlcul de l'eficàcia s'empra la mitjana dels valors del control i de cada tractament, tal com es mostra en les taules 2 i 3 .

\begin{tabular}{|l|c|c|c|c|}
\hline \multicolumn{5}{|c|}{ Temps d'exposició de 2 dies } \\
\hline Repeticions & $\begin{array}{c}\text { Nre. individus total } \\
(\mathrm{Nt})\end{array}$ & $\begin{array}{c}\text { Nre. adults emergits } \\
(\mathrm{Ne})\end{array}$ & $\begin{array}{c}\text { Nre. individus morts } \\
(\mathrm{Nm}) \\
(\mathrm{Nm}=\mathrm{Nt}-\mathrm{Ne})\end{array}$ & $\begin{array}{c}\% \text { mortalitat } \\
(\mathrm{Nm} / \mathrm{Nt}) * 100\end{array}$ \\
\hline 1 & & & & \\
\hline 2 & & & & \\
\hline 3 & & & & \\
\hline 4 & & & & \\
\hline 5 & & & & \\
\hline Mitjana & & & & \\
\hline
\end{tabular}

Taula 2. Exemple de com calcular el percentatge de mortalitat per a un temps d'exposició de, per exemple, 2 dies a $2^{\circ} \mathrm{C}$ 
Eficàcia del tractament (dies d'exposició a $2^{\circ} \mathrm{C}$ )

\begin{tabular}{|c|l|l|l|l|l|l|l|l|l|l|l|l|l|}
\hline $\begin{array}{c}\text { Temps d'exposició } \\
\text { (dies) }\end{array}$ & 0 & 1 & 2 & 3 & 4 & 5 & 6 & 7 & 8 & 9 & 10 & 11 & 12 \\
\hline $\begin{array}{c}\text { Mitjana } \\
\text { \% eficàcia } \\
\text { (Schneider-Orelli) }\end{array}$ & -- & & & & & & & & & & & & \\
\hline
\end{tabular}

Taula 3. Càlcul del percentatge d'eficàcia segons la fórmula de Schneider-Orelli. El temps d'exposició 0 es considera que és el control amb el qual calcularem el percentatge d'eficàcia

Amb el percentatge de l'eficàcia (taula 3) elaborarem una gràfica on representarem la mortalitat de les $\mathrm{L} 2$ respecte al temps d'exposició.

\section{Transformació a pròbits i càlcul del $\mathrm{TL}_{99}$}

Per transformar aquesta gràfica en una recta lineal cal transformar el tractament (dies d'exposició) a logaritme de base 10 i la mortalitat corregida a pròbits (transformació log-pròbit) (taula 4). Els pròbits es calcularan amb la taula pròbit que mostra la transformació del percentatge de mortalitat a pròbits (taula 5).

\begin{tabular}{|c|c|c|c|c|c|c|c|c|c|c|c|c|c|}
\hline \multicolumn{10}{|c|}{ Transformació log-pròbit } \\
\hline $\begin{array}{c}\text { Temps d'exposició } \\
\text { (dies) }\end{array}$ & 0 & 1 & 2 & 3 & 4 & 5 & 6 & 7 & 8 & 9 & 10 & 11 & 12 \\
\hline $\begin{array}{c}\text { \% eficàcia } \\
\text { (mortalitat) }\end{array}$ & -- & & & & & & & & & & & & \\
\hline $\begin{array}{c}\text { Logaritme dels } \\
\text { dies d'exposició }\end{array}$ & -- & & & & & & & & & & & & \\
\hline Pròbits empírics & -- & & & & & & & & & & & & \\
\hline
\end{tabular}

Taula 4. Transformació logarítmica del tractament (dies d'exposició) i càlcul dels pròbits amb la mortalitat corregida per a cada temps d'exposició 


\begin{tabular}{llllllllll}
\hline$\%$ & \multicolumn{3}{c}{$\%$} & \multicolumn{3}{c}{$\%$} & $\%$ & \multicolumn{3}{c}{$\%$} \\
\hline & & & & & & & & & \\
0 & & 20 & 4,1584 & 40 & 4,7467 & 60 & 5,2533 & 80 & 5,8416 \\
1 & 2,6737 & 21 & 4,1936 & 41 & 4,7725 & 61 & 5,2793 & 81 & 5,8779 \\
2 & 2,9463 & 22 & 4,2278 & 42 & 4,7981 & 62 & 5,3055 & 82 & 5,9154 \\
3 & 3,1192 & 23 & 4,2612 & 43 & 4,8236 & 63 & 5,3319 & 83 & 5,9542 \\
4 & 3,2493 & 24 & 4,2937 & 44 & 4,8490 & 64 & 5,3585 & 84 & 5,9945 \\
& & & & & & & & & \\
5 & 3,3551 & 25 & 4,3255 & 45 & 4,8743 & 65 & 5,3853 & 85 & 6,0364 \\
6 & 3,4452 & 26 & 4,3567 & 46 & 4,8996 & 66 & 5,4125 & 86 & 6,0803 \\
7 & 3,5242 & 27 & 4,3872 & 47 & 4,9247 & 67 & 5,4399 & 87 & 6,1264 \\
8 & 3,5949 & 28 & 4,4172 & 48 & 4,9498 & 68 & 5,4677 & 88 & 6,1750 \\
9 & 3,6592 & 29 & 4,4466 & 49 & 4,9749 & 69 & 5,4959 & 89 & 6,2265 \\
& & & & & & & & & \\
10 & 3,7184 & 30 & 4,4756 & 50 & 5,0000 & 70 & 5,5244 & 90 & 6,2816 \\
11 & 3,7735 & 31 & 4,5041 & 51 & 5,0251 & 71 & 5,5534 & 91 & 6,3408 \\
12 & 3,8250 & 32 & 4,5323 & 52 & 5,0502 & 72 & 5,5828 & 92 & 6,4051 \\
13 & 3,8736 & 33 & 4,5601 & 53 & 5,0753 & 73 & 5,6128 & 93 & 6,4758 \\
14 & 3,9197 & 34 & 4,5875 & 54 & 5,1004 & 74 & 5,6433 & 94 & 6,5548 \\
& & & & & & & & & \\
15 & 3,9636 & 35 & 4,6147 & 55 & 5,1257 & 75 & 5,6745 & 95 & 6,6449 \\
16 & 4,0055 & 36 & 4,6415 & 56 & 5,1510 & 76 & 5,7063 & 96 & 6,7507 \\
17 & 4,0458 & 37 & 4,6681 & 57 & 5,1764 & 77 & 5,7388 & 97 & 6,8808 \\
18 & 4,0846 & 38 & 4,6945 & 58 & 5,2019 & 78 & 5,7722 & 98 & 7,0537 \\
19 & 4,1221 & 39 & 4,7207 & 59 & 5,2275 & 79 & 5,8064 & 99 & 7,3263 \\
\hline
\end{tabular}

Taula 5. Transformació dels percentatges de mortalitat a pròbits

\section{Càlcul manual del $\mathrm{TL}_{99}$}

A partir d'aquestes dades elaborarem una gràfica en paper mil-limetrat on representarem en l'eix de les abscisses el logaritme del temps d'exposició i en les ordenades el valor del pròbit empíric calculat amb les taules (dades color salmó en la taula 4), i ajustarem una recta a partir d'aquests punts. Després traçarem una línia horitzontal des del pròbit 5,0 fins que talle la recta que hem dibuixat. Des d'aquest punt dibuixarem una recta vertical que talle l'eix de les $x$. L'antilogaritme del valor de tall en el eix de les abscisses és el $\mathrm{TL}_{50}$, es a dir al temps que cal que estiguen exposades al fred les L2 de C. capitata perquè mora el $50 \%$ de la població. Ja que el que busquem és la $\mathrm{DL}_{99}$, traçarem una recta des del pròbit 9 fins tallar la recta dibuixada i l'antilogaritme del valor de tall de les $x$ serà el temps que caldrà que estiguen exposades al fred les L2 perquè la nostra quarantena experimental siga efectiva.

En la pràctica, el que farem per tal d'aplicar aquest resultat a un cas real, serà prendre un marge de seguretat prou ample, que assegure la total destrucció de l'insecte en les fruites i verdures $\left(2 \times \mathrm{TL}_{99}\right.$, per exemple), sempre que aquesta exposició no resulte en danys inacceptables (organolèpticament) en la fruita tractada. 
L'equació de la recta hauria d'anar acompanyada dels límits fiducials i de la bondat de l'ajustament de les dades. Aquests valors es poden calcular manualment si bé, atès que és complicar el càlcul, ens aturarem en aquest punt amb les nostres dades. Si emprarem un programa informàtic, junt a les dades relatives a la recta de regressió obtinguda $(y=a+b * \lg (x))$, apareixeria la bondat d'ajustament (prova de la $\chi^{2}$ ) i les dades dels diferents temps letals amb els seus límits fiducials al 95\%.

Per analitzar l'associació entre el temps d'exposició a la temperatura de quarantena i la mortalitat s'empra la prova d'hipòtesis de la $\chi^{2}$. Aquesta prova s'utilitza per determinar com s'ajusta la recta de regressió a les dades observades, de manera que una $\chi^{2}$ significativa podria indicar que les dades són heterogènies i que per tant haurien de ser corregides mitjançant un factor de heterogeneïtat, o que seria més adequat per a les dades una transformació alternativa (Throne et al., 1995b).

Per saber si és significativa o no la $\chi^{2}$ es mira en la taula de distribució de valors de $\chi^{2}$ (taula 6) a quina probabilitat correspon el valor obtingut de $\chi^{2}$ en funció dels graus de llibertat. Si aquesta probabilitat és superior a 0,05 voldrà dir que la recta s'ajusta bé al model, mentre que si la probabilitat és inferior a 0,05 significarà que la recta no s'ajusta bé al model, i per tant caldrà buscar altres transformacions.

A classe es mostraran diferents exemples d'eixides generades pel programa POLOPC per practicar amb la taula de distribució de valors $\chi^{2}$ i conèixer l'ajustament de les rectes generades de les dades observades. 


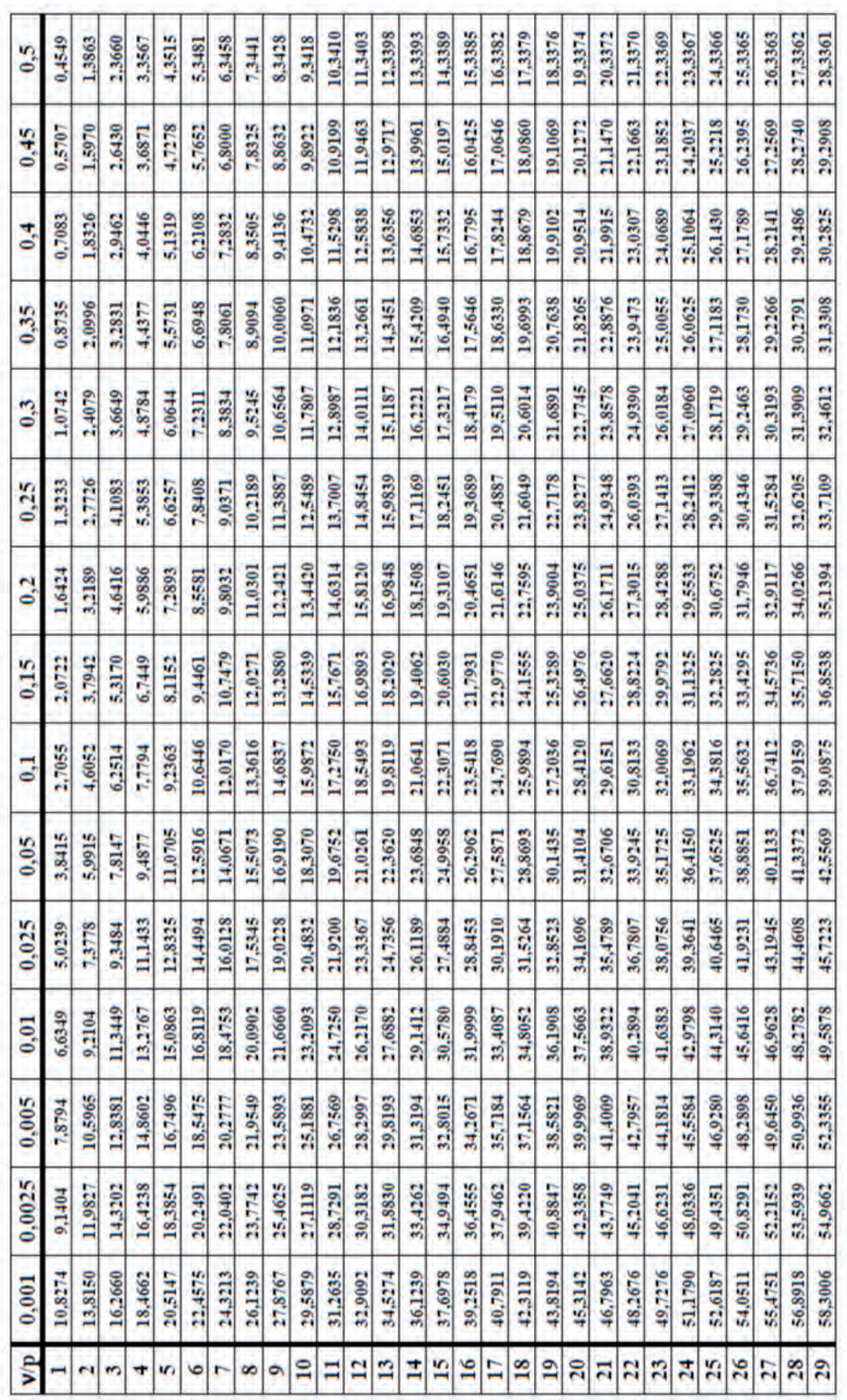




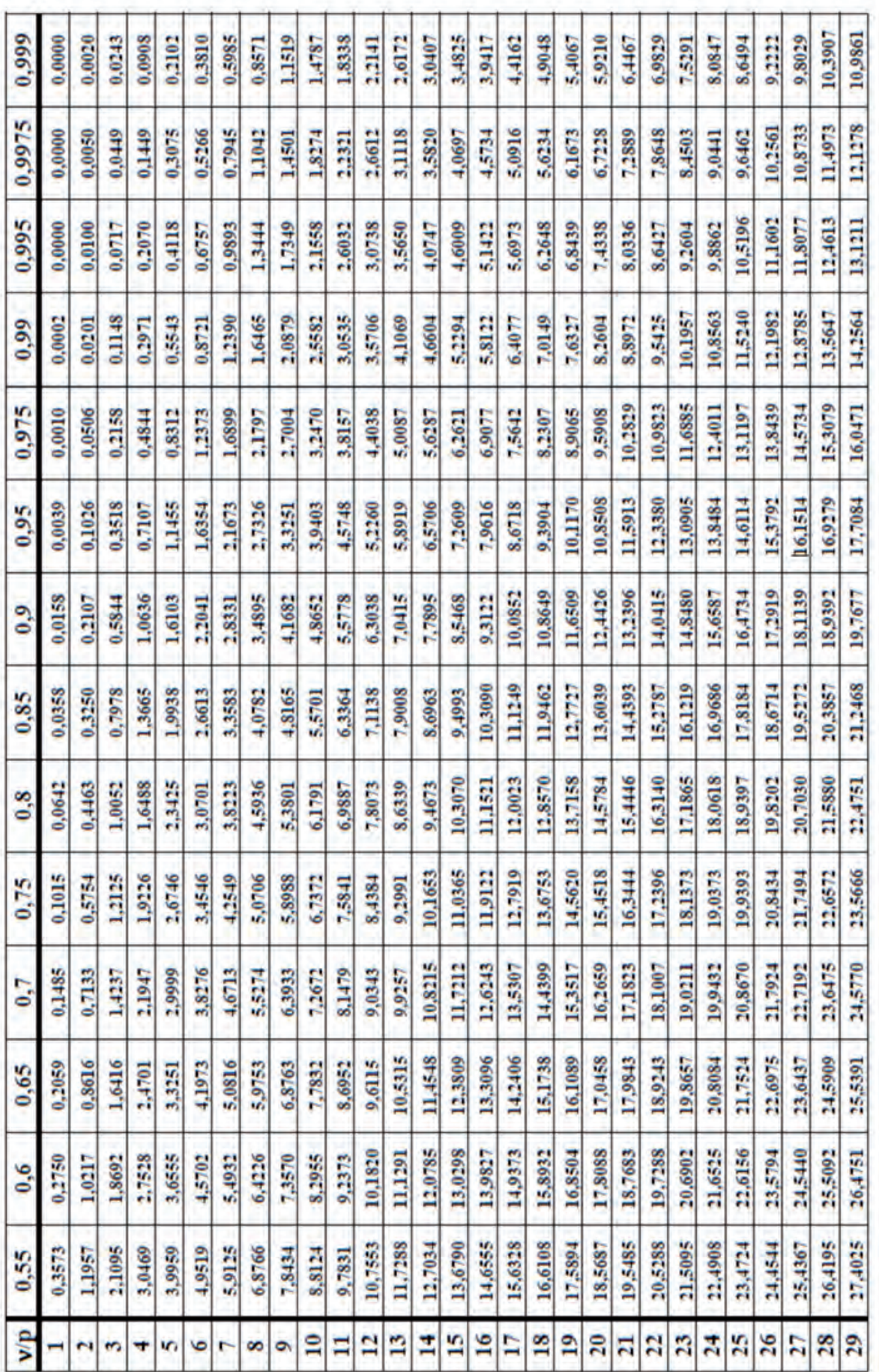

Taula 6. Taula de distribució de $\chi^{2}$ on $v$ són els graus de llibertat i $P$ és la probabilitat de trobar un valor més alt o igual que el $\chi^{2}$ tabulat 


\subsection{Assaigs de toxicitat}

\subsubsection{Material}

\section{Preparació de l'assaig}

El material necessari per dur a terme aquesta pràctica és:

- Colònia de Ceratitis capitata amb larves de segon estadi

- Dieta. Components (per a uns 1.000 ous: 4 ous/g):

- segó: 300 g

- sucre: $75 \mathrm{~g}$

- llevat de cervesa en pols: $38 \mathrm{~g}$

- àcid benzoic: $1 \mathrm{~g}$

- propilparabén: $3 \mathrm{~g}$

- metilparabén: $3 \mathrm{~g}$

- aigua destil·lada: $500 \mathrm{ml}$

- Sal de cuina $(\mathrm{NaCl})$

- Balança

- Gots de precipitat de vidre

- Mistera Bunsen

- Vara de vidre

- Plaques de Petri de $90 \mathrm{~mm}$ i de $150 \mathrm{~mm}$ de diàmetre

- Pinzell

- Pinces entomològiques

- Espàtula

- Tela de muselina

- Gomes elàstiques

- Paper d'alumini

- Pots de vidre o plàstic d'un diàmetre superior a $90 \mathrm{~mm}$

- Lupa binocular

- Una incubadora a $25^{\circ} \mathrm{C}$

\section{Càlcul del $\mathbf{T L}_{50}$}

El material necessari per calcular el TL manualment:

- Paper mil-limetrat

- Regle

- Llapis

- Calculadora

- Taula de conversió de mortalitat a pròbits

- Taula de distribució de la $\chi^{2}$ 


\subsubsection{Metodologia}

\section{Preparació de la dieta}

Abans de començar amb la manipulació de la mosca, cal que preparem la dieta amb les concentracions del tòxic que volem avaluar. Els components sòlids de la dieta (a excepció de l'àcid benzoic) es donaran ja pesats i mesclats convenientment per a la seua incorporació en la dieta. El segó és el substrat que suporta la resta de components i crea un ambient adequat per al desenvolupament larvari de la mosca mediterrània de la fruita. El sucre proporciona hidrats de carboni i el llevat proteïnes. L'àcid benzoic, el propilparabén i el metilparabén són fungicides i bactericides.

D'aquesta barreja en prendrem $300 \mathrm{~g}$ i els repartirem entre 5 plaques de Petri grans (60 g per placa). En quatre de les cinc plaques afegirem la sal prèviament pesada a una concentració creixent de $25 \mathrm{~g} / \mathrm{kg}, 100 \mathrm{~g} / \mathrm{kg}, 250 \mathrm{~g} / \mathrm{kg}$ i $500 \mathrm{~g} / \mathrm{kg}$, i que equivaldrà a 1,5 g, 6 g, 15 g i 30 g, respectivament. En la quinta placa no afegirem sal i serà la que emprem com a control.

Escalfarem l'aigua en un got de precipitats fins a portar-la a ebullició, moment en què apagarem el foc $\mathrm{i}$ hi afegirem l'àcid benzoic, que es dissoldrà amb l'ajut d'una vareta que remenarem contínuament per tal que l'àcid s'hi desfaça. Caldrà reajustar el volum per les possibles pèrdues en l'evaporació. Una volta obtinguda la dissolució, l'anirem afegint als components sòlids poc a poc i treballant la massa perquè quede homogènia i no es vegen cristalls de sal. En el moment que tota la massa quede lligada i lleugerament humida, deixarem d'afegir-hi aigua. Posteriorment, el contingut de cadascuna d'aquestes 5 plaques el repartirem entre tres de $9 \mathrm{~cm}$, que constituiran les tres repeticions de cada tractament. Procurarem que la dieta quede ben compactada, ja que a les larves de la mosca no els agrada que el substrat de cria estiga poc compacte. En cada placa retolarem la concentració de sal que conté, el número de rèplica de què es tracta $\mathrm{i}$ el nom dels components del grup.

\section{Desenvolupament de la pràctica}

Amb la dieta ja distribuïda, afegirem, amb molta cura per no danyar-les, 20 larves de segon estadi a cada placa amb l'ajut de pinces i pinzell. Les plaques les recobrirem a continuació amb paper d'alumini, les introduirem individualment en els pots de plàstic o vidre i les tancarem amb tela de muselina i una goma elàstica per tal d'evitar que les larves saltadores de l'últim estadi s'escapen. Aquestes plaques constituiran el material bàsic per determinar la $\mathrm{DL}_{50}$.

Mantindrem les plaques en una incubadora a $25^{\circ} \mathrm{C}$ fins que en fem la inspecció 15 dies després. En aquell moment, caldrà obrir els pots i comptar el nombre de pupes i d'adults emergits. Les mortalitats observades caldrà corregir-les amb la mortalitat del control, segons la fórmula de Schneider-Orelli, tal com s'ha vist prèviament. En aquest cas afegirem els valors a la taula 7. Per al càlcul de l'eficàcia emprarem la mitjana dels valors del control i de cada tractament. 


\begin{tabular}{|c|c|c|c|c|c|}
\hline Tractaments & $\begin{array}{l}\text { Nre. individus } \\
\text { total inicial } \\
\text { (Nt) }\end{array}$ & $\begin{array}{l}\text { Nre. adults } \\
\text { emergits } \\
(\mathrm{Ne})\end{array}$ & $\begin{array}{l}\text { Nre. individus } \\
\text { morts }(\mathrm{Nm}) \\
(\mathrm{Nm}=\mathrm{Nt}-\mathrm{Ne})\end{array}$ & $\begin{array}{c}\% \text { mortalitat } \\
(\mathrm{Nm} / \mathrm{Nt}) * 100\end{array}$ & $\begin{array}{c}\text { Percentatge } \\
\text { d'eficàcia } \\
\text { (Schneider- } \\
\text { Orelli) }\end{array}$ \\
\hline \multicolumn{6}{|l|}{ Control - 1} \\
\hline \multicolumn{6}{|l|}{ Control - 2} \\
\hline \multicolumn{6}{|l|}{ Control - 3} \\
\hline Mitjana & & & & & - \\
\hline & & & & & \\
\hline \multicolumn{6}{|l|}{$25-1$} \\
\hline \multicolumn{6}{|l|}{$25-2$} \\
\hline \multicolumn{6}{|l|}{$25-3$} \\
\hline \multicolumn{6}{|l|}{ Mitjana } \\
\hline & & & & & \\
\hline \multicolumn{6}{|l|}{$100-1$} \\
\hline \multicolumn{6}{|l|}{$100-2$} \\
\hline \multicolumn{6}{|l|}{$100-3$} \\
\hline \multicolumn{6}{|l|}{ Mitjana } \\
\hline & & & & & \\
\hline \multicolumn{6}{|l|}{$250-1$} \\
\hline \multicolumn{6}{|l|}{$250-2$} \\
\hline \multicolumn{6}{|l|}{$250-3$} \\
\hline \multicolumn{6}{|l|}{ Mitjana } \\
\hline \multicolumn{6}{|l|}{$500-1$} \\
\hline \multicolumn{6}{|l|}{$500-2$} \\
\hline \multicolumn{6}{|l|}{$500-3$} \\
\hline Mitjana & & & & & \\
\hline
\end{tabular}

Taula 7. Càlcul de l'eficàcia corregida de quatre tractaments (amb tres repeticions) amb diferents concentracions de sal comuna. Amb la mitjana del percentatge de mortalitat (requadre taronja) es calcularia el percentatge d'eficàcia del tractament (requadre en verd)

En la representació manual, en lloc de calcular el logaritme del temps d'exposició, es calcularà el logaritme de la concentració emprada, i l'antilogaritme del valor de tall que obtinguem en l'eix de les abscisses per al pròbit 5 serà la dosi necessària per matar el $50 \%$ de la població $\left(\mathrm{DL}_{50}\right)$ de larves de segon estadi de $C$. capitata. 


\section{PRÀCTICA 6}

\section{Utilització d'un model en protecció vegetal: Lateblight, per al míldiu de la creilla, Phytophthora infestans (Mont.) de Bary (Oomycota: Pythiaceae)}

\section{Antecedents}

\subsection{Phytophthora infestans (Mont.) de Bary}

L'oomicet Phytophthora infestans és un agent patogen que ataca diverses espècies de la família de les solanàcies, especialment la creïlla (Solanum tuberosum L.) i la tomaca (Lycopersicon esculentum Miller), així com algunes d'ornamentals, causant-los una malaltia del grup dels míldius coneguda com a míldiu de la patata o de la creïlla. Aquesta malaltia és una de les més importants del cultiu de la creïlla a nivell mundial; de fet, el seu nom deriva del vocable grec phyto, 'planta' i phthora, 'destructor'. En anglès es coneix com a late blight, 'plaga tardana', perquè normalment apareix al final de l'estació, durant els períodes més humits.

Aquest cromista que pertany al fílum Oomycota, ordre Pythiales i família Pythiaceae, es va agrupar en un inici amb els fongs gràcies a les seues formes filamentoses, semblants a les hifes, i a la seua alimentació de matèria en descomposició. Tanmateix, la paret dels oomicets no està formada per quitina, com la dels fongs veritables, sinó per cel-lulosa, polímers semblants i glicans. Per altra banda, els nuclis dins del filaments són sempre diploides, a diferència dels fongs, que presenten alternances haploide/diploide/dicariont. Les espores lliures que produeixen (zoòspores) es caracteritzen pel fet de tenir dos flagels asimètrics. Els oomicets són d'hàbits aquàtics i terrestres, encara que sempre necessiten la presència d'aigua líquida per iniciar una nova infecció.

Aquest oomicet pot aparèixer en qualsevol lloc on es troben els seus hostes, i és de ràpida dispersió sota determinades condicions climàtiques. A Irlanda, en una sola setmana de l'estiu de 1846, va destruir pràcticament tota la collita de creïlla, en un país on aquest tubercle era la principal font d'aliment, i donà lloc al que es coneix com la gran fam irlandesa, que va provocar la migració cap a altres països (especialment els EUA) d'una part molt gran de la població, tant irlandesa com de tot el nord d'Europa.

Per altra banda, aquest míldiu va ser la primera malaltia de plantes on es va poder demostrar que un microorganisme n'era l'agent causal, cosa que donà lloc a l'aparició de la patologia vegetal com una nova branca de la ciència (Schumann i D’Arcy, 2000). 


\subsection{Simptomatologia}

El míldiu de la creïlla i de la tomaca pot afectar totes les parts aèries de la planta. A les fulles, el símptoma típic és l'aparició d'unes lesions menudes, de color verd pàl-lid a fosc, d'aspecte oliós i de forma irregular, voltades d'un halo de color groguenc (figura 1). En condicions adequades de temperatura i humitat (períodes llargs d'humitat relativa per damunt del $90 \%$ i temperatures entre $20^{\circ} \mathrm{C}$ i $24^{\circ} \mathrm{C}$ ), aquestes lesions s'estenen ràpidament i s'enfosqueixen a mesura que el teixit afectat es va necrosant. Si la humitat és suficient, el fong comença a produir esporangis abundosament i es pot observar la massa blanquinosa formada pels esporangiòfors a la perifèria d'aquestes lesions, sobretot a la cara inferior de les fulles. Als ulls i als pecíols de la planta es pot detectar el mateix tipus de lesions fosques on el fong també pot acabar produint esporangis. La mort de la planta pot esdevenir dies després de la detecció de les primeres lesions.

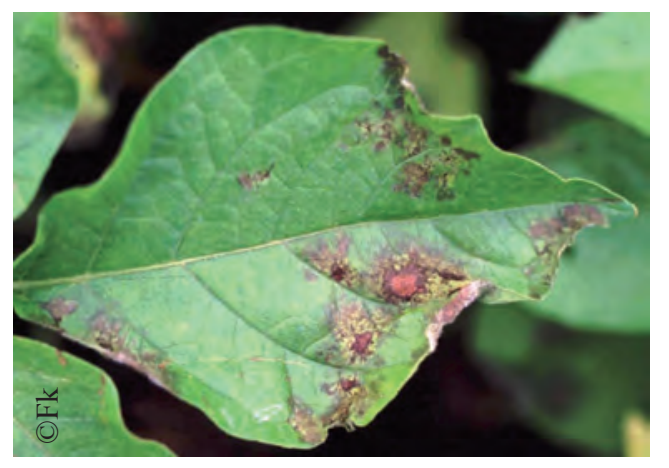

Figura 1. Danys de Phytophthora infestans en la fulla

Els tubercles, que es poden haver infectat bé per contacte amb les fulles atacades durant la recol·lecció, bé per zoòspores transportades per la pluja o per l'aigua de reg, mostren unes taques fosques, dures, de color marronós, rogenc o porpra, que poden acabar penetrant a l'interior, afectant un gruix de fins a més d'un centímetre del teixit del tubercle (figura 2). Secundàriament, els tubercles afectats, acaben colonitzats per bacteris productors de podrits molls (Pseudomonas spp., per exemple) $i$ es perden.

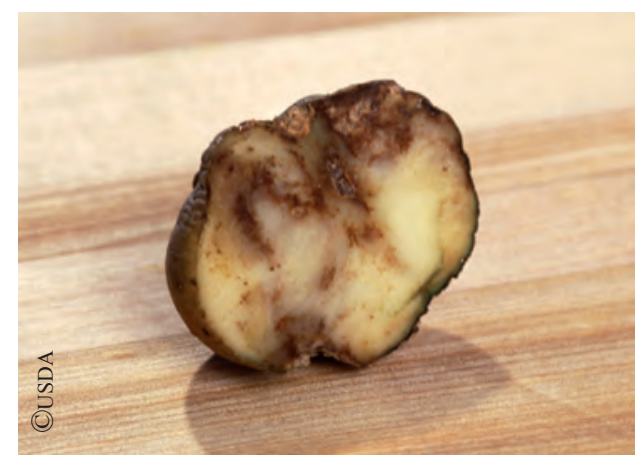

Figura 2. Danys de Phytophthora infestans a l'interior de la creilla 


\subsection{Biologia}

L'oomicet Phytophthora infestans es pot reproduir tant asexualment com sexualment en funció de les condicions climàtiques (figura 3).

La reproducció asexual és mitjançant els esporangis produïts en els esporangiòfors on la forma de bastonet ajuda en la dispersió aèria de l'esporangi. Quan les condicions climàtiques són càlides, els esporangis funcionen com una espora i germinen mitjançant el tub germinal infectant directament la planta. Per contra, en períodes humits i frescos, a l'interior dels esporangis es formen les zoòspores, amb dos flagels asimètrics que n'emergeixen, recorren la planta i la infecten.

La reproducció sexual només es produeix quan existeixen les formes compatibles d'anteridi i oogoni, els dos tipus d'aparellament A1 i A2, i aquests entren en contacte. D'aquesta manera, el nucli de l'anteridi penetra l'oogoni on, gràcies a la fusió dels dos nuclis, es forma l'oòspora diploide que posteriorment donarà lloc a l'esporangi (Schumann i D'Arcy, 2000).

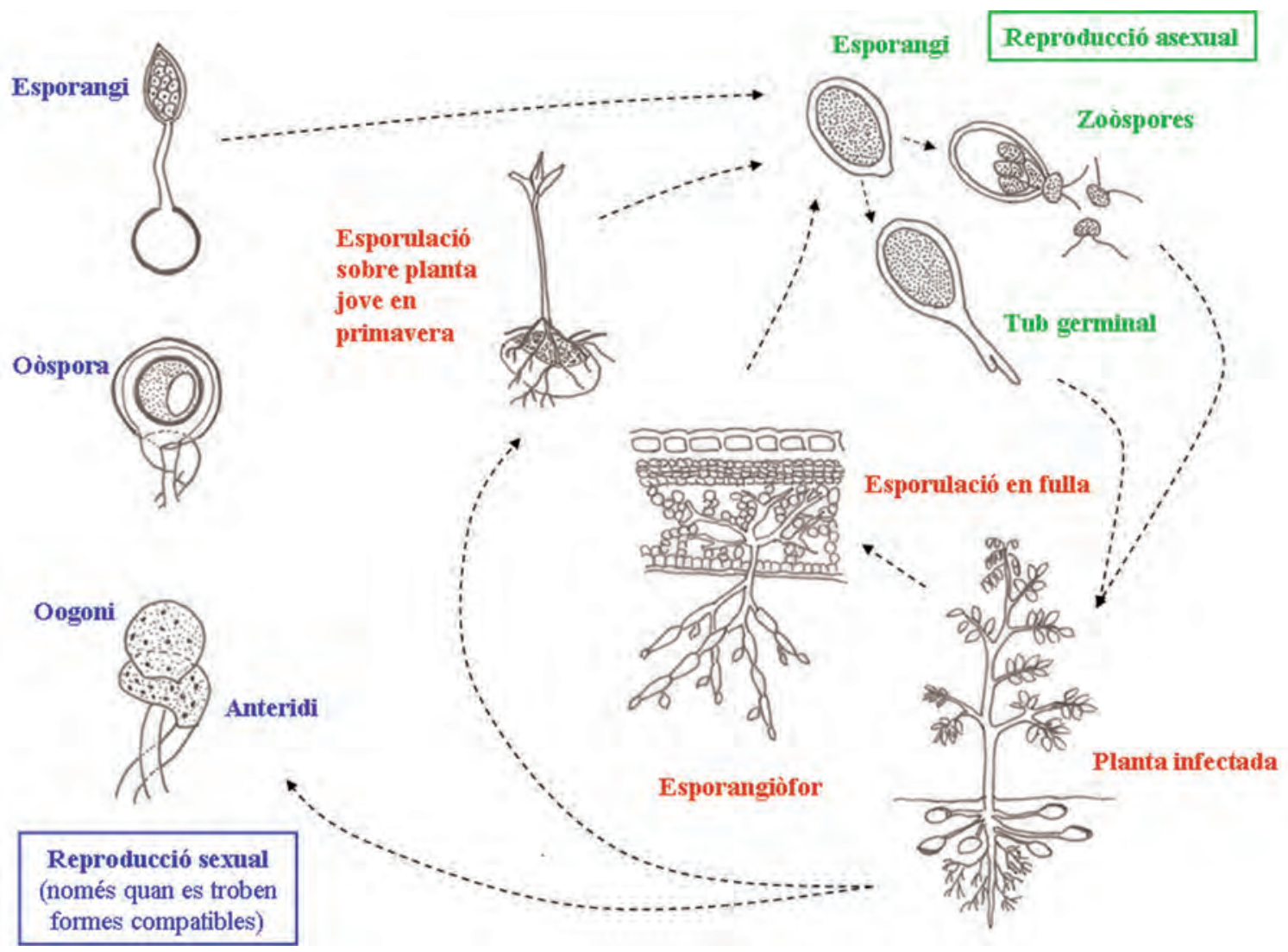

Figura 3. Cicle sexual i asexual del patogen Phytophthora infestans.

Adaptat de Schumann i D'Arcy, 2000 


\subsection{Epidemiologia}

Al nostre continent, el míldiu de la creïlla pot hivernar en forma de miceli sobre diferents tipus de teixit viu:

a) en tubercles infectats destinats a sembra,

b) en tubercles infectats en piles de rebuig,

c) en plantes aïllades que han quedat al camp com a resta d'un cultiu anterior,

d) en males herbes emparentades taxonòmicament (per exemple, les tomatetes, Solanum nigrum), o

e) en camps adjacents de tomaca, creïlla, pebrera o albergínia infectats.

La importància de cadascuna d'aquestes formes d'hibernació és variable segons la zona on ens trobem. Al Regne Unit, per exemple, es considera que les piles de creïlles rebutjades, on el creixement del miceli i la producció d'esporangis poden ser extraordinàriament ràpids $\mathrm{i}$ primerencs, tenen molta més importància com $\mathrm{a}$ inòcul primari que les creïlles de sembra.

Els brots malalts que poden produir els tubercles infectats no solen arribar a emergir per damunt del nivell de sòl, però poden servir per infectar per contacte directe fulles i tiges joves. És en aquest tipus de teixit on solem trobar els focus inicials de la malaltia al principi del cultiu. Normalment, el fong sobreviu en lesions de la tija, o a les axil·les foliars on, per la major retenció d'aigua que s'hi produeix, el fong pot mantenir-se en períodes secs i desfavorables. Però només quan la humitat relativa és molt alta (per damunt del 90\%), el fong comença a créixer i a produir esporangis en abundància. Una volta formats els esporangis, la seua disseminació progressa encara que la humitat disminuïsca, i poden estendre la malaltia fins a molts quilòmetres de distància del focus inicial. Aquests esporangis són els que o bé directament, o bé passant a formar zoòspores, produiran les infeccions secundàries en penetrar les cèllules epidèrmiques o els estomes mitjançant els tubs germinatius. L'interval òptim d'esporulació és entre els $18^{\circ} \mathrm{C}$ i els $22^{\circ} \mathrm{C}$, però pot donar-se entre els $3^{\circ} \mathrm{C}$ i els $26^{\circ} \mathrm{C}$. L'esporangi pot germinar directament entre els $21^{\circ} \mathrm{C}$ i els $26^{\circ} \mathrm{C}$, mentre que per sota dels $18^{\circ} \mathrm{C}$ la infecció és mitjançant zoòspores, les quals requereixen un medi aquós per moure's (Schumann i D'Arcy, 2000).

En condicions òptimes de temperatura i humitat com són les nits fresques, els dies càlids i l'ambient humit per boira o per pluja, una infecció primària que afecte tan sols 1'1\% de la superfície foliar d'una planta de creïlla amb bon creixement pot arribar a produir 4,5 milions d'esporangis, la qual cosa garanteix la dispersió de la malaltia als cultius del voltant i la destrucció, en menys de dues setmanes, de camps sencers de cultiu.

Només quan les condicions climàtiques canvien cap a un temps sec i assolellat, la infecció a altres plantes pot quedar aturada, ja que els esporangis han d'estar turgents per poder germinar. Aquesta turgència, només la poden aconseguir quan les fulles del cultiu romanen mullades durant, almenys, 15 hores seguides, de manera que els esporangis puguen absorbir l'aigua necessària. 
Aquesta relació entre les condicions climàtiques i el desenvolupament de la malaltia ha permès el desenvolupament de models que poden calcular la probabilitat d'atac en funció de les condicions climàtiques. Aquests models s'utilitzen en condicions de camp per determinar el risc d'infecció i, per tant, la conveniència d'aplicar algun tractament químic per al control de la malaltia.

A la figura 4 es representa la relació entre la durada dels períodes amb humitat relativa superior al 90\% i la temperatura mitjana, amb la probabilitat d'infecció de míldiu. Els valors de gravetat diaris (DSv, de l'anglès Daily Severity Values) són unitats arbitràries que corresponen a la probabilitat d'infecció, i s'utilitzen per recomanar tractaments químics al programa BLITECAST (MacKenzie, 1981).

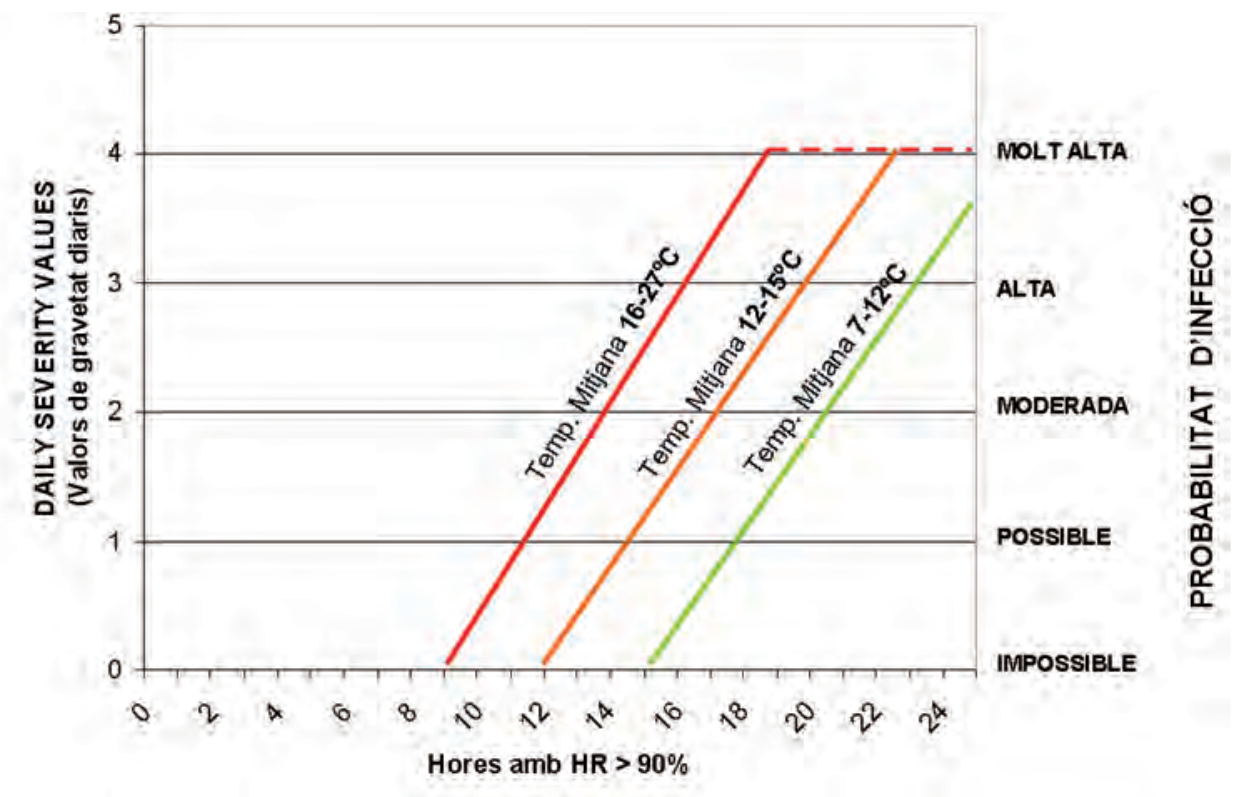

Figura 4. Relació entre la durada dels períodes amb humitat relativa superior al $90 \%$ i la temperatura mitjana, amb la probabilitat d'infecció de míldiu

\subsection{Control de la malaltia}

El control de la malaltia passa pel seguiment d'una sèrie de mesures agronòmiques tant a l'inici de la sembra com una vegada s'ha establert el cultiu. Les mesures recomanables abans de plantar la creïlla són les següents:

a) Emprar varietats resistents (encara que no hi ha cap varietat resistent a totes les soques de $P$. infestans).

b) Utilitzar creïlla de sembra certificada.

c) No plantar massa profund.

d) Marc de plantació no massa dens.

e) Assegurar un bon drenatge en el terreny.

f) Evitar la vegetació densa al voltant del cultiu per facilitar-ne una bona ventilació.

g) Rotació de cultius cada dos o tres anys amb plantes no hoste. 
h) Eliminar qualsevol possible inòcul inicial, ja siguen restes de tubercles, plantes aïllades o males brosses susceptibles de ser portadores d'oòspores.

Una vegada el cultiu ja està instal·lat, el control de la malaltia passa per:

a) Regar en dies assolellats, i si es rega per aspersió fer-ho al matí per tal que les fulles tinguen temps d'eixugar-se durant el dia.

b) Ús racional de l'adob nitrogenat per evitar creixements accelerats.

c) Fer prospeccions continuades per detectar l'aparició de les primeres taques, ja que les condicions d'humitat perllongades afavoreixen l'expansió d'aquest fong.

d) En zones on generalment apareixen atacs de míldiu, fer aplicacions de fungicides de manera preventiva quan les condicions siguen favorables. Repetir els tractaments cada 7-10 dies, i fins i tot més sovint si l'oratge és plujós i fresc. En aquest cas, també es disposa de fungicides sistèmics, que poden aplicar-se sols o en combinació, amb bons resultats.

e) En zones on els atacs són esporàdics només es recomana el tractament quan es vegen lesions en el camp o en cultius propers.

f) Quan s'aplique control químic, és important alternar fungicides pertanyents a diferents famílies per tal d'evitar problemes de resistència, que es coneixen en aquest fong.

g) Per tal de reduir la infecció dels tubercles durant la recol·lecció, es recomana dessecar la planta almenys 14 dies abans, ja que aquest fong no és capaç de sobreviure en teixit mort.

h) Eliminar qualsevol tubercle afectat abans d'emmagatzemar-lo, ja que estendria la malaltia en condicions de magatzem.

\subsection{El model}

El desenvolupament del míldiu de la creïlla ha estat estudiat amb profusió, i bona part dels resultats generats s'han utilitzat en epidemiologia analítica. Aquest treball ha permès obtenir sistemes de predicció com el Lateblight, que és el programa que utilitzarem en aquesta pràctica. Aquest programa es troba en l'aula virtual, però també està accessible en la pàgina web: http://www.scientificsocieties.org/ APS/late_blight/default.htm. Aquest programa ha sigut adaptat -de la simulació original escrita per Bruhn et al. (1980)- pel grup de W. E. Fry, del Departament de Patologia Vegetal de la Universitat de Cornell, (Fry et al., 1990) i posteriorment per Phil A. Arneson (Arneson, 2005), qui ha provat de fer-lo el més pedagògic possible. En aquesta pàgina web, a més de l'explicació, n'existeix un bon resum i una interessant proposta d'exercicis per comprendre el problema que suposa aquesta malaltia i quines estratègies de control es poden prendre per combatre-la (Arneson, 2005).

El programa ens permet carregar diferents arxius de clima on situarem la nostra simulació de cultiu: 
a) Clima fred i humit (coolwet).

b) Clima sec i calorós (hotdry).

c) Clima temperat i sec (moddry).

d) Clima temperat i amb humitat moderada (modmod).

e) Clima temperat i humit (modwet).

A més, ens permet fixar paràmetres culturals, com ara el nivell de resistència del cultivar triat, la data de sembra o el rendiment esperat; paràmetres de control (ús del programa, tipus de control) i econòmics (costos i preus de venda) (taula 1).

\begin{tabular}{|c|c|c|c|c|c|}
\hline \multirow{7}{*}{ Potato } & \multirow{3}{*}{ Resistance level } & \multicolumn{3}{|l|}{ Low } & (x) \\
\hline & & \multicolumn{3}{|c|}{ Moderate } & \\
\hline & & \multicolumn{3}{|l|}{ High } & \\
\hline & \multirow{3}{*}{ Harvest season } & \multicolumn{3}{|l|}{ Early } & \\
\hline & & \multicolumn{3}{|l|}{ Mid } & (x) \\
\hline & & \multicolumn{3}{|l|}{ Late } & \\
\hline & \multicolumn{4}{|l|}{ Yield (kg/ha) } & $(50000)$ \\
\hline \multirow{2}{*}{ Environment } & \multicolumn{4}{|c|}{ Length of season (d) } & (120) \\
\hline & \multicolumn{4}{|l|}{ Emergence date } & (25/ABR) \\
\hline \multirow{9}{*}{ Inoculum } & \multirow{6}{*}{ Sporangia } & \multirow{2}{*}{ Number } & \multicolumn{2}{|c|}{ As initial inoculum (nr/ha) } & 250000 \\
\hline & & & \multicolumn{2}{|c|}{ Each day (nr/ha/day) } & $(25000)$ \\
\hline & & \multirow{4}{*}{ Source } & \multirow{2}{*}{ Cull pile } & max. sporang./day & 100 \\
\hline & & & & Distance (m) & 10 \\
\hline & & & \multirow{2}{*}{$\begin{array}{l}\text { Unsprayed } \\
\text { field }\end{array}$} & max. sporang./ha & $(5000000)$ \\
\hline & & & & Distance (m) & $(10)$ \\
\hline & \multirow{3}{*}{ Infections } & Number & \multicolumn{2}{|c|}{ Initial infections (nr/ha) } & $(10000)$ \\
\hline & & \multirow{2}{*}{ Source } & \multicolumn{2}{|c|}{ Infected seed (infections/ha) } & $(10000)$ \\
\hline & & & \multicolumn{2}{|c|}{ Volunteers (infections/ha) } & $(10000)$ \\
\hline Management & \multicolumn{4}{|l|}{ Use blitecast } & (No) \\
\hline \multirow{5}{*}{ Economics } & \multirow{5}{*}{ Costs } & \multicolumn{3}{|c|}{ Fixed costs } & $(1000)$ \\
\hline & & \multicolumn{3}{|c|}{ Spray application } & (100) \\
\hline & & \multicolumn{3}{|c|}{ Protectant cost } & (50) \\
\hline & & \multicolumn{3}{|c|}{ Systemic cost } & (150) \\
\hline & & Blitecast & & & (150) \\
\hline Price & Market price (pe & $\mathrm{kg})$ & & & $(0,35)$ \\
\hline File & & & & & \\
\hline
\end{tabular}

Taula 1. Paràmetres que ens permet regular el programa. En negreta es reflecteixen els valors amb els quals treballarem inicialment (taula 2). Entre parèntesis es presenta un exemple dels valors que podríem donar 


\section{Objectius de la pràctica}

Els objectius d'aquesta pràctica es concreten en:

1. Conèixer el patogen responsable del míldiu de la creïlla i la seua virulència.

2. Aprendre a utilitzar un model en protecció vegetal: simulació d'un atac de míldiu.

3. Presa de decisions.

\section{Desenvolupament de la pràctica}

\subsection{Material}

El material necessari per dur a terme aquesta pràctica consta de:

- Ordinador

- Programa de simulació: Lateblight

\subsection{Metodologia}

Una vegada descarregat el programa, fixats tots els paràmetres que ens dóna la taula 1 i seleccionat el tipus de clima (file, run), podem començar la simulació i decidir pel nostre compte -o segons el que aconselle el model (si hem optat per activar-lo (blitecast use)) - quants tractaments cal fer i amb quin tipus de producte (preventiu o curatiu). Al final, veurem com queda el nostre cultiu, quin és el nivell de danys que ha patit i quins són els rendiment brut i net.

Començarem la pràctica amb l'exemple donat en la taula 1 , on veurem la influència del clima i del tipus d'estratègia de control en els resultats del cultiu (taula 2).

A continuació, cada estudiant farà una simulació on, variant no més d'un o dos paràmetres, estudie la influència d'algun paràmetre en la magnitud de l'extensió de la malaltia i els resultats econòmics del cultiu. Basat en aquest estudi, haurà de presentar un informe on s'expliquen i es discutisquen els resultats obtinguts. 


\begin{tabular}{|c|c|c|c|c|}
\hline & $\begin{array}{l}\text { Inicial; coolwet } \\
\text { sense interven- } \\
\text { ció (1) }\end{array}$ & $\begin{array}{l}\text { Idem anterior } \\
\text { cull pile a } 1 \mathbf{~ m ~} \\
\text { (2) }\end{array}$ & $\begin{array}{l}\text { (2) amb tracta- } \\
\text { ments preventius } \\
\text { segons Blitecast }\end{array}$ & $\begin{array}{l}\text { (2) amb tracta- } \\
\text { ments curatius } \\
\text { segons infeccions }\end{array}$ \\
\hline \multirow{3}{*}{$\begin{array}{l}\text { \% BLIGHTED FOLIAGE } \\
\text { \% BLIGHTED TUBERS } \\
\text { YIELD REPORT }\end{array}$} & 91.75 & 95.60 & 0.05 & 45.71 \\
\hline & 19.40 & 24.0 & 0.00 & 0.35 \\
\hline & & & & \\
\hline Total potential yield & 17498.75 & 17498.75 & 17498.75 & 17498.75 \\
\hline Yield losses due to plant blight & 2062.77 & 2365.23 & 1.55 & 936.37 \\
\hline Yield losses due to tuber blight & 2988.74 & 3634.02 & 0.00 & 0.00 \\
\hline Total losses due to all blight & 5051.51 & 5999.25 & 1.55 & 936.37 \\
\hline Net yield & 12447.24 & 11499.50 & 17497.20 & 16562.30 \\
\hline \multicolumn{5}{|l|}{ SPRAY REPORT } \\
\hline Protectant (nr sprays; cost) & - & - & $17 ; 1063.74$ & \\
\hline Systemic (nr sprays; cost) & - & - & - & $\begin{array}{r}3 ; \\
99.12\end{array}$ \\
\hline \multicolumn{5}{|l|}{ COST REPORT } \\
\hline Fixed costs & 1000.00 & 1000.00 & 1000.00 & 1000.00 \\
\hline Spray costs & - & - & 1063.74 & 99.12 \\
\hline Application costs & - & - & 1700.00 & 300.00 \\
\hline Blitecast costs & - & - & 150.00 & \\
\hline Net profit & 11447.24 & 10499.50 & 13583.29 & 15163.11 \\
\hline
\end{tabular}

Taula 2. Exemple de resultats (net profit: 'beneficis') fixant els paràmetres de la taula 1, amb un clima fred i humit; amb les mateixes condicions anteriors però amb una pila de creilles de rebuig a 1 metre de distància; fent els tractaments preventius aconsellats pel model; i, per últim, fent els tractaments curatius segons les infeccions observades

\subsection{Vocabulari}

Per facilitar la utilització del programa a continuació s'indiquen els vocables anglesos que hi apareixen i la seua traducció:

Adjacent unsprayed potato fields: camps veïns no tractats químicament Blitecast cost: preu del programa Blitecast

Blighted foliage: planta amb símptomes de míldiu

Blighted tubers: creilles amb símptomes de míldiu

Certified seed potatoes: creilles de sembra certificades

Cull piles: piles de rebuig

Cultivar: cultivar

Distance: distància

Early: primerenca

Economics: dades econòmiques

Emergence date: data d'emergència

Environment: ambient 
Field: camp

File: fitxer

Fixed costs: costos fixes

Harvest season: estació de collita

High: alta

Initial: inicial

Infected seed: 1lavor infectada

Infection: infecció

Inoculum: inòcul

Kill vines: matar la planta

Late: tardana

Leaf, leaves: fulla, fulles

Length of season: durada de l'estació

Low: baixa

Management: gestió

Market cost: preus de venda

Mid o Middle: mitjana

Moderate: moderada

Moisture: humitat

Net profit: benefici net

Net yield: rendiment final

Number: nombre

Protectant: tractament preventiu

Protectant cost: cost del tractament preventiu

Protectant fungicide: fungicida preventiu

Rainfall: pluja

Residues: residus

Resistence levels: nivells de resistència

Source: font, origen

Sporangia: esporangis

Spray application: polvorització

Spray report: informe dels tractaments

Systemic: tractament sistèmic

Systemic cost: cost del tractament sistèmic

Systemic fungicide: fungicida sistèmic

Temperature: temperatura

Total losses due to all blight: pèrdues totals de collita degudes al míldiu

Total potential yield: rendiment potencial

Uncertified seed potatoes: creïlles de sembra no certificada

Unsprayed field: camp no tractat

Use (to): utilitzar

Volunteers: plantes de la collita anterior

Weather forecast: previsions meteorològiques

Yield: rendiment

Yield report: informe de rendiment

Yield losses due to plant blight: pèrdues de collita degudes al míldiu en la planta

Yield losses due to tuber blight: pèrdues de collita degudes al míldiu en la creïlla 


\section{EIXIDA 1}

\section{Lluita autocida com a estratègia de control. Biofäbrica de mascles estèrils de Caudete de las Fuentes}

\section{Antecedents}

\subsection{La mosca mediterrània de la fruita, Ceratitis capitata}

La mosca mediterrània de la fruita Ceratitis capitata (Wiedemann) (Diptera: Tephritidae) (figura 1) és una plaga endèmica de les àrees citrícoles mediterrànies. La seua elevada adaptabilitat a quasi tot tipus de climes, el seu alt potencial reproductor i la seua extrema polifàgia (més de 260 tipus diferents de fruita (Thomas et al., 2007)) en fan una de les plagues que més danys ocasionen en l'agricultura mundial i espanyola. A la Comunitat Valenciana els problemes que ocasiona són d'una importància particular donada l'expansió creixent de varietats extraprimerenques de cítrics, les quals són molt sensibles al seu atac.

Els danys que provoca en la fruita són múltiples. Per una banda, la femella realitza la posta en el fruit, i l'orifici que provoca amb l'oviscapte permet l'entrada d'altres insectes i microorganismes que afavoreixen la putrefacció del fruit, si bé l'única presència de la picada ja és suficient per devaluar la fruita. D'altra banda, el desenvolupament de la larva provoca infeccions secundàries que afavoreixen la caiguda prematura del fruit a més de disminuir-ne la qualitat organolèptica i la quantitat de polpa. Tant la presència de picades com d'altres símptomes causen un rebuig de la fruita que en dificulta la comercialització i exportació a d'altres mercats, on en molts casos s'imposen mesures quarantenàries.

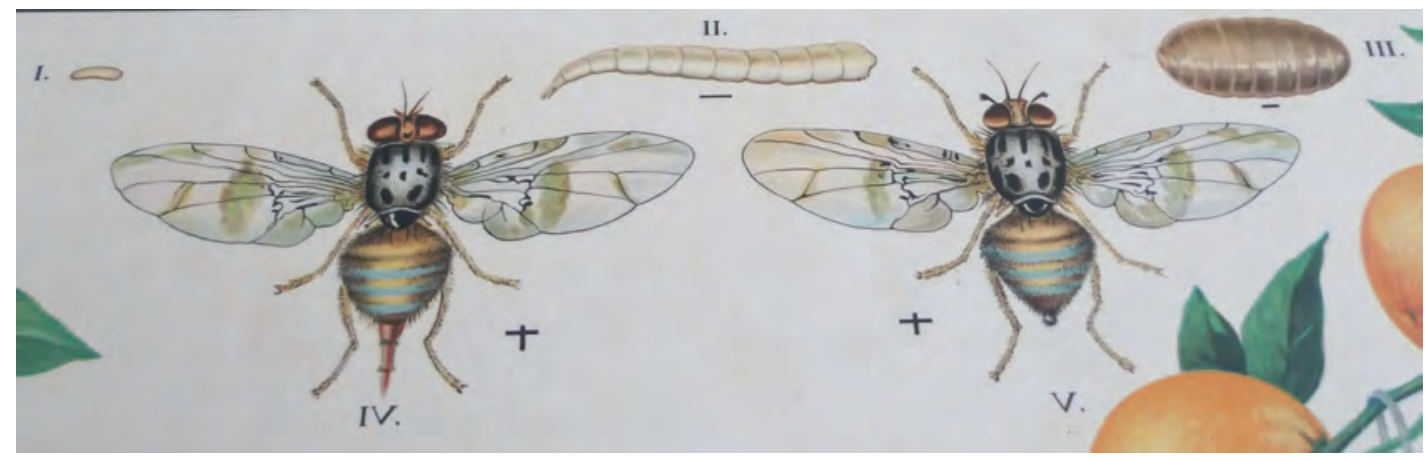

Figura 1. Estats de la mosca mediterrània de la fruita Ceratitis capitata. D'esquerra a dreta i de dalt a baix: ou, larva, pupari, adult femella i mascle 


\subsection{Control de la mosca mediterrània de la fruita}

El control de la mosca actualment se centra en el seguiment de les poblacions al llarg de l'any mitjançant l'ús de mosquers per aconseguir la detecció precoç de les primeres femelles adultes. Quan les captures arriben al llindar de tractament es poden aplicar tractaments terrestres mitjançant insecticides sols o barrejats amb proteïnes hidrolitzades que actuen com a esquer.

Tanmateix, el descobriment de poblacions resistents a plaguicides com el malation (Magaña et al., 2007; Ortego et al., 2005), els efectes negatius que ocasionen els plaguicides sobre la fauna auxiliar (Cohen et al., 1987, 1988; Daane et al., 1990; Ehler i Endicott, 1984; Troetschler, 1983; Urbaneja et al., 2004) i la salut humana (Barr i Angerer, 2006; Edwards et al., 2007; Marty et al., 1994), i la creixent necessitat de fruita fresca lliure d'insecticides, han propiciat la recerca d'altres sistemes de lluita que siguen més respectuosos com és, en el cas que ens pertoca, el control autocida o Tècnica de l'Insecte Estèril (TIE o sIT, de l'anglès, Sterile Insect Technique).

\subsection{Lluita autocida o Tècnica de l'Insecte Estèril (TIE)}

La lluita autocida consisteix en l'esterilització per irradiació d'un gran nombre de mascles que, en ser alliberats a gran escala, competiran amb els mascles salvatges per fecundar les femelles, i donaran lloc a una descendència no viable.

Per aconseguir aquesta esterilitat dels mascles cal irradiar els insectes en l'estadi de pupa. Les dosis d'irradiació varien en funció de l'espècie d'insecte en qüestió i dels llocs on s'aplique (Bakri, 2005); i d'aquesta irradiació depèn gran quantitat de paràmetres biològics i fisiològics, que condicionaran l'èxit del mascle estèril en la lluita per fecundar les femelles salvatges (San Andrés et al., 2007a).

Aquesta tècnica, com que és específica a nivell d'espècie -s'empra com a agent biològic de control de la mateixa espècie, i d'ací el nom de lluita autocida-, (no hi ha transferència d'agents tòxics, ni d'introducció de cap material genètic nou en les poblacions ja existents (els organismes alliberats no es poden autoreplicar)...), es considera que és un dels mètodes de control de plagues menys perjudicials tant per a la fauna auxiliar com per al medi ambient i la salut humana (Hendrich et al., 2002). L'únic inconvenient que presenta la TIE és la gran inversió de mitjans i persones que cal per a tot el procés.

La TIE s'ha utilitzat amb èxit contra espècies plaga com el cuc barrinador del bestiar, Cochliomyia hominivorax (Coquerel), la carpocapsa Cydia pomonella (L.), la mosca tse-tse (Glossinia spp.), diverses espècies de mosquits (Culex spp., Anopheles spp.) i diverses espècies de tefrítids entre els quals es troba C. capitata (Dyck et al., 2005). 
El programa de la TIE com a mètode de prevenció, supressió o eradicació de C. capitata s'està realitzant en diferents països, i no va ser fins a l'any 2002 que es va començar a la Comunitat Valenciana (Primo-Millo, 2003), si bé anteriorment ja s'havien fet temptatives a menor escala a Tenerife, Múrcia i Granada (Mellado, 1971; Mellado et al., 1970, 1974). L'any 2002, les pupes ja esterilitzades s'importaven des de la bioplanta KM8 de Mendoza (Argentina) i es feien evolucionar a l'evolucionari de mascles estèrils de l'Institut Valencià d'Investigacions Agràries (IVIA) (Montcada). Comprovat el seu èxit a reduïda i mitjana escala es va plantejar la construcció d'una biofàbrica en terreny nacional on produir i esterilitzar els mascles de la mosca, i d'aquesta manera evitar-ne les despeses generades per la importació (Argilés i Tejedo, 2007).

\subsection{Biofàbrica de mascles estèrils a Caudete de las Fuentes}

L'any 2007 la Conselleria d'Agricultura, Pesca i Alimentació va inaugurar, a Caudete de las Fuentes (València), la biofäbrica de producció de mascles estèrils de $C$. capitata (figura 2). Aquesta biofàbrica té una capacitat de producció màxima de 540 milions de pupes de mascles estèrils a la setmana, quantitat estimada per cobrir la superfície citrícola de la Comunitat Valenciana sota el programa de la TIE.

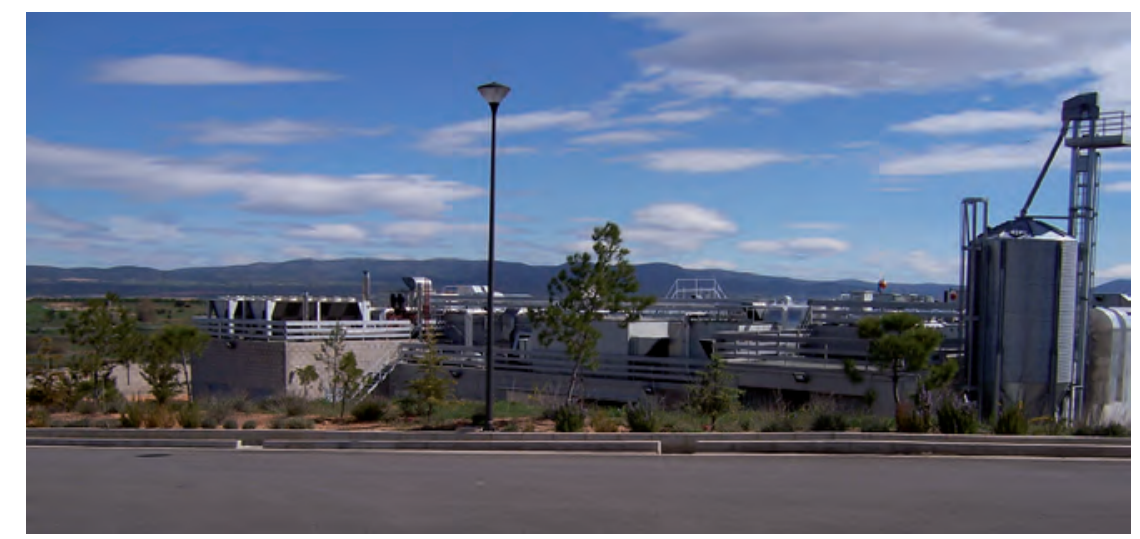

Figura 2. Biofàbrica de producció de pupes de mascles estèrils de Ceratitis capitata a Caudete de las Fuentes

Segons Argilés i Tejedo (2007) perquè un programa de lluita autocida tinga efecte cal que totes les activitats que s'hi integren tinguen èxit. Aquestes són:

- cria massiva d'insectes i esterilització de les pupes,

- desenvolupament de les pupes,

- alliberació en camp,

- seguiment de les poblacions. 


\section{Cria massiva d'insectes}

L'objectiu principal de la cria massiva és reconduir la producció de la mosca a l'obtenció d'un gran nombre de mascles, que són els que interessen per a la TIE. Aquest fet s'aconsegueix gràcies a la utilització de la soca de $C$. capitata anomenada «Vienna 8», la qual presenta, com a característiques fonamentals: una coloració de pupari diferent segons el sexe (mutació natural: les femelles són blanques i els mascles marrons) $\mathrm{i}$ una sensibilitat letal diferent segons sexes a temperatures elevades, de manera que una exposició continuada a $32^{\circ} \mathrm{C}$ provoca la mort només de les femelles (mutació induïda) (figura 3).

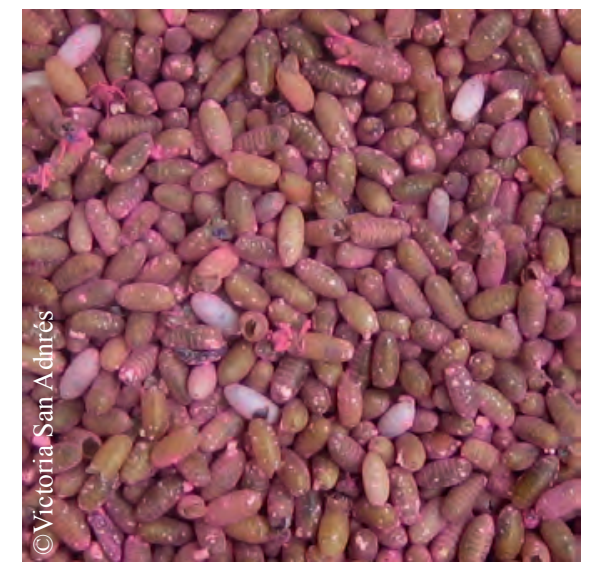

Figura 3. Pupes que mostren la diferent pigmentació natural en funció del sexe, amb restes del pigment fluoresceïna que s'usa per tenyir-les i diferenciar-les en camp de les salvatges

Per aconseguir que aquests dos caràcters es mantinguen de manera constant en la cria i no desapareguen per mutacions, es manté un sistema de cria que es denomina amplificació de colònies. Es parteix d'una colònia «filtre», on es comprova individualment que estan presents tots dos caràcters, i a partir d'aquesta s'amplifica la població mitjançant 4 generacions. Els ous de la cinquena generació seran els que rebran el tractament tèrmic durant la incubació per tal de seleccionar només els ous mascle.

Les femelles obtingudes de les diferents colònies, després d'un període de preposta de 6 dies, comencen a pondre durant 10 dies a l'interior de gàbies recobertes de tela muselina. Durant aquest temps, les femelles travessen amb l'oviscapte aquesta tela $\mathrm{i}$ en realitzen la posta sobre la superfície. Els ous que ponen cauen a un safata amb aigua col-locada a la part més baixa, on s'arrepleguen per sedimentació (figura 4). Aquests ous a continuació passen a la sala d'incubació i es torna a iniciar el cicle. 

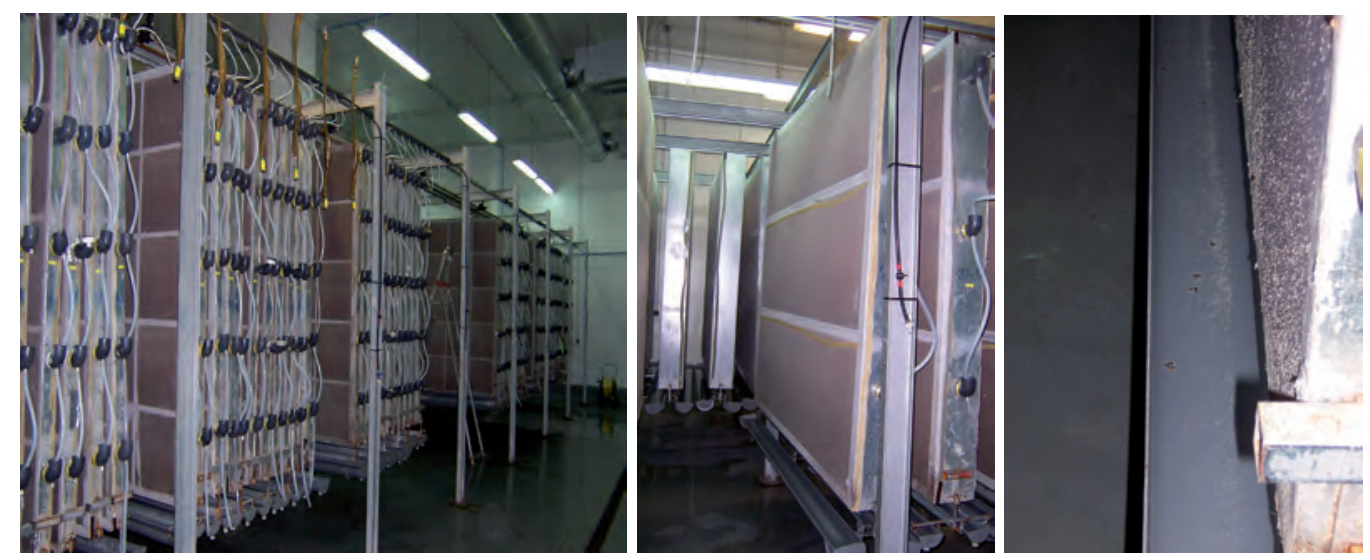

Figura 4. Gàbies emprades per arreplegar els ous de Ceratitis capitata.

A la foto de la dreta es pot apreciar com cauen a la safata on, per sedimentació, s'arrepleguen i es tanca el cicle

Perquè els ous eclosen, aquests s'incuben al bany maria durant 48 hores a $24^{\circ} \mathrm{C}$; si bé la colònia destinada a produir només mascles se sotmet a $32^{\circ} \mathrm{C}$ les últimes 24 hores d'incubació per matar les femelles (figura 5).
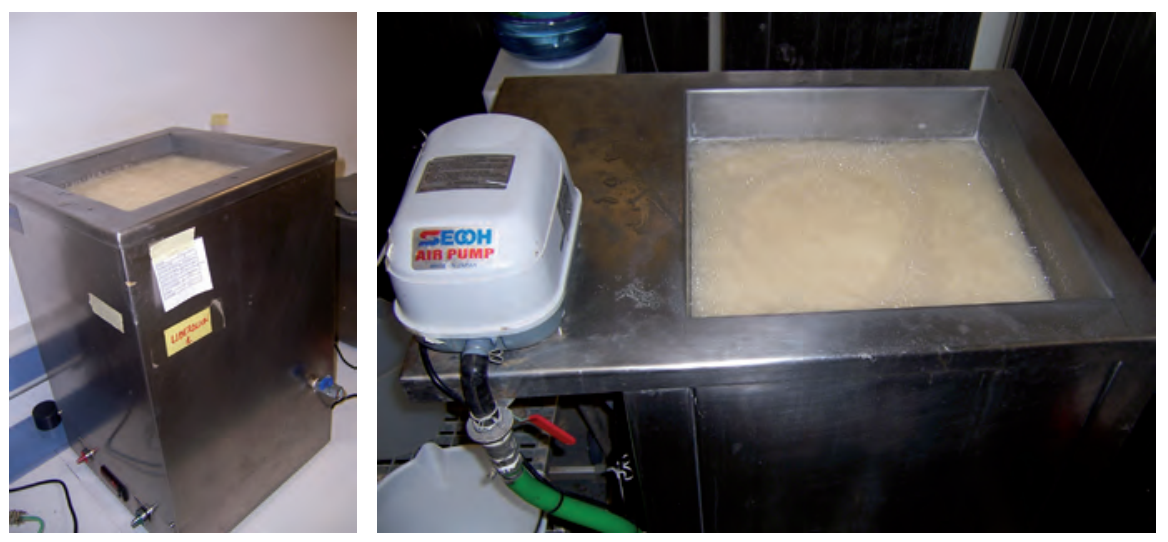

Figura 5. Incubadora amb els ous de Ceratitis capitata en aigua al bany maria

Els ous se sembren en safates amb una dieta formada per aigua, polpa de remolatxa deshidratada, sucre i llevat de cervesa, a més de conservants com benzoat de sodi i àcid clorhídric per tal d'evitar el desenvolupament de microorganismes (figura 6). Els ingredients es barregen en una mescladora de 2 tones de capacitat. La densitat d'ous és de 125.000-150.000 ous per safata amb $5 \mathrm{~kg}$ de dieta. 

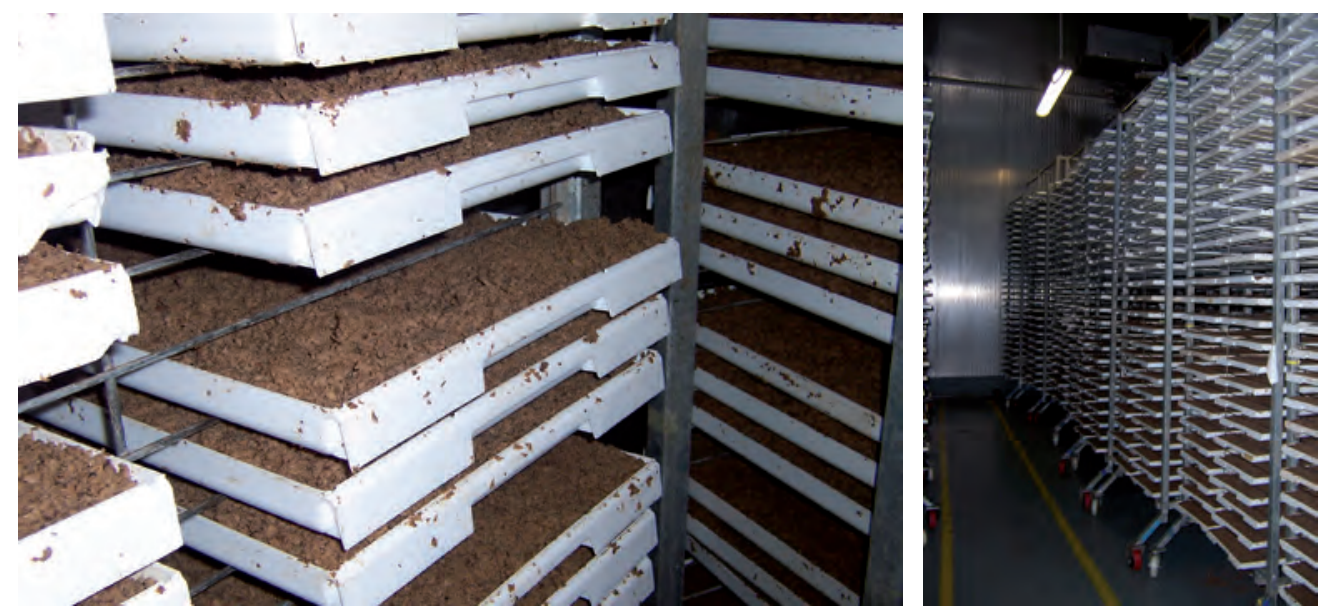

Figura 6. Safates amb la dieta i els ous acabats de sembrar

Les larves passen els tres estadis larvaris alimentant-se d'aquesta dieta, si bé les condicions ambientals de temperatura i humitat varien i passen de $28^{\circ} \mathrm{C}$ i $100 \%$ d'humitat a $24^{\circ} \mathrm{C}$ i $70 \%$ d'humitat. Al voltant del setè dia, quan la pupació és pròxima, les larves fugen de la dieta i busquen un lloc fose i sec on pupar. Normalment s'empra el segó de blat com a substrat per a la pupació, el qual es disposa a l'interior d'una safata a la part més baixa de la pila (figura 7). El romanent de dieta s'empra per a l'alimentació del bestiar després d'eliminar-ne mitjançant un tractament tèrmic totes les possibles larves que no hagen abandonat el substrat per pupar.

Les safates amb les pupes es mantenen durant 12 o 13 dies en càmeres sense illuminar, amb temperatures al voltant dels $19^{\circ} \mathrm{C}$ i humitats inferiors.
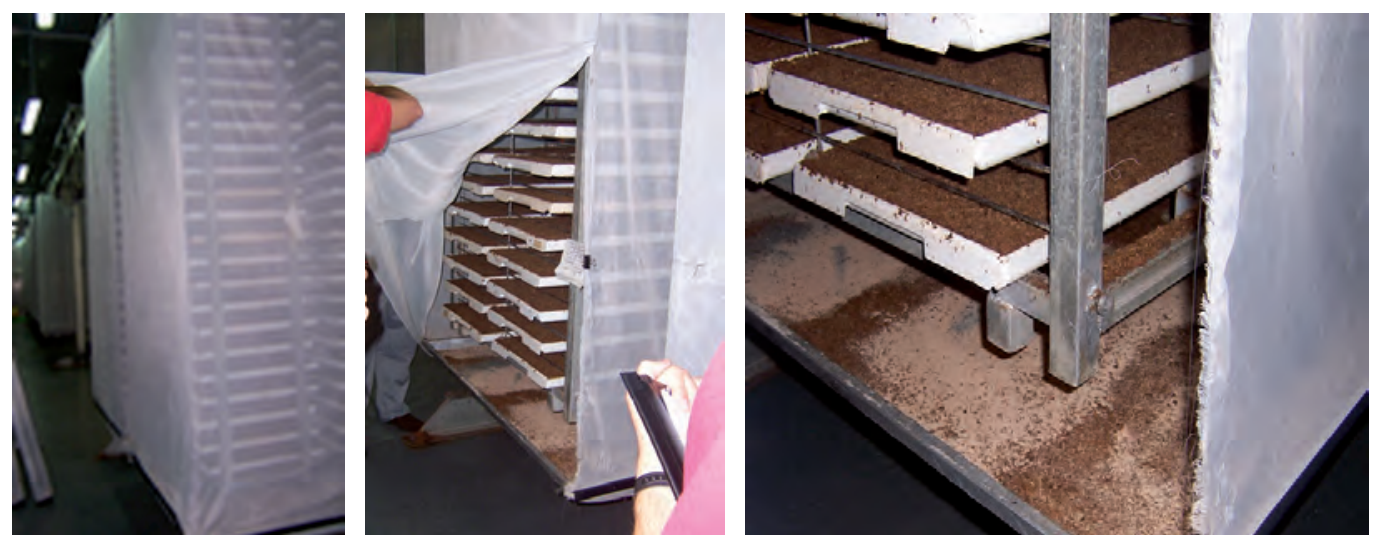

Figura 7. Safates amb larves en el tercer estadi botant per buscar un refugi i pupar. A la part inferior s'observa el segó de blat emprat com a substrat de pupació

Quan està pròxima l'emergència dels adults, les pupes destinades al manteniment de la cria o a les successives amplificacions van a les sales d'adults, mentre que les destinades als programes TIE es recobreixen amb el pigment fluoresceïna, que permetrà reconèixer-les després en les captures de camp sota llum epifluorescent (figures 3 i 8). 

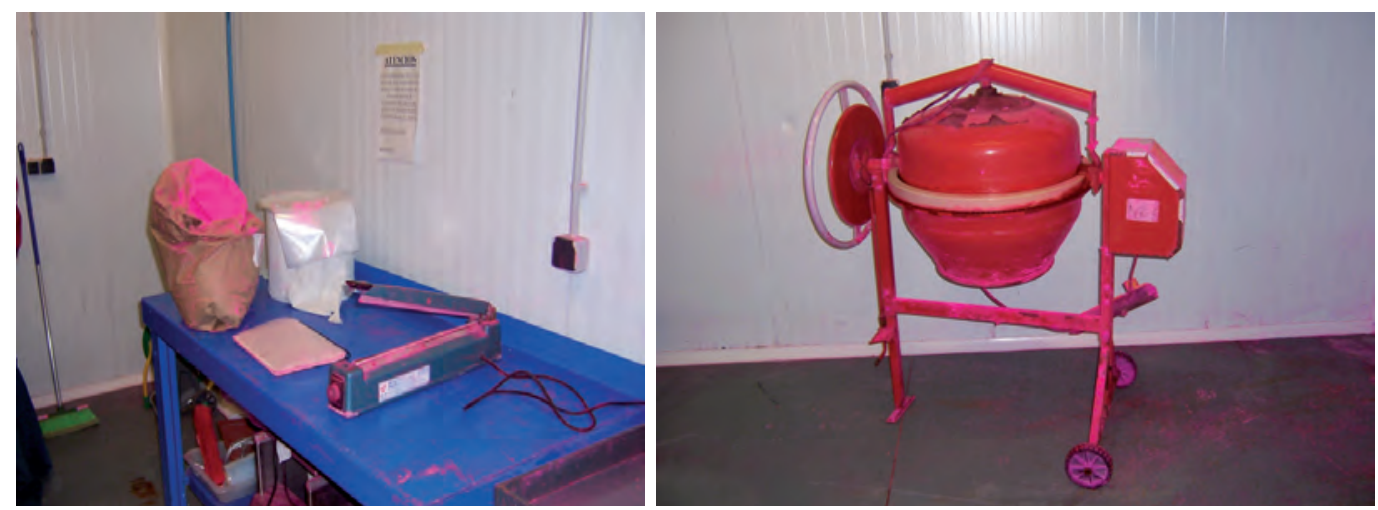

Figura 8. Bossa amb el pigment fluoresceïna i barrejadora on s'introdueixen les pupes per recobrir-les homogèniament amb el pigment

Amb aquest pigment, les pupes s'introduiran en bosses tancades i, en absència d'oxigen per reduir els possibles danys, s'esterilitzen amb radiació $\beta$ de 85 Gy en una empresa especialitzada ubicada a Tarancón (Conca), que utilitza electrons accelerats per aconseguir-ho.

\section{Evolució de les pupes}

L'evolució de les pupes estèrils té lloc a l'evolucionari de mascles estèrils ubicat a l'IVIA (figura 9). Les pupes s'introdueixen en gàbies on emergeixen els adults. Aquests adults s'alimenten amb sucre i proteïnes durant 4-5 dies fins que arriben a la maduresa sexual, moment en què s'alliberaran una volta comprovat que estan en les condicions òptimes. Un dia abans d'alliberar-los, se sotmetran a un tractament d'aromateràpia amb oli de gingebre per incrementar-los la competitivitat sexual.

Previ a l'alliberament es faran diversos controls de qualitat com són l'anàlisi de pes de la pupa, percentatge d'emergència dels adults i capacitat de vol, longevitat sota estrès, competència per les femelles, duració de la còpula, etc. (FAO/IAEA/USDA, 2003). Aquests controls de qualitat estan fixats per assegurar que la qualitat dels mascles estèrils és l'adequada per competir amb els salvatges i que l'acoblament es produïsca amb els mascles estèrils alliberats, factor clau en l'èxit dels programes TIE.
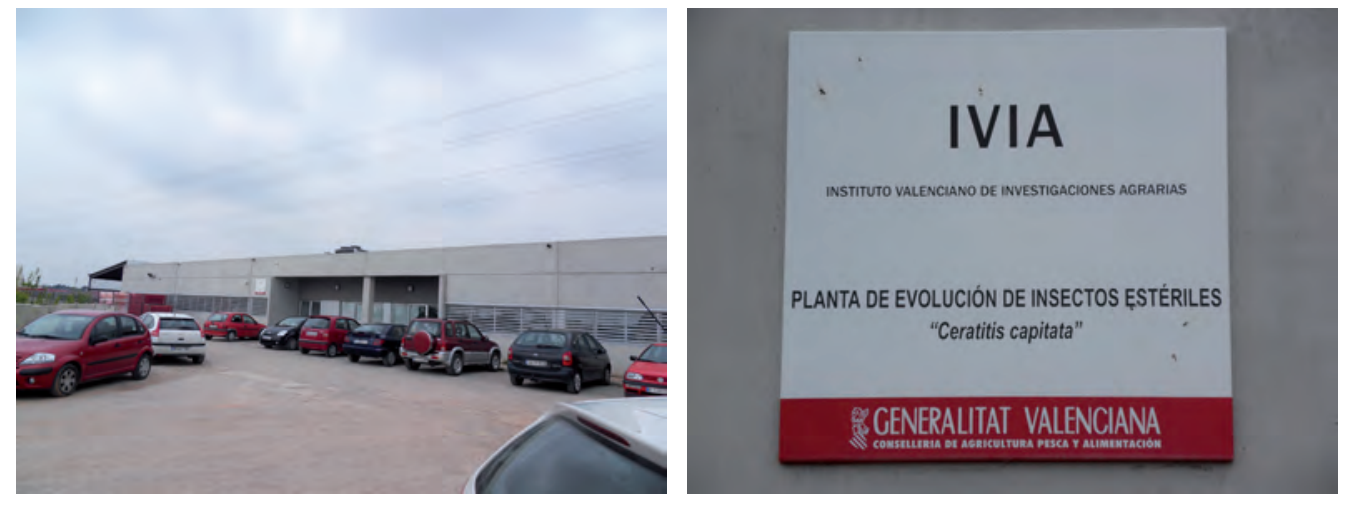

Figura 9. Evolucionari de mascles estèrils ubicat a l'IVIA 
Les gàbies amb els adults s'introdueixen en càmeres refrigerades a una temperatura al voltant dels $4^{\circ} \mathrm{C}$ per inactivar els mascles. Aquests es carregaran en uns contenidors també refrigerats i es transportaran a la pista d'aterratge, on es carregaran en aeroplans modificats per permetre'n l'alliberació.

\section{Alliberament dels adults}

Per realitzar l'alliberament dels adults, el departament d'Agroenginyeria de l'IVIA ha dissenyat una màquina dosificadora que permet la conservació de les mosques a baixa temperatura per inactivar-les, al mateix temps que permet l'alliberament dels adults d'una manera precisa en funció del nivell d'atac de l'àrea sobrevolada. Normalment la solta es fa a una altura de 150 a $300 \mathrm{~m}$.

\section{Seguiment de les poblacions i verificació de l'èxit del programa}

El seguiment de les poblacions tant de salvatges com d'estèrils permet confirmar que tot el procés iniciat en la biofäbrica ha arribat a bon port. Per tal d'aconseguir un control adequat, la proporció de mascles estèrils respecte de mascles fèrtils ha de ser com a mínim de 10:1.

Aquest èxit s'avalua amb la proporció de mascles estèrils i salvatges capturats en trampes amb feromones (adults amb i sense restes de fluoresceïna) (figura 10), determinant el nombre d'ous fèrtils en la fruita, visualitzant l'esperma en l'espermateca de la femella per analitzar si estan fecundades i, més recentment, amb tècniques moleculars que permeten detectar si la femella capturada ha copulat o no i l'origen (estèril o salvatge) de l'esperma en les espermateques (Sabater et al., 2007; San Andrés et al., 2007b).
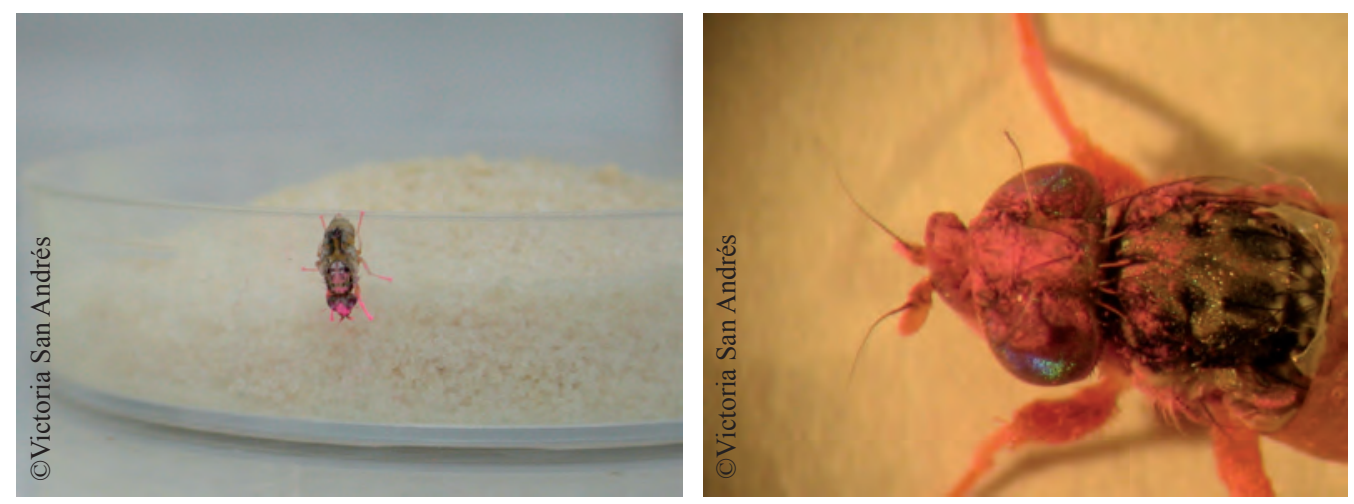

Figura 10. Adults amb restes de pigment fluoresceïna en el cos

Però el factor més important perquè les soltes siguen efectives és que l'alliberament dels mascles es faça quan les poblacions de mosques salvatges encara no estiguen molt altes, i per tant cal recórrer a la integració de diferents estratègies de control per assegurar l'èxit de la TIE. 


\section{Objectius de la pràctica}

El objectius d'aquesta pràctica es concreten en:

1. Conèixer en què consisteix la lluita autocida com a estratègia de control.

2. Saber com funciona la cria en massa d'insectes i, en concret, de la mosca mediterrània de la fruita.

\section{Desenvolupament de la pràctica}

\subsection{Material}

El material necessari per dur a terme aquesta pràctica és:

- Bloc de notes

- Bolígraf

- Càmera fotogràfica (opcional)

\subsection{Metodologia}

Una vegada arribats a la planta de mascles estèrils, la persona responsable ens explicarà tot el procés de producció dels mascles estèrils, des de la sembra dels ous i amplificació de les colònies fins a l'esterilització de les pupes per irradiació, pas previ abans de ser enviats a l'evolucionari de l'IVIA. Com a treball, caldrà fer un breu resum de tot el procés donant importància a l'ús d'aquesta tècnica com a estratègia de control. 


\section{EIXIDA 2}

\section{Control biològic augmentatiu. Insectari d'Almassora de la Conselleria d'Agricultura, Pesca i Alimentació}

\section{Antecedents}

\subsection{Conceptes}

Fisher i Finney (1964) van definir el terme insectari com un lloc on es conserven o es propaguen insectes, de manera que tècnicament el concepte d'insectari aniria des de branques o arbres emmallats des dels quals es propaguen els insectes -tal com es va fer a Califòrnia amb el coccinèl-lid Rodolia cardinalis (Mulsant)- fins a instal-lacions climàtiques controlades com les que es poden trobar en diferents llocs i països. En el context del present manual, un insectari és un lloc destinat a la producció en massa d'enemics naturals per utilitzar-los posteriorment en la lluita biològica contra les plagues. Encara que la paraula insectari fa al-lusió a «insecte», als insectaris també es poden produir altres artròpodes no insectes com els àcars fitoseids o els àcars laelàpids, emprats en la lluita biològica contra nombroses plagues.

Abans d'avançar en el concepte d'insectari i les seues funcions, cal recordar què és una espècie plaga, un enemic natural, i què es considera control biològic. En el sentit ampli del terme, una espècie plaga és qualsevol agent perjudicial per a les plantes o per als productes vegetals (FAO, 1990; revisat FAO, 1995; CIPF, 1997). Un organisme es considerarà plaga quan la seua presència supose una pèrdua econòmica per a la producció del cultiu, resultat d'una reducció del valor de la collita o d'un increment dels costos de producció. Es tracta, per tant, d'un concepte essencialment econòmic on existeix un nivell o llindar econòmic per damunt del qual una població és perjudicial. En definitiva, «Plaga és tot allò que l'home considera que és plaga» (Rey, 1976). Un enemic natural, auxiliar o útil és un artròpode (insecte o àcar), però també nematode o un altre animal, fong, bacteri, que viu i s'alimenta d'altres artròpodes, nematodes o animals plaga, però també de fongs o males brosses. Amb un significat similar existeix l'entomòfag que, d'acord amb el sentit etimològic del terme, es tractaria d'aquell ser viu que s'alimenta d'insectes (o d'artròpodes, si admetem que el terme entomon es refereix als animals articulats $\mathrm{o}$ artròpodes, i no únicament als insectes) (Avilla, 2005). Per acabar, el control biològic ( $\mathrm{CB})$, lluita biològica o biocontrol consisteix en l'ús d'organismes vius (enemics naturals) per disminuir la densitat de població o l'impacte d'un organisme plaga i fer-lo menys abundant o menys perjudicial del que és. Aquesta lluita es pot aplicar per al control d'artròpodes plaga, fongs i males brosses (Bellows i Fisher, 1999; Eilenberg et al., 2001; Viñuela, 2005; Jacas i Urbaneja, 2010). Normalment es parla de lluita microbiològica quan s'empren microorganismes entomopatògens 
(virus, bactèries, fongs i nematodes) i lluita macrobiològica, o senzillament lluita biològica, quan s'empren organismes naturals artròpodes (insectes, àcars $\mathrm{i}$ aranyes) (Viñuela, 2005). El control biològic cada vegada té més defensors gràcies als seus avantatges en front del control químic (taula 1).

\begin{tabular}{|l|l|l|}
\cline { 2 - 3 } \multicolumn{1}{c|}{} & Control biològic & Control químic \\
\hline Nombre de productes assajats & 2.000 & $>1$ milió \\
\hline Relació d'èxit & $1: 10$ & $1: 200.000$ \\
\hline Cost del desenvolupament & 2 milions $\$$ & 400 milions $\$$ \\
\hline Temps de desenvolupament & 10 anys & 10 anys \\
\hline Relació Benefici/Inversió & $20: 1$ & $2: 1$ \\
\hline Risc de resistència & Cap o baixa & Gran \\
\hline Especificitat & Gran & Menuda \\
\hline Efectes secundaris & Cap o baixos & Molts \\
\hline
\end{tabular}

Taula 1. Comparativa entre el control biològic i el control químic de plagues (adaptat de Van Lenteren, 2007)

D'altra banda, els beneficis del control biològic de cara al productor i a la comunitat són molts i gens menyspreables. Alguns es reflecteixen en la taula 2.

\begin{tabular}{|c|c|}
\hline \multicolumn{2}{|c|}{ Beneficis } \\
\hline Agricultor & Comunitat \\
\hline $\begin{array}{l}\text { Els treballadors no es veuen exposats a pro- } \\
\text { ductes químics. }\end{array}$ & $\begin{array}{l}\text { El control biològic és apreciat pel públic } \\
\text { general. }\end{array}$ \\
\hline $\begin{array}{l}\text { Absència de residus en el producte que es } \\
\text { comercialitza. }\end{array}$ & $\begin{array}{l}\text { Els cultius biològics aconsegueixen un mi- } \\
\text { llor preu de venda. }\end{array}$ \\
\hline $\begin{array}{l}\text { Absència d'efectes fitotòxics i d'avortament } \\
\text { prematur de flors i fruits. }\end{array}$ & $\begin{array}{l}\text { Baix nivell de contaminació d'aliments, } \\
\text { aigua, terra i aire. }\end{array}$ \\
\hline Augment del rendiment. & $\begin{array}{l}\text { Contribució a una producció sostenible } \\
\text { dels aliments. }\end{array}$ \\
\hline $\begin{array}{l}\text { L'alliberació dels enemics naturals és més } \\
\text { ràpida i agradable que la polvorització. }\end{array}$ & $\begin{array}{l}\text { Contribució a la protecció i millora } \\
\text { de la biodiversitat. }\end{array}$ \\
\hline $\begin{array}{l}\text { L'alliberació dels enemics naturals es fa quan } \\
\text { l'agricultor té temps, i és d'efecte permanent. }\end{array}$ & \\
\hline $\begin{array}{l}\text { Tan sols suposa una comprovació ocasional, } \\
\text { a diferència del control químic, que necessita } \\
\text { una atenció contínua. }\end{array}$ & \\
\hline $\begin{array}{l}\text { Algunes plagues només poden ser controlades } \\
\text { amb enemics naturals. }\end{array}$ & \\
\hline $\begin{array}{l}\text { Desapareix el període de seguretat; la collita } \\
\text { sempre és possible. }\end{array}$ & \\
\hline $\begin{array}{l}\text { El control biològic és permanent: l'enemic } \\
\text { natural que és bon enemic natural, sempre } \\
\text { serà bo. }\end{array}$ & \\
\hline
\end{tabular}

Taula 2. Beneficis que obté el productor i la comunitat en emprar el control biològic en lloc del control químic (adaptat de Van Lenteren, 2003a; 2007) 


\subsection{Tipus de control biològic}

Les plagues es poden combatre dins del marc de la lluita biològica mitjançant el descobriment i la introducció d'enemics naturals d'espècies exòtiques (CB clàssic o per inoculació, segons autors), mantenint les poblacions dels ja existents en les parcel·les (СВ de conservació) o fent soltes augmentatives d'enemics criats artificialment (СB per inoculació estacional i св per inundació) (Eilenberg et al., 2001; Albajes, 2005; Viñuela, 2005).

Les soltes augmentatives en les quals s'allibera un gran nombre d'enemics naturals de manera periòdica s'estan aplicant comercialment en grans àrees de cultius de tot el món i han arribat a substituir en alguns casos els plaguicides amb eficàcies i costos comparables amb aquests, a més de generar nombrosos beneficis (Van Lenteren, 2003b) (taula 1 i 2). Dins de les soltes augmentatives cal destacar els dos tipus de control biològic esmentats prèviament, ja que és en aquests on apareix la figura de l'insectari, que facilita els enemics naturals per a la seua solta.

En el cB per inundació els organismes es crien en massa i s'alliberen periòdicament en gran nombre per aconseguir un control immediat de la plaga. En aquest cas el control de la plaga l'efectua l'enemic natural alliberat, que actua com un insecticida biològic. Exemples d'aquest tipus de control els trobem en les soltes de Psyttalia concolor Szépligetti contra la mosca de l'olivera Bactrocera oleae (Gmelin), o de Trichogramma evanescens (Westwood) contra la barrinadora del panís Ostrinia nubilalis Hübner (Urbaneja i Jacas, 2009). En el cB per inoculació estacional, els enemics naturals es crien en massa, i periòdicament s'alliberen però mai en grans quantitats, i s'espera que es reproduïsquen en el cultiu per controlar la plaga. En aquest cas no s'allibera un nombre tan gran d'individus per aconseguir un control immediat de la plaga, sinó que el que es busca és un establiment de l'enemic natural, que continuarà el seu cicle, i tindran lloc diverses generacions de l'entomòfag en la mateixa estació del cultiu, arribant en alguns casos a controlar totalment la plaga si el cultiu es manté durant llarg termini (Van Lenteren et al., 2003a). Alguns exemples són les soltes de Cryptolaemus montrouzieri Mulsant i de Leptomastix dactylopii Howard en cítrics per al control de Planococcus citri (Risso) o de diverses espècies d'Encarsia i d'Eretmocerus contra mosques blanques en hivernacle (Urbaneja i Jacas, 2009). El св per inoculació estacional és el que més s'ha desenvolupat en aquests últims anys, fonamentalment en cultius d'hivernacle, on ja són molts els èxits aconseguits (Jacas et al., 2005; Jacas i Urbaneja, 2010).

\subsection{Tipus d'insectaris}

L'ús comercial dels enemics naturals no va començar a Europa fins el 1968 amb els àcars fitoseids i a hores d'ara s'ha estès a altres grups d'artròpodes i a un gran nombre de països (Viñuela, 2005). Fins aleshores s'havien introduït els enemics naturals dins dels programes de control biològic clàssic o per inoculació. Al món existeixen al voltant de 85 productors privats d'enemics naturals que gestionen més de 125 espècies d'enemics naturals, a més d'altres institucions organitzades per l'estat o per agrupacions d'agricultors, que també poden vendre enemics naturals (Van Lenteren, 2003c). 
Al nostre país els insectaris poden ser de dos tipus: de gestió privada o pública. Els insectaris de gestió privada es dediquen a la cria massiva d'insectes útils per posteriorment vendre'ls als diferents organismes que els sol-liciten, ja siguen agricultors particulars o grans empreses hortofructícoles. Algunes d'aquestes empreses de més repercussió en el nostre país són Koppert Biological Systems, empresa originària dels Països Baixos; Biobest Biological Systems, empresa belga; Syngenta Agro S.A., amb seu a Madrid, o Bioplanet, empresa italiana situada a Cesena (Itàlia). Aquestes empreses es dediquen a la venda tant d'artròpodes depredadors com de parasitoides, fongs i nematodes entomopatògens, a més de produir agents pol-linitzadors com Bombus terrestris (L.). Un altre exemple, encara que no pròpiament de venda d'insectes és el del Grupo Eibol, S.L., empresa originària de Puçol (València), i amb seu en diversos països, que s'ha especialitzat en la producció de diferents bacteris entomopatògens com Bacillus thuringiensis, però també en suspensions microbials que ajuden a la defensa de la planta davant les agressions climàtiques o de plagues.

Per contra, existeixen els insectaris de gestió publica pertanyents al Servei de Sanitat Vegetal de la Conselleria d'Agricultura, Pesca i Alimentació, ubicats a Almassora (Castelló) i Silla (València) (figura 1), que ofereixen als agricultors aquests enemics naturals prèvia sol-licitud (figura 2) i previ acompliment d'uns requisits mínims de tractaments químics respectuosos. És de la gestió d'un d'aquests insectaris, concretament de l'ubicat a Almassora, del que tracta aquesta pràctica.
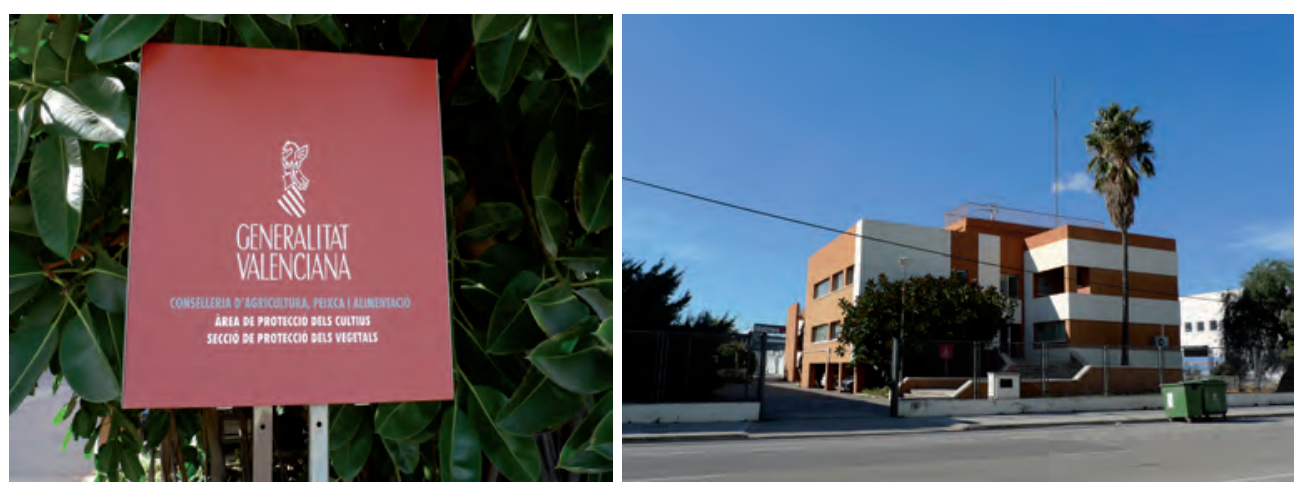

Figura 1. Cartell situat a l'entrada dels insectaris de la Generalitat Valenciana (esquerra) i vista frontal de l'insectari d'Almassora (Castelló) (dreta) 
TIPODEPRODUCCION: $\quad$ Convencional $\square \quad$ P. integrada $\square \quad$ A. ecológica $\square$ CUMPLIMIENTO REQUISITOS (marcar en caso afirmativo y adiuntar documentación comespondiente) Acreditación de Producción Integrade o Biológica Listado de tratamientos en el último año (cuaderno de campo) Previsión de tratamientos hasta final de año (ficha adjunta)

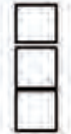

Entidad peticionaria

Dirección:

CP: Doblación Provincia:

Teléfono: Persona de contacto:

Tíno. Contacto:

DATOS PARCELA/S: Pertenencia a: Cooperativa $\square$ ADV $\square$ Nombre:

\begin{tabular}{|l|l|l|l|l|l|l|l|l|}
\hline Témino muniśpal & \multicolumn{2}{|l|}{} & & & & & \\
\hline Poligono & & & & & & & & \\
\hline Parcela & & & & & & & & \\
\hline Variedad & & & & & & & & \\
\hline Superficie & & & & & & & & \\
\hline
\end{tabular}

\section{GRADO DE AFECCION}

Sueltas en años anteriores ( $\mathrm{S} / \mathrm{No}$ ) Años con sueltas

\section{PETICION INSECTOS}

\begin{tabular}{|c|c|c|c|c|}
\hline \multirow[t]{2}{*}{ PLAGA } & \multirow{2}{*}{$\begin{array}{l}\text { DISTRIBUCION (focos o } \\
\text { regular) }\end{array}$} & \multirow{2}{*}{$\begin{array}{c}\text { NIVEL. PLAGA (de } \\
\text { I a 3) }\end{array}$} & \multicolumn{2}{|c|}{ A rellenar por la Administración } \\
\hline & & & ESPECIE & CANTIDAD \\
\hline & & & & \\
\hline & & & & \\
\hline & & & & \\
\hline & & & & \\
\hline
\end{tabular}

Nota: El máximo $n^{\circ}$ de insectos que se puede entregar es de 2.500 Cryptolaemus y 4.000 Leptomastix/Anagyrus para particulares, y 25.000 y 40.000 respectivamente para asodaciones.

UTILIZACION Campo $\square$ Insectorio $\square \quad$ Ensayos $\square$

FICHA DE PREVISION DE TRATAMIENTOS REALIZADOS Y PREVISTOS (HASTA FIN DE AÑO)

\begin{tabular}{|l|l|l|l|l|}
\hline Poligono & Parcela & Fecha & \multicolumn{1}{|c|}{ Formulado } & Observaciones \\
\hline & & & & \\
\hline & & & & \\
\hline & & & & \\
\hline & & & & \\
\hline & & & & \\
\hline
\end{tabular}

N Registro:

Fecha de petición:

Firma
He recibido los insectos amiba detallados Fecha de entrega

Firma:

Figura 2. Exemple d'imprès que s'ha d'omplir per sol-licitar insectes útils als insectaris del Servei de Sanitat Vegetal de la Generalitat Valenciana 
El punt més important és aconseguir que aquests insectaris, privats o públics, siguen capaços de proporcionar als agricultors els enemics naturals en nombre suficient perquè els puguen alliberar periòdicament, en les quantitats necessàries i de la qualitat adequada. I això no sempre passa. És un clam molt freqüent dels interessats la urgència de la creació de més insectaris públics, però fonamentalment privats, que cobrisquen les necessitats del mercat (Jacas et al., 2001).

Aquests insectaris tenen el deure de complir no només amb la cria sinó també amb la investigació per millorar la producció, qualitat i abaratiment de la cria dels enemics naturals.

D'altra banda, l'ús comercial dels enemics naturals a gran escala geogràfica i d'un grup tan divers d'artròpodes requereix una legislació eficaç que vigile l'entrada i l'alliberament d'organismes no presents al nostre país (FAO, 1996; EPPO, 1999, 2000 i 2010; Anònim, 2002), i que controle la qualitat dels organismes alliberats (Viñuela, 2005).

\subsection{Enemics naturals}

Els enemics naturals o fauna auxiliar que poden subministrar aquests insectaris són molt variats i s'agrupen fonamentalment en dos grups: depredadors i parasitoides.

Els parasitoides són aquells organismes que durant la fase larvària viuen i s'alimenten dins (endoparasitoides) o sobre (ectoparasitoides) el cos d'un únic hoste per matar-lo finalment, donant lloc a un adult de vida lliure. Als parasitoides els cal per tant un únic hoste per completar el desenvolupament. Aquests es diferencien dels paràsits sensu stricto principalment en què destrueixen l'hoste abans d'arribar a l'estadi adult, mentre que el paràsit aconsegueix el seu aliment d'un altre organisme causant-li una lesió però sense arribar a matar-lo, almenys de manera directa. D'altra banda, al depredador li cal consumir un nombre elevat de preses de la mateixa o de diverses espècies per arribar a l'estadi adult (Godfray, 1994; Pina, 2009).

El major grup de parasitoides pertany a l'ordre Hymenoptera, com ara Cales noacki Howard, que parasita la mosca blanca cotonosa dels cítrics Aleurothrixus floccosus (Maskell); Aphytis melinus DeBach, que ataca al poll roig de Califòrnia Aonidiella aurantii (Maskell); Diglyphus isaea (Walker), ectoparasitoide molt eficaç de larves del dípter minador Liriomyza trifolii (Burgess), o diverses espècies del gènere Trichogramma que exerceixen un bon control sobre els ous de diversos insectes (figura 3) (Pina, 2009). Però també es poden trobar parasitoides pertanyents a altres ordres, com els dípters, on destaquen els taquínids Leskia aurea (Fallén), que ataca el sèsid de la pomera Synanthedon myopaeformis; Lydella thompsoni Herting, parasitoide més abundant de les erugues barrinadores del panís Ostrinia nubilalis (Hübner) i Sesamia nonagrioides (Lefebvre); o recentment, Trichopoda pennipes (F.), parasitoide de la xinxa verda Nezara viridula (L.) (figura 3) (Pina, 2009). 

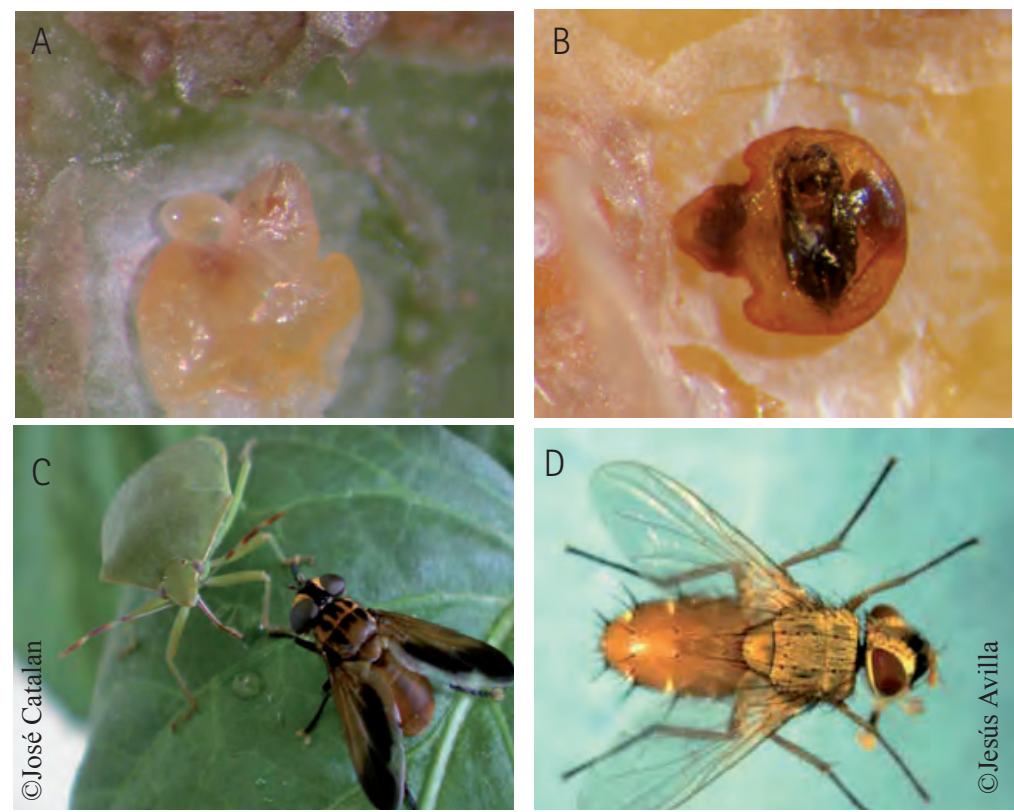

Figura 3. Exemples de parasitoides. A) Larva de l'himenòpter ectoparasitoide Aphytis melinus sobre el cos del poll roig de Califòrnia; B) pupa de l'himenòpter endoparasitoide Encarsia perniciosi (Tower) a l'interior del cos del poll roig de Califòrnia; C) taquínid adult de Trichopoda pennipes intentant realitzar la posta sobre la xinxa verda Nezara viridula; D) taquínid adult de Leskia aurea.

Els ordres on podem trobar espècies depredadores són molt més amples. En trobem des d'hemípters antocòrids com Orius o Anthocoris; mírids com Nesidiocoris tenuis Reuter; coleòpters amb representants en diverses famílies com els caràbids, estafilínids o coccinèl·lids (marietes), però també dípters (sírfids, cecidòmids, múscids), neuròpters (crisoperles, entre d'altres), tisanòpters i dermàpters. Dins dels aràcnids trobem els àcars fitoseids, com els depredadors clàssics d'àcars fitòfags, però també de mosques blanques, de nimfes d'hemípters, de trips... i els aràcnids licòsids i clubiònids (figura 4) (Urbaneja et al., 2005).

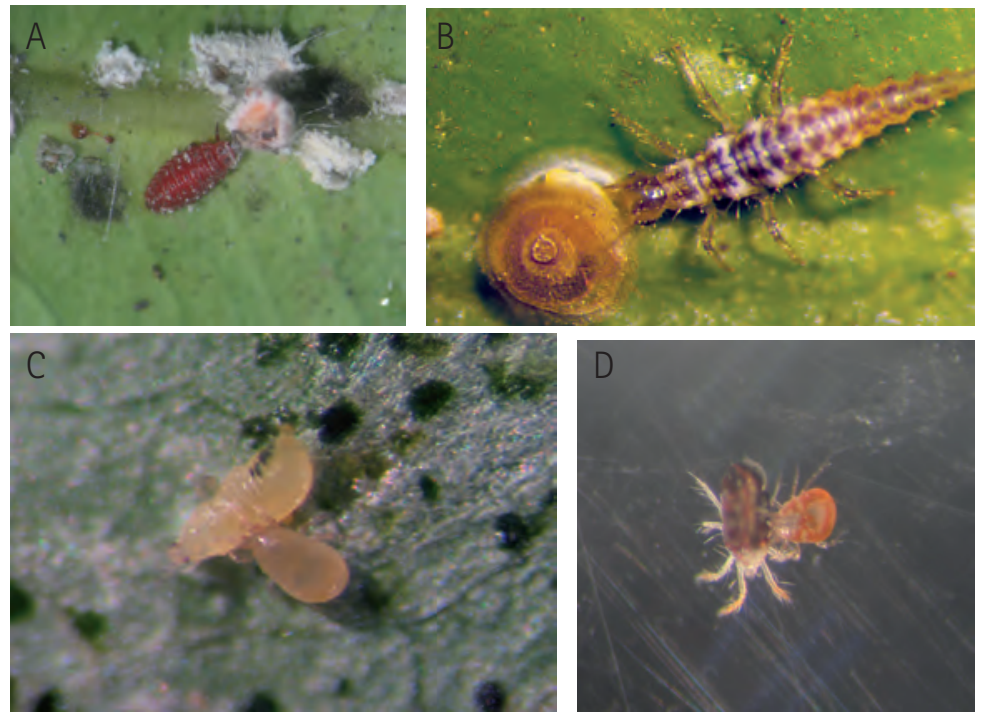

Figura 4. Exemples de depredadors. A) Larva del coccinèl-lid depredador Rodolia cardinalis atacant la cotxinilla acanalada Icerya purchasi Maskell; B) larva del neuròpter Chrysoperla sp. depredant el poll roig de Califòrnia; C) adult del fitoseid depredador Neoseiulus californicus (McGregor) alimentant-se d'una nimfa de trip; D) adult de $N$. californicus depredant l'aranya roja Tetranychus urticae Koch 


\subsection{Cria en massa}

L'objectiu d'un programa de cria en massa és produir amb un mínim d'hores de treball i d'espai el màxim nombre de femelles fèrtils d'un organisme útil en el mínim temps possible i de la manera més econòmica (Finney i Fisher, 1964).

La cria en massa dels enemics naturals té tres passos crítics:

- cria de l'enemic natural sobre el seu hoste o un de substitució que reduïsca el cost del procés,

- conservació de l'hoste i de l'enemic natural en condicions adequades durant el màxim període de temps; han de superar tots els controls de qualitat,

- enviament del material a la seua destinació en les condicions apropiades per a la seua solta immediata.

El primer pas d'un programa de cria en massa o massiva és intentar criar l'enemic natural en el seu hoste natural (organisme plaga), de manera que siga econòmicament rendible. Encara que molts enemics naturals es poden reproduir d'aquesta manera, molts altres necessiten hostes alternatius que, de vegades, porten implícites plantes hostes diferents. Un exemple de planta hoste de substitució el trobem en la cria de l'hemípter Planococcus citri, que malgrat que el seu hoste natural són els cítrics, es cria sobre creïlles grillades.

El segon punt perquè siga econòmicament profitosa la cria és intentar canviar l'hoste natural (planta hoste) per un medi de cria artificial. En aquest sentit aparegueren a principis del segle $\mathrm{xx}$ les dietes artificials, que han anat millorant-se progressivament, buscant sempre el mínim preu i el menor espai ocupat. No obstant, aquesta substitució de l'hoste original per una dieta artificial de vegades porta implícits alguns problemes posteriors. Un exemple de dieta artificial el trobem en la cria de la mosca mediterrània de la fruita, Ceratitis capitata (Wiedemann). En aquest cas, les larves, en lloc de desenvolupar-se en l'interior del fruit, procés que seria altament costós i depenent de l'estació, es crien en una dieta a base de segó, sucre i llevat de cervesa, i els adults s'alimenten tan sols d'una barreja de sucres i proteïnes hidrolitzades.

L'últim punt quan s'intenta minimitzar els costos de la cria de l'hoste és buscar la manera de criar l'enemic natural directament en aquesta dieta artificial, si bé aquest punt s'ha aconseguit només en alguns organismes del gènere Trichogramma (parasitoide d'ous) i Chrysoperla (depredador generalista).

Una vegada s'ha aconseguit reproduir l'enemic natural, el segon pas crític és la conservació o manteniment de l'organisme durant un període llarg de temps. La capacitat de poder conservar-los i emmagatzemar-los permet fer una producció continuada en lloc d'una producció estacional, augmentar la reserva d'entomòfags per compensar els períodes de baixa producció o pics de demanda, i fins i tot permet reproduir-los en el moment millor de l'any, com per exemple en l'òptim vegetatiu de la planta (Van Lenteren i Tommasini, 2003). Bons exemples de conservació els trobem en els ous de Sitotroga cerealella (Olivier), que poden ser 
preservats en nitrogen líquid per a la producció de Trichogramma, o els d'Ephestia kuehniella Zeller, que poden ser esterilitzats amb llum ultraviolada i després congelats durant diversos mesos sense perdre el seu valor nutritiu per a la cria en massa de diverses espècies dels gèneres Chrysoperla o Orius. L'himenòpter parasitoide Diglyphus isaea es pot emmagatzemar durant almenys dos mesos a baixes temperatures sense que se n'altere greument la longevitat o la fecunditat.

Finalment, una vegada produïts i envasats, els enemics naturals han d'arribar a la seua destinació el més prompte possible. Si el destinatari es troba dins d'una distància en temps inferior a les 48 hores des del seu emmagatzemament, no cal prendre cap mesura extraordinària a part d'evitar una exposició prolongada a elevades o baixes temperatures i una manipulació brusca. Però si se supera aquest límit cal que viatgen en contenidors climatitzats de plàstic o de paper, amb menjar (mel, pol·len o preses) i llocs de refugi (paper, vermiculita, segó de blat...) per minimitzar el canibalisme (figura 5) (Van Lenteren i Tommasini, 2003).
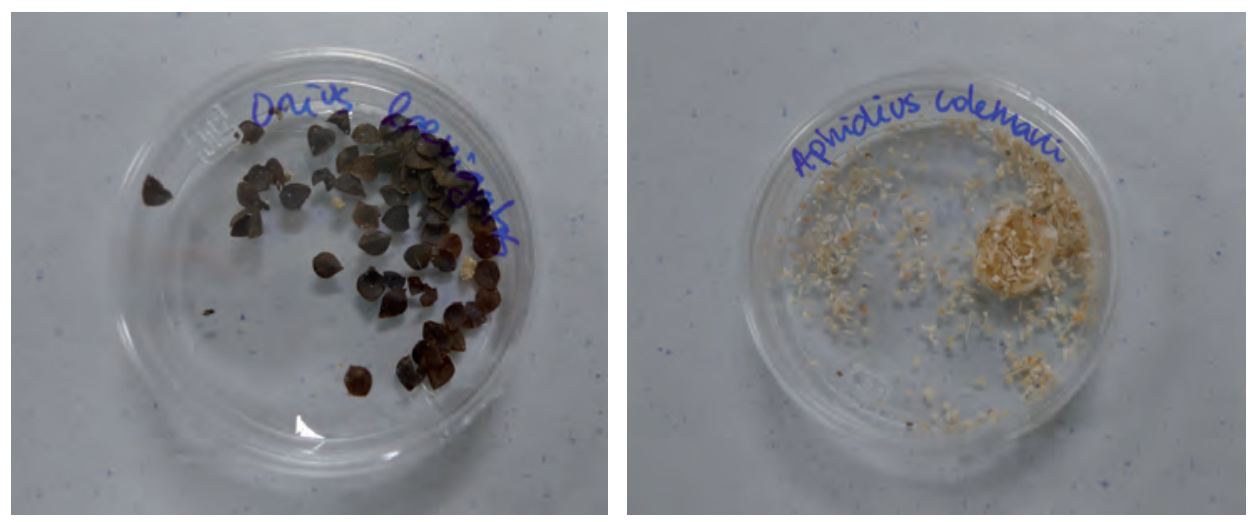

Figura 5. Exemples de substrats emprats en l'enviament de l'hemípter depredador Orius laevigatus (esquerra) i de l'himenòpter parasitoide Aphidius colemani Viereck (dreta)

La solta dels enemics naturals es pot fer quan es veu la plaga, quan es preveu que pot ser-hi encara que no es veja, o quan les poblacions de les plagues tenen un ràpid desenvolupament $i$ cal actuar ràpidament. La dosi de solta, la distribució $i$ la freqüència de solta variarà en funció de si la solta és per inundació o per inoculació. En una solta per inundació la dosi no serà crítica, però sí l'aspecte econòmic. Per contra, en l'alliberament per inoculació la relació plaga-enemic natural serà el factor crític, i el nombre exacte d'individus que cal alliberar es converteix, de vegades, en un assaig de prova i error (Van Lenteren i Tommasini, 2003).

En funció del tipus de cultiu que predomine en una zona, els insectaris reproduiran una espècie o una altra d'enemic natural. Per exemple, els insectaris de gestió privada ubicats al sud d'Espanya s'han especialitzat en enemics naturals que combaten plagues de cultius hortícoles, donada la gran extensió d'aquests cultius en hivernacle al SE de la península Ibèrica. Per contra, als insectaris públics de la Comunitat Valenciana, els enemics naturals que es produeixen estan enfocats principalment a la protecció dels cítrics, i en concret contra còccids plaga. 


\subsection{Organismes que es crien a l'insectari d'Almassora}

A l'insectari d'Almassora, en l'actualitat, es cria un total de 8 enemics naturals per combatre tres còccids plaga: Planococcus citri, Icerya purchasi i Aonidiella aurantii (taula 3 ).

\begin{tabular}{|l|l|l|}
\hline \multicolumn{1}{|c|}{ Espècie plaga } & \multicolumn{1}{|c|}{ Parasitoide } & \multicolumn{1}{c|}{ Depredador } \\
\hline Planococcus citri (Risso) & Leptomastix dactylopii Howard & Cryptolaemus montrouzieri Mulsant \\
\hline Icerya purchasi Maskell & & Rodolia cardinalis (Mulsant) \\
\hline \multirow{4}{*}{ Aonidiella aurantii (Maskell) } & Aphytis melinus DeBach & Rhyzobius lophantae Blaisdell \\
\cline { 2 - 3 } & Aphytis lingnanensis Compere & \\
\cline { 2 - 3 } & Encarsia perniciosi Tower & \\
\cline { 2 - 3 } & Comperiella bifasciata Howard & \\
\hline
\end{tabular}

Taula 3. Enemics naturals produïts a l'insectari d'Almassora

La cria es realitza de manera diferent en funció de l'enemic natural, de manera que varia en alguns casos l'hoste artròpode i vegetal, i sempre en sales climàticament condicionades (figura 6).
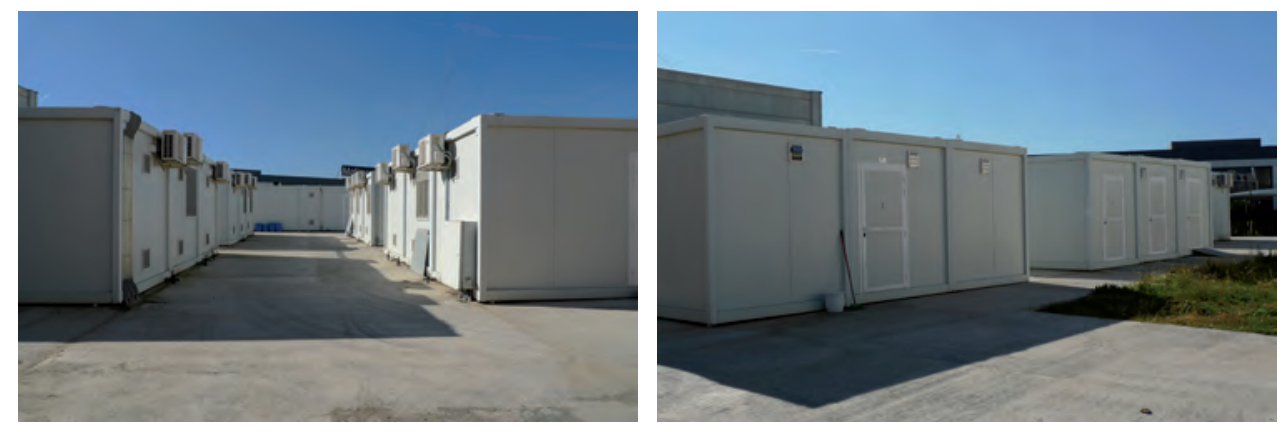

Figura 6. Sales climàticament condicionades on es realitza la cria de la planta hoste, artròpode hoste i enemic natural

A continuació exposarem breument la cria d'aquests en funció de l'organisme plaga que n'és objecte. 


\subsubsection{Cotonet, Planococcus citri}

Per al control d'aquesta plaga l'insectari d'Almassora ha posat a punt les cries d'un himenòpter endoparasitoide i d'un depredador coccinèl-lid. A la taula 4 s'exposen les característiques d'aquests referint la planta hoste i l'artròpode sobre el qual es reprodueixen.

\begin{tabular}{|l|l|l|l|l|l|}
\hline \multicolumn{1}{|c|}{ Enemic natural } & \multicolumn{1}{c|}{ Ordre } & Família & $\begin{array}{c}\text { Comportament } \\
\text { biològic }\end{array}$ & $\begin{array}{c}\text { Planta } \\
\text { hoste }\end{array}$ & Artròpode hoste \\
\hline Leptomastix dactylopii & Hymenoptera & Encyrtidae & Endoparasitoide & Creïlla & Planococcus citri \\
\hline $\begin{array}{l}\text { Cryptolaemus } \\
\text { montrouzieri }\end{array}$ & Coleoptera & $\begin{array}{l}\text { Coccinelli- } \\
\text { dae }\end{array}$ & Depredador & Creïlla & Planococcus citri \\
\hline
\end{tabular}

Taula 4. Característiques principals dels enemics naturals de Planococcus citri

La cria de $C$. montrouzieri es va iniciar amb individus procedents de França, a principis del segle xx, quan va aparèixer el cotonet als cítrics espanyols. Des d'aleshores s'ha mantingut la cria d'aquest coccinèl-lid en diverses instal·lacions, des de l'Escola Agrària de Burjassot fins al Servei de Defensa Contra les Plagues i Inspecció Fitopatològica de Silla i, posteriorment, a Almassora, on encara es cria. Leptomastix dactylopii es va introduir l'any 1977 per complementar l'acció del depredador, donat que cadascun ocupa un nínxol ecològic diferent: L. dactylopii és un endoparasitoide de nimfes del tercer estadi i femelles joves, mentre que C. montrouzieri menja ous i nimfes joves de cotonet.

\section{Cria del cotonet, Planococcus citri}

Com a planta hoste per a la cria de $P$. citri s'empren creïlles, preferentment de la varietat Desirée, per la seua bona germinació i brotació al llarg de tot l'any. Aquestes creïlles se sembren en cubetes de plàstic amb terra arenosa i es traslladen a sales a les fosques fins la seua brotació. Aquest pas és crucial ja que perquè els nous brots no siguen tòxics, cal que aquests estiguen totalment blancs i no desenvolupen fulles ja que d'altra manera no s'aconseguiria la fixació del cotonet. Quan els brots tenen al voltant de 30 o $40 \mathrm{~cm}$ s'inicia la infestació amb el cotonet (figura 7).

Per a la seua infestació, es tallen fulles de pebrer bord (Schinus molle L.) i es deixen caure damunt d'algunes cubetes que ja tinguen producció de nimfes o a terra, en aquells llocs on s'acumulen les nimfes quan troben una escletxa de llum. A les 24 hores es retiren aquestes fulles, que estaran totalment colonitzades per nimfes, $\mathrm{i}$ es dipositen sobre els brots nous que cal infestar. Tan prompte com aquestes fulles s'assequen, les nimfes passaran als brots de creïlla, on es desenvoluparan fins a arribar a l'estadi adequat per ser emprades en la cria del parasitoide o del depredador. Tot el procés es realitza en la foscor. 

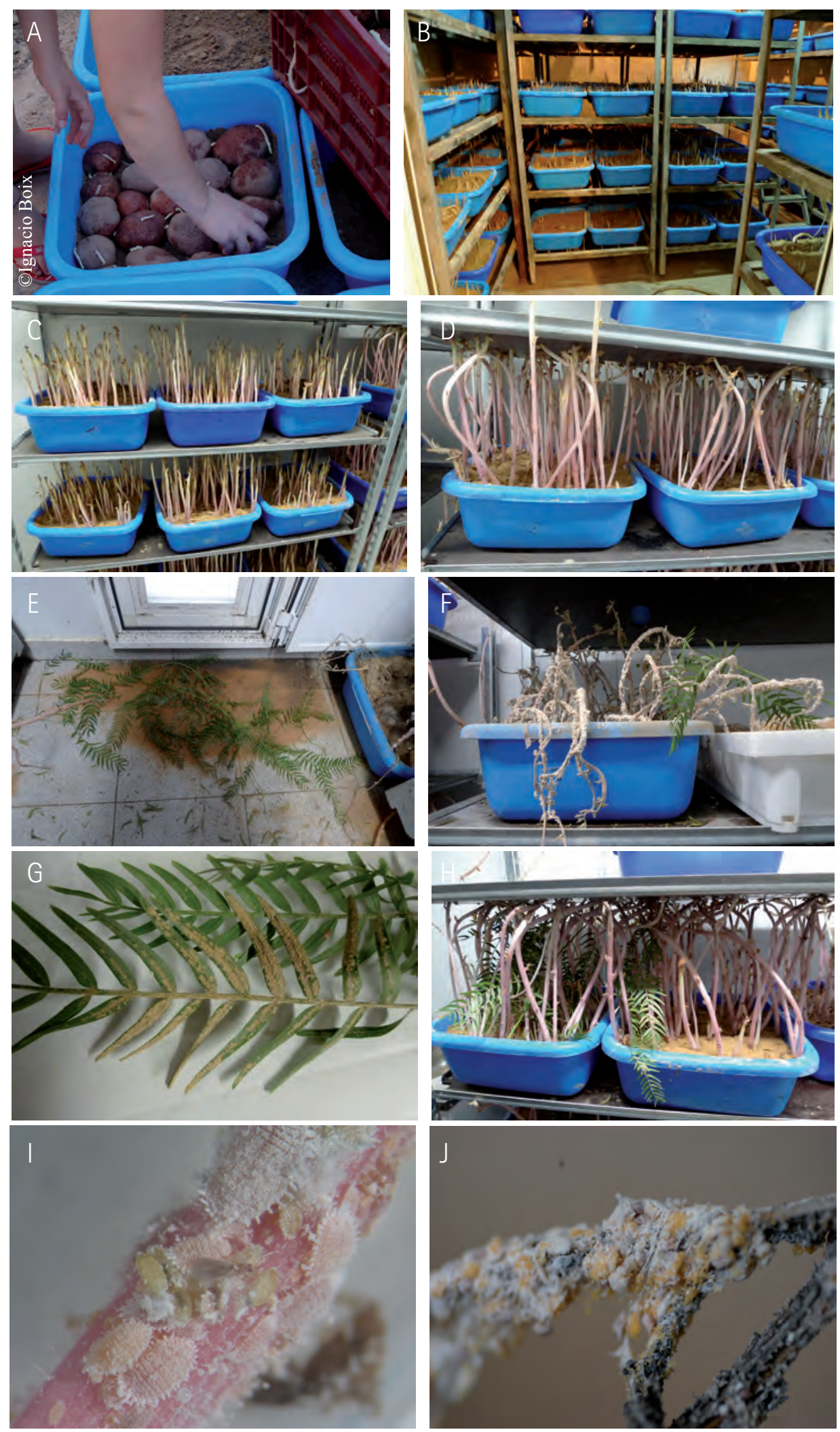

Figura 7. Cria de Planococcus citri. A) Sembra de la creïlla; B) sala de germinació; C) i D) brots en procés de creixement; E) infestació de fulles de pebrer bord amb nimfes de terra; F) infestació de les fulles de pebrer bord directament de cotxinilles en l'estat de nimfa adulta; G) aspecte de la fulla de pebrer bord amb nimfes del cotonet; H) fulla de pebrer bord infestat contaminant els nous brots de creilla; I) diferents estadis del cotonet; J) femelles gràvides amb els sacs ovígers plens d'ous (de color groc) 


\section{Cria del parasitoide Leptomastix dactylopii}

Quan les cotxinilles tenen 21 dies des que es fixen en la creïlla, les cubetes s'introdueixen en gàbies on s'alliberarà un gran nombre de $L$. dactylopii en estat adult. Una vegada han parasitat les cotxinilles, es capturen mitjançant un aspirador entomològic i s'introdueixen en petits flascons de plàstic amb paper parafinat amb mel. Aquest adults i els resultants del parasitisme s'empren per alliberar-los en el camp o per parasitar noves cotxinilles de la cria. Quan s'aspiren els parasitoides és recomanable tenir el llum apagat i la contrafinestra oberta perquè els adults que s'escapen es dirigisquen atrets per la llum a la finestra i puguen ser aspirats sobre la superfície del vidre (figura 8).
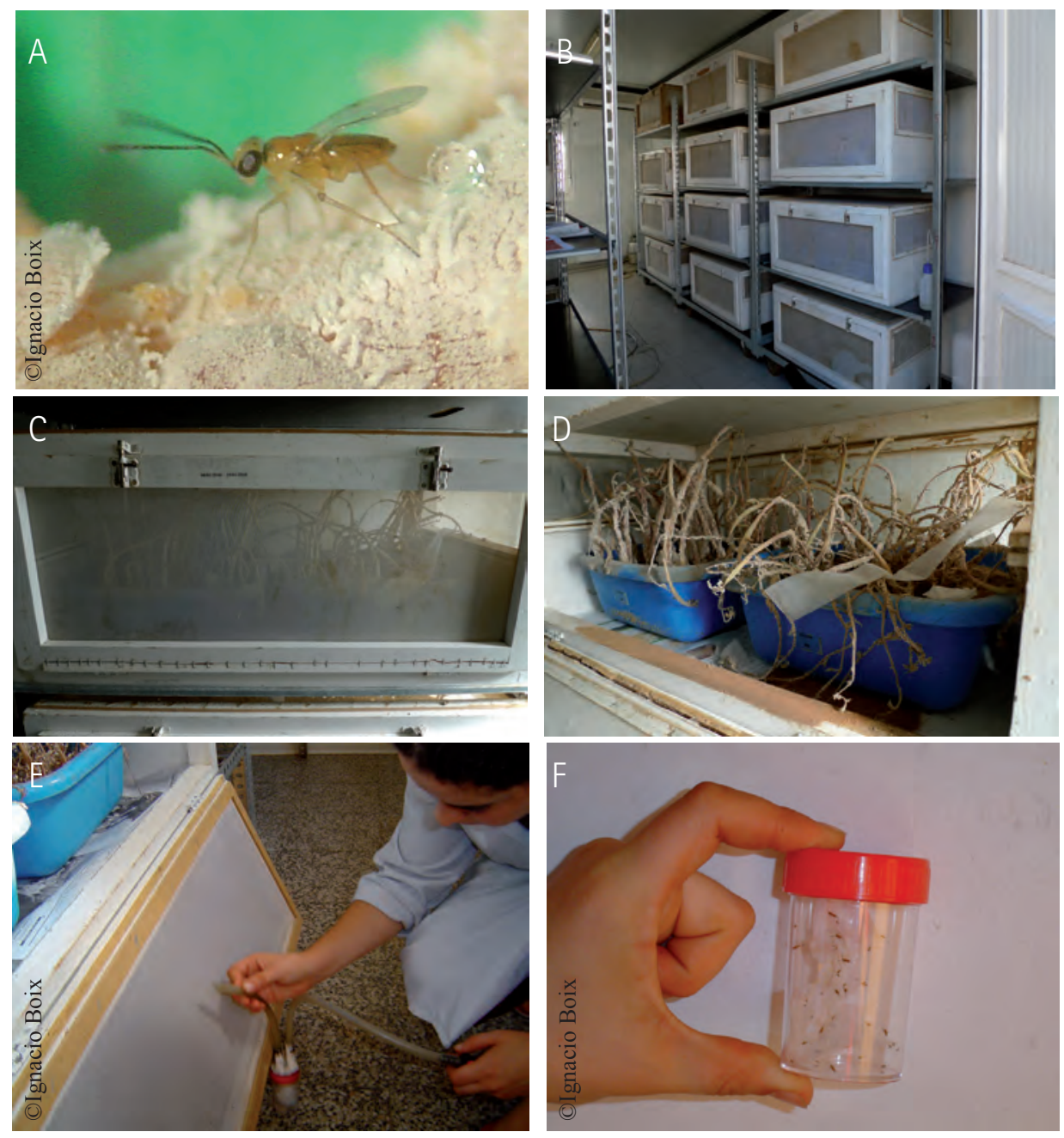

Figura 8. Cria de Leptomastix dactylopii. A) Adult de L. dactylopii buscant l'hoste; B) i C) gàbies emprades en la cria del parasitoide; D) detall del paper parafinat amb mel per alimentar als parasitoides; E) aspiració dels adults; F) recipient amb adults preparat per a la seua alliberació 


\section{Cria del depredador Cryptolaemus montrouzieri}

Quan les cotxinilles tenen al voltant de 30 dies s'introdueix aproximadament un adult de $C$. montrouzieri per quilo de creilla. Aquests adults aprofiten el sac ovíger de la femella per realitzar la posta. Al cap de 35 dies des de la introducció dels adults s'observen els primers adults de la nova generació volant. Arribat aquest punt, s'obri una contrafinestra de la sala de cria i es disposa una font d'aliment (una barreja de sucres, aigua i agar) per atraure els adults, que s'arreplegaran amb un pinzell i un pot. La quantitat d'adults arreplegats es calcula per volumetria amb un tub graduat. Finalment els adults s'introdueixen en gots de cartó, on s'afegeix el mateix tipus d'aliment a la tapa (figura 9).

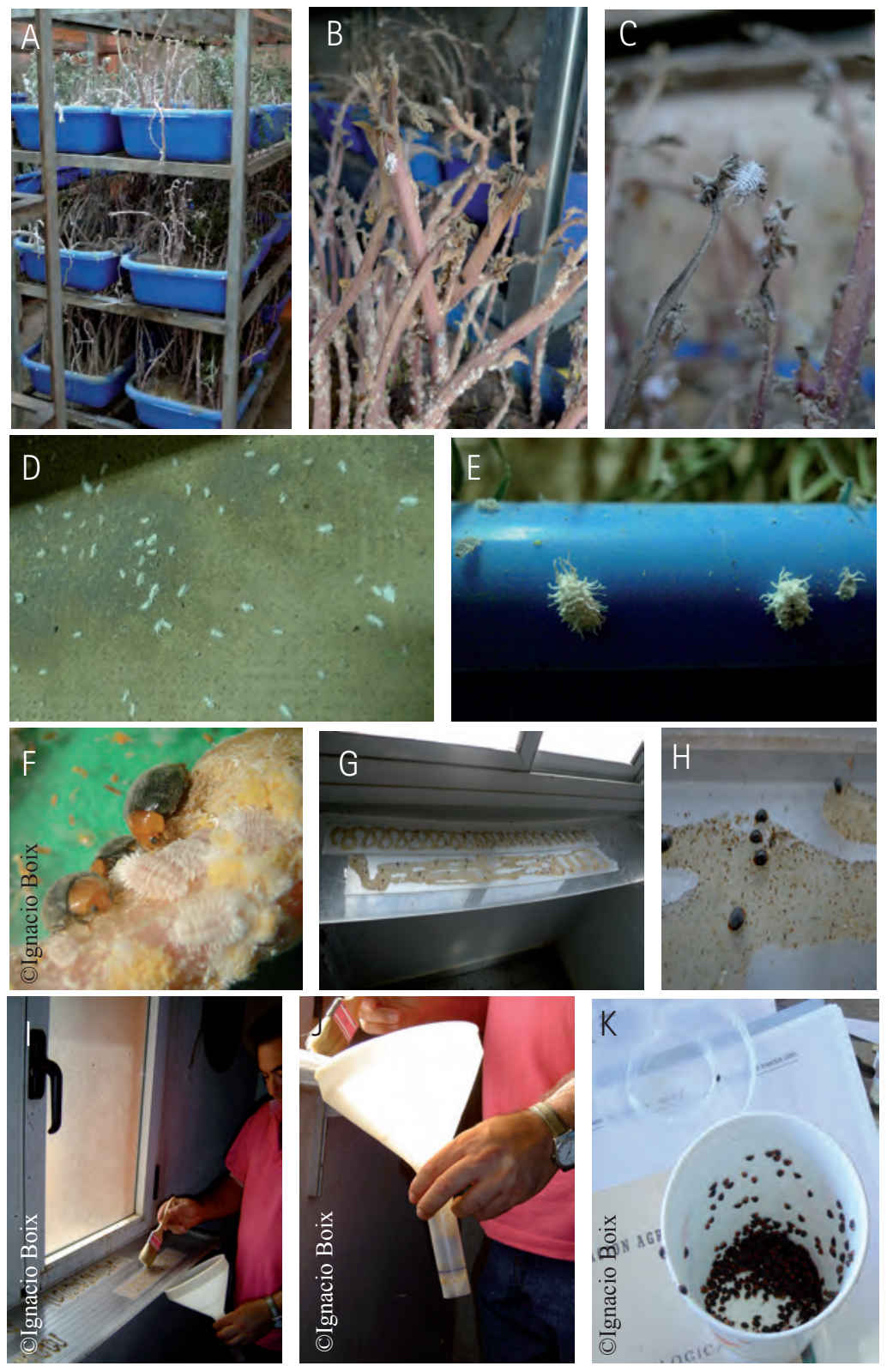

Figura 9. Cria de Cryptolaemus montrouzieri. A) Safates amb cotonet i larves de C. montrouzieri. B), C), D) i E) larves de C. montrouzieri; F) adults depredant nimfes de cotonet; G) tira de plàstic amb la dieta disposada sota la finestra per atraure als adults; H) adults alimentant-se de la dieta; I) arreplegada dels adults; J) mesura volumètrica del nombre d'adults; K) gots de cartó amb els adults preparats per ser alliberats 


\subsubsection{Cotxinilla acanalada, Icerya purchasi}

Per al control d'aquesta plaga, l'insectari d'Almassora ha posat a punt la cria d'un depredador coccinèl·lid (taula 5).

\begin{tabular}{|c|c|c|c|c|c|}
\hline Enemic natural & Ordre & Família & $\begin{array}{c}\text { Comportament } \\
\text { biològic }\end{array}$ & Planta hoste & $\begin{array}{c}\text { Artròpode } \\
\text { hoste }\end{array}$ \\
\hline Rodolia cardinalis & Coleoptera & Coccinellidae & Depredador & Pittosporum tobira & Icerya purchasi \\
\hline
\end{tabular}

Taula 5. Característiques principals de l'enemic natural d'I. purchasi

La cria de $R$. cardinalis es va iniciar a l'Estació Agrícola de Burjassot a principis del segle xx amb individus procedents de França i de Portugal. Més tard, al voltant dels anys 50, quan s'observà com s'aclimataven als nostres camps, es va deixar de criar, fins als anys 80 que, com a conseqüència dels tractaments amb plaguicides tòxics per aquest coccinèl-lid, se'n va haver de tornar a reactivar la cria per la ressurgència de la cotxinilla acanalada.

\section{Cria de la cotxinilla acanalada, Icerya purchasi}

Com a planta hoste per a la cria d'I. purchasi s'empren plantes d'uns $50 \mathrm{~cm}$ d'alçada de l'espècie Pittosporum tobira (Thunb.). Aquestes plantes es compren a vivers especialitzats i s'emmagatzemen en hivernacles aclimatats fins al moment de la infestació.

La infestació es realitza agafant brots amb femelles adultes i nimfes de la cotxinilla $\mathrm{i}$ introduint-los en pots de plàstic que es fixen a la planta mitjançant un fil d'aram. Les nimfes ixen del pot i busquen la nova superfície per fixar-se i reproduir-se. Quan les cotxinilles arriben a l'estadi adequat, les plantes es traslladen a la càmera de cria del depredador (figura 10). 

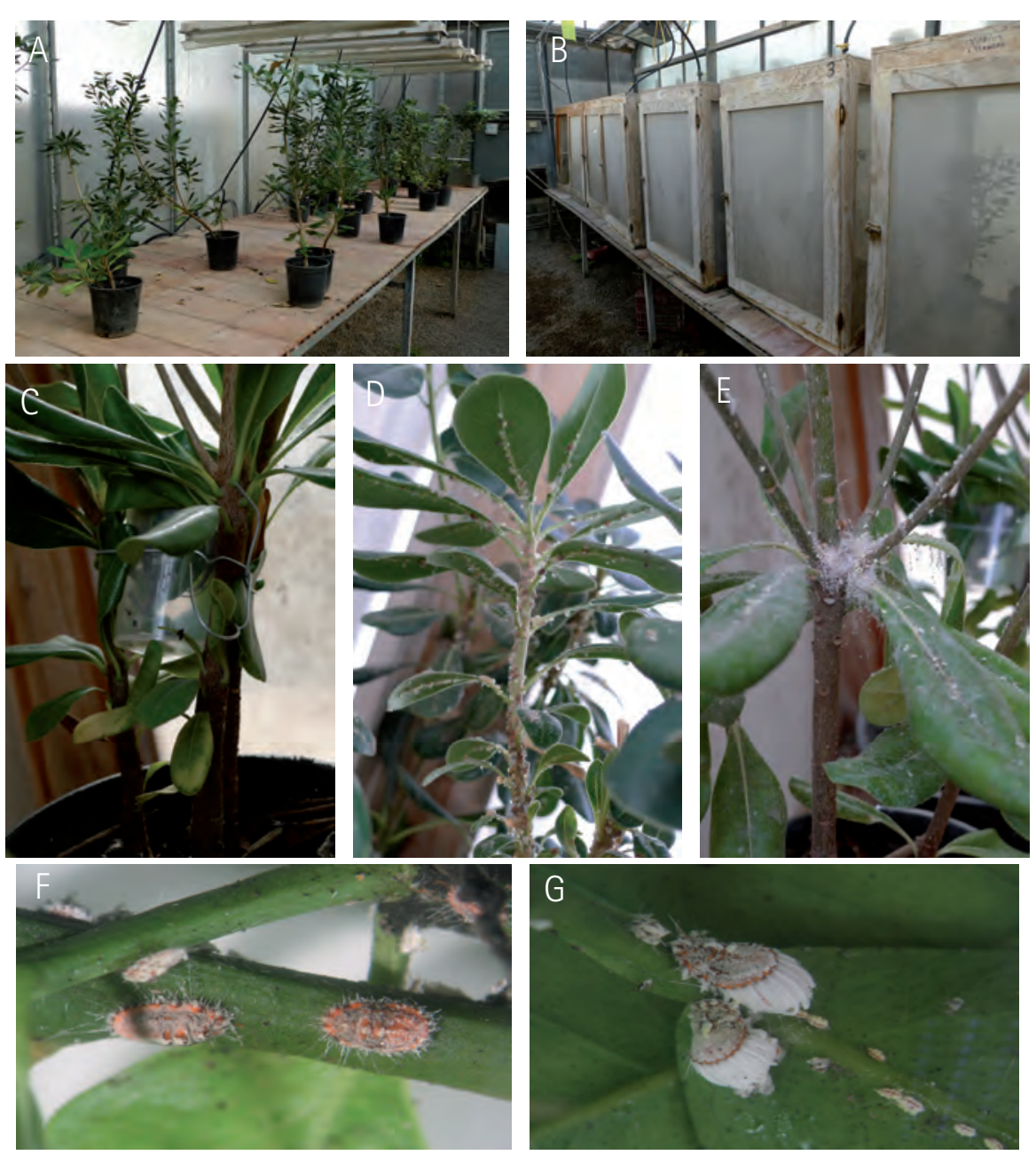

Figura 10. Cria d'Icerya purchasi. A) Plantes de Pittosporum tobira a l'hivernacle de plantes; B) gàbies condicionades per a la cria d'I. purchasi; C) pot de plàstic fixat a la planta amb cotxinilles amb nimfes a l'interior del sac ovíger; D), E) i F) diferents estadis de la cotxinilla acanalada on es poden observar els fils de melassa que produeixen; G) femelles adultes amb el sac ovíger format

\section{Cria del depredador Rodolia cardinalis}

Les plantes infestades es traslladen a evolucionaris ventilats i tancats on s'alliberen els adults del coccinèl-lid depredador. En general, per cada 24 plantes infestades amb cotxinilles en l'estadi adequat s'amollen 20 adults de $R$. cardinalis. Al voltant del mes, apareixen els primers adults, que s'arrepleguen amb aspiradors manuals i es passen a noves gàbies o als receptacles de cartó o plàstic, des d'on s'alliberaran en camp. Als recipients de solta s'afegirà paper parafinat amb unes gotetes de mel per millorar el manteniment dels adults (figura 11). 

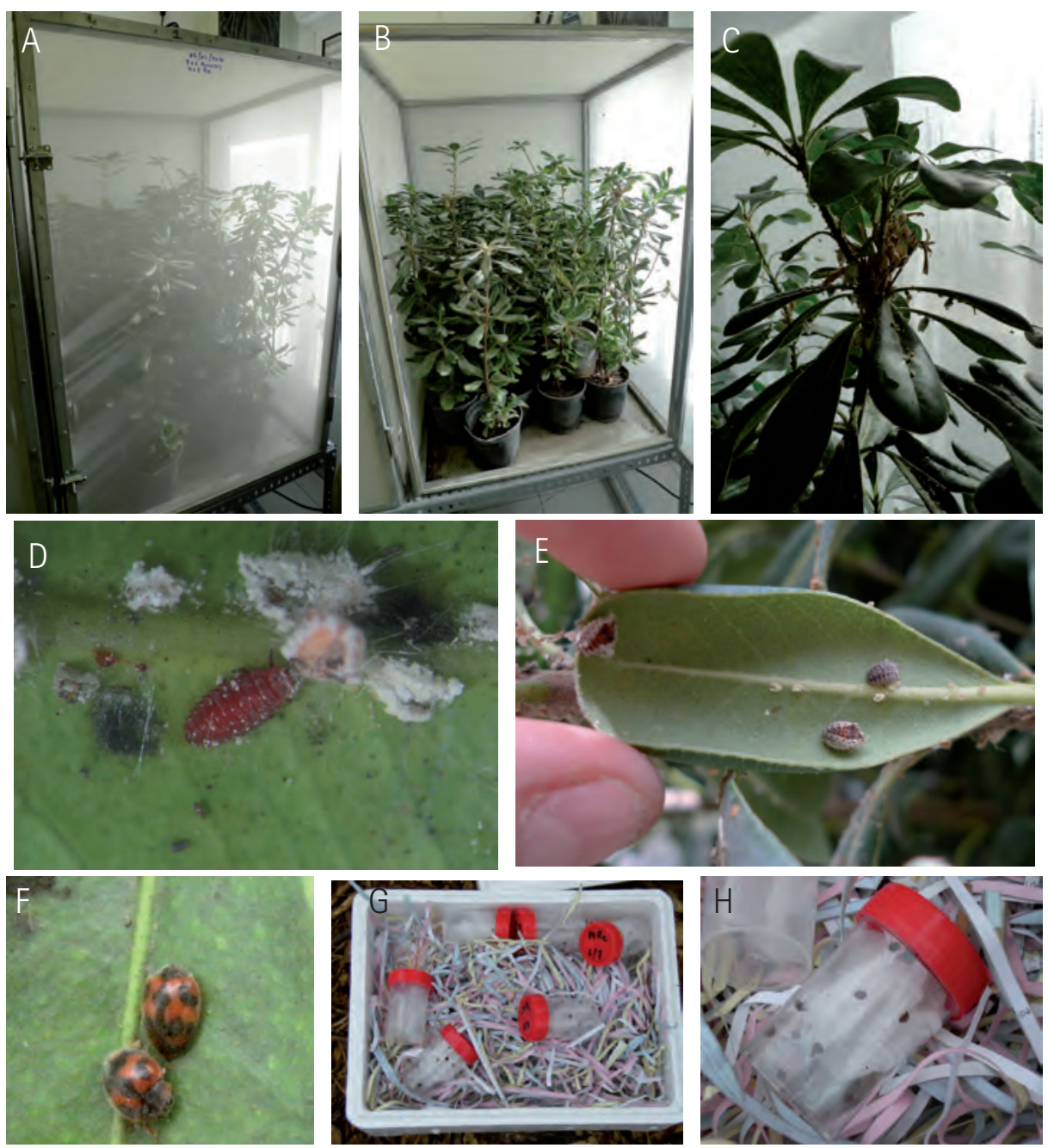

Figura 11. Cria de Rodolia cardinalis. A), B) i C) Plantes de Pittosporum tobira infestades amb la cotxinilla acanalada i amb adults de $R$. cardinalis; D) larva de $R$. cardinalis alimentant-se de la cotxinilla acanalada; E) pupes i F) adults de $R$. cardinalis; G) caixa amb els pots preparada per a la solta; $\mathrm{H}$ ) detall d'un pot de solta amb els adults i les tires de paper parafinat amb mel a l'interior

\subsubsection{Poll roig de Califòrnia, Aonidiella aurantii}

Per al control d'aquesta plaga l'insectari d'Almassora ha posat a punt la cria de quatre parasitoides himenòpters amb diferents tipus de desenvolupament $\mathrm{i}$ un depredador coccinèlllid. A la taula $6 \mathrm{~s}$ 'exposen les característiques d'aquests i es fa menció a la planta hoste i a l'artròpode sobre el qual el reprodueixen. 


\begin{tabular}{|l|l|l|l|l|l|}
\hline \multicolumn{1}{|c|}{ Enemic natural } & \multicolumn{1}{|c|}{ Ordre } & Família & $\begin{array}{c}\text { Comportament } \\
\text { biològic }\end{array}$ & $\begin{array}{c}\text { Planta } \\
\text { hoste }\end{array}$ & Artròpode hoste \\
\hline Aphytis melinus & Hymenoptera & Aphelinidae & Ectoparasitoide & Carabassa & Aspidiotus nerii \\
\hline Aphytis lingnanensis & Hymenoptera & Aphelinidae & Ectoparasitoide & Carabassa & Aspidiotus nerii \\
\hline Encarsia perniciosi & Hymenoptera & Aphelinidae & Endoparasitoide & $\begin{array}{l}\text { Carabassa } \\
\text { Llima }\end{array}$ & Aonidiella aurantii \\
\hline Comperiella bifasciata & Hymenoptera & Encyrtidae & Endoparasitoide & $\begin{array}{l}\text { Carabassa } \\
\text { Llima }\end{array}$ & Aonidiella aurantii \\
\hline Rhyzobius lophantae & Coleoptera & Coccinellidae & Depredador & Carabassa & Aspidiotus nerii \\
\hline
\end{tabular}

Taula 6. Principals característiques dels enemics naturals d'A. aurantii

La cria d'A. melinus es va iniciar en $1975 \mathrm{amb}$ individus procedents de la Estació de Zoologia i Lluita Biològica d'Antíbol (França), on es criaven sobre el poll blanc, Aspidiotus nerii Bouche. L'inici de la cria d'A. lingnanensis va coincidir amb de la recerca d'enemics naturals del minador Phyllocnistis citrella Stainton, en 1995, realitzada a Austràlia. La cria d'E. perniciosi i C. bifasciata es va iniciar al voltant de 2003, gràcies a la transferència d'aquests enemics naturals des del laboratori d'Entomologia de l'Institut Valencià d'Investigacions Agràries. La procedència d'aquests dos enemics naturals era Califòrnia (Pina, 2006). Per acabar, $R$. lophantae va començar a criar-se molt recentment, el 2008, i encara està en procés de millora.

\section{Cria de les cotxinilles Aonidiella aurantii i Aspidiotus nerii en carabassa}

El substrat vegetal que en l'actualitat s'empra a Almassora per a la cria de les cotxinilles és la carabassa de cacauet (Cucurbita moschata Duchesne). Aquestes carabasses es conserven molt bé, i aguanten en bon estat pràcticament tot l'any. Les carabasses, abans d'emprar-les, es netegen amb aigua i raspall i es deixen eixugar.

A continuació, passen a una sala tancada on s'infesten amb la cotxinilla hoste que, segons l'enemic natural que es vaja a criar posteriorment, és $A$. nerii o $A$. aurantii. Per a la cria d'aquests diaspídids es reprodueix la tècnica de la línia d'ombra descrita per DeBach i White (1960) amb algunes modificacions. En aquest mètode es disposa la carabassa prèviament infestada amb cotxinilles que ja han arribat a l'estadi de producció de nimfes, en una sala a les fosques amb un únic punt de llum que s'hi disposa al davant. Les nimfes es desplacen per la superfície buscant el punt de màxima intensitat lumínica fins a arribar a l'extrem final de la carabassa; des d'açí cauen sobre la carabassa que es vol infestar o sobre una superfície disposada en la base, per on continuen caminant fins a parar-se en una línia d'ombra. En aquest punt d'ombra s'arrepleguen, s'introdueixen en un pot amb una fina malla com a tapa i s'espolsen com si foren sal damunt la superfície que es vol infestar. A continuació les carabasses infestades es porten a una altra habitació en completa obscuritat perquè es desenvolupen les cotxinilles fins que arriben als estadis adequats de ser parasitades o perquè servisquen com a cotxinilles productores de nimfes (figura 12). 

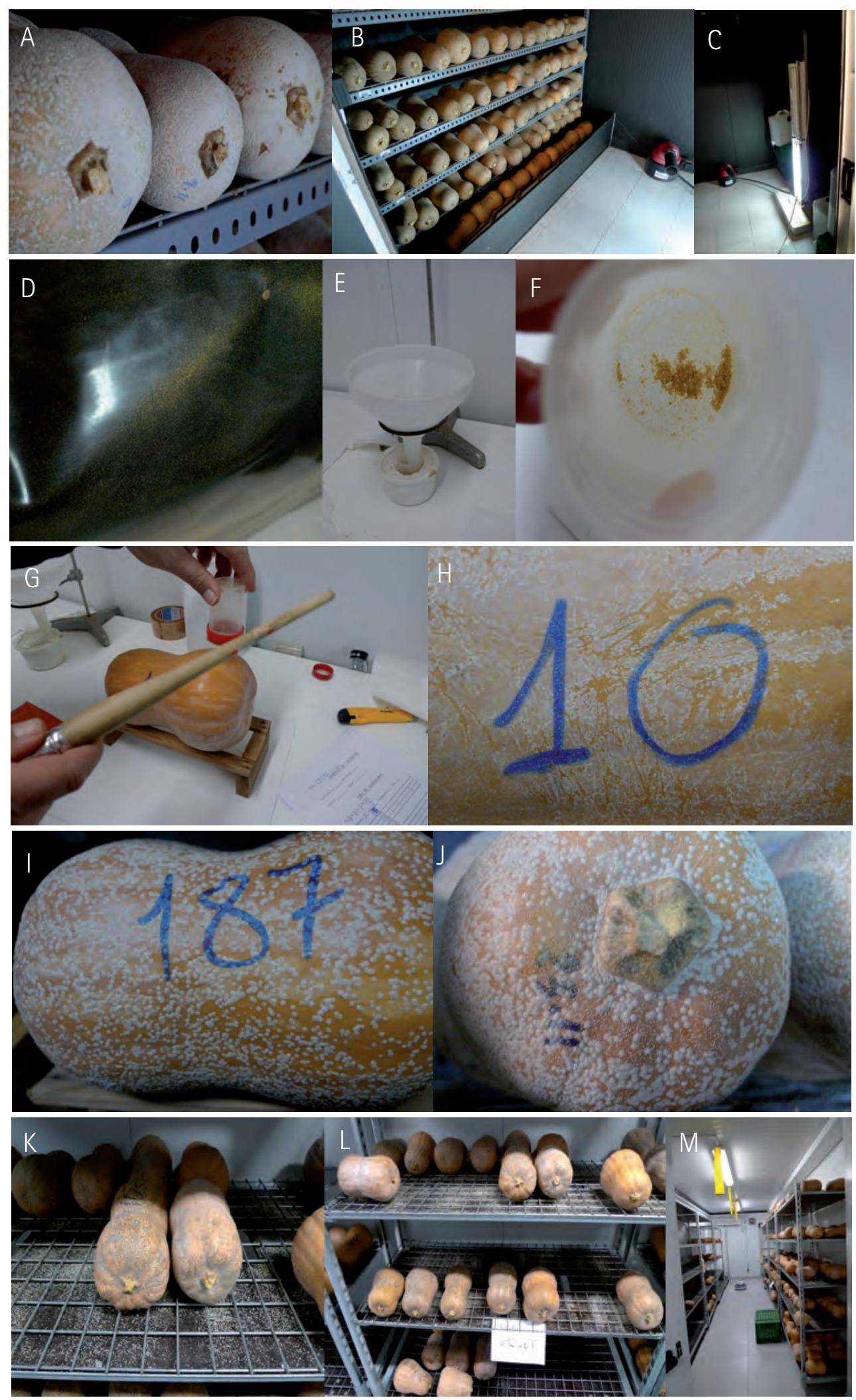

Figura 12. Cria de les cotxinilles Aonidiella aurantii i Aspidiotus nerii. A) Carabassa amb cotxinilles en l'estadi de femelles gràvides productores de nimfes; B) disposició de les carabasses. A la fila inferior es col-loca la carabassa que es vol infestar; C) punt de llum; D) nimfes de cotxinilles damunt d'una superfície col·lectora; E) embut mitjançant el qual s'arrepleguen les nimfes que han caigut a la superfície; F) nimfes arreplegades a l'interior del pot; G) «salat» de la cotxinilla; H), I) i J) diferents estadis de les cotxinilles; K), L) i M) sala d'emmagatzemament de les carabasses infestades 


\section{Cria de la cotxinilla Aonidiella aurantii en llima}

La cria d'Aonidiella aurantii sobre carabassa està en un procés continu de millora, i fins que es trobe el punt òptim la crien també sobre llima verda. La cria sobre aquest substrat presenta l'avantatge que és fàcilment manipulable, però té nombrosos desavantatges, com la dificultat de trobar-la al llarg de tot l'any, el fet de ser un substrat car d'adquirir i que no es conserva bé. El mecanisme de cria en aquest cas és completament diferent. Les cotxinilles productores de nimfes es col·loquen baix i les nimfes, en lloc de caure, pugen per uns tubs de cartó negre atretes per una font de llum situada en un plànol superior i pel seu propi geotropisme negatiu. Les llimes ja infestades es col-loquen dins de recipients fins que arribe el moment d'emprar-les com a cotxinilles productores de nimfes o com a cotxinilles hoste (figura 13).
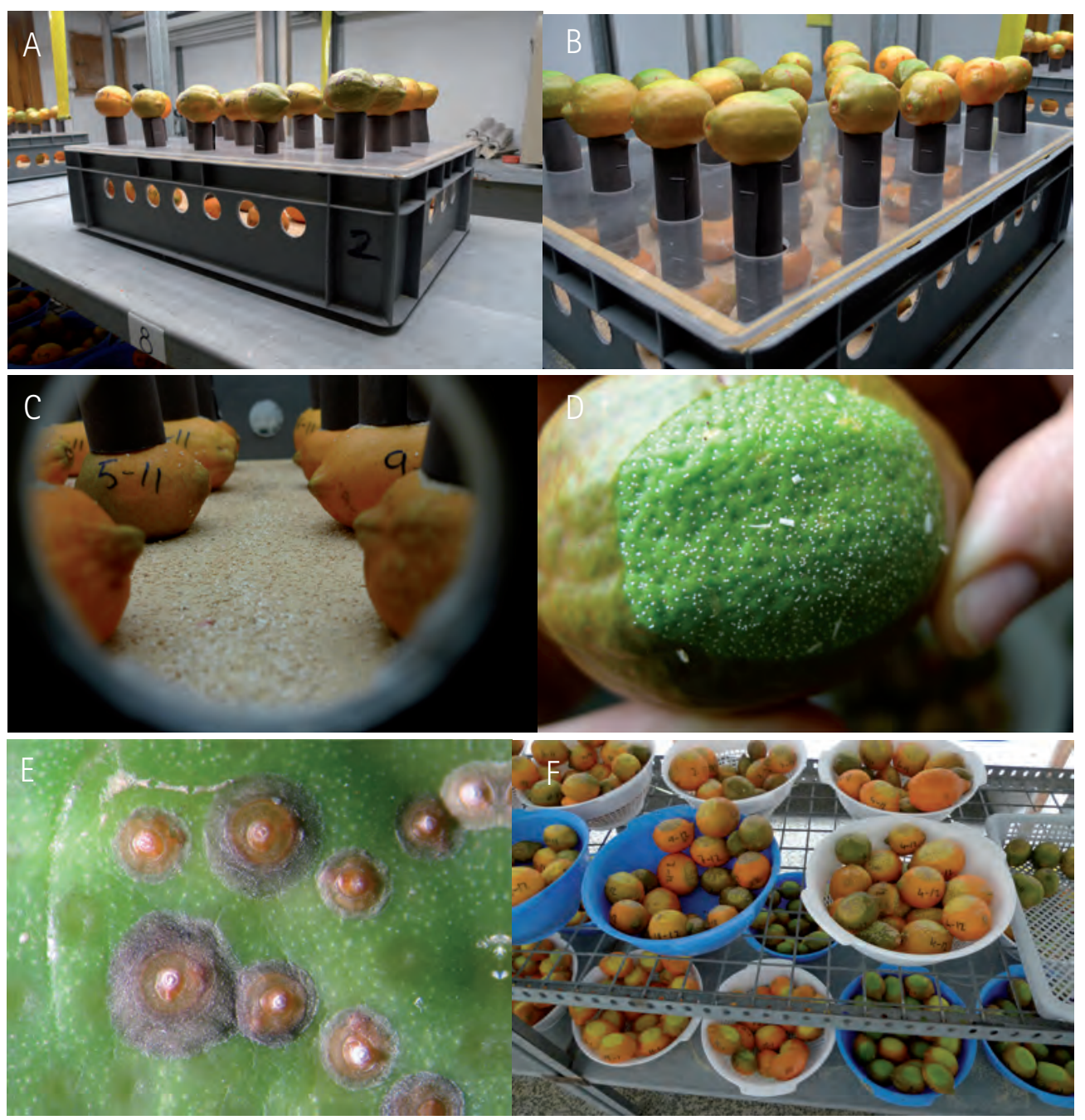

Figura 13. Cria d'Aonidiella aurantii sobre llima. A), B) i C) Caixes emprades per la infestació de noves llimes. Dins de la caixa es col-loquen les cotxinilles productores de nimfes i a la part superior les llimes que es volen infestar; D) llima amb les nimfes acabades de fixar; E) nimfes joves sobre llima; F) forma d'emmagatzemar les llimes 


\section{Cria dels parasitoides}

En funció del parasitoide que es vaja a produir i de l'espècie de la cotxinilla hoste, les cotxinilles han d'estar en un estadi o en un altre. Per a la cria de C. bifasciata, cal femelles adultes joves i femelles gràvides del poll roig de Califòrnia, mentre que E. perniciosi parasita primers i segons estadis nimfals, femelles joves i femelles gràvides d'aquesta mateixa cotxinilla. La cria d'Aphytis melinus i d'A. lingnanensis és mes senzilla perquè l'hoste emprat, $A$. nerii, degut al seu tipus de desenvolupament, està un període de temps major disponible per a ser parasitat (des de nimfa de segon estadi fins a femella gràvida) (figura 14).

Arribat el moment adequat del cicle de la cotxinilla, s'agafa la carabassa o la 1lima i s'introdueix dins d'unes caixes amb ventilació, alimentació (una barreja de sucres, aigua i agar) i carabasses o llimes amb cotxinilles ja parasitades i amb els adults dels parasitoides emergint. En aquestes caixes es mantenen les cotxinilles durant 48 hores perquè isquen els parasitoides de les carabasses ja parasitades $i$ parasiten aquestes cotxinilles acabades d'introduir. Posteriorment, els parasitoides s'adormen amb $\mathrm{CO}_{2}$, cauen en un paper situat a la base de la gàbia i s'introdueixen en un flascó graduat per mesurar per volum el nombre d'adults. Part d'aquests adults es reserven per a parasitar noves cotxinilles. Les carabasses noves ja parasitades es fiquen en una nova caixa fins que emergisquen els nous parasitoides i es puguen emprar per a noves soltes. Els adults que s'amollen al camp es posen en pots de plàstic amb una tira de paper parafinat amb gotetes de mel perquè arriben en bon estat nutricional (figura 15).

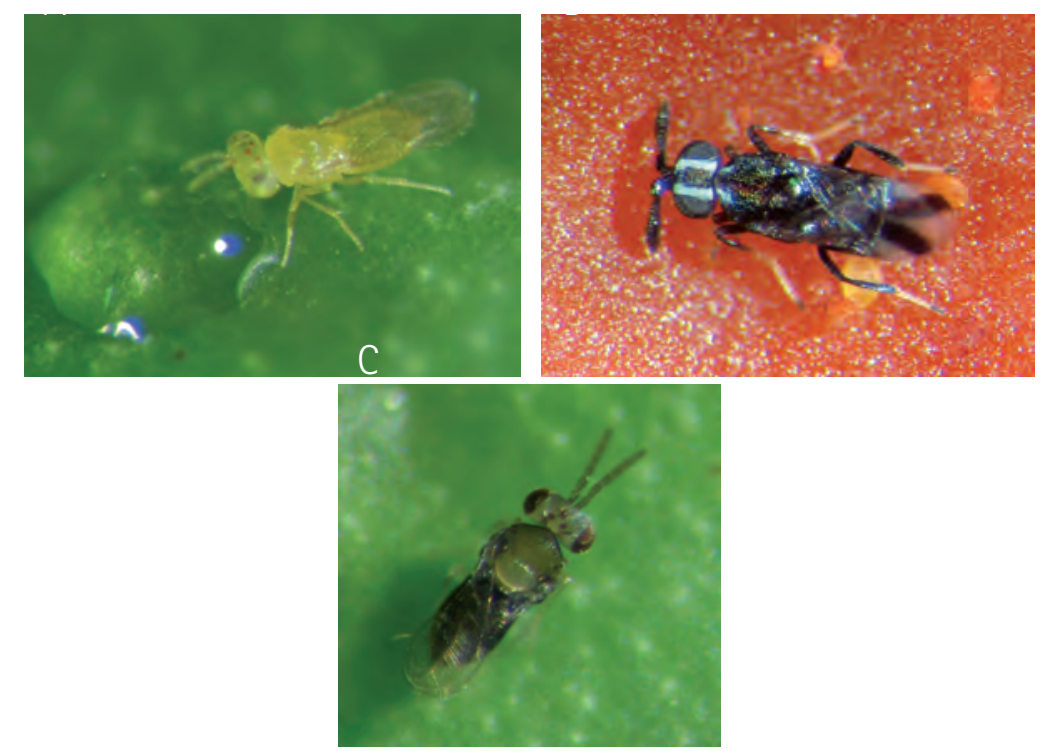

Figura 14. Adults d'Aphytis sp. (A); Comperiella bifasciata (B) i Encarsia perniciosi (C) 

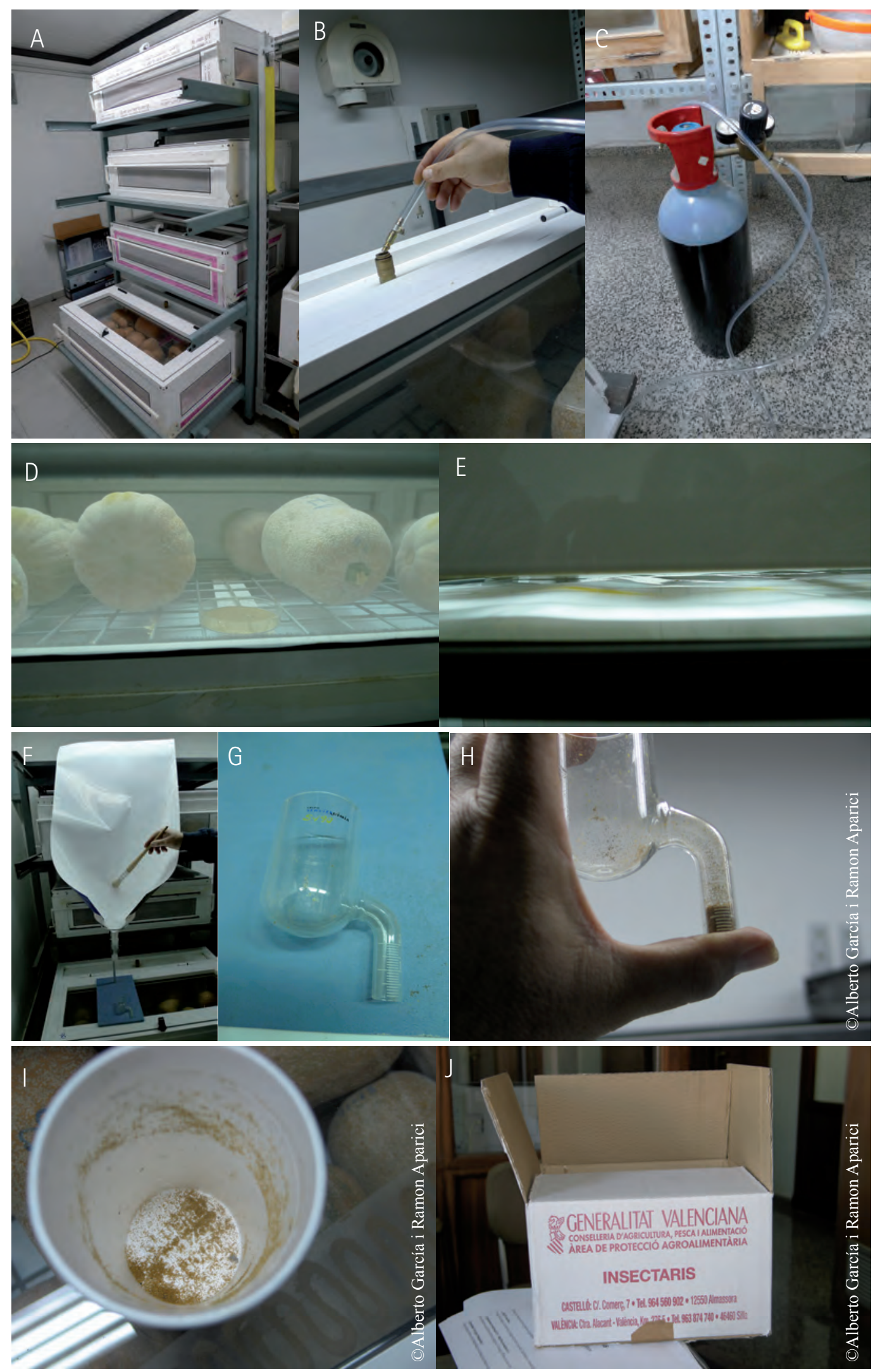

Figura 15. Cria dels parasitoides. A) Gàbies on es reprodueixen els parasitoides; B) tub per injectar el $\mathrm{CO}_{2}$; C) botella de $\mathrm{CO}_{2}$; D) vista lateral de la caixa on es veu el paper en què s'arrepleguen els parasitoides; E) detall del paper amb els adults abans de retirar-lo; F), G) i H) mesura volumètrica dels adults; I) pot de solta; J) caixa per distribuir els enemics naturals amb el segell oficial de la Generalitat Valenciana 


\section{Cria del depredador Rhyzobius lophantae}

La cria d'aquest depredador es fa en l'actualitat sobre $A$. nerii, si be s'està plantejant fer-la sobre $A$. aurantii una vegada aconseguisquen un bon sistema de cria d'aquest diaspídid.

Per a la cria, s'ofereixen al coccinèl-lid diferents estadis de la cotxinilla perquè s'alimente i faça la posta (normalment sota l'escut). La larva de $R$. lophantae també és depredadora de cotxinilles, sobretot d'estadis immadurs. Quan la pupació està pròxima s'inclouen a la gàbia bocins de cotó en pèl perquè la larva, si es deixa caure a terra, tinga un lloc on pupar.

Una vegada ixen els adults, una part s'aspira i s'introdueix en pots amb alimentació fins que arribe el moment de la solta, mentre que una altra part es deixa perquè continue reproduint-se (figura 16).
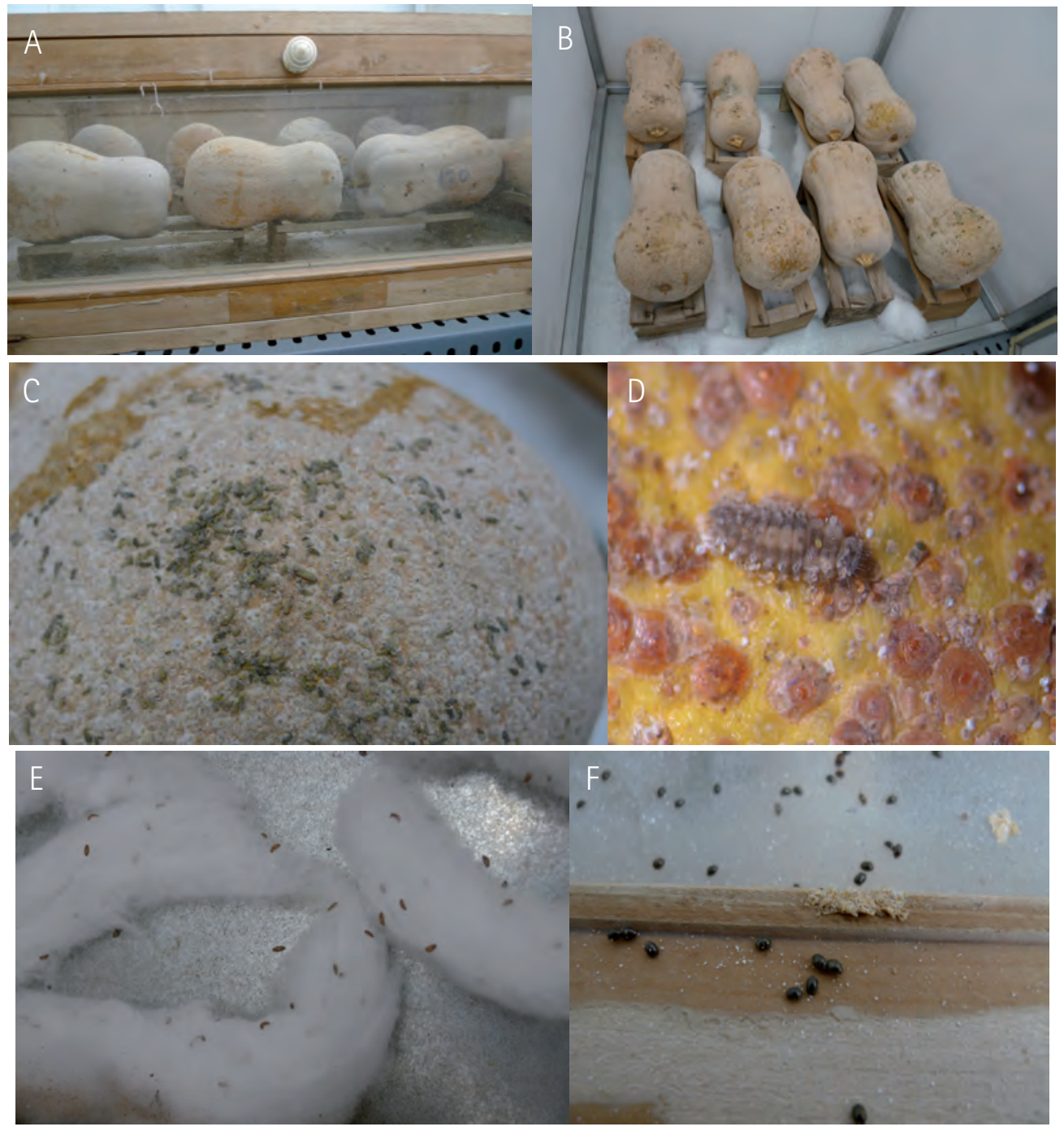

Figura 16. Cria de Rhyzobius lophantae. A) Gàbies on es reprodueix el depredador; B) disposició de les carabasses amb les cotxinilles; C) larves de $R$. lophantae alimentant-se de les cotxinilles; D) detall d'una larva nodrint-se, en aquest cas d'A. aurantii;

E) larves a punt de pupar en el cotó en pèl; F) adults de $R$. lophantae 


\section{Objectius de la pràctica}

Els objectius d'aquesta pràctica es concreten en :

1. Conèixer el funcionament d'un insectari.

2. Reconèixer els enemics naturals, tant depredadors com parasitoides, així com part de la seua biologia.

3. Observar la diversitat de plantes hoste, artròpodes hoste i enemics naturals emprats en aquest insectari.

\section{Desenvolupament de la pràctica}

\subsection{Material}

El material necessari per dur a terme aquesta pràctica és:

- Bloc de notes

- Bolígraf

- Càmera fotogràfica (opcional)

\subsection{Metodologia}

Una vegada arribats al insectari, el tècnic ens explicarà l'ordre de la visita per evitar contaminacions de les sales. Farem grups reduïts de 5 a 7 persones; cadascun anirà acompanyat per un tècnic. Cada grup veurà alguns dels passos de la cria d'aquests enemics naturals. L'objectiu és que cada grup prenga nota del que veja i li expliquen per posar en comú després la visita i ser capaços de completar la informació que s'ofereix en aquesta memòria. 


\section{Bibliografia}

Abad-Moyano, R., E. Aguilar i S. Pascual-Ruiz, (2009 a): «Control biológico de ácaros», en JACAS J. i A.URBANEJA, (ed.) (2009): Control biológico de plagas agrícolas, Valencia, Phytoma-España.

Abad-Moyano, R., T. Pina, O. Dembilio, F. Ferragut i A. Urbaneja (2009 b): «Survey of natural enemies of spider mites (Acari: Tetranychidae) in citrus orchards in eastern Spain», Experimental and Applied Acarology, 47, 49-61.

Аввотт, W. S. (1925): «A method of computing the effectiveness of an insecticide», Journal of Economic Entomology, 18, 265-267.

Agrios, G. N. (1997): Plant Pathology, (4 ${ }^{\mathrm{a}}$ ed.), San Diego, EuA, Academic Press.

Albajes, J. (2005): «Control biològic: del control clàssic a la conservació», en Jacas, J., P. CABAllero i J. Avilla (ed.) (2005): El control biológico de plagas y enfermedades. La sostenibilidad de la agricultura mediterránea, Castelló de la Plana, Universitat Jaume I, Universidad Pública de Navarra.

Aluja, M. (1993): Manejo Integrado de la mosca de la fruta, Mèxic D.F., Trillas. ANÒNIM (2002): «Ley 43/2002 de 20 de noviembre, de sanidad vegetal», BOE 21-11-2002.

APPSNET (2010): «American Phtyopathological Society Education Center», recurs digital disponible en: http://www.apsnet.org/education/top.html.

Argilés, R. i V. Tejedo (2007): «La lucha contra la mosca de la fruta mediante la técnica del insecto estéril en la Comunitat Valenciana», Levante Agrícola, Monografia C. capitata, 157-162.

Arneson, P. A. (2005): «Managing Potato Late Blight: Simulation with Lateblight», The Plant Health Instructor. DOI:10.1094/PHI/A-2005-0722-01, recurs digital disponible en: http://www.scientificsocieties.org/APS/Late_Blight/.

Aucejo-Romero, S., M. Foó, P. Ramis, P. Troncho, A. Gómez-Cadenas i J. A. JACAS-Miret (2003): «Evaluación de la eficacia de algunos acaricidas contra la araña roja, Tetranychus urticae Koch (Acari: Tetranychidae), en clementino», Boletín de Sanidad Vegetal. Plagas, 29, 453-459.

Aucejo-Romero, S., A. Gómez-Cadenas i J. A. Jacas-Miret (2004): «Effects of $\mathrm{NaCl}$-stressed citrus plants on life history parameters of Tetranychus urticae (Acari: Tetranychidae)», Experimental and Applied Acarology, 33, 55-68.

Avilla, J. (2005): «Agentes entomófagos de control biológico de plagas», en JACAS, J., P. CABAllero i J. Avilla (ed) (2005): El control biológico de plagas y enfermedades. La sostenibilidad de la agricultura mediterránea, Castelló de la Plana, Universitat Jaume I, Universidad Pública de Navarra.

BACHILlER-BACHILleR, P. i altres (1981): Plagas de insectos en las masas forestales españolas, Madrid, Ministerio de Agricultura, Pesca y Alimentación.

Bakri, A., K. Mehta i D. R. LANCE (2005): «Sterilizing insects with ionizing radiation» en Dyck, V. A., J. Hendrichs i A. S. Robinson (ed.) (2005): Sterile Insect Technique. Principles and Practice in Area-Wide Integrated Pest Management, Dordrecht, Springer.

BArr, D. B. i J. Angerer (2006): «Potential uses of biomonitoring data: a case study using the organophosphorus pesticides chlorpyrifos and malathion», Environmental Health Perspectives, 114(11), 1763-1769. 
Bellows, T. S. i T. W. Fisher (1999): Handbook of biological control, Londres, Academic Press.

Bisby, F. A., Y. R. Roskov, T. M. Orrell, D. Nicolson, L. E. Paglinawan, N. Bailly, P. M. Kirk, T. Bourgoin i G. Baillargeon (2012): «Species 2000 \& ITIS Catalogue of Life: 2012 Annual Checklist», recurs digital disponible en: www.catalogueoflife.org/annual-checklist/2012/. Species 2000: Reading, Regne Unit.

Blas, M. i altres (1987): «Artròpodes II» en R. Folch (ed.) (1986): Història Natural dels Països Catalans, Barcelona, Fundació Enciclopèdia Catalana.

Bovey, R. (1989): La defensa de las plantas cultivadas, Barcelona, Omega.

Brauer, F. (1885): «Systematische-zoologische Studien», Sitzungsberichteder (K.) Akademie der Wissenschaften in Wien, mathematische-naturwissenschaftlichen Klasse, 91, 237-431.

Bruhn, J. A., R. I. Bruck, W. E. Fry, P. A. Arneson i E. V. Keokosky (1980): Lateblight: A Disease Management Game. Computer program and manual, Department of Plant Pathology. Ithaca, Nova York, Cornell University Press.

Cabello García, T., M. Torres Gil i P. Barranco Vega (1997): Plagas de los cultivos: guía de identificación, Almeria, Universidad de Almería.

Chapman, A. D. (2009): «Number of living species in Australia and the world», recurs digital disponible en: http://www.environment.gov.au/biodiversity/abrs/ publications/other/species-numbers/2009/pubs/nlsaw-2nd-complete.pdf

Cohen, E., H. Podoler i M. El-Halauwi (1987): «Effects of the malathion-bait mixture used on citrus to control Ceratitis capitata (Wiedemann) (Diptera: Tephritidae) on the Florida red scale Chrysomphalus aonidium (L.) (Hemiptera: Diaspididae), and its parasitoid Aphytis holoxanthus DeBach (Hymenoptera: Aphelinidae)», Bulletin Entomological Research, 77, 303-307.

Cohen, E., H. Podoler i M. El-Hamlauwia (1988): «Effect of malathion-bait mixture on two parasitoids of the Florida red scale, Chrysomphalus aonidum (L.)», Crop Protection, 7(2), 91-95.

Crowson, R. A. (1981): The biology of Coleoptera, Nova York, Academic Press.

DaAne, K. M., D. L. Dahlsten i S. H. Dreistdt (1990): «Effects of Mediterranean fruit fly malathion bait spray on the longevity and oviposition of parasitoids of linden and tulip tree aphids (Homoptera: Aphididae)», Environmental Entomology, 19, 1130-1134.

DAVIES, R. G. (1991): Introducción a la entomología, Madrid, Mundiprensa.

DeBACH, P. i E. B. White (1960): Commercial mass culture of the California red scale parasite, University of California, Riverside, Division of Agricultural Science.

De LiÑan, C. (1998): Entomologia Agroforestal, Madrid, Ediciones Agrotécnicas S.L.

De Moraes, G. J. i C. H. W. Flechtmann (2008): Manual de Acarologia. Acarologia bàsica e ácaros de plantas cultivadas no Brasil, Ribeirão Preto, Holos Editora.

Del Río, M., L. Palou i J. A. Jacas (2008): «Tratamientos cuarentenarios de frutas», Infopost, 15 recurs digital disponible en: http://www.fomesa.com/Fruitech/boletines/INFOPOST\%2015.pdf.

Dyck, V. A., J. Hendrichs i A. S. Robinson (2005): Sterile Insect Technique: Principles and Practice in Area-Wide integrated pest management, els Països Baixos, Springer. 
Edwards, J. W., S. G. Lee, L. M. Heath i D. L. Pisaniello (2007): «Worker exposure and a risk assessment of malathion and fenthion used in the control of Mediterranean fruit fly in South Australia», Environmental Research, 103(1), 38-45.

EHLER, L. E. i P. C. ENDiCotT (1984): «Effect of malathion-bait sprays on biological control of insect pests of olive, citrus and walnut», Hilgardia, 52, 1-47.

EILENBERG, J., A. HAJEK i C. Lomer (2001): «Suggestions for unifying the terminology in biological control», BioControl, 46, 387-400.

ENCYClOPEDIA OF LifE (EoL), recurs digital disponible en: http://www.eol.org, últim accés, mars 2009.

EрPo (European and Mediterreanean Plant Protection Organization), recurs digital disponible en http://www.eppo.org/QUARANTINE/quarantine.htm.

- (1999): «Eppo standards. Safe use of biological control. First import of exotic biological control agents for research under contained conditions», recurs digital disponible en: http://archives.eppo.org/EPPOstandards/biocontrol.htm. Versió actualitzada a l'abril de 2010.

- (2000): «Eppo standards. Safe use of biological control. Import and release of exotic biological control agents», recurs digital disponible en: http://archives. eppo.org/EPPOStandards/biocontrol.htm. Versió actualitzada a l'abril de 2010.

- (2010): «Eppo standards. Safe use of biological control. List of biological control agents widely used in the EPPO region (web pages only)», recurs digital disponible en: http://archives.eppo.org/EPPOstandards/biocontrol.htm.

FAO (1996): «Codigo de conducta para la importación y liberación de agentes exoticos de control biológico», recurs digital disponible en: http://www.fao. org/WAICENT/FaoInfo/Agricult/AGP/PQ/Dwfault.html.

FAO/IAEA/USDA (2003): «Manual for Product Quality Control and Shipping Procedures for Sterile Mass-Reared Tephritid Fruit Flies Version 5.0», recurs digital disponible en: http://www.naweb.iaea.org/nafa/ipc/public/ipc-mass-reared-tephritid.html.

Fauna Europaea Web Service (2004): Fauna Europaea version 1.1, recurs digital disponible en: http://www.faunaeur.org.

Ferragut, F., F. Costa-Comelles, F. García-Marí, R. Laborda, D. Roca i C. Marzal (1988): «Dinámica poblacional del fitoseido Euseius stipulatus (Athias-Henriot) y su presa Panonychus citri (McGregor) (Acari: Phytoseiidae, Tetranychidae), en los cítricos españoles», Boletín de Sanidad Vegetal de Plagas, 14, 45-54.

Ferragut F.,I. Perez Moreno, V. Iraola, A. Escudero (2010): Ácaros depredadores en las plantas cultivadas. Familia Phytoseiidae, Madrid, Ediciones Agrotecnicas, S. L.

Fisher, T. W. i G. L. Finney (1964): «Insectary facilities and equipment», en DeBACH, P. (ed.) (1964): Biological control of insect pests and weeds, Nova York, Reinhold Publishing Corporation.

FINNEY G. L. i T. W. FISHER (1964): "Culture of entomophagous insects and their hosts», dins DeBAch, P. (ed.) (1964): Biological control of insect pests and weeds, Nova York, Reinhold Publishing Corporation.

Follett, P. A. i L. G. Neven (2006): «Current trends in quarantine entomology», Annual Review of Entomology, 51, 359- 385.

Fry, W. E., M. G. Milgroom, M. A. Doster, J. A. Bruhn i R. I. Bruck (1990): A plant disease management game, Lateblight version 3.1, Cornell University. 
García-Marí, F.; J. Costa-Comelles i F. Ferragut (1991): Ácaros de las plantas cultivadas y su control biológico, Alacant, Pisa.

Garcia-Maríí, F., F. Ferragut; J. Costa-Comelles; D. Roca; R. Laborda; C. Marzal (1987). Curso de Acarología agrícola. Escuela Técnica Superior de Ingenieros Agrónomos. València, Universidad Politécnica de Valencia.

Garrido Vivas, A. (1984): «Bioecología de Capnodis tenebrionis L. (Col., Bupresidae) y orientaciones para su control», Boletín del Servicio de Plagas, 10, 5-221.

Gerson, U. (1992): «Biology and control of the broad mite, Polyphagotarsonemus latus (Banks) (Acari: Tarsonemidae)», Experimental and Applied Acarology, 13, 163-168.

Gerson, U., R. L. Smiley i R. Ochoa (2003): Mites (acari) for pest control, Regne Unit, Blackwell Science Ltd.

Gillott, C. (2005): Entomology, Dordrecht, Springer.

Godfray, H. C. J. (1994): Parasitoids, Princeton, Princeton University Press.

Gullan, P. J. i P. S CRanston (1994): The insects: an outline of entomology, Londres, Chapman i Hall.

Hendrich, J., A. S. Robinson, J. P. Cayolc i W. Enkerlina (2002): «Medfly areawide sterile insect technique programmes for prevention, suppression or eradication: the importance of mating behavior studies», Florida Entomologist, 85(1), 1-13.

ICZN (1999): International code of zoological nomenclatures. Forth Edition. International Trust for Zoological Nomenclature, Londres.

Iturrondobeitia, C. B. (2004): «Àcaros» en Barrientos, J.A. (ed.) (2004): Curso práctico de entomología. Manuals de la Universitat Autònoma de Barcelona. Alicante, Bellaterra, Asociación Española de Entomología, Centro Iberoamericano de la Biodiversidad (CIBIO), Universitat Autònoma de Barcelona.

Jacas, J. A., A. Gómez Cadenas i A. Urbaneja (2001): «Situación actual del Manejo Integrado de Plagas en cítricos», Vida rural, juny, 33-36.

JacAs, J. A., A. URbaneja i J. L. Ripollés (2005): «El futuro del control biológico», en Jacas, J., P. CABAllero i J. Avilla (ed.) (2005): El control biológico de plagas y enfermedades. La sostenibilidad de la agricultura mediterránea, Castelló de la Plana, Universitat Jaume I, Universidad Pública de Navarra.

JaCAS, J. A. i A. URBANEJA (2009): «Tipos de control biológico y métodos para su implementación», en JACAS, J. i A. UrbaneJA (ed.) (2009): Control biológico de plagas agrícolas, Madrid, Phytoma España.

- (2010): «Biological control in citrus in Spain: from classical to conservation biological control», en Ciancio, A. i K. G. MukerJi (ed.) (2010): Integrated Management of Plant Pests and Diseases, Dordrecht, Springer.

Lauriault, L. M., D. C. Thompson, J. B. Pierce, G. J. Michels i W. V. Hamilton (2004): «Managing Aceria malherbae gall mites for control of field bindweed», Cooperative Extension Service, Circular 600, College of Agriculture and Home Economics, recurs digital disponible en: http://tucumcarisc.nmsu.edu/ documents/cr-600.pdf.

LinNÉ, K. Von (1735): Systema naturae, sive regna tria naturae systematica proposita per classes, ordines, genera et species, Leiden, Theodor Haak.

Luck, R. F., G. JiAnga i M. A.Houck (1999): "A laboratory evaluation of the astigmatid mite Hemisarcoptes cooremani Thomas (Acari: Hemisarcoptidae) as a potential biological control agent for an armored scale, Aonidiella 
aurantii (Maskell) (Homoptera: Diaspididae)», Biological Control, 15(2), 173-183.

Llorente Bousquets, J. (1990): La búsqueda del método natural, Mèxic, Fondo de Cultura Económica, S.A. De C. V.

MACKENZIE, D. R. (1981): «Scheduling fungicide applications for potato late blight with BliteCAST», Plant Disease, 65, 394-399.

Magaña, C., P. Hernández-Crespo, F. Ortego i P. Castañera (2007): «Resistance to malathion in field populations of Ceratitis capitata», Journal of Economic Entomology, 100(6), 1836-43.

Margulis, L. i K. V. Schwartz (1985): Cinco Reinos. Guía ilustrada de los phyla de la vida en la Tierra, Barcelona, Labor.

Marty, M. A., S. V. Dawson, M. A. Bradman, M. E. Harnly i M. J. Dibartolomeis (1994): «Assessment of exposure to malathion and malaoxon due to aerial application over urban areas of southern California», Journal of Exposure Analysis and Environmental Epidemiology, 4(1), 65-81.

MaYr, E. (1969): Principles of systematics zoology, Nova York, McGraw-Hill.

McMurtry, J. A. i B. A. Croft (1997): «Life-styles of phytoseiid mites and their role in biological control», Annual Review of Entomology, 42, 291-321.

Mellado, L. (1971): «La técnica de machos estériles en el control de la mosca del Mediterraneo: programas realizados en España», en Sterility principle for insect control or eradication, International atomic energy agency, STI/Pub./265, 49-54.

Mellado, L., D. J. NAdKL, M. Arroyo i A. Jimenez (1970): «Mediterranean fruit fly suppression experiment on the Spanish mainland in 1969. Sterile male technique for control of Fruit flies», Proc. Panel, Vienna, 1969, IAEA, 91.

Mellado, L., M. Arroyo i P. Ros (1974): «Control of Ceratitis capitata Wied. by the Sterile male Technique in Spain. The Sterile Insect Technique and its field application», Proc. Panel, Vienna, 1972, IAEA, 63.

Monzó, C., P. Vanaclocha, R. Outerelo, I. Ruiz-Tapiador, D. Tortosa, T. Pina i P. Castañera (2005): «Catalogación de especies de las familias Carabidae, Cicindelidae y Staphylinidae en el suelo de los cítricos de la provincia de Valencia, España», Boletín de Sanidad Vegetal. Plagas, 31, 483-492.

Muntañola, M. (1997): Guia dels fongs microscòpics, Barcelona, Pòrtic.

Nieto Nafría, J. M. i P. Mier Durante (1985): Tratado de entomología, Barcelona, Omega.

Ortego F., C. Magaña, P. Hernández-Crespo i P. Castañera (2005): «Detección de resistencia a insecticidas en Ceratitis capitata: bases bioquímicas y moleculares», Phytoma España, 173, 63-66.

Palou, L., M. A. DEl Rio i J. A. JaCAS (2007): «Aplicación en poscosecha de cítricos de tratamientos cuarentenarios contra la mosca mediterránea de la fruta», Levante Agrícola, Monografía C. capitata, 192-200.

PINA, T. (2006): Control biológico del piojo rojo de California, Aonidiella aurantii (Maskell) (Hemiptera; Diaspididae) y estrategias reproductivas de su principal enemigo natural Aphytis chrysomphali (Mercet) (Hymenoptera: Aphelinidae). Tesi doctoral, València, Universitat de València.

— (2009): «Insectos parasitoides», en JACAS, J. A. i A. UrbaneJA (ed.) (2009): Control biológico de plagas agrícolas, Madrid, Phytoma España. 
Pons, X. i M. Eizaguirre (2002): Prácticas de morfología de insectos y ácaros, Eines, 14, Lleida, Universitat de Lleida.

Primo-Millo, E., F. Alfaro i R. Argilés (2003): «Plan de actuación contra la mosca de las frutas (Ceratitis capitata) en la Comunidad Valenciana», Phytoma España, 153, 127-130.

PÜNTENER, W. (1981): Manual for field trials in plant protection, 2nd edition, Agricultural Division, Ciba-Geigy Limited.

Richard O. W. i R. G. Davis (1984): Tratado de entomología imms. Vol I y II, Barcelona, Omega.

Sabater-Muñoz B., V. San Andrés, A. Urbaneja i P. Castañera (2007): «Métodos moleculares para determinar la tasa de acoplamiento de los machos estériles de Ceratitis capitata en programas TIE», Levante Agrícola, Monografía C. capitata, 122-125.

Salgado, J. M., R. Outerello, P. Gamarra, M. Blas, X. Vazquez i J. C. OteRO (2004): «Coleòpteros» en BARRIENTOS, J.A. (ed.) (2004): Curso práctico de entomología. Manuals de la Universitat Autònoma de Barcelona. Alicante, Bellaterra, Asociación Española de Entomología, Centro Iberoamericano de la Biodiversidad (CIBIO), Universitat Autònoma de Barcelona.

Sammataro, D., U. Gerson i G. Needham (2000): «Parasitic mites of honey bees: life history, implications and impact», Annual Review of Entomology, 45, 519-548.

SAn Andrés, V., F. Ortego i V. Tejedo (2007 a): «Efecto de la radiación gamma sobre la actividad digestiva y longevidad de machos estériles de Ceratitis capitata», Levante Agrícola, Monografía C. capitata, 116-120.

San Andrés, V., A. Urbaneja, B. Sabater-Muñoz i P. Castañera (2007 b): «A novel molecular approach to assess mating success of sterile Ceratitis capitata (Diptera: Tephritidae) males in sterile insect technique programs», Journal of Economic Entomology, 100, 1444-1449.

SÁnchez-Ruiz, M., F. M Fontal-Cazalla, A. SÁnchez-Ruiz i J. I. López-Colón (1997): «El uso de insectos depredadores en el control biológico aplicado», Boletín de la Sociedad Entomológica Aragonesa, 20, 141-149.

Schumann, G. L. i C. J. D'ArCy (2000): «Late blight of potato and tomato. The Plant Health Instructor», DOI: 10.1094/PHI-I-2000-0724-01, recurs digital disponible en: http://www.apsnet.org/edcenter/intropp/lessons/fungi/oomycetes/ Pages/LateBlight.aspx.

Selfa Arlandis, J. i J. Pujade i Villar (2002): Fonaments de zoologia dels artròpodes, València, Universitat de València.

Siebold, C. T. W. Von i H. Stannius (1848): «Lehrbuch der vergleichenden Anatomie der wirbellosen Tiere». [Origen del nom Arthropoda, Berlín, Wilson i Doner, 1937].

Snodgrass, R. E. (1993): Principles of insect morphology, Ithaca, Nova York, Cornell University Press.

Thomas, M. C., J. B Heppner, R. E .Wooddruff, H. V. Weems, G. J. Steck i T. R. Fasulo (2007): «Mediterranean fruit fly, Ceratitis capitata (Wiedemann) (Insecta: Diptera: Tephritidae)», Universitat de Florida. EUA, recurs digital disponible en: http://edis.ifas.ufl.edu/in371.

Throne, J., D. K. Weaver, V. Chew i J. E. Baker (1995 a): «Probit analysis of correlated data: multiple observations over time at one concentration», Journal of Economic Entomology, 88(5), 1510-1512. 
Throne, J., D. K. Weaver i J. E. BAKer (1995 b): «Probit analysis: assessing goodness-of-fit based on backtransformations and residuals», Journal of Economic Entomology, 88(5), 1513-1516.

TROETsChleR, R. G. (1983): «Effects on nontarget arthropods of malathion bait sprays used in California to erradicate the mediterranean fruit fly, Ceratitis capitata (Wiedemann) (Diptera: Tephritidae)», Environmental Entomology, 12, 1816-1822.

Urbaneja, A., E. Llácer, O. Tomás, J. A. Jacas i A. Garrido (1999): «Effect of Temperature on Development and Survival of Cirrospilus sp. near lyncus (Hymenoptera: Eulophidae), Parasitoid of the Citrus Leafminer (Lepidoptera: Gracillariidae)», Environmental Entomology, 28, 339-344.

Urbaneja A., P. Castañera, D. Tortosa, O. Dembilio i E. Viñuela (2004): «Efectos secundarios de tratamientos cebo usados para el control de Ceratitis capitata, sobre fauna útil», Phytoma España, 160, 28-41.

Urbaneja, A., J. L. Ripollés, R. Abad, J. Calvo, P. Vanaclocha, J. A. Jacas i P. CASTAÑERA (2005): «Importancia de los artrópodos depredadores de insectos y ácaros en España», Boletin de Sanidad Vegetal de Plagas, 31, 209-223.

Urbaneja, A., F. García-Marí, D. Tortosa, C. Navarro, P. Vanaclocha, L. VarGUES i P. CASTAÑERA (2006): «Influence of ground predators on the survival of the Mediterranean fruit fly pupae, Ceratitis capitata, in Spanish citrus orchards», Biocontrol, 51, 611-626.

Van Lenteren, J. C. (2007): «Benefits of Biological Control. Rebeca Meeting. Invertebrate Biological Control Agents (Macrobials)», en www.rebeca-net.de/ Wageningen.

- (2003 a): Quality control and production of biological control agents. Theory and testing procedures, Regne Unit, CABI Publishing, Oxon.

— $(2003 b)$ : «Need for quality control of mass-produced biological control agents» dins VAN LENTEREN J.C. (ed.) (2003) Quality control and production of biological control agents. Theory and testing procedures, Regne Unit, CABI Publishing, Oxon.

- $(2003 c)$ : «Commercial availability of biological control agents» dins VAN LENTEREN J. C. (ed.) (2003) Quality control and production of biological control agents. Theory and testing procedures, Regne Unit, CABI Publishing. Oxon.

Van Lenteren, J. C. i M. G. Tommasini (2003): «Mass production, storage, shipment and release of natural enemies» dins VAN LENTEREN J. C. (ed.) (2003): Quality control and production of biological control agents. Theory and testing procedures, Regne Unit, CABI Publishing, Oxon.

VIÑUELA, E. (2005): «La lucha biológica, pieza clave de la agricultura sostenible», en JaCAs, J., P. CABAllero i J. Avilla (ed.) (2005): El control biológico de plagas y enfermedades. La sostenibilidad de la agricultura mediterránea, Castelló de la Plana, Universitat Jaume I, Universidad Pública de Navarra.

Viñuela, E., P. del Estal, M. Arroyo, A. Adán, F. Budia, J. Jacas i V. Marco (1992): Los artrópodos: características. Los insectos: órdenes. Monografía de la ETSIA, 128, Madrid, Universidad Politécnica de Madrid.

Viñuela, E., P. del Estal, M. Arroyo, A. AdÁn, F. Budia, J. Jacas, M. González i M. BAHENA (1996): Artrópodos: Insectos y ácaros. Monografia de la ETSIA, 154, Madrid, Universidad Politécnica de Madrid. 
Viñuela, E. i J. A. JaCAS (1998): «Los ácaros», en De LiÑÁn, C. (ed.) (1998): Entomología Agro-forestal. Insectos y ácaros que dañan montes, cultivos y jardines, Madrid, Ediciones Aerotécnicas S.L.

YeLA, J. L. (1997): «Insectos causantes de daños al patrimonio histórico y cultura: caracterización, tipos de daño y métodos de lucha (Arthropoda: Insecta)», Boletín de la Sociedad Entomológica Aragonesa, 20, 111-122. 